GABRIELA MARTINS REIS

\title{
DISTRIBUIÇÃO DE FUNGOS E FUMONISINAS E EXPRESSÃO DOS GENES FUM EM GRÃOS DE MILHO TRANSGÊNICO DA SEMEADURA À COLHEITA
}

Tese apresentada ao Programa de Pós-Graduação em Microbiologia do Instituto de Ciências Biomédicas da Universidade de São Paulo, para obtenção do título de Doutor em Ciências. 
GABRIELA MARTINS REIS

\author{
DISTRIBUIÇÃO DE FUNGOS E FUMONISINAS E \\ EXPRESSÃO DOS GENES FUM EM GRÃOS DE MILHO \\ TRANSGÊNICO DA SEMEADURA À COLHEITA
}

Tese apresentada ao Programa de Pós-Graduação em Microbiologia do Instituto de Ciências Biomédicas da Universidade de São Paulo, para obtenção do título de Doutor em Ciências.

Área de concentração: Microbiologia

Orientador: Prof. Dr. Benedito Corrêa

Versão original 
DADOS DE CATALOGAÇĀO NA PUBLICAÇĀO (CIP)

Serviço de Biblioteca e Informação Biomédica do

Instituto de Ciências Biomédicas da Universidade de São Paulo

reprodução não autorizada pelo autor

Reis, Gabriela Martins.

Distribuiçāo de fungos e fumonisinas e expressāo dos genes FUM em grāos de milho transgênico da semeadura à colheita / Gabriela Martins Reis. -- Sāo Paulo, 2014.

Orientador: Prof. Dr. Benedito Corrêa.

Tese (Doutorado) - Universidade de Sāo Paulo. Instituto de Ciências Biomédicas. Departamento de Microbiologia. Área de concentraçāo: Microbiologia. Linha de pesquisa: Micotoxinas e fungos toxigênicos.

Versāo do título para o inglês: Distribution of fungi and fumonisins and FUM genes expression in transgenic corn grains from sowing to harvest.

1. Fusarium verticillioides 2. Fumonisinas 3. Milho transgênico 4. Genes FUM 5. Fases de amadurecimento 6. qPCR I. Corrêa, Prof. Dr. Benedito II. Universidade de São Paulo. Instituto de Ciências Biomédicas. Programa de Pós-Graduaçāo em Microbiologia III. Título. 
Candidato (a):

Título da Tese:

Orientador (a):
Gabriela Martins Reis.

Distribuição de fungos e fumonisinas e expressão dos genes FUM em grãos de milho transgênico da semeadura à colheita.

A Comissão Julgadora dos Trabalhos de Defesa da Tese de Doutorado, em sessão pública realizada a considerou-o (a)
( ) Aprovado (a)
( ) Reprovado (a)

Examinador (a):

Assinatura:

Nome:

Instituição:

Examinador (a): $\quad$ Assinatura:

Nome:

Instituição:

Examinador (a): $\quad$ Assinatura:

Nome:

Instituição:

Examinador (a): $\quad$ Assinatura:

Nome:

Instituição:

Presidente:

Assinatura:

Nome:

Instituição: 


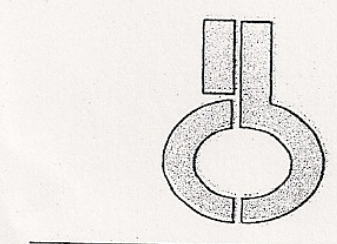

UNIVERSIDADE DE SÃO PAULO

INSTITUTO DE CIÊNCIAS BIOMÉDICAS

Cidade Universitária "Armando de Salles Oliveira"

Av. Prof. Lineu Prestes, 2415 - CEP. 05508-000 São Paulo, SP - Brasil

Telefone :(55) (11) 3091-7733 - telefax : (55) (11) 3091-8405

e-mail: sepolicb.usp. bx

\section{CERTIFICADO DE ISENÇÃO}

Certificamos que o Protocolo CEP-ICB N $N^{\circ} 430 / 10$ referente ao projeto intitulado: "Distribuição de fungos e fumonisinas e expressão dos genes FUM em grãos de milho transgênico da semeadura à colbeita" sob a responsabilidade de Gabriela Martins Reis, foi analisado na presente data pela CEUA - COMISSÃO DE ÉTICA NO USO DE ANIMAIS e pela CEPSH- COMISSÃO DE ÉTICA EM PESQUISA COM SERES HUMANOS, tendo sido deliberado que o referido projeto não envolve manipulação animal ou humana que justifique uma aprovação quanto aos princípios éticos exigidos por ambas as Comissões.

São Paulo, 23 de novembro de 2010.

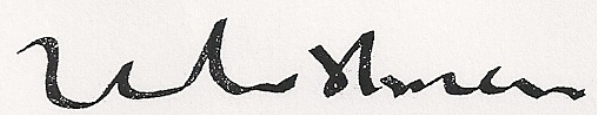

Prof. Dr. Wothan TAVARES DE LIMA Coordenador da CEUA - ICB/USP

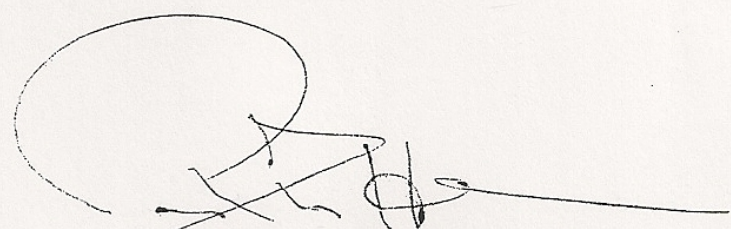

Prof. Dr. PaOlo M.A ZanotTo

Coordenador da CEPsh - ICB/USP 
Aos meus pais, Mario e Marcia, e ao meu marido Vinícios, por me apoiarem, durante estes anos de doutoramento, para que eu pudesse vencer mais essa importante etapa na vida. 


\section{AGRADECIMENTOS}

Em primeiro lugar, agradeço à Deus, por me dar a oportunidade, força e sabedoria para essa realização.

Agradeço ao Prof. Dr. Benedito Corrêa, por acreditar em mim, investir nesse trabalho e dedicar-se como orientador.

Faço um agradecimento muito especial à minha grande amiga, Liliana de Oliveira Rocha, que tanto me apoiou e me ajudou, fornecendo conhecimento e a verdadeira amizade a qualquer hora.

Ao Aildson Pereira Duarte, Edmilson e Rita do Apta do Médio Paranapanema, Tatiana Alves dos Reis e Liliana de Oliveira Rocha pelo apoio técnico e científico referente aos experimentos.

As minhas amigas, de laboratório e fora dele, Cynara, Lívia e Raquel por auxílios na pesquisa e por serem ouvidos nos momentos difíceis e felizes.

Aos meus colegas do Laboratório de Micotoxinas e Fungos Toxigênicos que, além dos conhecimentos científicos trocados, me ensinaram muito como conviver com as diferenças e respeitá-las.

Aos professores e alunos do Departamento de Microbiologia e do Instituto de Ciências Biomédicas da Universidade de São Paulo pelos conhecimentos transmitidos e auxílios prestados.

À Fundação de Amparo à Pesquisa do Estado de São Paulo (Fapesp) e ao Conselho Nacional de Desenvolvimento Científico e Tecnológico ( $\mathrm{CNPq}$ ) pelo apoio financeiro no desenvolvimento desse projeto, ao Instituto Agronômico de Campinas (IAC) e ao Apta Regional do Médio Paranapanema pelo apoio técnico para realização das coletas de milho e ao Inmet pelo fornecimento dos dados meteorológicos.

Ao Vinícios Duarte, meu marido, que suportou, principalmente na fase final do projeto, meu estresse, sempre me apoiando e me confortando com palavras de carinho.

Aos meus pais pelo suporte em todas as decisões tomadas na minha vida.

À todas as pessoas que, de alguma forma, fizeram parte e contribuíram de maneira positiva para a realização desse projeto e para meu próprio conhecimento. 
"A mente que se abre para uma nova ideia jamais voltará ao seu tamanho original." Albert Einstein 


\section{RESUMO}

REIS, G. M. Distribuição de fungos e fumonisinas e expressão dos genes $F U M$ em grãos de milho transgênico da semeadura à colheita. 2014. 117 f. Tese (Doutorado em Microbiologia) - Instituto de Ciências Biomédicas, Universidade de São Paulo, São Paulo, 2014.

Este estudo teve como objetivo geral avaliar a expressão dos genes $F U M$ como indicativo da contaminação por Fusarium verticillioides e da produção de fumonisinas nos grãos de milho durante o processo de amadurecimento dos grãos. Os objetivos específicos foram: identificar a micobiota e a contaminação por fumonisinas no milho transgênico, em diferentes períodos do desenvolvimento dos grãos no campo; determinar o potencial toxigênico dos isolados de $F$. verticillioides; verificar o perfil de expressão de 16 genes $F U M$ de $F$. verticillioides no milho; obter dendrograma filogenético através dos dados obtidos por sequenciamento parcial do gene $T E F-1 \alpha$ das cepas de $F$. verticillioides isoladas; comparar os resultados obtidos com os fatores climatológicos da região. $O$ isolamento dos fungos foi realizado pela técnica da semeadura direta, utilizando Ágar Dicloran Rosa Bengala Cloranfenicol, e a identificação, em nível de gênero, por métodos morfológicos clássicos. Entretanto, os fungos pertencentes ao gênero Fusarium foram identificados até espécie fazendo uso do sequenciamento parcial do gene do fator de elongação 1- $\alpha(T E F-1 \alpha)$. A determinação de fumonisinas foi realizada por Cromatografia Líquida de Alta Eficiência. Constatou-se contaminação fúngica em 100\% das amostras de milho, destacando-se o gênero Fusarium como o mais prevalente, com frequência variando de 3,85\% nas amostras do estádio de grão leitoso (R2) (coleta 2) a 100\% nas amostras no estádio de maturidade fisiológica (R6) (coleta 6). Dos isolados de Fusarium spp., $97 \%$ foram classificados como $F$. verticillioides. A presença de $\mathrm{FB}_{1} \mathrm{e} \mathrm{FB}_{2}$ foi registrada em $100 \%$ e em $18,41 \%$ das amostras, respectivamente. A amplificação de todos os genes FUM foi constatada em 123 (33,8\%) amostras de milho, com níveis de expressão de 3,88 (FUM16) a 7,65 (FUM13) (valores obtidos considerando a amostra calibradora). A totalidade dos isolados de $F$. verticillioides foram produtores de fumonisinas $\mathrm{B}_{1}$ e $\mathrm{B}_{2}$. Não foram constatadas correlações positivas entre a porcentagem de $F$. verticillioides, a produção de $\mathrm{FB}_{1}$ e $\mathrm{FB}_{2}$ e os fatores abióticos $(\mathrm{p}>0,05)$, o mesmo ocorrendo entre a expressão relativa dos genes $F U M$, os percentuais de isolamento de $F$. verticillioides e os níveis de contaminação por $\mathrm{FB}_{1}$ e $\mathrm{FB}_{2}(\mathrm{p}>0,05)$. Entretanto, constatou-se correlação positiva entre a probabilidade de amplificação dos genes $F U M$ e a fase de amadurecimento do grão, sendo a maior probabilidade atingida na fase de grão pastoso $(\mathrm{p}<0,05)$.

Palavras-chave: Fases de amadurecimento do grão. Fumonisinas. Fusarium verticillioides. Genes FUM. Milho transgênico. 


\begin{abstract}
REIS, G. M. Distribution of fungi and fumonisins and $F U M$ genes expression in transgenic corn grains from sowing to harvest. 2014. 117 p. Ph. D. thesis (Microbiology) Instituto de Ciências Biomédicas, Universidade de São Paulo, São Paulo, 2014.

This study evaluated the FUM gene expression in corn grains from sowing to harvest as evidence of Fusarium verticillioides contamination and fumonisins production. The specific objectives were: to identify the micobiota and fumonisin contamination in transgenic corn, in different periods of kernel maturation; to determine the toxigenic potential of $F$. verticillioides isolated strains; to verify the expression profile of $F U M$ gene cluster (16 genes) in corn, using quantitative PCR technique; to obtain the transcription elongation factor $1 \alpha(E F-1 \alpha)$ phylogenetic dendrogram for the isolated $F$. verticillioides strains and to compare the obtained data with the climatological factors of the harvesting region. For fungal isolation and identification, grains were seeded directly onto Dichloran-Rose Bengal Chloramphenicol Agar, followed by morphological characterization to the genus level. EF-1 $\alpha$ partial gene sequencing was used for Fusarium species confirmation. $\mathrm{FB}_{1}$ and $\mathrm{FB}_{2}$ extractions were performed using immunoaffinity column followed by high-performance liquid chromatography analysis. All samples were contaminated with fungi. The frequencies of Fusarium sp. ranged between 3,85\% (silking stage samples - R2) and 100\% (physiological maturity stage samples -R6). From 257 isolates, 97\% were identified as $F$. verticillioides. $\mathrm{FB}_{1}$ was detected in $100 \%$ of the samples and $\mathrm{FB}_{2}$ in $18,41 \%$. All FUM genes were expressed in 123 samples $(33,8 \%)$, the relative levels were variable in the samples from different harvest periods, with average ranging from 3.88 (FUM16) to 7.65 (FUM13), when compared to the calibrator sample. A $100 \%$ of the strains were able to produce $\mathrm{FB}_{1}$ and $\mathrm{FB}_{2}$. Positive correlation among the $F$. verticillioides isolation percentage, $\mathrm{FB}_{1}$ and $\mathrm{FB}_{2}$ production and the abiotic factors was not detected $(\mathrm{p}>0,05)$, positive correlation was also not detected among the FUM gene cluster relative expressions, $F$. verticillioides isolation percentage and $\mathrm{FB}_{1}$ and $\mathrm{FB}_{2}$ production $(\mathrm{p}>0,05)$. However, a positive correlation was detected between the probability of FUM gene expression and the kernel maturity stage with the highest probability achieved in kernel milk stage $-\mathrm{R} 3(\mathrm{p}<0,05)$.
\end{abstract}

Key-words: Kernel maturation stages. Fumonisins. Fusarium verticillioides. FUM gene cluster. Transgenic corn. 


\section{LISTA DE ILUSTRACÕES}

Figura 1 - Do teosinte ao milho moderno …….................................................. 14

Figura 2 - Estrutura anatômica e composição química do grão de milho ................. 15

Figura 3 - Estádios de desenvolvimento da cultura de milho ................................. 16

Figura 4 - $\quad$ Principais pragas do milho ....................................... 17

Figura 5 - $\quad$ Mecanismo de ação das proteínas Cry em insetos susceptíveis ............... 18

Figura 6 - Mecanismo de inserção de genes bacterianos em tecidos de plantas ...... 19

Figura 7 - $\quad$ Micromorfologia e macromorfologia de F. verticillioides ...................... 21

Figura 8 - Quadro comparativo de diferentes tipos de fumonisinas ...................... 23

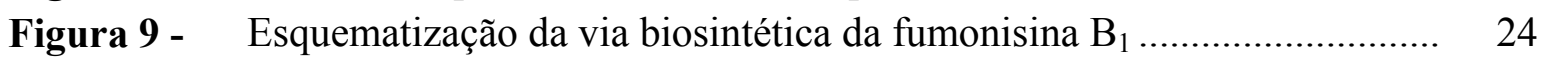

Figura 10- Frequência relativa (\%) de isolamento dos diferentes fungos em 52 amostras de grãos de milho da coleta 1 ................................................... 43

Figura 11- Frequência relativa (\%) de isolamento das diferentes espécies de Fusarium das amostras de grãos de milho das sete coletas.

Figura 12 - Frequência relativa (\%) de isolamento dos diferentes fungos em 52 amostras de grãos de milho da coleta 2 .................................................. 44

Figura 13 - Frequência relativa (\%) de isolamento dos diferentes fungos em 52 amostras de grãos de milho da coleta 3 ................................................. 45

Figura 14 - Frequência relativa (\%) de isolamento dos diferentes fungos em 52 amostras de grãos de milho da coleta 4 ................................................... 46

Figura 15- Frequência relativa (\%) de isolamento dos diferentes fungos em 52 amostras de grãos de milho da coleta 5 .

Figura 16 - Frequência relativa $(\%)$ de isolamento dos diferentes fungos em 52 amostras de grãos de milho da coleta 6 .

Figura 17 - Frequência relativa (\%) de isolamento dos diferentes fungos em 52

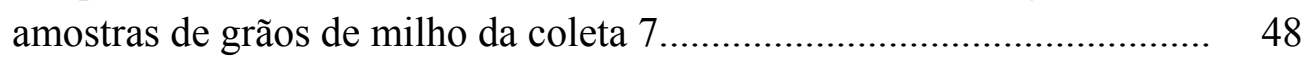

Figura 18 - Médias de $\mathrm{FB}_{1}(\mu \mathrm{g} / \mathrm{g})$ encontradas nas amostras de milho nas sete coletas.

Figura 19 - Médias de $\mathrm{FB}_{2}(\mu \mathrm{g} / \mathrm{g})$ encontrada nas amostras de milho nas sete coletas

Figura 20 - Curva de dissociação e perfil de amplificação do amplicon SPUD A obtidas na padronização do Ensaio SPUD .

Figura 21 - Perfil de amplificação e curva de dissociação do amplicon SPUD A obtidas no Ensaio SPUD das amostras

Figura 22 - Número de amostras que amplificaram todos os genes FUM estudados em cada coleta

Figura 23 - Expressão relativa média dos genes $F U M$ estudados nas diferentes coletas.

Figura 24 - Média da expressão relativa entre as 123 amostras qe amplificaram os genes FUM..

Figura 25 - Variação na expressão relativa média dos genes FUM nas 7 coletas....... 


\section{LISTA DE TABELAS}

Tabela 1 - Iniciadores utilizados para a realização da amplificação do cDNA na reação de qPCR

Tabela 2 - Iniciadores utilizados para a realização do Ensaio SPUD e sequência SPUD-

A

Tabela 3 - Valores médios das variáveis climatológicas

Tabela 4 - Concentração das fumonisinas $B_{1}$ e $B_{2}$ em 52 amostras de grãos de milho nas fases de florescimento, grão leitoso e grão pastoso .

Tabela 5 - Concentração das fumonisinas $B_{1}$ e $B_{2}$ em 52 amostras de grãos de milho nas fases de grão farináceo, grão farináceo-duro e grão em maturidade fisiológica.

Tabela 6 - Concentração das fumonisinas $B_{1}$ e $B_{2}$ em 52 amostras de grãos de milho na fase de colheita final.

Tabela 7 - Produção de fumonisinas pelas cepas de $F$. verticillioides isoladas de grãos de milho das fases de florescimento e grão leitoso.

Tabela 8 - Produção de fumonisinas pelas cepas de $F$. verticillioides isoladas de grãos de milho das fases de grão pastoso, grão farináceo e grão farináceo duro.

Tabela 9 - Produção de fumonisinas pelas cepas de $F$. verticillioides isoladas de grãos de milho das fases de maturidade fisiológica e colheita final.

Tabela 10 - Expressão relativa média dos genes $F U M$ para as diferentes coletas e a frequência relativa de isolamento de $F$. verticillioides nas respectivas coletas..

Tabela 11 - Estimativas e valores-p do ajuste do modelo de regressão beta binomial para a variável crescimento de $F$. verticillioides.

Tabela 12 - Valores-p das variáveis não incluídas no modelo de regressão beta binomial para a variável crescimento de $F$. verticillioides.

Tabela 13 - Estimativas e valores-p do ajuste do modelo de regressão Gaussiana Inversa para a variável produção de $\mathrm{FB}_{1}$.

Tabela 14 - Valores-p das variáveis não incluídas no modelo de regressão Gaussiana Inversa para a variável produção de $\mathrm{FB}_{1}$

Tabela 15 - Estimativas e valores-p do ajuste do modelo de regressão Gama inflacionado no zero para a variável produção de $\mathrm{FB}_{2}$...

Tabela 16 - Valores-p das variáveis não incluídas no modelo de regressão Gama inflacionado no zero para a variável produção de $\mathrm{FB}_{2}$

Tabela 17 - Valores-p das variáveis de valor da expressão dos genes FUM no modelo de regressão beta binomial inflacionado no zero para a variável crescimento de F. verticillioides.

Tabela 18 - Valores-p das variáveis de valor da expressão dos genes FUM no modelo de regressão Gaussiana Inversa para a variável produção de $\mathrm{FB}_{1}$.

Tabela 19 - Valores-p das variáveis de valor da expressão dos genes $F U M$ no modelo de regressão Gama inflacionado no zero para a variável produção de $\mathrm{FB}_{2}$......

Tabela 20 - Distribuição de frequências da variável amplificou ou não todos os genes FUM segmentada por fase de desenvolvimento do milho

Tabela 21 - Distribuição de frequências da variável amplificou ou não todos os genes FUM segmentada por faixa de valor da variável crescimento de $F$. verticillioides.

Tabela 22 - Valores-p das variáveis no modelo de regressão logística para a variável amplificou ou não todos os genes FUM.

Tabela 23 - Valores-p das comparações no modelo de regressão logística para a variável amplificou todos os genes $F U M$ 


\section{INTRODUCÃ̃}

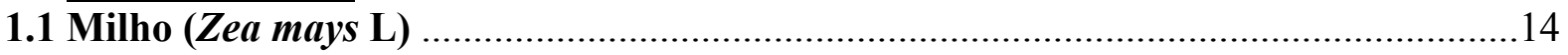

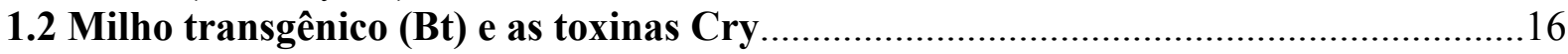

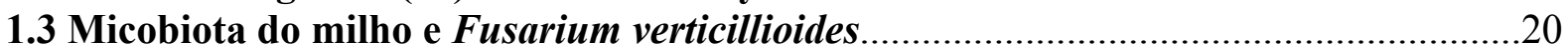

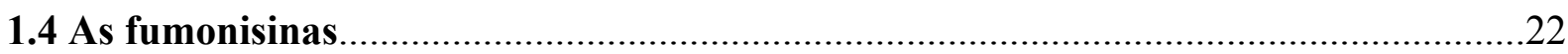

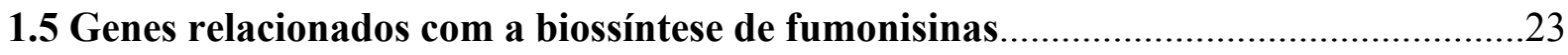

2 OBJETIVOS

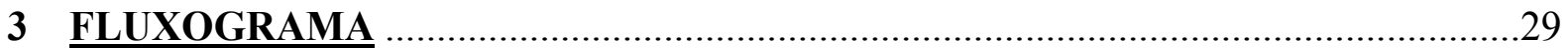

4 MATERIAIS E MÉTODOS

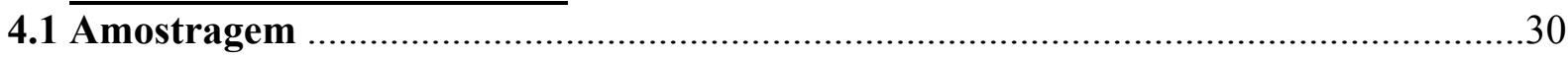

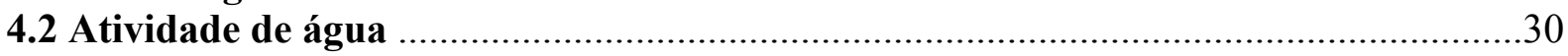

4.3 Micobiota das amostras de milho

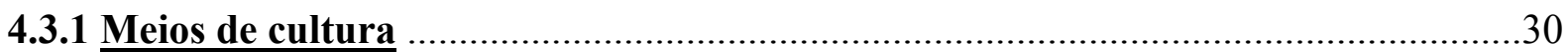

4.3.2 Técnica da semeadura direta para o isolamento da micobiota das amostras .........31

4.4 Identificação das espécies de Fusarium através do sequenciamento parcial de $T E F$ $1 \alpha$

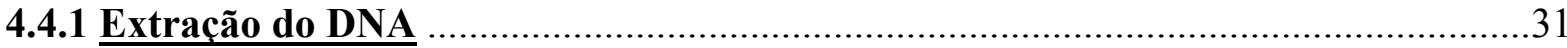

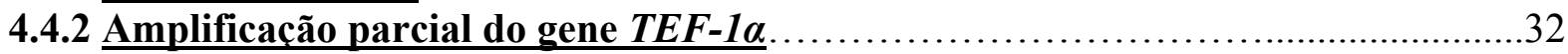

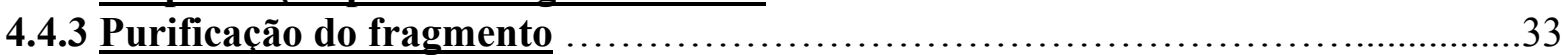

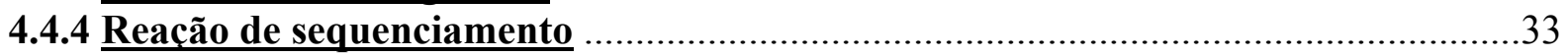

4.5 Análise filogenética das cepas de Fusarium verticillioides isoladas ...........................34

4.6 Determinação de fumonisinas nos grãos de milho

4.6.1 Extração e Purificação de fumonisinas das amostras ................................................34

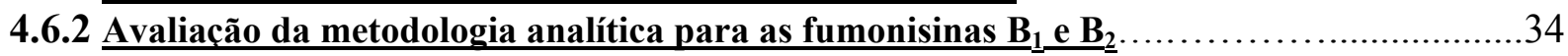

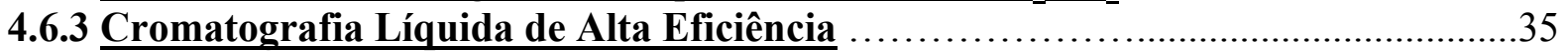

4.7 Avaliação do potencial toxigênico das cepas de $\boldsymbol{F}$. verticillioides isoladas ...................36

4.8 Análise da expressão dos genes $F U M$ em grãos de milho Bt por qPCR

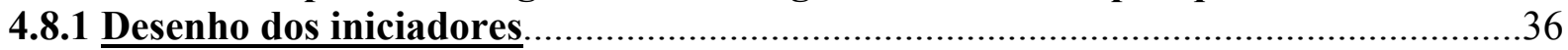

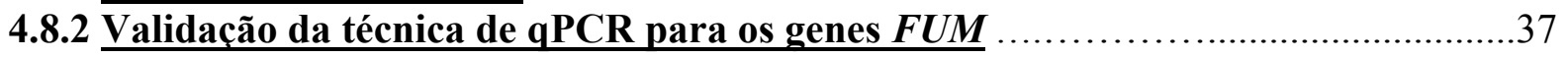

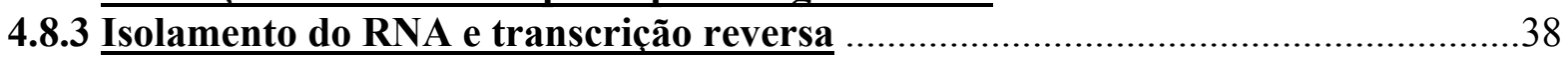

4.8.4 Ensaio SPUD para detecção de inibidores nas amostras de ácido nucléico .............38

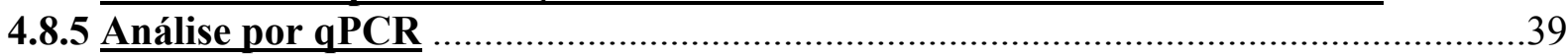

4.9 Análise dos Fatores Climatológicos nos períodos das diferentes coletas ...................40

4.10 Análises Estatísticas

4.10.1 Fase 1: Efeito das variáveis na porcentagem de isolamento de $F$. verticillioides e na contaminação por $\mathrm{FB}_{1}$ e $\mathrm{FB}_{2}$ nos grãos de milho

4.10.2 Fase 2: efeito do valor da expressão relativa dos genes $F U M$ na porcentagem de isolamento de $F$. verticillioides e na quantidade de fumonisinas $\mathrm{FB}_{1} \underline{\mathrm{e}}_{\mathbf{F B}} \underline{2}_{2}$ detectadas nos grãos de milho.

4.10.3 Fase 3: probabilidade de amplificar todos os genes $F U M$ variar em funcão da fase de desenvolvimento do milho e da porcentagem de isolamento de $F$. verticillioides..........42 5 RESULTADOS

5.1 Micobiota

5.2 Análise filogenética das cepas de Fusarium verticillioides isoladas............................48

5.3 Avaliação da metodologia analítica para as fumonisinas $\mathbf{B}_{\mathbf{1}}$ e $\mathbf{B}_{\mathbf{2}}$.............................49

5.4 Determinação de fumonisinas nos grãos de milho......................................................49 
5.5 Avaliação do Potencial Toxigênico das cepas de $F$. verticillioides isoladas

5.6 Análise da expressão dos genes $F U M$ em grãos de milho Bt por qPCR

5.6.1 Ensaio SPUD para deteccão de inibidores nas amostras de ácido nucléico

5.6.2 Análise por qPCR

5.7 Análises estatísticas

5.7.1 Fase 1

5.7.1.1 Análise do isolamento de F. verticillioides.

5.7.1.2 Análise da contaminação dos grãos de milho por $F B_{1}$

5.7.1.3 Análise da contaminação dos grãos de milho por $\mathrm{FB}_{2}$

5.7.2 Fase 2

5.7.2.1 Análise do isolamento de $F$. verticillioides

5.7.2.2 Análise da contaminação dos grãos de milho por $F B_{1}$

5.7.2.3 Análise da contaminação dos grãos de milho por $\mathrm{FB}_{2}$

5.7.3 Fase 3 .

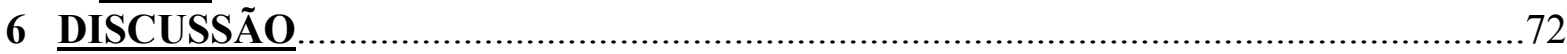

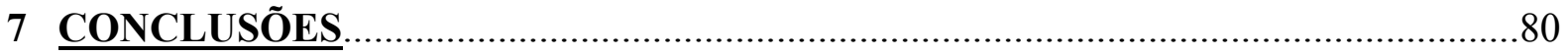

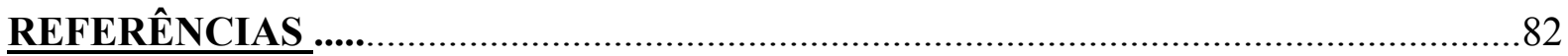

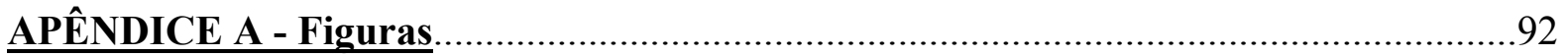

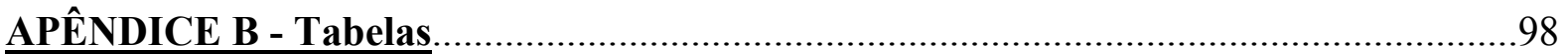




\section{INTRODUCÃ̃O}

\subsection{Milho (Zea mays L)}

A planta de milho é uma monocotiledônea pertencente à família das gramíneas, atualmente denominada Poaceae, gênero Zea; espécie Zea mays L.

A mais antiga espiga de milho, datada de 7.000 a.C, foi encontrada no Vale do Tehucan, região onde hoje se localiza o México. Chamado de "alimento dos Deuses" pelos maias, o teosinte deu origem ao milho por meio de seleção artificial. Já na época do descobrimento das Américas, o milho era o alimento base de todas as civilizações. Ao longo do tempo, o homem promoveu uma crescente domesticação do milho por meio da seleção visual no campo, e hoje, das mais de 300 raças de milho conhecidas em todo mundo, praticamente todas tiveram sua origem nos trabalhos pioneiros do homem pré-colombiano (CONSELHO DE INFORMAÇÕES SOBRE BIOTECNOLOGIA, 2006).

Figura 1. Teosinte à esquerda até o milho moderno à direita.

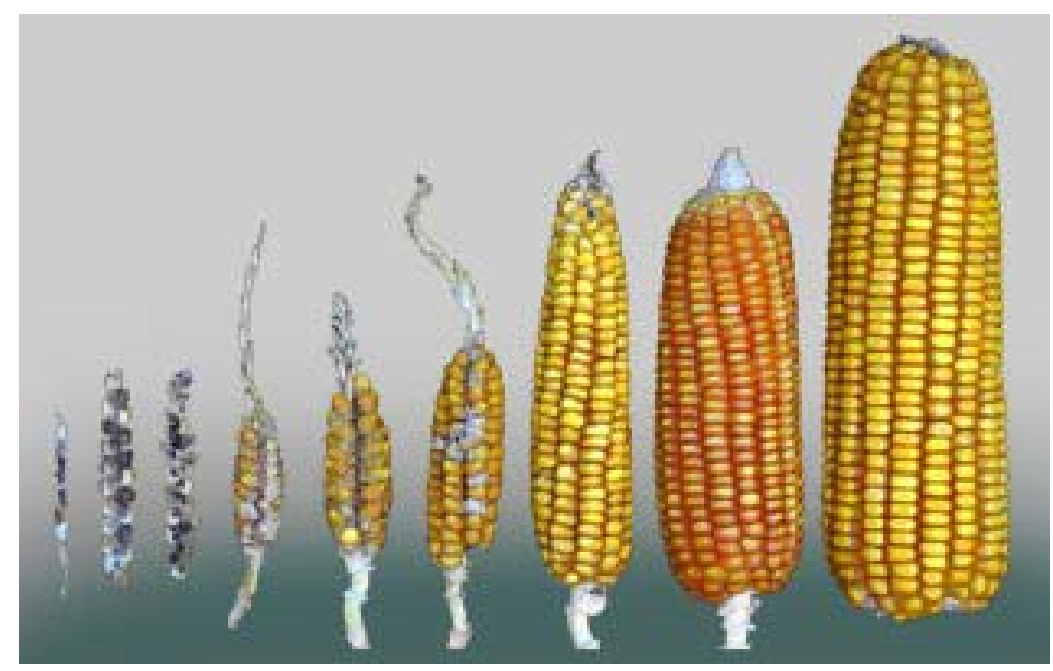

Fonte: CIB, 2006.

Quatro principais estruturas físicas formam um grão, sendo elas: o endosperma que representa aproximadamente $83 \%$ do peso seco do grão, consistindo principalmente de amido (88\%), organizado na forma de grânulos, onde também estão presentes as proteínas de reserva (8\%) e os carotenóides, substâncias lipídicas que conferem a cor aos grãos; o gérmen que representa $11 \%$ do grão de milho e concentra quase a totalidade dos lipídeos (óleo e vitamina 
E) $(83 \%)$ e dos minerais $(78 \%)$ do grão, além de conter proteínas $(26 \%)$ e açúcares $(70 \%)$; o pericarpo (casca) que é a parede celular do gametófito maduro e compreende as camadas celulares externas que envolvem o endosperma e o embrião, representa $5 \%$ do grão, sendo a estrutura que protege as demais estruturas da elevada umidade do ambiente, insetos e microrganismos; e a ponta ( $2 \%$ do grão), é responsável pela conexão do grão ao sabugo, única área do grão não coberta pelo pericarpo, sua composição é essencialmente de material lignocelulósico (PAES, 2006).

Figura 2. Estrutura anatômica e composição química do grão de milho

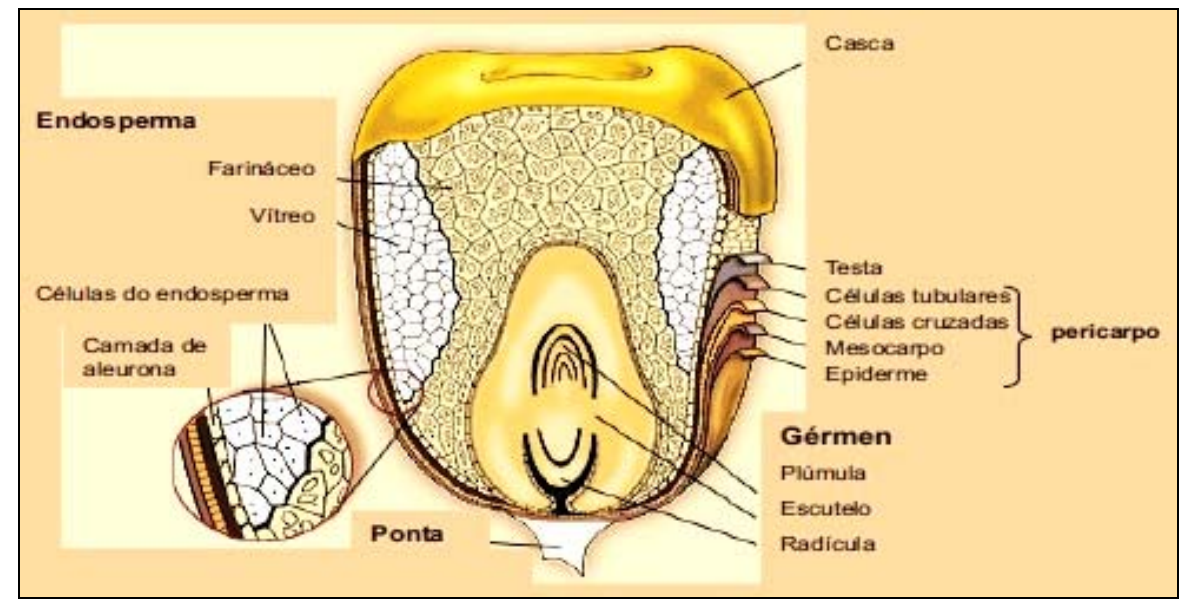

Fonte: Paes, 2006.

Com um ciclo vegetativo bem variado, evidencia desde cultivares precoces, cuja polinização pode ocorrer 30 dias após a emergência, até aqueles cujo ciclo vital pode alcançar 300 dias. Contudo, nas condições brasileiras, a cultura do milho apresenta ciclo variável entre 110 e 180 dias, em função da caracterização dos cultivares (superprecoce, precoce e normal), período este compreendido entre a semeadura e a colheita (ALMEIDA, 2001).

De forma geral, o ciclo da cultura compreende as seguintes etapas de desenvolvimento: a) germinação e emergência: período entre a semeadura até o aparecimento da plântula, cuja duração, em função da temperatura e umidade do solo, pode variar entre 5 a 12 dias; b) crescimento vegetativo: período entre a emissão da segunda folha e o início do florescimento, possui duração variável, fato que permite a caracterização dos cultivares quanto à extensão do ciclo; c) florescimento: período entre a polinização e o início da frutificação, raramente ultrapassa 10 dias (R1); d) frutificação: período entre a frutificação e o enchimento completo dos grãos, cuja duração é estimada entre 40 e 60 dias (R2 a R5); e) maturidade: período entre o final da frutificação (R6) e o aparecimento da camada negra, 
fase relativamente curta e indicativa do final do ciclo de vida da planta (RITCHIE; HANWAY; BENSON, 2003).

Para maior facilidade de manejo e estudo, bem como para a possibilidade de estabelecer correlações entre elementos fisiológicos, climatológicos, fitogenéticos, fitopatológicos e fitotécnicos, o ciclo de cultura do milho foi dividido em estádios distintos de desenvolvimento (FANCELLI, 1986).

Figura 3. Estádios de desenvolvimento da cultura de milho.

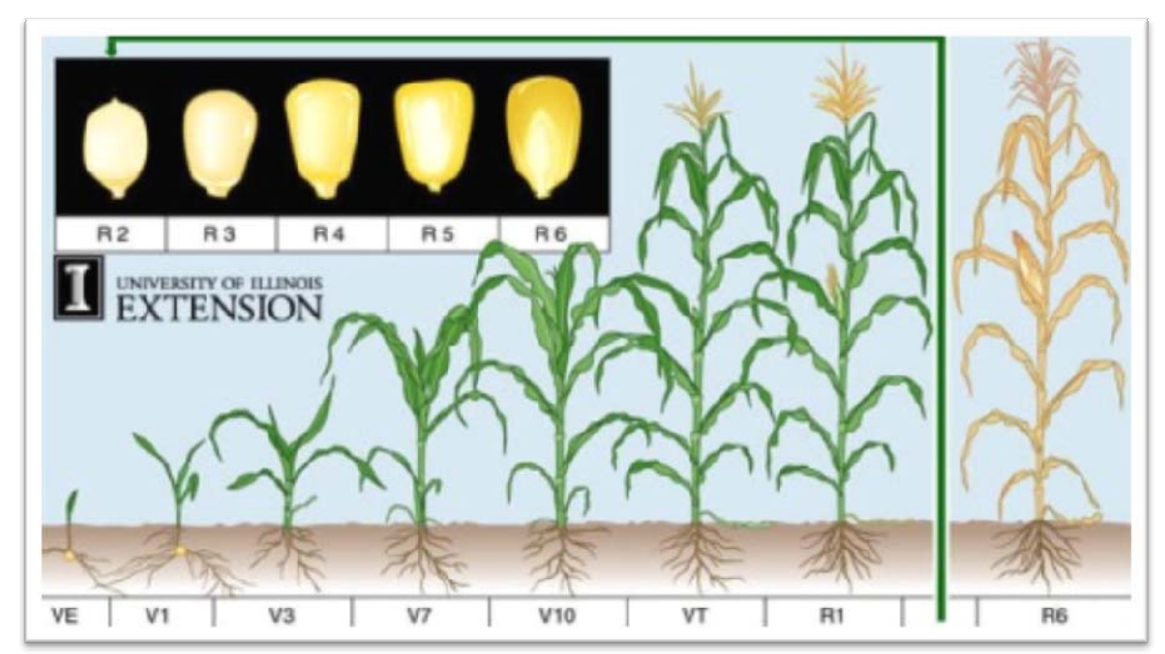

A produção do milho no Brasil cresce a cada ano, sendo que na safra 2011/2012 a colheita foi de 65 mil toneladas, a safra 2012/2013 de 76 mil toneladas (4,2\% maior) e na safra 2013/2014, a produção brasileira foi de 79 milhões de toneladas em uma área cultivada de 16 milhões de hectares (COMPANHIA NACIONAL DE ABASTECIMENTO, 2013).

Atualmente, o Brasil é considerado o terceiro maior produtor e consumidor desse grão, estando atrás dos Estados Unidos e China e terceiro maior exportador mundial de milho, superado pelos EUA e Argentina (CONAB, 2012). Em função da necessidade de aumento da produtividade, o milho tem sido submetido a um intenso melhoramento genético, resultando na existência de diversos híbridos comerciais.

\subsection{O Milho transgênico (Bt) e as toxinas Cry}

Sendo o milho cultivado em quase todas as regiões do país, com grande diversidade de situações e níveis tecnológicos, a difusão e adoção de variedade geneticamente modificadas 
resistentes à insetos, torna-se uma saída simples e compatível com as situações produtivas encontradas no Brasil. Assim, a produção e adoção de tecnologias redutoras de custos e poupadora de insumos químicos torna-se acessível a qualquer agricultor (LERAYER et al., 2011).

Recentemente, com a viabilização das técnicas de transformação de plantas, foi possível a obtenção de genótipos de milho resistentes às principais pragas como Spodoptera frugiperda (lagarta do cartucho) e Helicoverpa zea (lagarta da espiga) através da utilização de plantas que expressam o genes clonados da bactéria Bacillus thuringiensis.

Figura 4. Duas das principais pragas do milho.

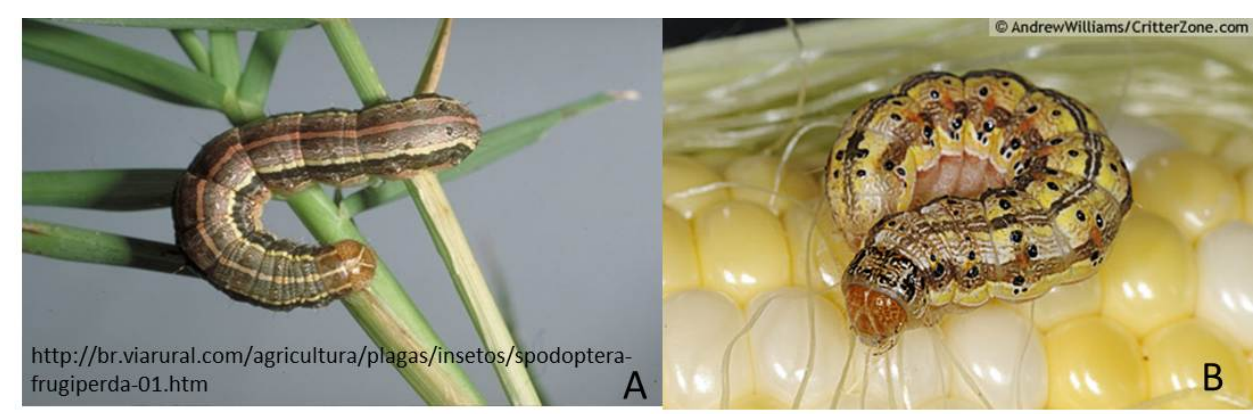

A- Spodoptera frugiperda - lagarta do cartucho. B- Helicoverpa zea - lagarta da espiga.

Bacillus thuringiensis $(\mathrm{Bt})$ é uma bactéria gram-positiva e entomopatogênica, aeróbica ou anaeróbica facultativa, encontrada naturalmente no solo. Como outras bactérias, esta espécie pode permanecer em latência na forma de endósporos, sob condições adversas. Durante a produção do esporo, essas bactérias sintetizam proteínas que se acumulam nas extremidades dos esporos sob forma de cristais em um dos polos da célula (LERECLUS, 1988). Estes cristais podem ser compostos por uma ou várias proteínas Cry, também denominadass de $\delta$-endotoxinas ou Insecticidal Crystal Proteins (ICPs). Tais proteínas são tóxicas, porém apresentam a vantagem de serem específicas, por isso inócuas para a maioria dos organismos, incluindo muitos insetos benéficos (HERRERO et al., 2001). O gene codificador para a $\delta$-endotoxina, Cryl $\mathrm{Ab}$, por exemplo, clonado de Bt tem sido amplamente utilizado por várias empresas nos EUA (BOULDER, 1993; IGNOFFO; GREGORY, 1972; WAQUIL et al., 2004).

As toxinas Cry apresentam formas variáveis e constituem proteínas com massa variável entre 27 a 140 kDa (AUGUSTYNIAK; DABERT; WYPIJEWSKI, 1997). Os genes codificadores de $\delta$-endotoxinas estão localizados, em sua maioria, em grandes plasmídeos. 
Alguns isolados de Bt contêm múltiplos genes de $\delta$-endotoxina (KRONSTAD; SCHNEPF; WHITELEY, 1983).

O mecanismo de ação das $\delta$-endotoxinas, constituintes dos cristais, se dá da seguinte maneira: as proteínas Cry (protoxinas) são solubilizadas e proteoliticamente convertidas em polipeptídeos menores no trato digestivo das larvas suscetíveis. Estes polipeptídeos associamse a receptores específicos de ligação nas microvilosidades apicais das células do intestino dos insetos, causando lise osmótica através da formação de poros na membrana (FIUZA et al.,1996).

Figura 5. Mecanismo de ação das proteínas Cry em insetos susceptíveis.

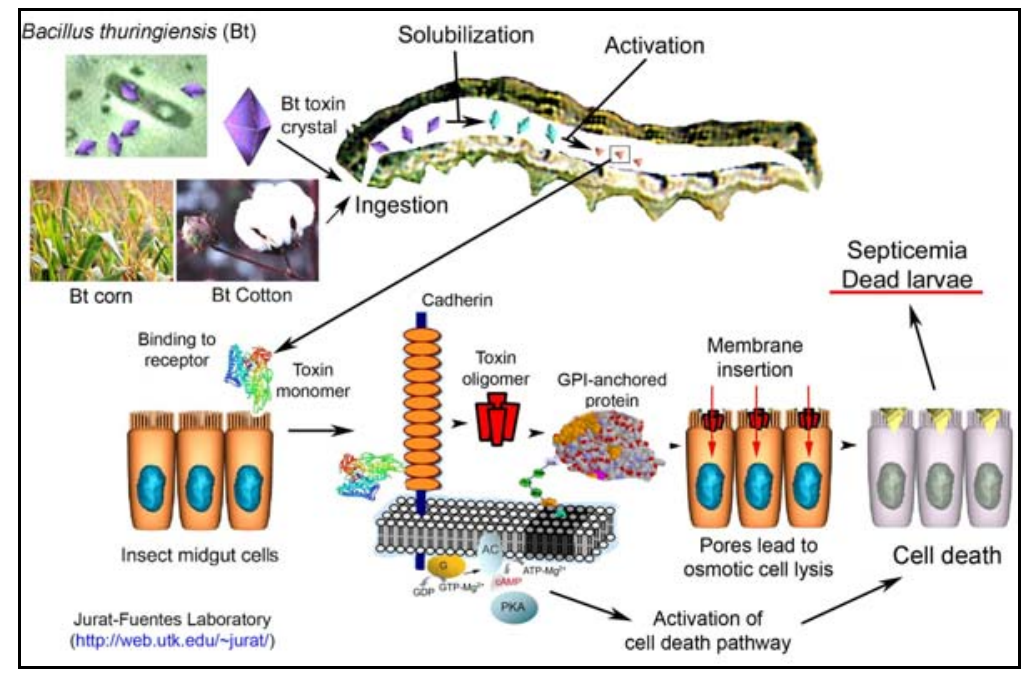

Diversas vantagens também são atribuídas às variedades de milho $\mathrm{Bt}$, tais como a necessidade de uso de menor quantidade de inseticidas, oferecendo menor risco de contaminação do lençol freático e dos rios, além de um menor consumo de água, gerando maior produtividade e maior rentabilidade (CASTRO, 2008), e o fato de não haver diferença na abundância e variabilidade das espécies de insetos nos campos plantados com milho Bt, quando comparados com os convencionais não tratados com inseticida, com exceção da espécie-alvo e de seus parasitas específicos (LERAYER et al., 2011).

Segundo Carneiro et al. (2009), existem duas metodologias para a inserção de genes codificadores para as toxinas Cry no genoma do milho: a transformação genética indireta e a direta. A metodologia direta envolve o bombardeamento de células vivas com o DNA de interesse através da utilização de micropartículas de tungstênio ou ouro cobertas com o gene (SANFORD et al., 1987), enquanto que a metodologia indireta se dá através da transformação 
via bactéria Agrobacterium tumefaciens. Essa bactéria possui o plasmídeo Ti, que pode se replicar independentemente do genoma da bactéria (CARNEIRO et al., 2009; GELVIN, 2003). A Figura 6 esquematiza essas duas metodologias citadas acima em algodão, a exemplo do que ocorre para os genes Bt em milho.

Figura 6. Mecanismo de inserção de genes bacterianos em tecidos de plantas.

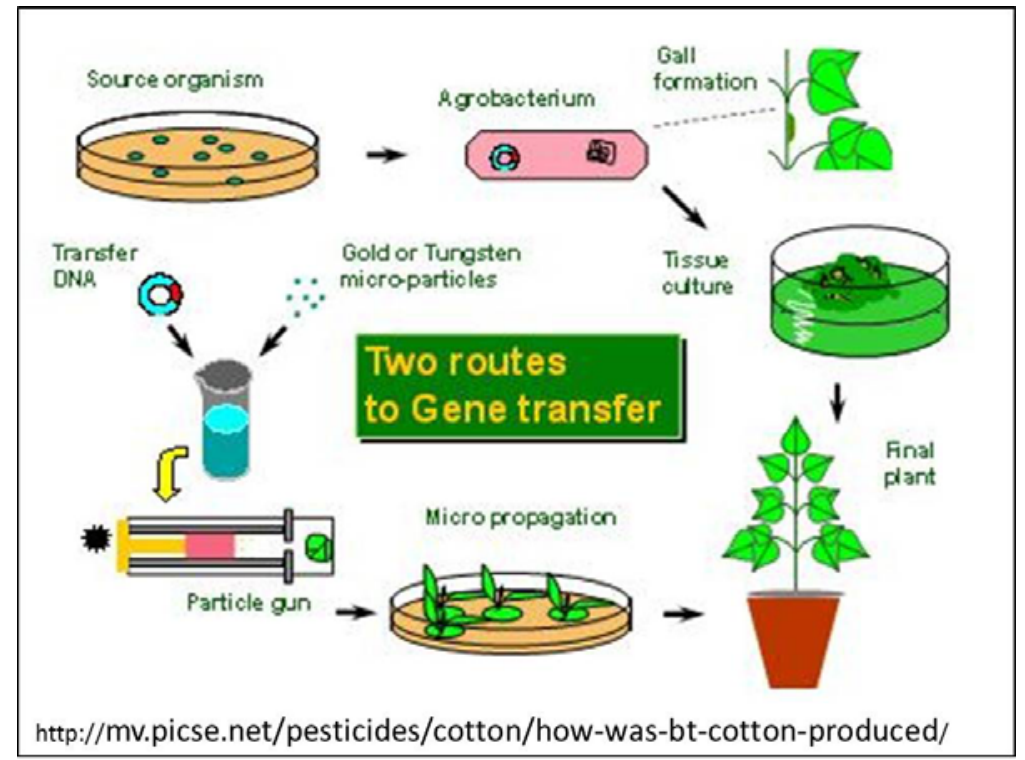

Em 1995, as primeiras plantas transgênicas foram aprovadas para venda nos EUA, tais como milho expressando Cry1A(b) (Maximizer ${ }^{\mathrm{TM}}$ da Novartis Corporation, Basileia-Cidade, Basileia, Suíça), algodão expressando Cry1A(c) (Bollgard $^{\mathrm{TM}}$ da Monsanto, Creve Coeur, Missouri, Estados Unidos) e batata expressando Cry IIIA (Newleaf ${ }^{\mathrm{TM}}$ da Monsanto, Creve Coeur, Missouri, Estados Unidos) e em 1996, os milhos Bt já ocupavam mais de 1,2 milhões de hectares nos EUA (JOUANIN et al., 1998).

Menos de 20 anos depois o Brasil já possui o título de terceiro maior produtor de transgênicos, responsável por $12 \%$ da área total com plantação de espécies transgênicas no mundo, superado pela Argentina e EUA (JAMES, 2007).

Para a produção do milho $\mathrm{Bt}$ que produz a proteína Cry1F, o gene $\operatorname{cry} l F$ foi originalmente isolado de Bacillus thuringiensis var. aizawai (ENVIRONMENTAL PROTECTION AGENCY, 2005). Esta proteína controla efetivamente algumas larvas de insetos lepidópteros, como por exemplo a broca do milho europeia (Ostrinia nubilalis). CrylF é uma pró-toxina de $130 \mathrm{kDa}$ que é clivada a uma toxina ativa de $65 \mathrm{kDa}$ (GAO et al., 2006). Segundo a Environmental Protection Agency (2005), há um risco mínimo de 
toxicidade ou de efeitos alérgicos em humanos ou animais expostos à proteína Cry $1 \mathrm{~F}$, e ainda há uma certeza de que não há efeitos maléficos à saúde humana ou animal devido à exposição aos resíduos desta proteína. Além disso, esta mesma agência afirma que a proteína Cry1F não causa efeitos prejudiciais mensuráveis para população microbiológica nos solos, mesmo em níveis muito maiores ao esperado em culturas de milho Bt Cry1F. No Brasil, em 2008, ocorreu a regulamentação para cultivo do milho Bt Cry1F (CENTER FOR ENVIRONMENTAL RISK ASSESSMENT, 2013).

\subsection{Micobiota do milho e Fusarium verticillioides}

Os grãos em geral, são constantemente expostos, no campo, a uma ampla variedade de microrganismos, provenientes da poeira, água, plantas doentes, insetos, fertilizantes e material orgânico de animais. Seus esporos ou fragmentos de micélio darão início à contaminação e desenvolvimento do fungo na planta, particularmente em sementes imaturas. A quantidade e os tipos destes microrganismos dependem, principalmente, das condições climáticas durante o plantio e do estágio de desenvolvimento e maturação do grão (LACEY, 1975; SILLIKER; ELLIOTT, 1980).

Os grãos de milho são frequentemente contaminados com espécies dos gêneros Aspergillus, Penicillium e Fusarium. Os fungos são causadores de diminuição da germinação e de lesões nas plântulas, desencadeando menor desenvolvimento destas (ROSSETTO; SILVA; ARAÚJO, 2005). Além do emboloramento visível, causam descoloração, odor desagradável, perda de matéria seca, aquecimento, perda da qualidade e produção de micotoxinas (CHRISTENSEN; KAUFMAN, 1965).

As principais espécies do gênero Fusarium associadas aos grãos de milho são $F$. verticillioides, F. proliferatum, F. subglutinans (membros do complexo Gibberella fujikuroi) e F. graminearum. A espécie $F$. verticillioides, considerada como principal patógeno do milho, predomina em regiões tropicais e áreas temperadas úmidas, mas é pouco frequente em zonas temperadas frias. Por sua vez, F. graminearum predomina em regiões de clima tropical a temperado (LESLIE; SUMMERELL, 2006). Espécies do gênero Fusarium, necessitam para seu crescimento de teor de umidade de $20 \% / 21 \%$ e Aa entre 0,80 e 0,90 (CAHAGNIER; MELCION; RICHARD-MOLARD, 1995; LACEY; MEGAN, 1991).

F. verticillioides (Nirenberg), sinônimo de F. moniliforme (Sheldon) é uma espécie fúngica ubíqua, predominante em regiões tropicais e temperadas. Possui uma fase anamórfica (assexuada), sendo denominado de $F$. verticillioides, e uma teleomórfica (sexuada), conhecida 
como Gibberella moniliformis (sinônimo de Gibberella fujikuroi) (LESLIE, 1996; COVARELLI et al., 2012). Taxonomicamente, faz parte de um complexo de espécies denominado Gibberella fujikuroi, anteriormente agrupado na seção Liseola. Este complexo é composto por 9 espécies biológicas ou populações mating, designadas pelas letras de "A" a "I". F. verticillioides, espécie mais frequentemente isolada do milho e capaz de produzir elevados níveis de fumonisinas, pertencente à população mating "A”. As espécies biológicas “D” (F. proliferatum) e "E” (F. subglutinans) também são isoladas do milho, sendo que a primeira produz quantidades significativas de fumonisinas e a segunda, níveis baixos ou não são capazes de sintetizá-las (LESLIE, 1996; LESLIE; SUMMERELL, 2006).

Figura 7. Micromorfologia e Macromorfologia de F. verticillioides.

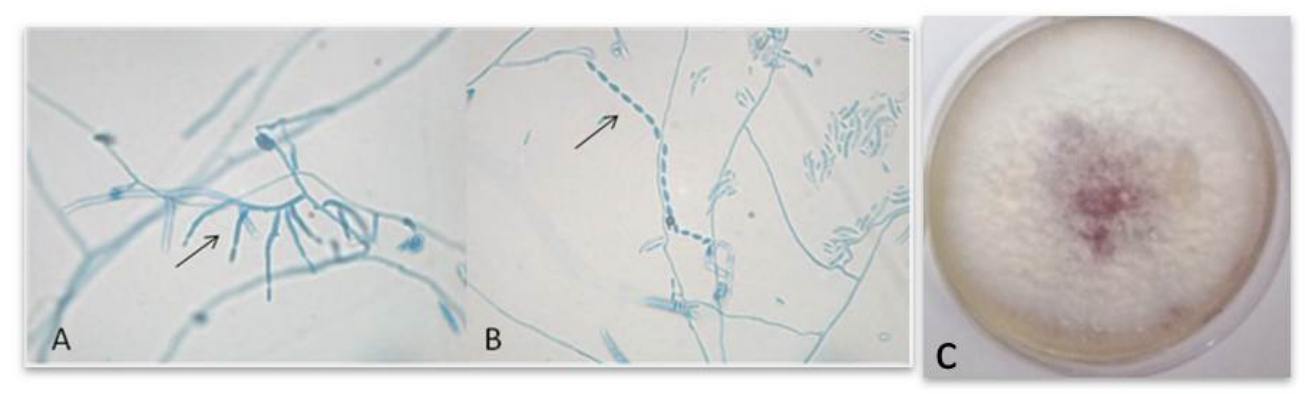

A- Monofiálides (seta), B- longa cadeia de microconídeos (seta). C- Macromorfologia.

F. verticillioides pode infectar os grãos por três vias, invasão sistêmica, mediante contaminação das sementes, sendo considerado um fungo endofítico; por fissuras na planta já desenvolvida; ou através do "cabelo do milho" (MUNKVOLD; MCGEE; CARLTON, 1997). Dentre essas rotas de contaminação, a infecção nos grãos ocorre de forma mais agressiva quando as cepas de $F$. verticillioides são inoculadas nos "cabelos do milho", proporcionando rompimento da casca e maior severidade no apodrecimento da espiga (WARFIELD; DAVIS, 1996).

F. verticillioides, como outros fungos endofíticos, pode residir internamente nos tecidos de plantas saudáveis sem causar nenhum efeito negativo, mas podem se tornar patogênicos, por exemplo, durante a senescência do hospedeiro (ALY et al., 2010; ROCHA et al., 2014). A interação entre a planta hospedeira e a espécie endofítica são pobremente entendidas, entretanto, eles podem ativamente competir contra outros microrganismos por nicho ou sítios de infecção (ALY et al., 2010). 
Fusarium verticillioides é o mais prevalente fungo associado com alimentos à base de milho e subproduto s pertencentes às dietas humana e animal. Tem grande importância por ser produtor de micotoxinas, principalmente as fumonisinas.

A faixa de temperatura e a atividade de água mínima para o crescimento dessa espécie são de 2 a $37^{\circ} \mathrm{C}$ e 0,87 , respectivamente. Para a produção de fumonisinas a Aa mínima é 0,90 (CAHAGNIER; MELCION; RICHARD-MOLARD, 1995).

\subsection{As fumonisinas}

Até o presente momento, 28 fumonisinas foram isoladas e caracterizadas, sendo a fumonisina $\mathrm{B}_{1}\left(\mathrm{FB}_{1}\right)$ a mais importante do grupo. Esta micotoxina pode ocasionar leucoencefalomalácia em equinos (LEME), edema pulmonar em suínos, câncer hepático em ratos, redução do desenvolvimento, imunossupressão, problemas cardíacos, degeneração e necrose hepática em aves, além de estar associada ao câncer esofágico em humanos (MARASAS, 1996). São consideradas pela "International Agency for Research on Cancer" (IARC) como possivelmente carcinogênicas para seres humanos

As principais fumonisinas detectadas em culturas do fungo e em milho são as fumonisinas $\mathrm{B}_{1}\left(\mathrm{FB}_{1}\right), \mathrm{B}_{2}\left(\mathrm{FB}_{2}\right)$ e $\mathrm{B}_{3}\left(\mathrm{FB}_{3}\right)$ (ORSI et al., 2000). A FB 1 é a mais abundante, representando cerca de $70 \%$ da concentração total das fumonisinas em alimentos ou em produtos alimentícios naturalmente contaminados, seguida pela $\mathrm{FB}_{2}$ e $\mathrm{FB}_{3}$ (MAGNOLI et al., 1999).

Seu mecanismo de ação está relacionado com a inibição do metabolismo dos esfingolipídios, componentes das membranas celulares que possuem papel na regulação celular e no controle de proteínas de membrana, mediando o crescimento, a diferenciação e a morte celular (LINO; SILVA; PENA, 2004; TURNER; NIKIEMA; WILD, 1999). Nas células dos mamíferos, as bases esfingóides mais comuns são as esfingosina e a esfinganina. As fumonisinas, são inibidores competitivos da esfinganina $\mathrm{N}$-aciltransferase e da esfingosina $\mathrm{N}$-aciltransferase (ceramida sintetase), uma vez que, estruturalmente, são análogas de bases esfingóides. As enzimas anteriormente referidas são elementos chave para a via metabólica da biossíntese dos esfingolipídeos (LINO; SILVA; PENA, 2004). Assim, as fumonisinas alteram a concentração e a proporção entre a esfinganina e a esfingosina, diminuindo a biossíntese de esfingosina e acumulando esfinganina. Também bloqueiam a biossíntese de esfingolipídeos complexos em células eucarióticas. Consequentemente, ocorrem os efeitos deletérios nas 
células eucarióticas como a indução de apoptose e efeitos carcinogênicos (LINO; SILVA; PENA, 2004).

Figura 8. Quadro comparativo de diferentes tipos de fumonisinas.

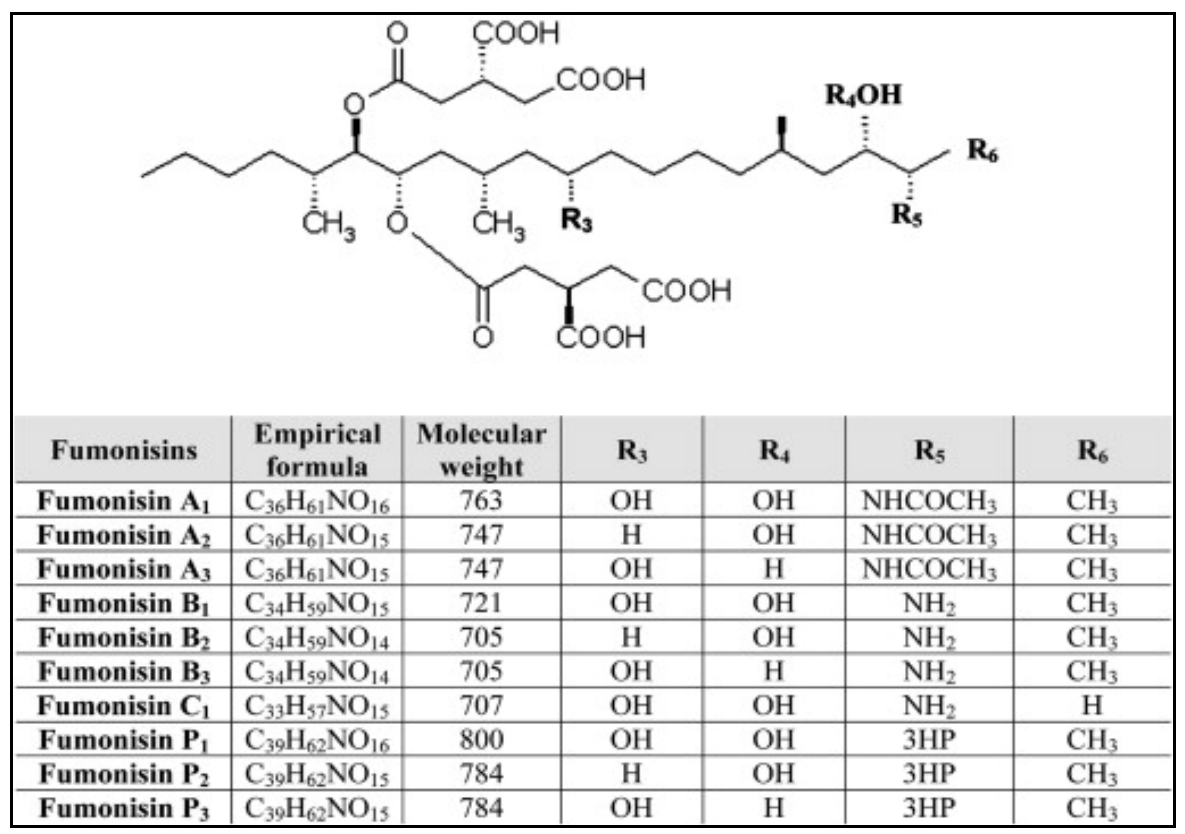

Fonte: Waśkiewicz; Beszterda; Golinski, 2012.

Não existe, até o momento, uma legislação global para os limites de fumonisinas em alimentos. No Brasil, em 2011, estipulou-se a recomendação para limites máximos tolerados de $\mathrm{FB}_{1}+\mathrm{FB}_{2}$ para milho de pipoca $(2 \mu \mathrm{g} / \mathrm{g})$ e alimentos a base de milho para alimentação infantil $(0,2 \mu \mathrm{g} / \mathrm{g})$. A partir de 2012, outros alimentos foram adicionados à resolução, como farinha de milho, creme de milho, fubá, flocos, canjica e canjiquinha $(2,5 \mu \mathrm{g} / \mathrm{g})$ e amido de milho e outros produtos a base de milho $(2 \mu \mathrm{g} / \mathrm{g})$ (BRASIL, 2011).

\subsection{Genes relacionados com a biossíntese de fumonisinas}

Os genes relacionados à produção de fumonisinas estão localizados no cromossomo 1 de F. verticillioides formando um grupo (cluster) de 17 genes, em uma região com aproximadamente $42,5 \mathrm{~kb}$ e todos genes co-regulados (BROWN et al., 2007; KHALDI; WOLFE, 2011; PROCTOR et al., 1999).

O gene FUM1 codifica uma policetídeo sintase que catalisa o primeiro passo da biossíntese das fumonisinas. A interrupção desse gene resulta na redução de mais de $99 \%$ da produção de fumonisinas na cultura. FUM9 produz uma dioxigenase que catalisa a oxigenação do carbono 5; FUM6 possui elevada similaridade com membros da enzima 
citocromo P450 monoxigenase, ligada a uma P450 redutase NADPH dependente. FUM8 codifica uma proteína semelhante ao grupo das aminotransferases, que catalisa a condensação dos aminoácidos em acetil coenzima A. Os genes FUM7, FUM10, FUM11 e FUM14 estão envolvidos na esterificação do ácido tricarboxílico ou na biossíntese desse grupos presentes na estrutura química das fumonisinas. FUM13 codifica uma proteína similar às desidrogenases/ redutases com cadeia curta, apresentando atividade carbonil redutase. Essa enzima catalisa a redução da carbonila presente no carbono 3 a uma hidroxila. Todos estes nove genes são estritamente ligados à biossíntese das fumonisinas. A interrupção dos mesmos, proporciona interrupção da produção dessas toxinas (DESJARDINS, 2006).

Os genes FUM12 (também denominado FUM2) e FUM15 codificam monoxigenases com similaridade a do citocromo P450; FUM17 e FUM18 codificam fatores que garantem longevidade e podem estar associados à proteção da fumonisina. Os outros genes FUM11 e FUM19 codificam transportadores, sendo que a enzima produzida por FUM19 pode atuar como uma bomba de efluxo, reduzindo a concentração celular de toxinas (DESJARDINS, 2006; PROCTOR et al., 2003). O gene FUM21 está envolvido regulação da transcrição, uma vez que a proteína possui um domínio Zn(II)2Cys6 DNA-binding (BROWN et al., 2007).

Figura 9. Genes envolvidos na biossíntese de fumonisinas.

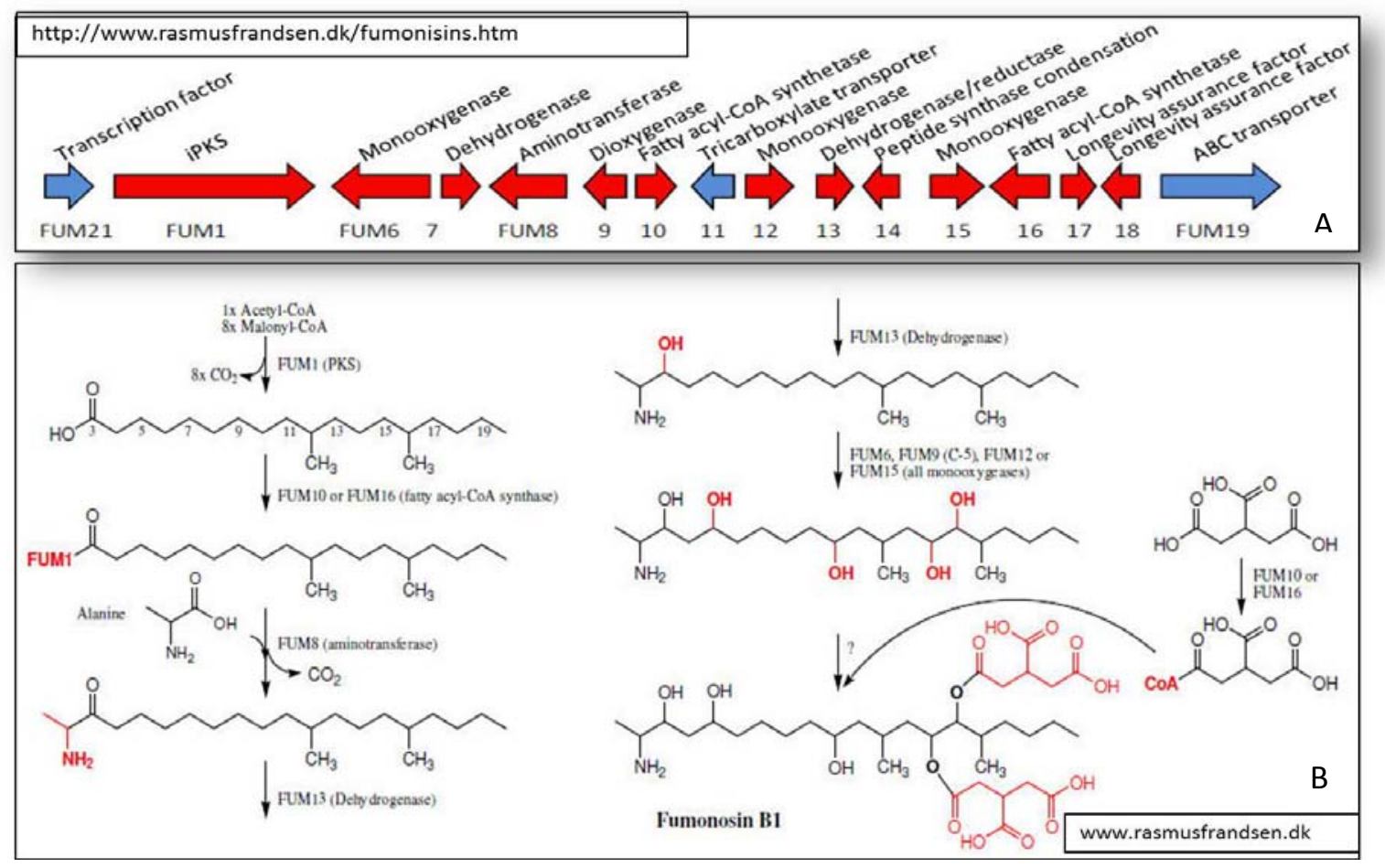

A- Genes envolvidos na produção da fumonisina e suas respectivas enzimas. B- Esquematização da via biossintética da fumonisina $\mathrm{B}_{1}$. 
Dentre as técnicas atualmente utilizadas na detecção de genes responsáveis pela produção de micotoxinas, inclui-se o sequenciamento, podendo identificar mutação em apenas uma única base nitrogenada. Entretanto, essas mutações podem ser silenciosas, podendo não afetar a estrutura do aminoácido ou a atividade da proteína produzida (ZAHA, 1996).

A complexidade na correlação entre as sequências de DNA e os níveis de produção de micotoxinas contribuiu para o desenvolvimento de técnicas para análise da expressão dos genes envolvidos na biossíntese de micotoxinas. Dentre estas, destaca-se a PCR quantitativa em tempo real $(q P C R)$, amplamente utilizada, garantindo rapidez, elevada especificidade, além de propiciar a quantificação da expressão dos genes analisados (LOPÉZ-ERRASQUIN et al., 2007; MAYER; FÄRBER; GEISEN, 2003).

A correlação da expressão de genes responsáveis pela produção de micotoxinas com os fatores abióticos, indica que o nível de transcritos pode ser utilizado para averiguar a indução ou inibição da produção de toxinas frente a estes fatores (JURADO et al., 2008; SCHMIDTHEYDT et al., 2009).

Estudos conduzidos por Duvick (2001), Munkvold, Hellmich e Rice (1999) e Papst et al. (2005), demonstraram diminuição na produção de fumonisinas por $F$. verticillioides em milho Bt. Hammond et al. (2004) verificaram diminuição nos níveis de fumonisinas em híbridos $\mathrm{Bt}$ contendo a proteína Cry $1 \mathrm{Ab}$ durante o desenvolvimento da cultura em condições naturais e com infestação forçada pelos insetos Ostrinia nubilalis e Diatraea grandiosella (broca europeia do milho e broca do milho do sudoeste, respectivamente). Estes autores atribuem a diminuição na produção de fumonisinas pela queda da infestação dos insetos nos grãos e, consequentemente, manutenção da integridade dos mesmos, dificultando a entrada de fungos toxigênicos, como Fusarium (DUVICK, 2001).

Entretanto, nenhum estudo envolvendo a expressão de todos os genes responsáveis pela via biossintética das fumonisinas (cluster FUM) em grãos de milho $\mathrm{Bt}$ nas diferentes etapas de crescimento e amadurecimento do grão foi encontrado na literatura. Além disso, os genes responsáveis pela biossíntese das micotoxinas não são expressos de forma constitutiva, permitindo a análise do perfil da expressão frente às diferentes etapas e condições climatológicas durante o amadurecimento do grão. O estudo da expressão desses genes pode ser utilizado como indicativo da biossíntese de micotoxinas no alimento como também para diagnóstico de substâncias que possam suprimir alguma etapa da via biosintética, uma vez que a expressão dos genes pode ser medida antes mesmo da possível detecção das fumonisinas por métodos analíticos. 
Estes fatos, associado ao grande significado econômico da cultura do milho, as perdas econômicas decorrentes da contaminação por fungos e por micotoxinas, principalmente fumonisinas, e a tendência de substituição do milho convencional pelo transgênico (Bt) motivaram o presente trabalho. 


\section{OBJETIVOS}

Os grãos são expostos, tanto no campo como no armazenamento à ação dos fatores físicos, químicos e biológicos que interagem entre si favorecendo o processo de deterioração, podendo ocasionar danos à saúde e perdas na produtividade.

Em decorrência destes fatores, estudos sobre a distribuição de fungos, micotoxinas como também sobre o comportamento genético destes microrganismos contribuem para a melhoria de estratégias para controle da contaminação. Essas informações facilitam a produção de fungicidas mais eficientes ou sementes geneticamente modificadas mais resistentes aos patógenos, favorecendo, assim, a adoção de medidas de controle e de prevenção da contaminação fúngica e produção de micotoxinas.

Fusarium verticillioides é um fungo endofítico associado aos grãos de milho, que ocasiona perda de produtividade, qualidade e consequentemente queda na exportação. Esse fungo também é capazes de produzir elevados níveis de fumonisinas, proporcionando riscos à saúde humana e animal. Alguns estudos têm relatado a diminuição na produção de fumonisinas por $F$. verticillioides em milho transgênico $(\mathrm{Bt})$, capaz de expressar entomotoxinas produzidas por Bacillus thuringiensis ( $\beta$-exotoxina e $\delta$-endotoxina - toxinas cry). A queda na produção de fumonisinas pode ser explicada pela redução da infestação por insetos nos grãos, impedindo o desenvolvimento do fungo. Entretanto, nenhum estudo envolvendo a expressão de todos os genes responsáveis pela via biossintética das fumonisinas (cluster FUM) em grãos de milho Bt nas diferentes etapas de crescimento e amadurecimento do grão foi encontrado na literatura.

Este fato, associado ao grande significado econômico da cultura do milho, as perdas econômicas decorrentes da contaminação por fungos e por micotoxinas, principalmente fumonisinas, e a tendência de substituição do milho convencional pelo transgênico (Bt) motivaram a presente pesquisa que teve como objetivo geral avaliar a expressão dos genes FUM como indicativo da contaminação por $F$. verticillioides e da produção de fumonisinas nos grãos de milho durante todo o processo de amadurecimento dos grãos.

Assim, os objetivos específicos foram:

1-Identificação da micobiota em sete períodos de amadurecimento dos grãos de milho (híbrido 2B710 HX);

2-Identificação das espécies de Fusarium isoladas dos grãos 
3-Obtenção de um dendrograma filogenético através dos dados obtidos por sequenciamento parcial do gene $T E F-1 \alpha$ das cepas de $F$. verticillioides, isoladas do milho nas diferentes etapas.

4-Verificação da contaminação dos grãos por fumonisinas $\left(\mathrm{FB}_{1}\right.$ e $\left.\mathrm{FB}_{2}\right)$, em diferentes períodos do desenvolvimento dos grãos no campo;

5- Verificação do perfil de expressão de 16 genes $F U M$ de $F$. verticillioides no milho;

6- Correlação da micobiota dos grãos com os níveis de Aa das amostras;

7- Análise do potencial toxigênico de 217 cepas de $F$. verticillioides isoladas dos grãos de milho dos diferentes períodos;

8- Comparação dos resultados obtidos com os fatores climatológicos da região de plantio: umidade relativa do ar $(\%)$, índice pluviométrico $(\mathrm{mm})$ e temperatura $\left({ }^{\circ} \mathrm{C}\right)$;

9- Análise estatística e correlação dos resultados obtidos em todos os períodos de amadurecimento estudados. 


\section{FLUXOGRAMA}

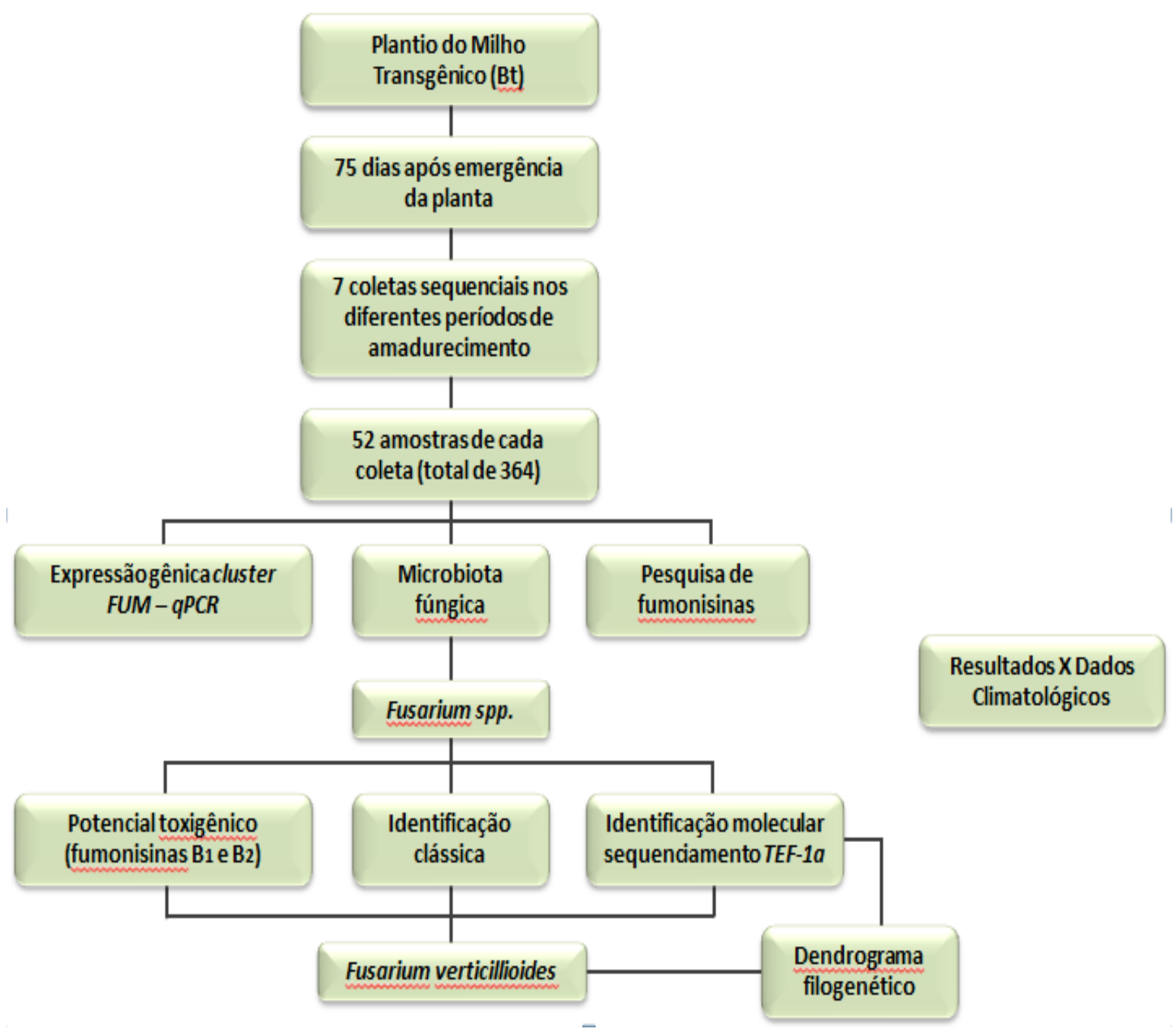




\section{MATERIAIS E MÉTODOS}

\subsection{Amostragem}

As sementes de milho Bt (2B710HX, híbrido que expressa cry1F) foram semeadas no município de Cruzália, região de Assis, estado de São Paulo, no mês de outubro de 2010. A amostragem foi realizada semanalmente a partir do $75^{\circ}$ dia após a emergência das plantas (início do florescimento, estádio R1), nas seis primeiras coletas (diferentes estádios), e uma sétima coleta no momento da colheita final do agricultor, 3 semanas após a sexta coleta. Para tal amostragem foi utilizado a metodologia de Delp, Stewell e Marois (1986) adaptada. Para cada coleta o local de plantio foi dividido em 10 parcelas uniformes de $80 \mathrm{~m}^{2}$. Foram escolhidas, 4 parcelas e de cada uma dessas parcelas foram colhidas 13 espigas de milho, totalizando 52 amostras por coleta e 364 amostras no estudo.

\subsection{Atividade de água}

Análise da atividade de água das amostras foi determinada através do aparelho AQUALAB CX-2 (Decagon Devices Inc, Pullman, Washington, Estados Unidos).

\subsection{Micobiota das amostras de milho}

\subsubsection{Meios de cultura}

Para o isolamento e contagem da micobiota, foi utilizado o meio de cultura Ágar Dicloran Rosa Bengala Cloranfenicol (DRBC - Oxoid, Basingstoke, Hampshire, Inglaterra) (PITT; HOCKING, 2009). As colônias dos diversos gêneros foram então transferidas para Ágar Batata (PDA - Oxoid) para identificação. O meio Ágar Spezieller Nährstoffarmer (SNA) foi usado para identificação das espécies pertencentes à Fusarium através da cultura em lâminas (microcultivo). A manutenção das cepas de Fusarium foi realizada em meio SNA e PDA. 


\subsubsection{Técnica da semeadura direta para o isolamento da micobiota das amostras de grãos de milho (BERJAK, 1984)}

De cada amostra, uma sub-amostra de grãos $(1 \mathrm{Kg})$ foi retirada e analisada em relação à micobiota. De cada sub-amostra de milho foram retirados, aproximadamente, $30 \mathrm{~g}$ para desinfecção em solução de hipoclorito de sódio $(2 \%)$ por 3 minutos. Tal procedimento é utilizado para eliminação dos contaminantes externos. Após a desinfecção, os grãos foram lavados, por 3 vezes, com água destilada esterilizada. Trinta e três grãos foram selecionados ao acaso e semeados diretamente em placas de Petri contendo Ágar DRBC. Foram utilizadas 3 placas contendo 11 grãos para cada uma das amostras. As placas foram incubadas a $25^{\circ} \mathrm{C}$ por 5 dias e os resultados expressos em porcentagem do total de grãos inoculados infectados por fungos.

As colônias de diferentes tipos morfológicos foram transferidas para Ágar Batata e submetidas à identificação em nível de gênero através de macro e microscopia (PITT; HOCKING, 2009). Entretanto, aqueles pertencentes ao gênero Fusarium, foram incubadas a $25^{\circ} \mathrm{C}$ por 7-15 dias sob luz branca e luz negra (12 h/dia) em cultivo em lâmina com meio SNA (microcultivo), e, subsequentemente classificados até espécie. A identificação dos gêneros se deu de acordo com os seguintes compêndios: Leslie e Summerell, 2006; Nelson, Touson e Marasas, 1983; Nelson, 1992; Pitt e Hocking, 1997. A figura 7 mostra algumas características de $F$. verticillioides.

\subsection{Identificação das espécies de Fusarium através do sequenciamento parcial do gene do Fator de Elongação Alfa (TEF-1a) (GEISER et al., 2004)}

A identificação morfológica das espécies de Fusarium foi confirmada através do sequenciamento parcial do gene do fator de elongação 1- $\alpha$, utilizando os primers forward e reverse, ef-1/ef-2. O amplicon tem aproximadamente $650 \mathrm{pb}$.

\subsubsection{Extraç̃o do DNA}

Para a obtenção da biomassa fúngica, as cepas selecionadas foram semeadas em placas de Petri contendo meio YES (ágar sacarose-extrato de levedura) (ABDOLLAHI; BUCHANAN, 1981; DEGOLA et al., 2007), e incubadas por 5 dias a $25^{\circ} \mathrm{C}$. Após esse período, os micélios das placas foram retirados, acondicionados em microtubos e mantido a $20{ }^{\circ} \mathrm{C}$. Posteriormente, o DNA genômico das cepas de Fusarium spp. foram extraídos 
conforme o manual de instruções do kit Easy-DNA (Invitrogen, Carlsbad, Califórnia, Estados Unidos).

Um fragmento do micélio obtido foi macerado em gral e pistilo previamente esterilizados, transferido para microtubo de 1,5 mL, foram adicionados $350 \mu \mathrm{L}$ da solução A e o conteúdo incubado a $65^{\circ} \mathrm{C}$ por 15 minutos. Foram adicionados $150 \mu \mathrm{L}$ da solução $\mathrm{B}$, em seguida, $500 \mu \mathrm{L}$ de clorofórmio. As amostras foram centrifugadas a $14000 \mathrm{rpm}$ por 20 minutos, posteriormente, a fase superior foi transferida para um novo microtubo de $1,5 \mathrm{~mL}$ contendo $1 \mathrm{~mL}$ de etanol absoluto $\left(-20^{\circ} \mathrm{C}\right)$ e mantidas por 1 hora em gelo. As amostras foram submetidas à centrifugação (14000 rpm/ 15 minutos) e o etanol removido, foram lavadas com etanol $80 \%\left(-20^{\circ} \mathrm{C}\right)$ duas vezes e em seguida mantidas 5 minutos à temperatura ambiente.

O resíduo de DNA das amostras foi resuspendido em $100 \mu \mathrm{L}$ de tampão de eluição (TE) e $20 \mu \mathrm{L}$ de RNAse $(2 \mathrm{mg} / \mathrm{mL})$, incubado a $37^{\circ} \mathrm{C}$ por 30 minutos e mantido a $-20{ }^{\circ} \mathrm{C}$ até a utilização. A quantificação e a verificação do grau de pureza das amostras foram realizadas em Nanodrop 2000 C (Thermo Scientific Waltham, Tewksbury, Massachusetts, USA) e a concentração dada em ng/ $\mu \mathrm{L}$.

\subsubsection{Amplificacão parcial do gene do fator de elongaç̃o 1 alfa $(T E F-1 \alpha)$}

A região entre os nucleotídeos 75 a 978 do gene TEF-1 $\alpha(\sim 650$ pb) foi amplificada pela técnica de PCR (Reação em Cadeia da Polimerase). O fragmento foi amplificado em termociclador Applied Biosystems Thermocycler GeneAmp ${ }^{R} 9700$ (Applied Byosistems, Perkin-Elmer, Gouda, The Netherlands), utilizando-se os iniciadores forward e reverse ef1/ef-2, respectivamente 5'- ATGGGTAAGGA(A/G)GACAAGAC-3' e 5' $^{\prime}$ GGA(G/A)GTACCAGT(G/C)ATCATGTT-3', conforme descrito por Geiser et al. (2004). O volume total da reação foi de $25 \mu \mathrm{L}$, utilizando-se buffer 1 x, $2,5 \mathrm{mM}$ de $\mathrm{MgCl}_{2}, \mathrm{dNTP}$ a 0,2 $\mathrm{mM}$, iniciadores a $0,3 \mathrm{mM}$, Taq DNA polimerase a $0,04 \mathrm{U} / \mu \mathrm{L}$ e $3 \mu \mathrm{L}$ do DNA concentrado. Os parâmetros da amplificação foram: $94{ }^{\circ} \mathrm{C}$ a 1 minuto para a desnaturação inicial, 25 ciclos a $94{ }^{\circ} \mathrm{C}$ (30 segundos), $55^{\circ} \mathrm{C}$ ( 45 segundos), $72{ }^{\circ} \mathrm{C}$ (30 segundos) e um ciclo adicional de 72 ${ }^{\circ} \mathrm{C}$ por 7 minutos (extensão final).

Os produtos da reação foram visualizados por eletroforese em gel de agarose $(1,2 \%)$ com TBE 0,5 X e corados com SYBR safe DNAGel Stain (Invitrogen). O marcador de peso molecular utilizado foi de $1 \mathrm{~Kb}$ DNA ladder (Invitrogen). A presença das bandas foi 
visualizada pela exposição dos géis à luz UV e fotografados por fotodocumentador Doc Print (Vilber Lourmat Biosystems, Paris, Lie-de-France, França).

\subsubsection{Purificação do fragmento}

O fragmento gerado foi purificado utilizando kit para purificação Qiaquick Spin Handbook (Qiagen, Hilden, Düsseldorf, Alemanha). Foram adicionados $250 \mu \mathrm{L}$ do tampão $\mathrm{PB}$ e $50 \mu \mathrm{L}$ da amostra em coluna de purificação. Foram submetidos à centrifugação a 10000 rpm por 1 minuto e o resíduo descartado. Foram adicionados $750 \mu \mathrm{L}$ do tampão PE, e as amostras centrifugadas por 1 minuto (10000 rpm). As colunas foram transferidas para um novo microtubo de $1,5 \mathrm{~mL}$ e as amostras eluídas com $50 \mu \mathrm{L}$ de tampão EB. Posteriormente, as amostras foram quantificadas e avaliadas quanto à pureza (valores aceitáveis de pureza maior ou igual a 1,8) utilizando o equipamento Nanodrop 2000C (Thermo Scientific Waltham).

\subsubsection{Reaç̃o de sequenciamento}

A reação de sequenciamento foi realizada em termociclador Thermocycler GeneAmp ${ }^{R} 9700$ (Applied Biosystems), utilizando $2 \mu \mathrm{L}$ do BigDye Terminator v3.3. (Applied Biosystems), $2 \mu \mathrm{L}$ do tampão para BigDye, $1 \mu \mathrm{L}$ do iniciador, mesmo utilizados na PCR (4 $\mu \mathrm{M}), 10 \mu \mathrm{L}$ de água Milli Q esterilizada e $1 \mu \mathrm{L}$ de DNA (10 a $20 \mathrm{ng}$ ). As condições da reação foram: $95{ }^{\circ} \mathrm{C}$ por 2 minutos, 25 ciclos de $96{ }^{\circ} \mathrm{C}$ por 20 segundos, $55^{\circ} \mathrm{C}$ (20 segundos) e $60{ }^{\circ} \mathrm{C}$ (4 minutos).

Após a reação, as amostras foram purificadas utilizando $40 \mu \mathrm{L}$ de isopropanol $60 \%$, em seguida, incubadas por 15 minutos a temperatura ambiente. Após centrifugação por $3000 \mathrm{rpm}$ (30 minutos), o sobrenadante foi descartado e $150 \mu \mathrm{L}$ de etanol $65 \%$ foram adicionados. $\mathrm{O}$ material foi centrifugado novamente a $3000 \mathrm{rpm}$ por 10 minutos, o sobrenadante descartado, este último passo foi repetido mais uma vez e, em seguida, o tubo foi seco em Concentrator (Eppendorf, Humburgo, Alemanha).

As amostras foram resuspendidas em formamida Hi-Di (Applied Biosystems), desnaturadas a $95{ }^{\circ} \mathrm{C}$ por 2 minutos e incubadas em gelo por 1 minuto. Em seguida foram aplicadas às colunas capilares contendo o polímero POP6 no sequenciador automático $A B I$ Prism ${ }^{R}$ Genetic Analyser (Applied Biosystems). As sequências foram editadas no software 
BioEdit v7.0.9.0 e alinhadas no Blast do Gene Bank (http://blast.ncbi.nlm.nih.gov/Blast.cgi) e no Fusarium ID v1.0 (http://isolate.fusariumdb.org/index.php) (GEISER et al., 2004).

\subsection{Análise filogenética das cepas de Fusarium verticillioides isoladas}

O estudo filogenético foi realizado utilizando-se o programa PAUP $4.0 \mathrm{~b} 10$, baseado no sequenciamento parcial do gene $T E F$ - $1 \alpha$. Apenas as regiões de exon foram utilizadas para construção do cladograma. O suporte dos nodos individuais foi verificado através da análise de bootstrap para 100 réplicas e o método utilizado foi o de distância com algoritmo neighbor-joining .

\subsection{Determinação de fumonisinas nos grãos de milho (VISCONTI; SOLFRIZZO; GIROLAMO, 2001)}

\subsubsection{Extracão e Purificação de fumonisinas das amostras}

A extração e purificação das fumonisinas foi realizada pelo método de Visconti et al. (2001) com algumas modificações. Foram transferidas para um frasco, $20 \mathrm{~g}$ de cada amostra previamente triturada e adicionados $100 \mathrm{~mL}$ de acetonitrila - metanol - água (25:25:50, v/v/v). Após agitação por 45 minutos, em agitador mecânico horizontal o sobrenadante foi filtrado em papel de filtro Whatman n ${ }^{\circ}$ 4, $12 \mathrm{~cm}$ (Sigma-Aldrich, St. Louis, Missouri, Estados Unidos). Foram pipetados $10 \mathrm{~mL}$ do filtrado e adicionados de $40 \mathrm{~mL}$ de tampão fosfato (PBS) pH 7,0 e agitados. Os extratos diluídos foram filtrados em papel de filtro de microfibra de 9 cm (Vicam, Milford, Massachusetts, USA) e, em seguida, coletados $10 \mathrm{~mL}$ para a purificação em coluna de imunoafinidade Fumonitest (Vicam) com fluxo de $1 \mathrm{~mL}$ por segundo. Posteriormente, a coluna foi lavada com $10 \mathrm{~mL}$ de PBS. As fumonisinas foram eluídas com 2 $\mathrm{mL}$ de metanol grau CLAE (Cromatografia Líquida de Alta Eficiência), evaporadas até resíduo e mantidas a $-20{ }^{\circ} \mathrm{C}$ até o momento da cromatografia.

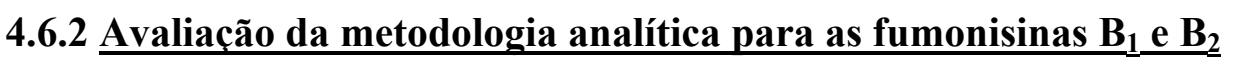

O método foi avaliado de acordo com os seguintes parâmetros: porcentagem de recuperação, limite de quantificação e limite de detecção. 
Duas curvas de calibração para cada fumonisina $\left(\mathrm{FB}_{1}\right.$ e $\left.\mathrm{FB}_{2}\right)$ foram construídas. Os valores foram: $0,3125,0,625,1,25,2,5,5,0$ e $10,0 \mu \mathrm{g} / \mathrm{mL}\left(1^{\mathrm{a}}\right.$ curva) e $0,039,0,078,0,156$ e $0,3125 \mu \mathrm{g} / \mathrm{mL}$ ( $2^{\mathrm{a}}$ curva). As soluções calibradoras de $\mathrm{FB}_{1}$ e $\mathrm{FB}_{2}$ foram preparadas em acetonitrila:água $(50: 50, \mathrm{v} / \mathrm{v})$ com uma concentração final de $50 \mu \mathrm{g} / \mathrm{mL}$ para $\mathrm{FB}_{1}$ e $\mathrm{FB}_{2}$. A partir desta as soluções foram diluídas para a obtenção das concentrações citadas para produção das curvas de calibração e verificação da linearidade.

Para análise da recuperação das fumonisinas foi realizada adição de quantidades conhecidas de $\mathrm{FB}_{1}$ e $\mathrm{FB}_{2}$ às amostras de milho com concentrações não detectáveis de fumonisinas, nas condições do experimento. Em $20 \mathrm{~g}$ de amostras de grãos de milho foram adicionados padrões de $\mathrm{FB}_{1}$ e $\mathrm{FB}_{2}$, em triplicata, nas concentrações de 15,0, 25,0, 50,0, 85,0, 150,0 e $300,0 \mu \mathrm{g} / \mathrm{kg}$. Em seguida, as amostras foram submetidas à metodologia de Visconti et al. (2001).

O limite de quantificação (LQ), foi determinado a partir da adição de quantidades decrescentes dos padrões às amostras com concentrações não detectáveis de toxinas (nas condições de nosso experimento), baseadas nas estimativas dos teores de fumonisinas no milho e do estudo da recuperação do método. A quantificação das amostras foi realizada através de curva de calibração.

\subsubsection{Cromatografia Líquida de Alta Eficiência}

Os extratos obtidos, foram resuspendidos em acetonitrila:água (50:50, v/v). Uma alíquota de $50 \mu \mathrm{L}$ da amostra foi diluída em $50 \mu \mathrm{L}$ da solução de reagente OPA para derivatização $(0,02 \mathrm{~g}$ de ortoftaldeído dissolvidos em $0,5 \mathrm{~mL}$ de metanol e diluídos em 2,5 $\mathrm{mL}$ de solução $0,1 \mathrm{M}$ e $25 \mu \mathrm{L}$ de mercaptoetanol; mantidos em temperatura ambiente protegidos da luz). Após 2 minutos de agitação, a reação foi injetada em cromatógrafo líquido (Shimadzu, modelo LC-10AD, Quioto, Quioto, Japão), equipado com injetor e "loop" fixo de $20 \mu \mathrm{L}$. Após a separação em coluna de fase reversa C-18 (5 ODS-20, 150 x 4,6 mm, Phenomenex, Torrence, Califórnia, Estados Unidos), os derivados das fumonisinas $\mathrm{B}_{1}$ e $\mathrm{B}_{2}$ presentes na solução foram detectados em detector de fluorescência (modelo RF-10AXL), com comprimentos de onda de 335 e $440 \mathrm{~nm}$ (excitação e emissão respectivamente). Como fase móvel foi utilizada, em modo isocrático, solução de acetonitrila:água:ácido acético $(49: 52: 2, \mathrm{v} / \mathrm{v} / \mathrm{v})$. A vazão foi de $1,4 \mathrm{~mL} / \mathrm{min}$ e a temperatura da coluna foi mantida em forno à $30{ }^{\circ} \mathrm{C}$, a temperatura da sala de $22-23{ }^{\circ} \mathrm{C}$. O tempo de retenção para $\mathrm{FB}_{1}$ e $\mathrm{FB}_{2}$ nestas 
condições foi de 7 minutos e 21 minutos, respectivamente. A quantificação das fumonisinas foi feita através da curva de calibração.

4.7 Avaliação do potencial toxigênico das cepas de $F$. verticillioides isoladas durante o estudo (ROSS et al., 1990 e ROSS et al., 1991).

Em frascos contendo $10 \mathrm{~g}$ de arroz autoclavado com $100 \mathrm{~mL}$ de água destilada, foram inoculados esporos das cepas de $F$. verticillioides, e incubados por 15 dias, a $25{ }^{\circ} \mathrm{C}$, seguido por outro período de 15 dias a $10^{\circ} \mathrm{C}$. As fumonisinas foram extraídas com $100 \mathrm{~mL}$ de metanol e água $(3: 1, v / v)$, com posterior agitação por $45 \mathrm{~min}$. As amostras foram então filtradas em papel de filtro (Whatman $\mathrm{n}^{\mathrm{o}} 4,12 \mathrm{~cm}$ ). A purificação das fumonisinas foi realizada transferindo-se $10 \mathrm{~mL}$ do filtrado para minicoluna contendo $500 \mathrm{mg}$ de sílica de troca-iônica BondElut SAX (Varian, Palo Alto, Califórnia, Estados Unidos), previamente condicionada com $5 \mathrm{~mL}$ de metanol e $5 \mathrm{~mL}$ de metanol:água $(3: 1, \mathrm{v} / \mathrm{v})$ em fluxo de $1 \mathrm{~mL} / \mathrm{min}$. Posteriormente foram lavadas com $5 \mathrm{~mL}$ metanol:água $(3: 1, \mathrm{v} / \mathrm{v})$ e $3 \mathrm{~mL}$ de metanol. Por fim, as fumonisinas foram eluídas com $2 \mathrm{~mL}$ de metanol:ácido acético $(99: 1, \mathrm{v} / \mathrm{v})$, mantendo a mesma taxa de fluxo. O produto da eluição foi evaporado até resíduo e separado por CLAE (SYDENHAM et al., 1996) e quantificado pela curva de calibração como realizado para determinação de fumonisinas no milho (item 3.6.3).

4.8 Análise da expressão dos genes FUM1, FUM3, FUM6, FUM7, FUM8, FUM10, FUM11, FUM12, FUM13, FUM14, FUM15, FUM16, FUM17, FUM18, FUM19 $e$ $F U M 21$ em grãos de milho Bt por $q P C R$

\subsubsection{Desenho dos iniciadores}

Os iniciadores foram desenhados utilizando o programa Primer 3 (http://frodo.wi.mit.edu/primer3/) a partir da sequência U27303.1 depositada no NCBI (http://www.ncbi.nlm.nih.gov/) (Tabela 1). A figura A.1 (APÊNDICE A) demonstra as curvas de dissociação para cada par de primer testado. 
Tabela 1. Iniciadores utilizados para a da amplificação do cDNA na reação de qPCR.

\begin{tabular}{|c|c|c|c|}
\hline Genes & & Sequência & $\begin{array}{l}\text { Tamanho do fragmento } \\
(\mathrm{pb})\end{array}$ \\
\hline \multirow{2}{*}{ FUM1 } & $\mathbf{F}$ & 5'- GAGCCGAGTCAGCAAGGATT - -3' & \multirow{2}{*}{90} \\
\hline & $\mathbf{R}$ & 5'-AGGGTTCGTGAGCCAAGGA-3' & \\
\hline \multirow{2}{*}{ FUM2 } & $\mathbf{F}$ & 5'-TCCAGACGCTTGGAAAGATA-3' & \multirow{2}{*}{100} \\
\hline & $\mathbf{R}$ & 5'-GCTGGGAACATCATCATCG-3' & \\
\hline \multirow{2}{*}{ FUM6 } & $\mathbf{F}$ & 5'-GATAGACTCGGGGCTGAGA-3' & \multirow{2}{*}{100} \\
\hline & $\mathbf{R}$ & 5'-AGCTCGCCGACAGAATC-3' & \\
\hline \multirow{2}{*}{ FUM7 } & $\mathbf{F}$ & 5'-CATCGTATCTACATTGTCGCATC- $3^{\prime}$ & \multirow{2}{*}{100} \\
\hline & $\mathbf{R}$ & 5'-TGTACTCTCCAACAATATGAATGAGTC-3' & \\
\hline \multirow[b]{2}{*}{ FUM8 } & $\mathbf{F}$ & 5'-CAACAGAAATACGCAATGACG-3' & \multirow[b]{2}{*}{99} \\
\hline & $\mathbf{R}$ & 5'-TGCTCGACCACTACATCAGG-3' & \\
\hline \multirow{2}{*}{ FUM9 } & $\mathbf{F}$ & 5'-CTTGGCGGTGCCCATACTA-3' & \multirow{2}{*}{97} \\
\hline & $\mathbf{R}$ & 5'-GGACCAAGAGCGTGGATG-3' & \\
\hline \multirow[b]{2}{*}{ FUM10 } & $\mathbf{F}$ & 5'-GCAACGTGCCATTTCAGC-3' & \multirow{2}{*}{100} \\
\hline & $\mathbf{R}$ & 5'-AGGCATCACAGCAACCAGAT-3' & \\
\hline \multirow{2}{*}{ FUM11 } & $\mathbf{F}$ & 5'-CCTCTCGCGCAGATGAAT-3' & \multirow{2}{*}{100} \\
\hline & $\mathbf{R}$ & 5'-TCACGGTTTATCTGACACAGC-3' & \\
\hline \multirow{2}{*}{ FUM13 } & $\mathbf{F}$ & 5'-GCCTTTGGTCTTGTTCTCTCA-3' & \multirow{2}{*}{100} \\
\hline & $\mathbf{R}$ & $\begin{array}{l}5^{\prime} \text {-CGTCAATTATTGCCTCTTTCAA-3' } \\
\end{array}$ & \\
\hline \multirow{2}{*}{ FUM14 } & $\mathbf{F}$ & 5'-TAGGTCCAGGTCGAGATGCT-3' & \multirow{2}{*}{99} \\
\hline & $\mathbf{R}$ & 5'-GGAAGCCAAGAACCCAATCT-3' & \\
\hline \multirow{2}{*}{ FUM15 } & $\mathbf{F}$ & $\begin{array}{l}5^{\prime} \text {-TGCCATCCAGAATGACGATA-3' } \\
\end{array}$ & \multirow{2}{*}{94} \\
\hline & $\mathbf{R}$ & 5'-GAGTCTCAGGAGAGCGAGGA-3' & \\
\hline \multirow[b]{2}{*}{ FUM16 } & $\mathbf{F}$ & 5'-TCCTGATGGTCTCCCAAATC-3' & \multirow[b]{2}{*}{92} \\
\hline & $\mathbf{R}$ & 5'-TGATGCCTCTCTCCGAGAAT-3' & \\
\hline \multirow{2}{*}{ FUM17 } & $\mathbf{F}$ & $\begin{array}{l}5^{\prime} \text {-ATGGGATGGCATTTCCAGTA-3' } \\
\end{array}$ & \multirow{2}{*}{89} \\
\hline & $\mathbf{R}$ & 5'-GGCGAGAAATAGAGCATTGG-3' & \\
\hline \multirow[b]{2}{*}{ FUM18 } & $\mathbf{F}$ & 5'-CATGAGAATCCAGCCCTGTT-3' & \multirow[b]{2}{*}{89} \\
\hline & $\mathbf{R}$ & 5'-AATACCTCCTTGCCCCATTC-3' & \\
\hline \multirow{2}{*}{ FUM19 } & $\mathbf{F}$ & 5'-ATCAGCATCGGTAACGCTTATGA-3' & 88 \\
\hline & $\mathbf{R}$ & 5'-CGCTTGAAGAGCTCCTGGAT-3' & 88 \\
\hline & $\mathbf{F}$ & 5'-TAATGGATCAGCGGAAGAGT-3' & \\
\hline FUM121 & $\mathbf{R}$ & 5'-TGCCTCAGTATTAGTCGTACAGTCA-3' & 100 \\
\hline & $\mathbf{F}$ & 5'-CCGGTATGGGTACTCTGCTC-3' & \\
\hline TUB & $\mathbf{R}$ & 5'-CTCAACGACGGTGTCAGAGA-3' & 95 \\
\hline & $\mathbf{R}$ & 5'-TCAGCCTCTCGGATCATCTC- $3^{\prime}$ & \\
\hline
\end{tabular}

\subsubsection{Validação da técnica de PCR em tempo real para os genes FUM}

A quantificação relativa baseada nos valores de $\Delta \Delta \mathrm{Ct}$ foi a metodologia analítica de escolha para esse estudo. Foram testados os genes de referência: fator de elongação $1 \alpha$, calmodulina, 18S do rRNA e $\beta$ tubulina. Os testes para validação foram realizados em triplicata, a partir da extração do RNA utilizando-se o kit RNAqueous (Ambion, Austin, Texas, Estados Unidos) de uma cepa padrão de F. verticillioides MAT A- 1 (Medical Resource Council - África do Sul), crescidas em caldo Czapek durante 7 dias. As amostras de cDNA obtidas (KitSensiscript RT - Qiagen) foram diluídas $(1 ; 1: 10 ; 1: 100 ; 1: 1000)$ e submetidas à PCR em tempo real para a construção da curva de calibração para os genes FUM. A partir da 
curva gerada pelo equipamento, foi calculada a eficiência do ensaio através da fórmula: $E=10$ (-1/slope) -1 para cada gene.

Foi realizado o teste de compatibilidade, em triplicata, entre cada gene alvo (FUM) e o gene de referência que apresentou melhor valor de eficiência (tubulina). A comparação foi realizada entre o valor médio do $\mathrm{Ct}$ do gene alvo e valor médio do $\mathrm{Ct}$ do gene de referência selecionado. Realizou-se a subtração do $\mathrm{Ct}$ do gene alvo e Ct do gene de referência, obtendose o $\Delta$ Ct. Estes valores foram plotados em um gráfico, em que o eixo y correspondia aos valores de $\Delta \mathrm{Ct}$, e o eixo x o log dos valores da diluição, para o cálculo do slope da reta gerada, que deve ser entre -0,1 e 0,1 (PFAFFL, 2001; SCHMITTGEN; LIVAK, 2008).

\subsubsection{Isolamento do RNA e transcrição reversa}

O RNA total foi isolado utilizando os Kits: RNAid e RNAqueous (Ambion), de acordo com o manual de instruções. O uso de dois kits para extração do RNA de Fusarium a partir dos grãos, se deve à elevada presença de interferentes nos grãos de milho, o que dificulta a obtenção de uma concentração adequada de RNA para realização do experimento. Em seguida, o RNA total extraído foi submetido ao Kit DNAse Turbo DNA-Free (Ambion), seguindo instruções do fabricante, para retirada de eventuais fragmentos de DNA, e logo em seguida, o cDNA foi sintetizado utilizando o High Capacity Reverse Transcription Kit (Applied Biosystems). Cada $160 \mu \mathrm{L}$ de reação continha $80 \mu \mathrm{L}$ do produto de extração de RNA total, $10 \mu \mathrm{L}$ de Random primers ( $3 \mu \mathrm{g} / \mu \mathrm{L}$ - Applied Biosystems), $10 \mu \mathrm{L}$ de 10X RT-PCR buffer, $10 \mu \mathrm{L}$ de dNTP mix, $6 \mu \mathrm{L}$ de inibidor de RNAse (40 U/ $\mu \mathrm{L}$ - Invitrogen), $2 \mu \mathrm{L}$ de High-Capacity Reverse Transcriptase e água DPEC (Invitrogen) estéril qsp. A síntese do cDNA foi realizada em termociclador Applied Biosystems Thermocycler Gene Amp ${ }^{R}$ PCR System 9700 por $1 \mathrm{~h}$ a $37^{\circ} \mathrm{C}$. As amostras foram mantidas a $-20^{\circ} \mathrm{C}$.

\subsubsection{Ensaio SPUD para deteccão de inibidores nas amostras de ácido nucléico (NOLAN} et al., 2006).

Com a finalidade de identificar a presença de inibidores nas amostras de RNA extraídas dos grãos de milho que possam interferir negativamente nas reações de PCR, foi utilizado o método denominado Ensaio SPUD. Este ensaio consiste na amplificação do amplicon SPUDA, uma sequência de 101 pares de bases pertencente ao gene phyB de Solanum tuberosum que codifica uma proteína espécie específica. Uma solução contendo 20 mil cópias $/ \mu \mathrm{L}$ do 
amplicom SPUD-A (usando o NanoDrop para determinação da concentração), foi utilizada como amostra para reação de PCR em tempo real, primers forward e reverse (tabela 2), denominados respectivamente SPUD-F e SPUD-R a $240 \mathrm{nM}$ e o reagente Platinum SYBER Green qPCR SuperMix - UDG (Invitrogen) foram utilizados nas reações. Para padronização do ensaio, amplificações em triplicata foram feitas com um volume total de $25 \mu \mathrm{L}$.

Tabela 2. Iniciadores utilizados para a realização do Ensaio SPUD e sequência SPUD-A.

\begin{tabular}{|c|c|}
\hline SPUD & Sequência \\
\hline SPUD-F & 5'-AACTTGGCTTTAATGGACCTCCA -3' \\
\hline SPUD-R & 5'-ACATTCATCCTTACATGGCACCA-3' \\
\hline SPUD-A & 5'AACTTGGCTTTAATGGACCTCCAATTTTGAGTGTGCACAAGCTATGGAACAC \\
& CACGTAAGACATAAAACGGCCACATATGGTGCCATGTAAGGATGAATGT-3' \\
\hline
\end{tabular}

Resumidamente, cada reação conteve $1 \mu \mathrm{L}$ de cada primer, $10 \mu \mathrm{L}$ SYBER Green, $0,5 \mu \mathrm{L}$ de ROX, 12,5 $\mu \mathrm{L}$ de água DEPEC (Invitrogen) estéril e $1 \mu \mathrm{L}$ de SPUD-A. Já para realização do ensaio com as amostras de cDNA, cada reação de $25 \mu \mathrm{L}$ conteve $1 \mu \mathrm{L}$ de cada primer, 10 $\mu \mathrm{L}$ SYBER Green, 0,5 $\mu \mathrm{L}$ de ROX, 7,5 $\mu \mathrm{L}$ de água DEPEC (Invitrogen) estéril e $1 \mu \mathrm{L}$ de SPUD-A e $5 \mu \mathrm{L}$ da amostra de cDNA. O controle positivo foi realizado com $5 \mu \mathrm{L}$ de água no lugar da amostra de cDNA. A termociclagem consistiu em 2 minutos a $95{ }^{\circ} \mathrm{C}$ para ativação da Taq e 40 ciclos a $95{ }^{\circ} \mathrm{C}$ por 15 segundos e $60{ }^{\circ} \mathrm{C}$ por 30 segundos. $\mathrm{O} \mathrm{Ct}$ esperado neste ensaio para amostras que não contém inibidores suficientes para inibição da reação de PCR é entre 23 a 25. As amostras cujo Ct de amplificação do SPUD-A ficaram fora desse limite tiveram seu RNA re-extraídos e analisados pelo ensaio SPUD-A novamente.

\subsubsection{Análise por qPCR}

A PCR em tempo real baseada nos genes FUM1, FUM2, FUM6, FUM7, FUM8, FUM9, FUM10, FUM11, FUM13, FUM14, FUM15, FUM16, FUM17, FUM18, FUM19 e FUM21de F. verticillioides foi realizada pela utilização dos iniciadores obtidos a partir do programa Primer 3. As condições para a termociclagem foram: $50{ }^{\circ} \mathrm{C}$ por 2 minutos, $95{ }^{\circ} \mathrm{C}$ por 2 minutos, 40 ciclos a $95{ }^{\circ} \mathrm{C}$ por 15 segundos, e $60{ }^{\circ} \mathrm{C}$ por 30 segundos. O reagente Platinum SYBR Green qPCR SuperMix - UDG (Invitrogen) foi utilizado na reação, adicionando 5,5 $\mu \mathrm{L}$ de água Milli Q estéril, $2.0 \mu \mathrm{L}$ de cada iniciador e $5 \mu \mathrm{L}$ da fita de cDNA, $10 \mu \mathrm{L}$ do reagente Syber e $0.5 \mu \mathrm{L}$ de ROX, totalizando um volume de $25 \mu \mathrm{L}$. As reações foram realizadas no equipamento Step One Plus Real - Time PCR Systems (Applied Biosystems). Para a exclusão 
de possíveis contaminações, em todas as reações, foi utilizado um controle negativo apropriado. A quantificação do RNAm foi normalizada utilizando os valores de Ct do gene de referência tubulina. As diferenças nos níveis de expressão dos genes responsáveis pela biossíntese das fumonisinas nas amostras das diferentes coletas foram verificados pela metodologia de $\Delta \Delta \mathrm{Ct}$, através da subtração do $\Delta \mathrm{Ct}$ da amostra calibradora em relação a outra amostra. Os valores de $\Delta \Delta \mathrm{Ct}$ foram transformados em $\log 2$ para gerar os níveis de expressão relativa (GIZINGER, 2002). Estes valores foram visualizados pelo programa $R q$ Study disponível no equipamento Step One Plus (Applied Biosystems).

\subsection{Análise dos Fatores Climatológicos nos períodos das diferentes coletas}

Os dados referentes à umidade relativa média do ar $(\%)$, temperatura média $\left({ }^{\circ} \mathrm{C}\right)$ e índice pluviométrico $(\mathrm{mm})$ durante o período da semeadura dos grãos à colheita foram fornecidos pelo Instituto Nacional de Meteorologia (Inmet). As médias dos valores relativos à cada coleta estão apresentados na tabela 3 .

Tabela 3. Valores médios das variáveis climatológicas no período anterior a cada uma das fases*.

\begin{tabular}{|l|l|l|l|}
\hline Fase & Temperatura $\left({ }^{\circ} \mathbf{C}\right)$ & $\begin{array}{l}\text { Umidade Relativa } \\
\text { do ar (\%) }\end{array}$ & Precipitação (mm) \\
\hline Florescimento & 23,7 & 73,7 & 1,9 \\
\hline Grão leitoso & 24,7 & 75,6 & 9,8 \\
\hline Grão Pastoso & 24,3 & 76,9 & 5,7 \\
\hline Grão farináceo & 23,7 & 81,5 & 16,5 \\
\hline Farináceo duro & 24,8 & 76,3 & 17,9 \\
\hline Maturidade & 24,5 & 75,9 & 15,0 \\
\hline Colheita final & 24,7 & 75,6 & 5,6 \\
\hline \multicolumn{2}{|r}{${ }^{*}$ Entre o dia posterior a uma coleta e o dia anterior a coleta seguinte. } \\
\hline
\end{tabular}

\subsection{Análises Estatísticas (RIGBY; STASINOPOULOS, 2005)}

As análises estatísticas foram feitas com a utilização dos softwares R 2.9 pacote Gamlss e SAS 9.1, em todos os modelos o nível de significância considerado foi de $5 \%$.

A análise inferencial compreende 3 fases distintas. Na primeira fase, foi analisada o efeito do período de desenvolvimento dos grãos de milho, da atividade de água e de variáveis 
climatológicas no crescimento de $F$. verticillioides e na produção de $\mathrm{FB}_{1}$ e $\mathrm{FB}_{2}$. Na segunda fase foi analisada o efeito do valor da expressão relativa dos genes $F U M$ (dados apresentados no segundo relatório parcial) na porcentagem de isolamento de $F$. verticillioides e na quantidade de fumonisinas $\mathrm{FB}_{1}$ e $\mathrm{FB}_{2}$ detectadas nos grãos de milho. Na terceira fase a hipótese de que a probabilidade de amplificar todos os genes $F U M$ varia em função da fase de desenvolvimento do milho e da porcentagem de isolamento de $F$. verticillioides foi testada. Os dados da porcentagem de isolamento de $F$. verticillioides e da atividade de água encontrada foram apresentados no primeiro relatório parcial, enquanto que os dados da expressão relativa do genes $F U M$ foram apresentados no segundo relatório parcial.

\subsubsection{Fase 1: Efeito das variáveis na porcentagem de isolamento de $F$. verticillioides e na contaminação por $F_{B} \underline{\text { e }}_{2} \underline{B}_{2} \underline{\text { nos grãos de milho }}$}

A distribuição da variável resposta foi escolhida utilizando gráficos de resíduos quantílicos. Para a frequência de isolamento de $F$. verticillioides foi utilizado o modelo beta binomial, para contaminação por $\mathrm{FB}_{1}$ foi utilizado o modelo gaussiana inversa e para $\mathrm{FB}_{2}$ foi utilizado o modelo gama inflacionado no zero. As variáveis preditoras consideradas no modelo foram: período de desenvolvimento do grão, atividade de água, temperatura, umidade e precipitação. Para os modelos para contaminação por $\mathrm{FB}_{1}$ e $\mathrm{FB}_{2}$ foi incluída adicionalmente a variável porcentagem de isolamento de $F$. verticillioides dos grãos de milho.

\subsubsection{Fase 2: efeito do valor da expressão relativa dos genes FUM na porcentagem de isolamento de $F$. verticillioides e na quantidade de fumonisinas $F_{B} \underline{B}_{1} \mathrm{FB}_{2}$ detectadas nos grãos de milho}

Para estes estudos foram utilizados os mesmos modelos descritos no item 3.10.1. Para isso, para cada variável resposta significante de cada modelo, testou-se uma a uma, se a distribuição desta variável resposta variava em função do valor de expressão relativa dos genes FUM. A partir disso, inseriu-se no modelo a variável com menor valor-p e repetiu-se o processo até que nenhuma variável tivesse valor-p inferior a 0,05 . 
4.10.3 Fase 3: probabilidade de amplificar todos os genes $F U M$ variar em função da fase de desenvolvimento do milho e da porcentagem de isolamento de $F$. verticillioides

Para esta fase, foi ajustado o modelo de regressão logística (HOSMER; LEMESHOW, 2000) e para testar entre que fases do desenvolvimento do milho há diferença em relação à probabilidade de amplificação de todos os genes $F U M$, foram realizadas comparações múltiplas (NETER et al., 1996). 


\section{RESULTADOS}

\subsection{Micobiota}

Os resultados referentes à pesquisa da micobiota das 364 amostras de grãos de milho provenientes das sete coletas demonstram contaminação fúngica em $100 \%$ das amostras de milho analisadas.

$\mathrm{Na}$ primeira coleta (estádio R1), realizada na fase de florescimento, os grãos revelaram atividade de água média de 0,99. Os fungos isolados, em ordem decrescente de frequência, foram (Tabela B.1 e Figura 10): leveduras (100,0\%), Penicillium spp. (57,8\%), fungos não esporulados (FNE) (34,62\%), Geotrichum spp. (28,85\%), Cladosporium spp. (23,08\%), Aspergillus spp. (13,46\%), Fusarium spp. (11,54\%), Neurospora spp. (11,54\%), Acremonium spp. (9,62\%), Rhizopus (9,62\%), Mucor spp. (7,59\%), Trichoderma spp. (3,85\%), Nigrospora spp. (3,85\%), Curvularia spp. (1,92\%) e Alternaria spp. (1,92\%).

Figura 10. Frequência relativa (\%) de isolamento dos diferentes fungos em 52 amostras de grãos de milho da coleta 1, provenientes do município de Cruzália, estado de São Paulo.

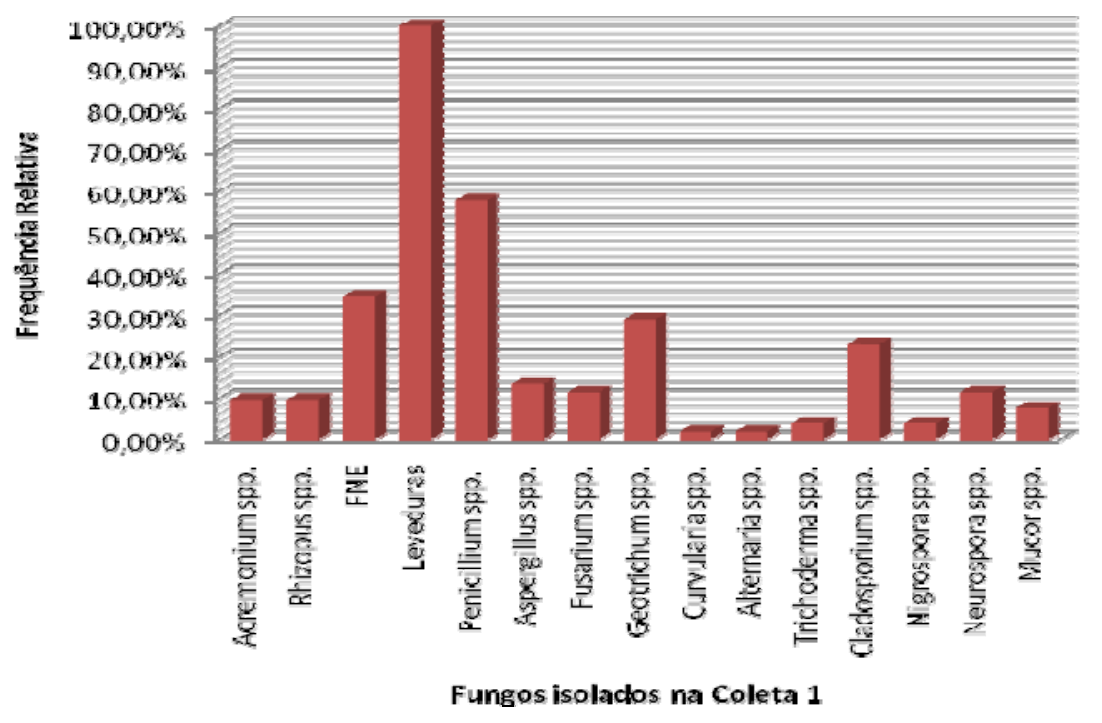

Em relação ao gênero Fusarium, foram isoladas as seguintes espécies: F. verticillioides $(9,06 \%), F$. subglutinans (3,85\%) e F. anthophilum (1,92\%) (Figura 11). 
Figura 11. Frequência relativa (\%) de isolamento das diferentes espécies de Fusarium das amostras de grãos de milho das sete coletas, provenientes do município de Cruzália, estado de São Paulo.

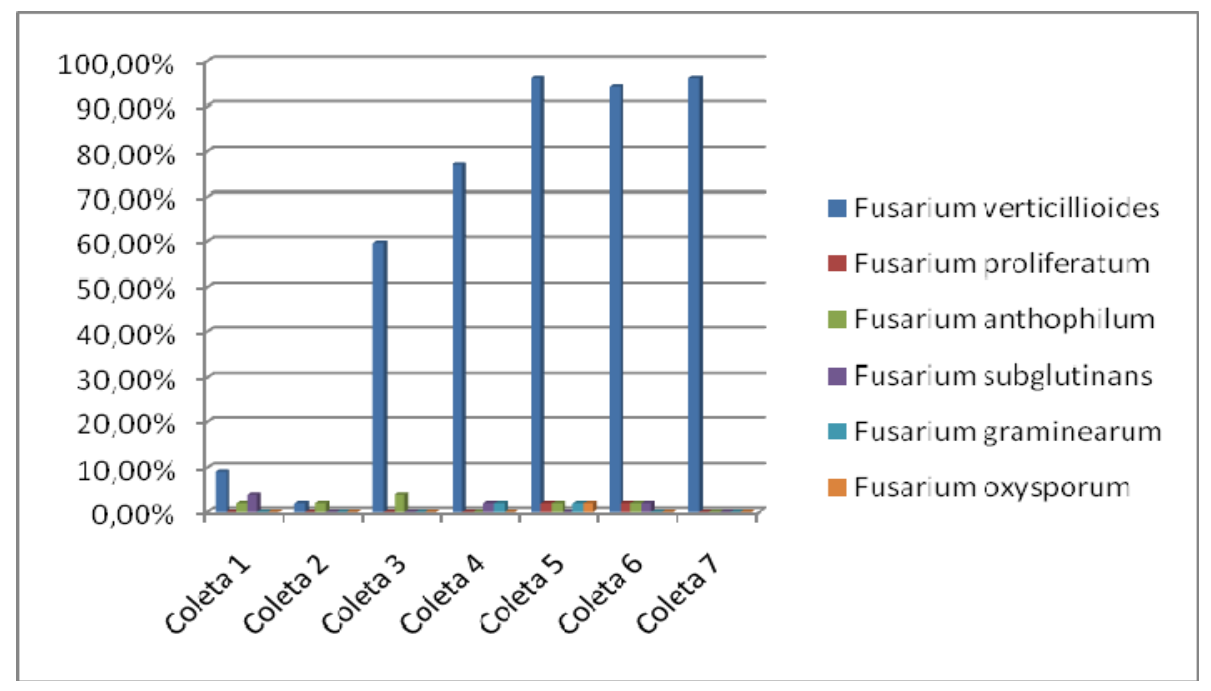

A segunda coleta foi realizada no estádio R2, denominado fase de grão leitoso, que se dá de 10 a 14 dias após o florescimento. Nesse estádio, a atividade de água variou de 0,97 a 0,99 entre as amostras. Os fungos isolados foram (Tabela B.2 e Figura 12): leveduras (100\%), Geotrichum spp. (78,85\%), Penicillium spp. (26,92\%), FNE (26,92\%), Rhizopus spp. (26,92\%), Aspergillus spp. (23,08\%), Mucor spp. (21,15\%), Cladosporium spp. (19,23\%), Alternaria spp. (11,54\%), Neurospora spp. (7,69\%), Trichoderma spp. (5,77\%), Fusarium spp. (3,85\%), Acremonium spp. (1,92\%), Nigrospora spp. (1,92\%) e Curvularia spp. (1,92\%).

Figura 12. Frequência relativa (\%) de isolamento dos diferentes fungos em 52 amostras de grãos de milho da coleta 2, provenientes do município de Cruzália, estado de São Paulo.

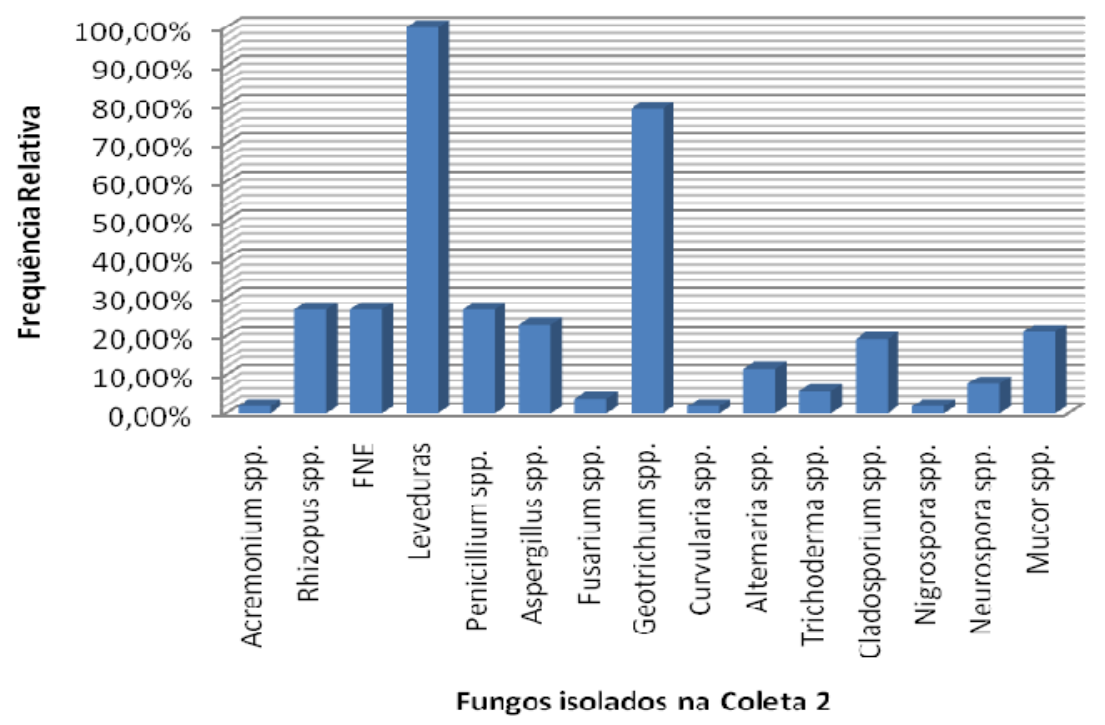


As espécies de Fusarium isoladas foram: F. verticillioides (1,92\%) e F. anthophilum $(1,92 \%)$ (Figura 11).

A terceira coleta foi realizada no estádio R3, denominado fase de grão pastoso, ocorre entre 18 a 22 dias após florescimento. Nesse estádio, a atividade de água variou de 0,96 a 0,98. Foram isolados os seguintes fungos (Tabela B.3 e Figura 13): leveduras (100\%), Fusarium spp. (63,46\%), Cladosporium spp. (51,92\%), Penicillium spp. (44,23\%), FNE (21,15\%), Geotrichum spp. (19,23\%), Rhizopus (17,31\%), Trichoderma spp. (13,46\%), Acremonium spp. (13,46\%), Aspergillus spp. (7,69\%), Alternaria spp. (1,92\%), Nigrospora spp. (1,92\%), Neurospora spp. (1,92\%) e Mucor spp. (1,92\%). Com relação à Fusarium, foram observadas as espécies $F$. verticillioides (59,62\%) e F. anthophilum (3,85\%) (Figura 11).

Figura 13. Frequência relativa (\%) de isolamento dos diferentes fungos em 52 amostras de grãos de milho da coleta 3, provenientes do município de Cruzália, estado de São Paulo.

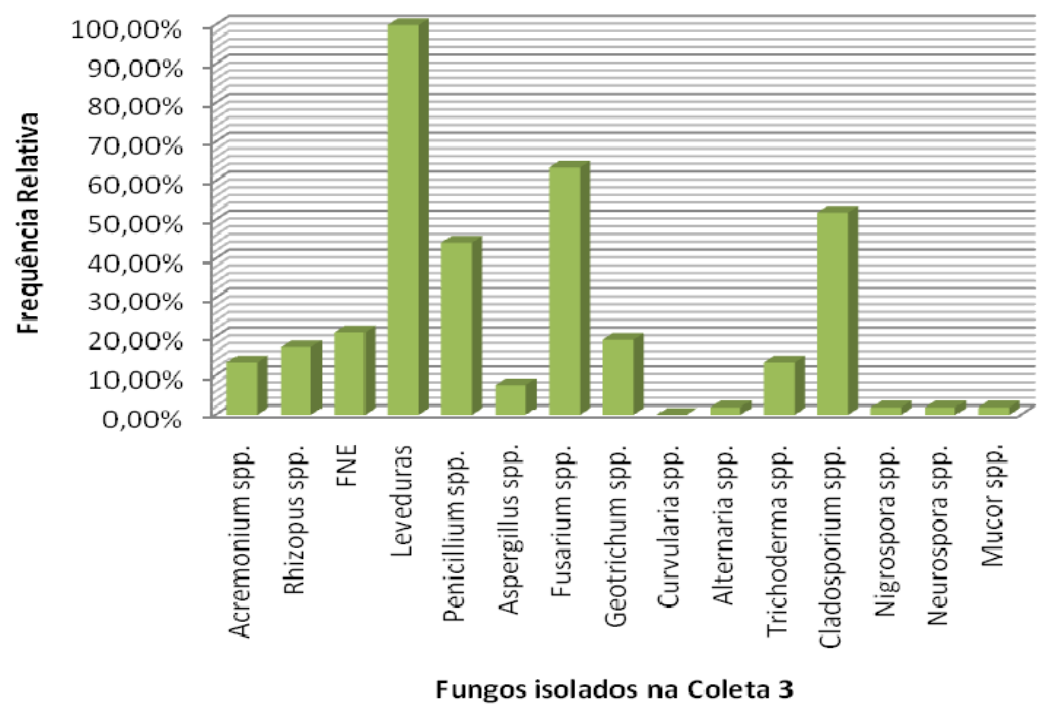

A quarta coleta foi realizada no estádio R4, denominado grão farináceo, que ocorre entre 24 a 28 dias após florescimento. Nesse estádio a atividade de água média foi de 0,96. Foram observados os fungos (Tabela B.4 e Figura 14): leveduras (100\%), Fusarium spp. (78,85\%), Cladosporium spp. (67,31\%), Trichoderma spp. (30,77\%), Penicillium spp. (28,85\%), Geotrichum spp. (28,85\%), FNE (19,33\%), Aspergillus spp. (9,62\%), Neurospora spp. (3,85\%), Nigrospora spp. (1,92\%) e Mucor spp. (1,92\%). As espécies de Fusarium isoladas foram: $F$. verticillioides $(76,92 \%), F$. subglutinans $(1,92 \%)$ e $F$. graminearum $(1,92 \%)$ (Figura 11). 
Figura 14. Frequência relativa (\%) de isolamento dos diferentes fungos em 52 amostras de grãos de milho da coleta 4, provenientes do município de Cruzália, estado de São Paulo.

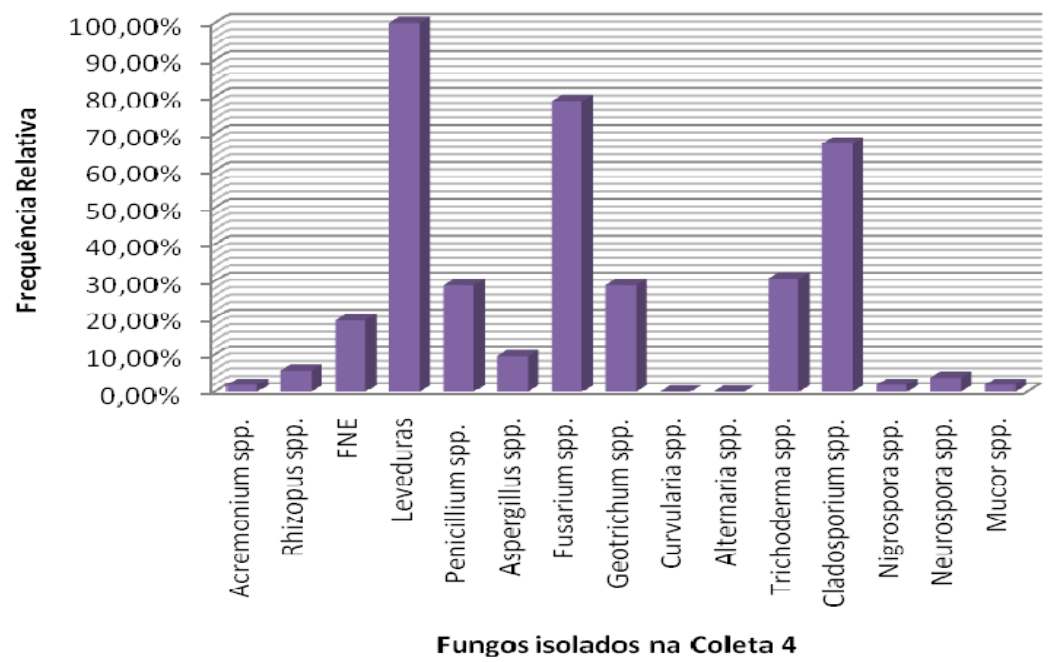

A quinta coleta foi realizada no estádio R5, denominado de fase de grão farináceo-duro, que se inicia entre 35 a 42 dias após o florescimento. Nesse estádio a atividade de água média foi de 0,97. Os fungos isolados foram (Tabela A.5 e Figura 15): Fusarium spp. (98,08\%), leveduras (88,46\%), Cladosporium spp. (61,54\%), Penicillium spp. (25\%), FNE (19,23\%), Trichoderma spp. (13,46\%), Geotrichum spp. (5,77\%), Acremonium spp. (3,85\%), Rhizopus spp. (3,85\%), Aspergillus spp. (3,85\%) e Neurospora spp. (1,92\%). As espécies de Fusarium encontradas foram: $F$. verticillioides $(96,15 \%), F$. proliferatum $(1,92 \%), F$. graminearum $(1,92 \%)$ e $F$. oxysporum $(1,92 \%)$ (Figura 11$)$. 
Figura 15. Frequência relativa (\%) de isolamento dos diferentes fungos em 52 amostras de grãos de milho da coleta 5.

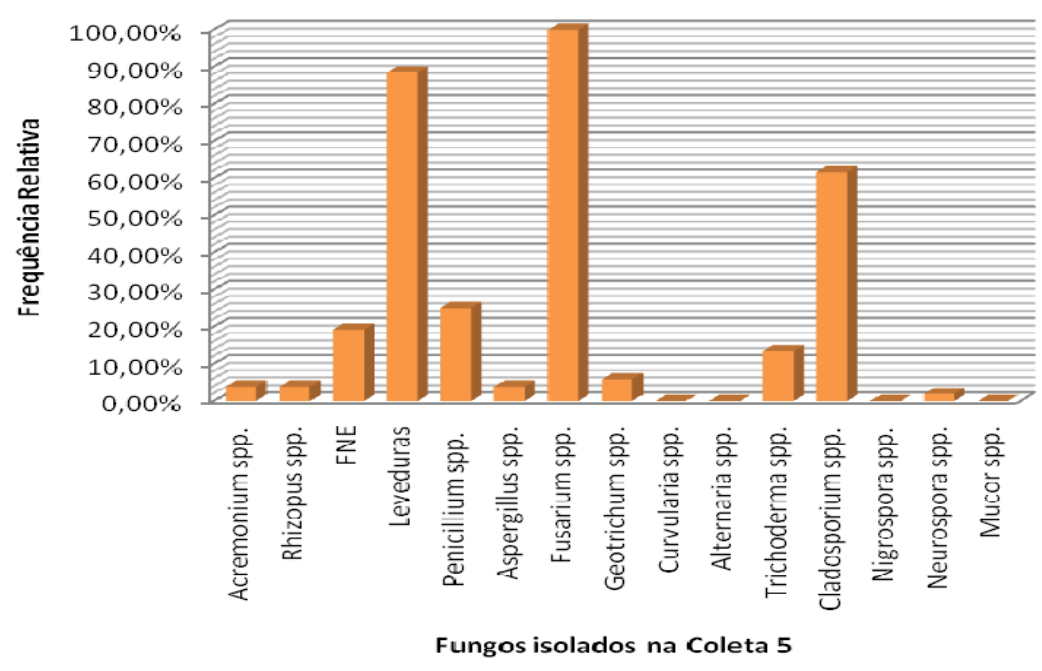

A sexta coleta foi realizada no estádio R6, denominado de fase de grão em maturidade fisiológica, que se inicia entre 55 a 65 dias após o florescimento. Nesse estádio a atividade de água média dos grãos foi de 0,96. Os fungos encontrados foram (Tabela B.6 e Figura 16): Fusarium spp. (100\%), Penicillium spp. (84,62\%), FNE (73,08\%), Cladosporium spp. (73,08\%), leveduras (71,15\%), Aspergillus spp. (36,54\%), Trichoderma spp. (21,15\%), Neurospora spp. (7,69\%), Geotrichum spp. (5,77\%), Mucor spp. (5,77\%) e Acremonium spp. (3,85\%). As espécies de Fusarium encontradas foram: $F$. verticillioides $(94,23 \%), F$. proliferatum (1,92\%), F. anthophilum (1,92\%) e F. subglutinans (1,92\%) (Figura 11).

Figura 16. Frequência relativa (\%) de isolamento dos diferentes fungos em 52 amostras de grãos de milho da coleta 6, provenientes do município de Cruzália, estado de São Paulo.

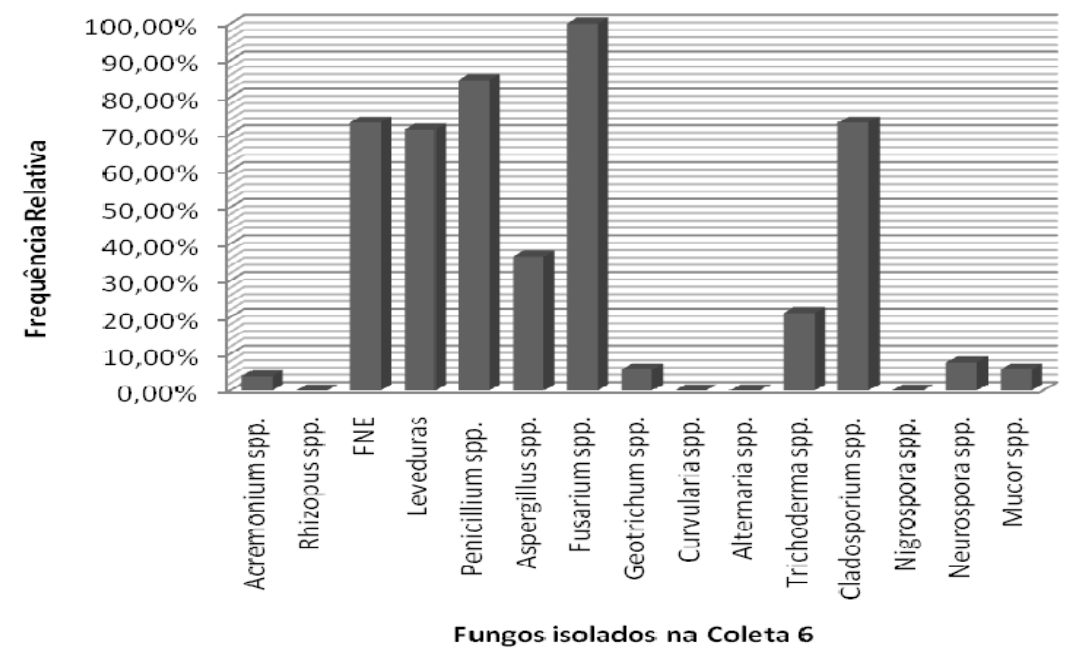

A sétima e última coleta foi realizada 3 semanas após a maturidade fisiológica, quando ocorreu a colheita final pelo agricultor (C7). A atividade de água média foi de 0,96. Os fungos 
isolados nesta fase foram (Tabela B.7 e Figura 17): Penicillium spp. (100\%), Fusarium spp. (96,15\%), leveduras (38,46\%), Trichoderma spp. (32,69\%), Nigrospora spp. (11,64\%), Cladosporium spp. (7,69\%), FNE (7,69\%), Aspergillus spp. (3,85\%), Neurospora spp. (3,85\%), Acremonium spp. (1,92\%). A única espécie de Fusarium encontrada foi $F$. verticillioides $(96,15 \%)$ (Figura 11).

Figura 17. Frequência relativa (\%) de isolamento dos diferentes fungos em 52 amostras de grãos de milho da coleta 7, provenientes do município de Cruzália, estado de São Paulo.

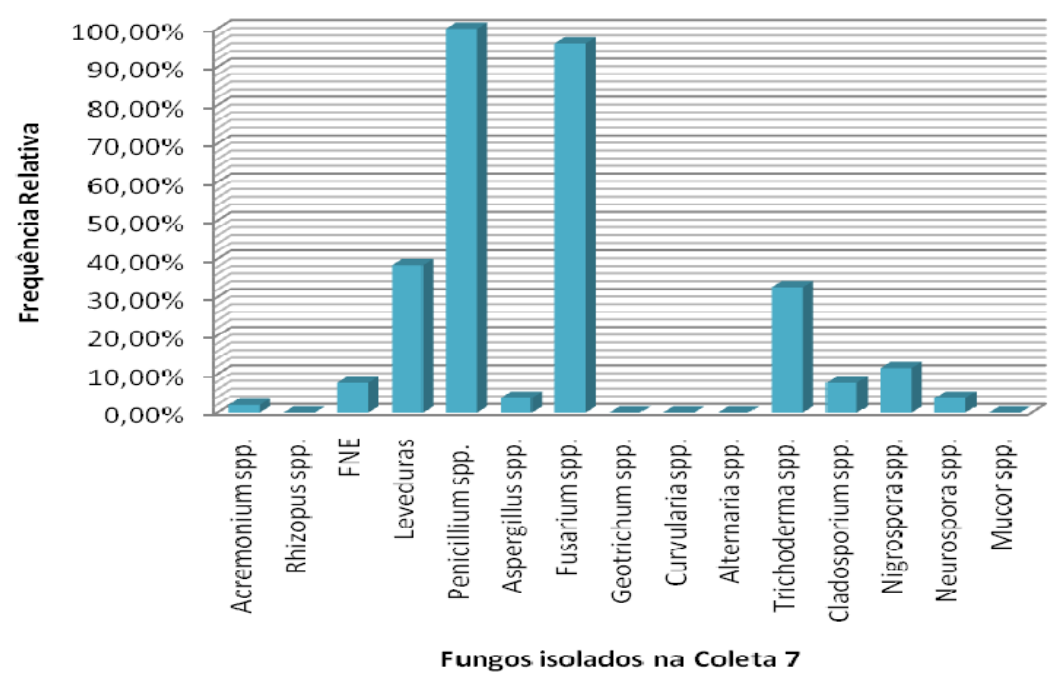

\subsection{Análise filogenética das cepas de Fusarium verticillioides isoladas}

Das 257 cepas de Fusarium isoladas neste trabalho, 243(94,5\%) foram identificadas como $F$. verticillioides, utilizando sequenciamento parcial do gene TEF- $1 \alpha$. Das cepas identificadas, 6 foram isoladas na $1^{\text {a }}$ coleta; 1 cepa foi isolada na $2^{\text {a }}$ coleta; 32 cepas isoladas na $3^{\mathrm{a}}$ coleta; 44 cepas isoladas na $4^{\mathrm{a}}$ coleta; 53 cepas isoladas na $5^{\mathrm{a}}$ coleta; 57 cepas isoladas na $6^{\mathrm{a}}$ coleta e 50 cepas da $7^{\mathrm{a}}$ coleta. Foram utilizadas, para construção da árvore filogenética, as sequências com maior qualidade possível no sequenciamento, totalizando 157 sequências, a saber: 4 cepas da coleta 1 (C1), 1 cepa da coleta 2 (C2), 26 cepas da coleta 3 (C3), 32 cepas da coleta 4 (C4), 37 cepas da coleta 5 (C5), 28 cepas da coleta 6 (C6) e 29 cepas da coleta 7 (C7).

Foram formados 6 grupos bem distintos no cladograma (Figura A.2 - APÊNDICE A):

- Grupo 1 (G1), formado por 22 cepas (4 cepas da C1, uma cepa da C2, 9 cepas da C3, 3 cepas da C4, 2 cepas da C5, uma cepa da C6 e 2 cepas da C7). 
- Grupo 2 (G2), contém 37 cepas, sendo, portanto, o maior grupo (2 cepas de C3, 9 de C4, 5 de C5, 12 de C6 e 9 cepas de C7);

- Grupo 3 (G3), formado por 22 (3 de C3, 4 de C4, 2 de C5, 5 de C6 e 8 de C7);

- Grupo 4 (G4) contém 13 cepas (2 de C3, 6 de C4, 2 de C5 e 3 de C6);

- Grupo 5 (G5) é formado por 15 cepas, sendo 1 de C4, 11 de C5 e 3 de C6);

- Grupo 6 (G6), formado por 32 cepas, sendo o segundo maior grupo (3 cepas de C3, 8 de $\mathrm{C} 4,13$ de $\mathrm{C} 5,2$ de $\mathrm{C} 6$ e 6 cepas provenientes da coleta 7 (C7)).

Ainda, 16 cepas não ficaram agrupadas (4 cepas de C7, 2 cepas de C6, 2 de C5, 1 de C4 e 7 cepas provenientes de C3). Os valores de suporte por bootstrap dos ramos variaram de 92 a 100\% (Figura A.2 - APÊNDICE A).

\subsection{Avaliação da metodologia analítica para as fumonisinas $B_{1}$ e $B_{2}$}

As curvas de calibração, utilizadas para a quantificação das $\mathrm{FB}_{1}$ e $\mathrm{FB}_{2}$, tanto nas análises das amostras de milho quanto para o potencial toxigênico das cepas de $F$. verticillioides, foram lineares nas faixas de concentrações de 0,3125 a $10 \mu \mathrm{g} / \mathrm{mL}$. O coeficiente de correlação para as curvas de calibração 1 foi de 0,9997 para $\mathrm{FB}_{1}$ e $\mathrm{FB}_{2}$ e para as curvas de calibração 2, os coeficientes foram de 0,9919 para $\mathrm{FB}_{1}$ e 0,9958 para $\mathrm{FB}_{2}$.

Os testes para determinação de fumonisinas em milho foram realizados em amostras livre de fumonisinas (níveis não detectáveis nas condições do nosso experimento) e artificialmente contaminadas com $\mathrm{FB}_{1}$ e $\mathrm{FB}_{2}$, em seis diferentes concentrações $(0,015$ a $0,3 \mu \mathrm{g} / \mathrm{g}$ ) e em triplicata. A recuperação média foi de $94,1 \%$ para $\mathrm{FB}_{1}$ e 95,1\% para $\mathrm{FB}_{2}$.

$\mathrm{O}$ limite de quantificação para $\mathrm{FB}_{1}$ e $\mathrm{FB}_{2}$, utilizando colunas de imunoafinidade, foi de $0,015 \mu \mathrm{g} / \mathrm{g}$. O limite de detecção foi de $0,0097 \mu \mathrm{g} / \mathrm{g}$ para ambas fumonisinas, sendo determinado como a concentração onde a área do pico se encontrava três vezes acima da linha de base padrão. .Com o emprego de colunas SAX, o limite de quantificação para ambas fumonisinas foi de $0,05 \mu \mathrm{g} / \mathrm{g}$.

\subsection{Determinação de fumonisinas nos grãos de milho}

Das 364 amostras analisadas, 100\% apresentaram contaminação por $\mathrm{FB}_{1}$ e apenas $12,9 \%$ por $\mathrm{FB}_{2}$. Na coleta realizada no estádio $\mathrm{R} 1$ (C1), a presença de $\mathrm{FB}_{2}$ foi registrada apenas nas amostras A6 e A7, com níveis de 0,02 e 0,03 $\mu \mathrm{g} / \mathrm{g}$, respectivamente. Já os níveis 
de $\mathrm{FB}_{1}$ variaram 0,03 a $0,82 \mu \mathrm{g} / \mathrm{g}$, com média de $0,15 \mu \mathrm{g} / \mathrm{g}$ (Tabela 4). Na coleta R2 (C2), estádio de grão leitoso, os níveis de $\mathrm{FB}_{1}$ variaram de 0,04 a $0,93 \mu \mathrm{g} / \mathrm{g}$, com média de 0,19 $\mu \mathrm{g} / \mathrm{g}$. Nesta coleta, $\mathrm{FB}_{2}$ não foi detectada nas amostras (Tabela 4). Na coleta R3 (C3), estádio de grão pastoso, os níveis de $\mathrm{FB}_{1}$ variaram de 0,08 a $1,01 \mu \mathrm{g} / \mathrm{g}$, com média de $0,41 \mu \mathrm{g} / \mathrm{g}$. FB2 foi detectada em apenas 6 amostras (A19, A23, A25, A42 e A50) com níveis entre 0,02 $\mu \mathrm{g} / \mathrm{g}$ e $0,03 \mu \mathrm{g} / \mathrm{g})$ (tabela 4$)$.

No estádio de grão farináceo R4 (C4) os níveis de $\mathrm{FB}_{1}$ estavam entre 0,04 e 0,77 $\mu \mathrm{g} / \mathrm{g}$, com média de $0,12 \mu \mathrm{g} / \mathrm{g}$, e $\mathrm{FB}_{2}$ não foi detectada em nenhuma amostra (Tabela 5). No estádio de grão farináceo-duro R5 (C5) os níveis de $\mathrm{FB}_{1}$ estavam entre 0,02 e $0,91 \mu \mathrm{g} / \mathrm{g}$, com média de $0,11 \mu \mathrm{g} / \mathrm{g}$, e $\mathrm{FB}_{2}$ foi detectada nas amostras A20 e A25 com 0,02 e 0,36 $\mu \mathrm{g} / \mathrm{g}$, respectivamente (Tabela 5). Já no estádio de maturidade fisiológica R6 (C6) os níveis de FB encontravam-se entre 0,02 e 3,42 $\mu \mathrm{g} / \mathrm{g}$, com média de $0,32 \mu \mathrm{g} / \mathrm{g}$, enquanto $\mathrm{FB}_{2}$ foi detectada em 10 amostras com níveis de 0,03 a 2,9 $\mu \mathrm{g} / \mathrm{g}$, com média de $0,71 \mu \mathrm{g} / \mathrm{g}$ entre elas (Tabela 5).

Por fim, na coleta final (C7), os níveis de $\mathrm{FB}_{1}$ variaram 0,02 a 5,12 $\mu \mathrm{g} / \mathrm{g}$, com média de $1,26 \mu \mathrm{g} / \mathrm{g}$. Já $\mathrm{FB}_{2}$ foi detectada em 27 amostras (51,92\%) com níveis de 0,02 a 1,74 $\mu \mathrm{g} / \mathrm{g}$ e média de 0,77 $\mu \mathrm{g} / \mathrm{g}$, entre elas (Tabela 6). As figuras 18 e 19 representam as médias de $\mathrm{FB}_{1} \mathrm{e}$ $\mathrm{FB}_{2}$, respectivamente, encontradas nas sete coletas. 
Tabela 4. Concentração das fumonisinas $\mathrm{B}_{1}$ e $\mathrm{B}_{2}$ em 52 amostras de grãos de milho, provenientes do município de Cruzália, estado de São Paulo, nas fases de florescimento, grão leitoso e grão pastoso.

\begin{tabular}{|c|c|c|c|c|c|c|}
\hline \multirow[t]{2}{*}{ Amostra } & \multicolumn{2}{|c|}{ Florescimento } & \multicolumn{2}{|c|}{ Grão leitoso } & \multicolumn{2}{|c|}{ Grão pastoso } \\
\hline & $\mathrm{FB} 1(\mu \mathrm{g} / \mathrm{g})$ & $\mathrm{FB} 2(\mu \mathrm{g} / \mathrm{g})$ & $\mathrm{FB} 1(\mu \mathrm{g} / \mathrm{g})$ & FB2 $(\mu g / g)$ & $\mathrm{FB} 1(\mu \mathrm{g} / \mathrm{g})$ & $\mathrm{FB} 2(\mu \mathrm{g} / \mathrm{g})$ \\
\hline A1 & 0,16 & ND* & 0,12 & ND & 0,38 & ND \\
\hline A2 & 0,05 & ND & 0,93 & ND & 0,47 & ND \\
\hline A3 & 0,06 & ND & 0,16 & ND & 0,38 & ND \\
\hline A4 & 0,13 & ND & 0,12 & ND & 0,52 & ND \\
\hline A5 & 0,06 & ND & 0,12 & ND & 0,55 & ND \\
\hline A6 & 0,15 & 0,02 & 0,11 & ND & 0,31 & ND \\
\hline A7 & 0,29 & 0,03 & 0,08 & ND & 0,33 & ND \\
\hline A8 & 0,05 & ND & 0,14 & ND & 0,36 & ND \\
\hline A9 & 0,03 & ND & 0,16 & ND & 0,52 & ND \\
\hline A10 & 0,09 & ND & 0,07 & ND & 0,71 & ND \\
\hline A11 & 0,04 & ND & 0,12 & ND & 0,51 & ND \\
\hline A12 & 0,03 & ND & 0,04 & ND & 0,5 & ND \\
\hline A13 & 0,04 & ND & 0,05 & ND & 0,68 & ND \\
\hline A14 & 0,05 & ND & 0,12 & ND & 0,73 & ND \\
\hline A15 & 0,03 & ND & 0,18 & ND & 0,36 & ND \\
\hline A16 & 0,04 & ND & 0,22 & ND & 0,24 & ND \\
\hline A17 & 0,04 & ND & 0,14 & ND & 0,17 & ND \\
\hline A18 & 0,04 & ND & 0,07 & ND & 0,08 & ND \\
\hline A19 & 0,06 & ND & 0,12 & ND & 0,42 & 0,02 \\
\hline A20 & 0,08 & ND & 0,05 & ND & 0,49 & ND \\
\hline A21 & 0,11 & ND & 0,20 & ND & 0,49 & ND \\
\hline A22 & 0,82 & ND & 0,14 & ND & 0,59 & ND \\
\hline A23 & 0,04 & ND & 0,11 & ND & 0,31 & 0,02 \\
\hline A24 & 0,06 & ND & 0,08 & ND & 0,18 & ND \\
\hline A25 & 0,1 & ND & 0,10 & ND & 0,42 & 0,02 \\
\hline A26 & 0,06 & ND & 0,12 & ND & 0,22 & ND \\
\hline A27 & 0,06 & ND & 0,11 & ND & 0,51 & ND \\
\hline A28 & 0,12 & ND & 0,04 & ND & 0,15 & ND \\
\hline A29 & 0,05 & ND & 0,17 & ND & 0,17 & ND \\
\hline A30 & 0,12 & ND & 0,11 & ND & 0,28 & ND \\
\hline A31 & 0,1 & ND & 0,14 & ND & 0,08 & ND \\
\hline A32 & 0,17 & ND & 0,10 & ND & 0,59 & ND \\
\hline A33 & 0,1 & ND & 0,07 & ND & 0,27 & ND \\
\hline A34 & 0,17 & ND & 0,09 & ND & 0,16 & ND \\
\hline A35 & 0,04 & ND & 0,14 & ND & 0,2 & ND \\
\hline A36 & 0,06 & ND & 0,35 & ND & 0,22 & ND \\
\hline A37 & 0,14 & ND & 0,22 & ND & 0,21 & ND \\
\hline A38 & 0,21 & ND & 0,11 & ND & 0,23 & ND \\
\hline A39 & 0,15 & ND & 0,09 & ND & 0,26 & ND \\
\hline A40 & 0,19 & ND & 0,21 & ND & 0,37 & ND \\
\hline A41 & 0,17 & ND & 0,10 & ND & 0,08 & ND \\
\hline A42 & 0,13 & ND & 0,16 & ND & 0,16 & 0,02 \\
\hline A43 & 0,33 & ND & 0,21 & ND & 0,26 & ND \\
\hline A44 & 0,3 & ND & 0,26 & ND & 0,21 & 0,03 \\
\hline A45 & 0,54 & ND & 0,26 & ND & 0,53 & ND \\
\hline A46 & 0,22 & ND & 0,31 & ND & 0,4 & ND \\
\hline A47 & 0,35 & ND & 0,22 & ND & 0,43 & ND \\
\hline A48 & 0,21 & ND & 0,12 & ND & 0,85 & ND \\
\hline A49 & 0,13 & ND & 0,22 & ND & 0,25 & ND \\
\hline A50 & 0,15 & ND & 0,10 & ND & 1,01 & 0,02 \\
\hline A51 & 0,09 & ND & 0,13 & ND & 0,63 & ND \\
\hline A52 & 0,18 & ND & 0,90 & ND & 0,47 & ND \\
\hline Média & 0,15 & 0,025 & 0,19 & - & 0,41 & 0,022 \\
\hline $\begin{array}{l}\text { Desvio } \\
\text { Padrão }\end{array}$ & 0,137 & 0,005 & 0,163 & - & 0,2 & 0,004 \\
\hline
\end{tabular}

*ND = não detectado; limite de quantificação para $\mathrm{FB}_{1}$ e $\mathrm{FB}_{2}=0,015 \mu \mathrm{g} / \mathrm{g}$; a média e desvio padrão para $\mathrm{FB}_{2}$ correspondem apenas àquelas amostras nas quais a toxina foi detectada. 
Tabela 5. Concentração das fumonisinas $B_{1}$ e $B_{2}$ em 52 amostras de grãos de milho, provenientes do município de Cruzália, estado de São Paulo, nas fases de grão farináceo, grão farináceo-duro e grão em maturidade fisiológica.

\begin{tabular}{|c|c|c|c|c|c|c|}
\hline \multirow[t]{2}{*}{$\overline{\text { Amostra }}$} & \multicolumn{2}{|c|}{ Grão farináceo } & \multicolumn{2}{|c|}{ Grão farináceo-duro } & \multicolumn{2}{|c|}{ Maturidade fisiológica } \\
\hline & $\mathrm{FB} 1(\mu \mathrm{g} / \mathrm{g})$ & $\mathrm{FB} 2(\mu \mathrm{g} / \mathrm{g})$ & $\mathrm{FB} 1(\mu \mathrm{g} / \mathrm{g})$ & $\mathrm{FB} 2(\mu \mathrm{g} / \mathrm{g})$ & $\mathrm{FB} 1(\mu \mathrm{g} / \mathrm{g})$ & FB2 $(\mu \mathrm{g} / \mathrm{g})$ \\
\hline A1 & 0,41 & ND* & 0,07 & ND & 0,17 & ND \\
\hline A2 & 0,04 & ND & 0,04 & ND & 0,09 & ND \\
\hline A3 & 0,1 & ND & 0,05 & ND & 0,08 & ND \\
\hline A4 & 0,13 & ND & 0,07 & ND & 0,06 & ND \\
\hline A5 & 0,1 & ND & 0,06 & ND & 0,04 & ND \\
\hline A6 & 0,19 & ND & 0,06 & ND & 0,58 & 0,08 \\
\hline A7 & 0,17 & ND & 0,06 & ND & 3,42 & 2,9 \\
\hline A8 & 0,19 & ND & 0,09 & ND & 1,22 & 0,6 \\
\hline A9 & 0,13 & ND & 0,08 & ND & 0,22 & 0,04 \\
\hline A10 & 0,11 & ND & 0,08 & ND & 0,08 & ND \\
\hline A11 & 0,13 & ND & 0,16 & ND & 2,9 & 0,95 \\
\hline A12 & 0,14 & ND & 0,03 & ND & 0,13 & ND \\
\hline A13 & 0,77 & ND & 0,08 & ND & 0,12 & ND \\
\hline A14 & 0,09 & ND & 0,08 & ND & 0,09 & ND \\
\hline A15 & 0,06 & ND & 0,02 & ND & 0,14 & ND \\
\hline A16 & 0,05 & ND & 0,1 & ND & 0,27 & 0,06 \\
\hline A17 & 0,07 & ND & 0,14 & ND & 0,09 & ND \\
\hline A18 & 0,05 & ND & 0,03 & ND & 0,05 & ND \\
\hline A19 & 0,12 & ND & 0,03 & ND & 0,05 & ND \\
\hline A20 & 0,18 & ND & 0,07 & 0,02 & 0,05 & ND \\
\hline A21 & 0,12 & ND & 0,08 & ND & 0,09 & ND \\
\hline A22 & 0,07 & ND & 0,08 & ND & 0,05 & ND \\
\hline A23 & 0,13 & ND & 0,08 & ND & 0,08 & ND \\
\hline A24 & 0,12 & ND & 0,07 & ND & 0,08 & ND \\
\hline A25 & 0,05 & ND & 0,62 & 0,36 & 0,06 & ND \\
\hline A26 & 0,12 & ND & 0,05 & ND & 0,07 & ND \\
\hline A27 & 0,07 & ND & 0,91 & ND & 0,06 & ND \\
\hline A28 & 0,1 & ND & 0,14 & ND & 0,06 & ND \\
\hline A29 & 0,06 & ND & 0,1 & ND & 0,03 & ND \\
\hline A30 & 0,04 & ND & 0,21 & ND & 0,07 & ND \\
\hline A31 & 0,04 & ND & 0,08 & ND & 0,07 & ND \\
\hline A32 & 0,04 & ND & 0,05 & ND & 0,06 & ND \\
\hline A33 & 0,08 & ND & 0,1 & ND & 0,04 & ND \\
\hline A34 & 0,05 & ND & 0,09 & ND & 0,04 & ND \\
\hline A35 & 0,1 & ND & 0,08 & ND & 0,05 & ND \\
\hline A36 & 0,09 & ND & 0,04 & ND & 0,02 & ND \\
\hline A37 & 0,14 & ND & 0,11 & ND & 0,09 & ND \\
\hline A38 & 0,08 & ND & 0,09 & ND & 0,18 & ND \\
\hline A39 & 0,09 & ND & 0,05 & ND & 0,43 & 0,13 \\
\hline A40 & 0,11 & ND & 0,08 & ND & 0,04 & ND \\
\hline A41 & 0,11 & ND & 0,06 & ND & 0,14 & ND \\
\hline A42 & 0,07 & ND & 0,13 & ND & 3,32 & 2,21 \\
\hline A43 & 0,06 & ND & 0,11 & ND & 0,05 & ND \\
\hline A44 & 0,07 & ND & 0,08 & ND & 0,37 & 0,07 \\
\hline A45 & 0,14 & ND & 0,08 & ND & 0,07 & ND \\
\hline A46 & 0,07 & ND & 0,11 & ND & 0,05 & ND \\
\hline A47 & 0,13 & ND & 0,05 & ND & 0,12 & ND \\
\hline A48 & 0,05 & ND & 0,07 & ND & 0,13 & ND \\
\hline A49 & 0,04 & ND & 0,08 & ND & 0,11 & ND \\
\hline A50 & 0,09 & ND & 0,1 & ND & 0,12 & ND \\
\hline A51 & 0,1 & ND & 0,07 & ND & 0,06 & ND \\
\hline A52 & 0,06 & ND & 0,06 & ND & 0,51 & 0,03 \\
\hline Média & 0,12 & - & 0,11 & 0,19 & 0,32 & 0,71 \\
\hline $\begin{array}{l}\text { Desvio } \\
\text { padrão }\end{array}$ & 0,109 & - & 0,139 & 0,24 & 0,743 & 0,979 \\
\hline
\end{tabular}


Tabela 6. Concentração das fumonisinas $B_{1}$ e $B_{2}$ em 52 amostras de grãos de milho, provenientes do município de Cruzália, estado de São Paulo, na fase de colheita final.

\begin{tabular}{|c|c|c|c|c|c|}
\hline Amostra & FB1 $(\mu \mathrm{g} / \mathrm{g})$ & FB2 $(\mu \mathrm{g} / \mathrm{g})$ & Amostra & FB1 $(\mu \mathrm{g} / \mathrm{g})$ & FB2 $(\mu \mathrm{g} / \mathrm{g})$ \\
\hline A1 & 0,07 & ND & A27 & 1,19 & 0,55 \\
\hline A2 & 0,24 & 0,02 & A28 & 4,10 & 1,7 \\
\hline A3 & 0,38 & ND & A29 & 4,13 & 2,09 \\
\hline A4 & 0,68 & ND & A30 & 0,10 & 0,08 \\
\hline A5 & 0,14 & 0,02 & A31 & 4,35 & 1,69 \\
\hline A6 & 0,48 & ND & A32 & 2,66 & 0,48 \\
\hline A7 & 0,39 & ND & A33 & 3,97 & 1,74 \\
\hline A8 & 0,55 & ND & A34 & 0,06 & ND \\
\hline A9 & 2,76 & 1,23 & A35 & 0,09 & ND \\
\hline A10 & 0,07 & ND & A36 & 0,22 & ND \\
\hline A11 & 0,06 & ND & A37 & 0,11 & ND \\
\hline A12 & 0,03 & ND & A38 & 0,53 & 0,09 \\
\hline A13 & 0,40 & 0,09 & A39 & 0,02 & ND \\
\hline A14 & 2,52 & 0,77 & A40 & 0,13 & ND \\
\hline A15 & 2,14 & 0,86 & A41 & 1,84 & 0,66 \\
\hline A16 & 0,02 & ND & A42 & 0,13 & ND \\
\hline A17 & 0,97 & 0,33 & A43 & 3,84 & 1,31 \\
\hline A18 & 1,99 & 1,56 & A44 & 1,81 & 0,45 \\
\hline A19 & 0,05 & ND & A45 & 0,16 & ND \\
\hline A20 & 0,12 & ND & A46 & 0,14 & ND \\
\hline A21 & 2,36 & 0,93 & A47 & 0,37 & 0,09 \\
\hline A22 & 3,35 & 0,34 & A48 & 0,22 & ND \\
\hline A23 & 5,12 & 0,43 & A49 & 2,39 & 0,69 \\
\hline A24 & 2,76 & 1,22 & A50 & 0,18 & ND \\
\hline A25 & 0,05 & ND & A51 & 3,13 & 0,90 \\
\hline A26 & 0,13 & ND & A52 & 1,72 & 0,58 \\
\hline Média & 1,26 & 0,77 & Desvio padrão & 1,461 & 0,595 \\
\hline
\end{tabular}

$\mathrm{ND}=$ não detectado; limite de quantificação para $\mathrm{FB}_{1}$ e $\mathrm{FB}_{2}=0,015 \mu \mathrm{g} / \mathrm{g}$; a média e desvio padrão para $\mathrm{FB}_{2}$ correspondem apenas àquelas amostras nas quais a toxina foi detectada.

Figura 18. Médias de fumonisina $B_{1}(\mu \mathrm{g} / \mathrm{g})$ detectadas nas amostras de milho, provenientes do município de Cruzália, estado de São Paulo, nas sete coletas (52 amostras por coleta).

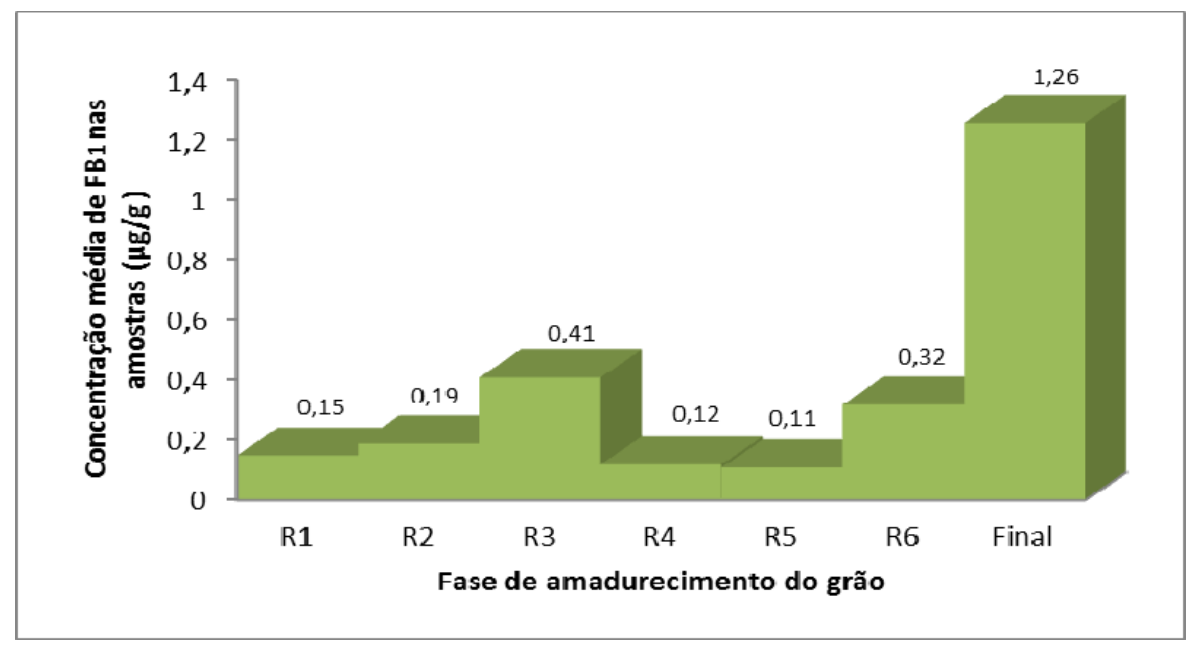


Figura 19. Médias de fumonisina $B_{2}(\mu \mathrm{g} / \mathrm{g})$ detectadas nas amostras de milho, provenientes do município de Cruzália, estado de São Paulo, nas sete coletas, média entre àquelas amostras cuja essa toxina foi detectada.

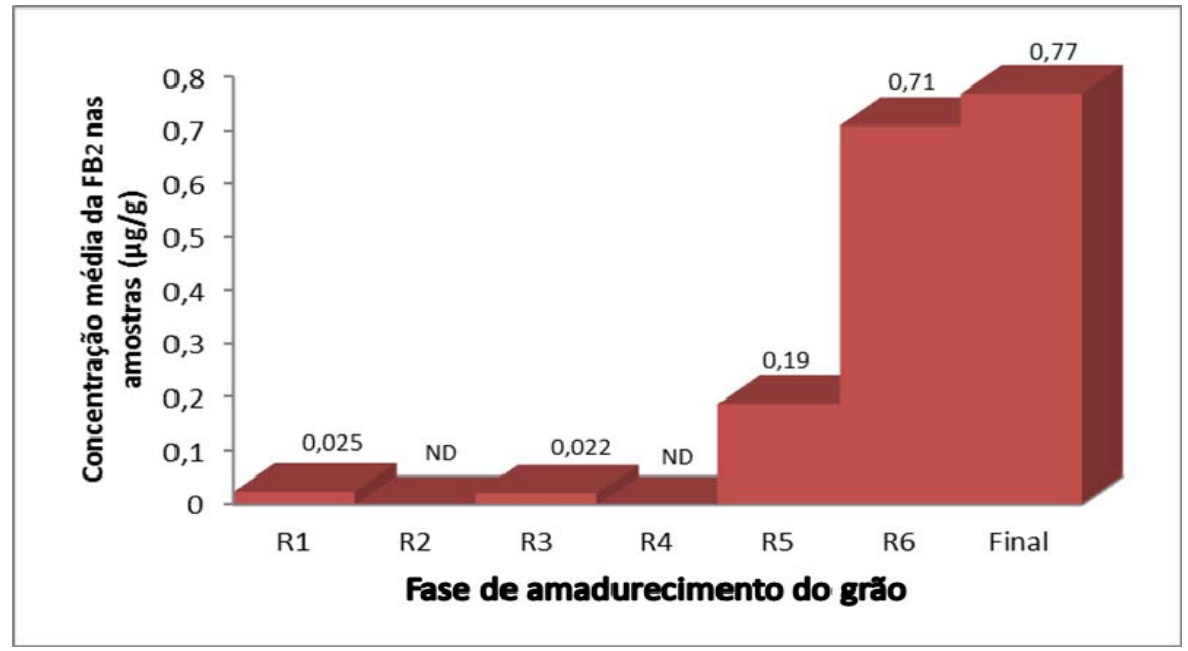

\subsection{Avaliação do Potencial Toxigênico das cepas de $F$. verticillioides isoladas}

A Análise do potencial toxigênico de 217 cepas de Fusarium verticilliodes isoladas das amostras de grãos de milho, revelou a produção de fumonisinas $\mathrm{B}_{1}$ e $\mathrm{B}_{2}$ por $100 \%$ das cepas. Os níveis variaram de 0,35 a $8975,63 \mu \mathrm{g} / \mathrm{g}$ para $\mathrm{FB}_{1}$ e de 0,05 a $725,71 \mu \mathrm{g} / \mathrm{g}$ para $\mathrm{FB}_{2}$. As médias entre todas as cepas foram de $208,79 \mu \mathrm{g} / \mathrm{g}$ para $\mathrm{FB}_{1}$ e de $14,89 \mu \mathrm{g} / \mathrm{g}$ para $\mathrm{FB}_{2}$.

$\mathrm{Na}$ fase de florescimento, foram isoladas 6 cepas produtoras de $\mathrm{FB}_{1}$ e $\mathrm{FB}_{2}$ com níveis variando de 2,22 a $9,78 \mu \mathrm{g} / \mathrm{g}\left(\mathrm{FB}_{1}\right)$ e de 0,06 a $0,75 \mu \mathrm{g} / \mathrm{g}\left(\mathrm{FB}_{2}\right)$ (Tabela 7$)$. Na fase de grão leitoso, foi isolada apenas uma cepa produtora de $\mathrm{FB}_{1}(1,63 \mu \mathrm{g} / \mathrm{g})$ e $\mathrm{FB}_{2}(0,07 \mu \mathrm{g} / \mathrm{g})$ (Tabela 7).

Tabela 7. Produção de fumonisinas pelas cepas de F. verticillioides isoladas de grãos de milho das fases de florescimento e grão leitoso.

\begin{tabular}{|c|c|c|c|c|c|}
\hline $\begin{array}{c}\text { Cepa } \\
\text { (Florescimento) }\end{array}$ & $\begin{array}{c}\mathrm{FB} 1 \\
(\mu \mathrm{g} / \mathrm{g})\end{array}$ & $\begin{array}{c}\mathrm{FB} 2 \\
(\mu \mathrm{g} / \mathrm{g})\end{array}$ & $\begin{array}{c}\text { Cepa } \\
\text { (grão leitoso) }\end{array}$ & $\begin{array}{c}\mathrm{FB} 1 \\
(\mu \mathrm{g} / \mathrm{g})\end{array}$ & $\begin{array}{c}\mathrm{FB} 2 \\
(\mu \mathrm{g} / \mathrm{g})\end{array}$ \\
\hline $\mathbf{1}$ & 2,22 & 0,65 & $\mathbf{7}$ & 1,63 & 0,07 \\
\hline $\mathbf{2}$ & 9,78 & 0,15 & - & - & - \\
\hline $\mathbf{3}$ & 2,42 & 0,12 & - & - & - \\
\hline $\mathbf{4}$ & 4,87 & 0,28 & - & - & - \\
\hline $\mathbf{5}$ & 2,8 & 0,06 & - & - & - \\
\hline $\mathbf{6}$ & 7,05 & 0,75 & - & - & - \\
\hline Média & 4,86 & 0,34 & - & - & - \\
\hline Desvio Padrão & 2,774 & 0,268 & - & - & - \\
\hline
\end{tabular}


Já na fase de grão pastoso, as 31 cepas analisadas produziram níveis que variaram de 1,59 a 1589,63 $\mu \mathrm{g} / \mathrm{g}\left(\mathrm{FB}_{1}\right)$ e de 0,1 a 17,63 $\mu \mathrm{g} / \mathrm{g}\left(\mathrm{FB}_{2}\right)$ (Tabela 8). Na fase de grão farináceo as 41 cepas analisadas produziram concentrações de fumonisinas que variaram de 1,11 a $236,65 \mu \mathrm{g} / \mathrm{g}\left(\mathrm{FB}_{1}\right)$ e de 0,07 a 10,87 $\mu \mathrm{g} / \mathrm{g}\left(\mathrm{FB}_{2}\right)$ (Tabela 8). Na fase de grão farináceo-duro as 43 cepas produziram níveis variando de 1,45 a $8975,63 \mu \mathrm{g} / \mathrm{g}\left(\mathrm{FB}_{1}\right)$ e de 0,09 a $156,73 \mu \mathrm{g} / \mathrm{g}$ $\left(\mathrm{FB}_{2}\right)$ (Tabela 8).

$\mathrm{Na}$ fase de maturidade fisiológica foram analisadas 49 cepas. Os níveis de fumonisinas variaram de 0,35 a 7654,32 $\mu \mathrm{g} / \mathrm{g}\left(\mathrm{FB}_{1}\right)$ e de 0,06 a 725,71 ( $\left.\mathrm{FB}_{2}\right)$ (Tabela 9). Por último, na coleta final, foram analisadas 46 cepas cujos níveis de produção variaram de 1,1 a 2745,41 $\mu \mathrm{g} / \mathrm{g}\left(\mathrm{FB}_{1}\right)$ e de 0,11 a $153,16 \mu \mathrm{g} / \mathrm{g}\left(\mathrm{FB}_{2}\right)$ (Tabela 9$)$.

$\mathrm{O}$ maior nível de produção de $\mathrm{FB}_{1}$ foi encontrado em uma cepa da fase de grão farináceo-duro $(8975,63 \mu \mathrm{g} / \mathrm{g})$, porém, a maior média para essa toxina foi entre as cepas da fase seguinte, maturidade fisiológica $(428,94 \mu \mathrm{g} / \mathrm{g})$, fase em que também foi encontrada a cepa com menor capacidade de produção dessa toxina $(0,35 \mu \mathrm{g} / \mathrm{g})$. Em relação à $\mathrm{FB}_{2}$, a cepa com maior produção foi isolada da maturidade fisiológica $(725,71 \mu \mathrm{g} / \mathrm{g})$. Já a menor produção de $\mathrm{FB}_{2}$ foi registrada em uma cepa pertencente à fase de grão leitoso $(0,07 \mu \mathrm{g} / \mathrm{g})$. 
Tabela 8. Produção de fumonisinas pelas cepas de $F$. verticillioides isoladas de grãos de milho das fases de grão pastoso, grão farináceo e grão farináceo duro.

\begin{tabular}{|c|c|c|c|c|c|c|c|c|}
\hline $\begin{array}{c}\text { Cepa } \\
\text { (grão pastoso) }\end{array}$ & $\begin{array}{c}\mathrm{FB} 1 \\
(\mu \mathrm{g} / \mathrm{g})\end{array}$ & $\begin{array}{c}\mathrm{FB} 2 \\
(\mu \mathrm{g} /)\end{array}$ & $\begin{array}{c}\text { Cepa } \\
\text { (grão farináceo) }\end{array}$ & $\begin{array}{c}\mathrm{FB} 1 \\
(\mu \mathrm{g} / \mathrm{g})\end{array}$ & $\begin{array}{c}\mathrm{FB} 2 \\
(\mu \mathrm{g} / \mathrm{g})\end{array}$ & $\begin{array}{c}\text { Cepa } \\
\text { (farináceo-duro }\end{array}$ & $\mathrm{FB} 1(\mu \mathrm{g} / \mathrm{g})$ & $\begin{array}{c}\mathrm{FB} 2 \\
(\mu \mathrm{g} / \mathrm{g})\end{array}$ \\
\hline 8 & 1,79 & 0,11 & 39 & 17,27 & 0,75 & 80 & 28,73 & 3,45 \\
\hline 9 & 655,78 & 1,2 & 40 & 20,86 & 2,36 & 81 & 1,8 & 0,16 \\
\hline 10 & 3,35 & 0,7 & 41 & 28,44 & 2,34 & 82 & 505,69 & 5,26 \\
\hline 11 & 1,93 & 0,21 & 42 & 2,3 & 0,23 & 83 & 12,85 & 3,63 \\
\hline 12 & 4,15 & 0,31 & 43 & 9,34 & 0,68 & 84 & 22,13 & 1,5 \\
\hline 13 & 3,42 & 0,61 & 44 & 5,36 & 0,53 & 85 & 145,67 & 2,87 \\
\hline 14 & 1,59 & 0,4 & 45 & 1,52 & 0,43 & 86 & 27,06 & 7,48 \\
\hline 15 & 7,76 & 0,17 & 46 & 1,3 & 0,28 & 87 & 1,45 & 0,09 \\
\hline 16 & 43,74 & 0,57 & 47 & 2,96 & 0,33 & 88 & 12,34 & 1,71 \\
\hline 17 & 40,16 & 3,29 & 48 & 2,28 & 0,14 & 89 & 1,69 & 0,43 \\
\hline 18 & 2,03 & 0,22 & 49 & 1,57 & 0,38 & 90 & 8975,64 & 156,73 \\
\hline 19 & 20,95 & 0,42 & 50 & 5,41 & 0,46 & 91 & 34,76 & 0,79 \\
\hline 20 & 2,05 & 0,32 & 51 & 2,2 & 0,18 & 92 & 17,63 & 0,98 \\
\hline 21 & 4,44 & 0,35 & 52 & 2,86 & 0,41 & 93 & 25,54 & 1,25 \\
\hline 22 & 6,6 & 0,23 & 53 & 2,31 & 0,73 & 94 & 73,97 & 1,25 \\
\hline 23 & 159,19 & 3,65 & 54 & 46,47 & 1,71 & 95 & 39,43 & 1,72 \\
\hline 24 & 24,87 & 0,68 & 55 & 2,7 & 0,17 & 96 & 6,9 & 0,21 \\
\hline 25 & 4,97 & 0,1 & 56 & 68,25 & 0,35 & 97 & 2,32 & 0,17 \\
\hline 26 & 79,23 & 5,9 & 57 & 2,46 & 0,12 & 98 & 9,58 & 0,236 \\
\hline 27 & 60,15 & 1,44 & 58 & 2,45 & 0,13 & 99 & 10,46 & 0,81 \\
\hline 28 & 6,66 & 0,28 & 59 & 1,67 & 0,1 & 100 & 4,54 & 0,36 \\
\hline 29 & 7,36 & 0,14 & 60 & 3,66 & 0,1 & 101 & 6,08 & 0,34 \\
\hline 30 & 6,08 & 0,33 & 61 & 2,0 & 0,09 & 102 & 695,13 & 144,02 \\
\hline 31 & 8,22 & 0,33 & 62 & 3,05 & 0,11 & 103 & 61,72 & 2,79 \\
\hline 32 & 24,87 & 0,25 & 63 & 2,39 & 0,13 & 104 & 584,7 & 8,01 \\
\hline 33 & 15,84 & 0,71 & 64 & 48,83 & 0,36 & 105 & 9,0 & 0,71 \\
\hline 34 & 9,67 & 0,35 & 65 & 40,19 & 0,56 & 106 & 8,9 & 0,73 \\
\hline 35 & 22,31 & 0,27 & 66 & 13,31 & 0,35 & 107 & 7,15 & 0,38 \\
\hline 36 & 20,65 & 0,1 & 67 & 15,92 & 0,41 & 108 & 389,59 & 105,46 \\
\hline 37 & 34,81 & 0,92 & 68 & 34,43 & 0,52 & 109 & 16,14 & 1,09 \\
\hline 38 & 1589,63 & 17,63 & 69 & 2,3 & 0,21 & 110 & 221,48 & 3,38 \\
\hline- & - & - & 70 & 5,29 & 0,22 & 111 & 4,42 & 0,54 \\
\hline- & - & - & 71 & 1,61 & 0,07 & 112 & 2,94 & 0,2 \\
\hline- & - & - & 72 & 1,74 & 0,1 & 113 & 6,85 & 0,51 \\
\hline- & - & - & 73 & 5,44 & 0,31 & 114 & 3,39 & 0,13 \\
\hline- & - & - & 74 & 3,21 & 0,22 & 115 & 4,87 & 0,46 \\
\hline- & - & - & 75 & 4,95 & 0,32 & 116 & 185,16 & 21,41 \\
\hline- & - & - & 76 & 86,99 & 2,66 & 117 & 456,52 & 13,56 \\
\hline- & - & - & 77 & 16,07 & 1,02 & 118 & 5,21 & 0,72 \\
\hline- & - & - & 78 & 1,11 & 0,28 & 119 & 7,88 & 0,18 \\
\hline- & - & - & 79 & 236,65 & 10,87 & 120 & 82,32 & 0,67 \\
\hline- & - & - & - & - & - & 121 & 139,24 & 0,91 \\
\hline- & - & - & - & - & - & 122 & 195,73 & 16,35 \\
\hline Média & 92,72 & 1,36 & Média & 18,52 & 0,77 & Média & 303,6 & 11,95 \\
\hline Desvio Padrão & 296,963 & 3,214 & Desvio Padrão & 39,539 & 1,737 & Desvio Padrão & 1348,774 & 35,338 \\
\hline
\end{tabular}

Limite de quantificação para $\mathrm{FB}_{1}$ e $\mathrm{FB}_{2}=0,015 \mu \mathrm{g} / \mathrm{g}$ 
Tabela 9. Produção de fumonisinas pelas cepas de $F$. verticillioides isoladas de grãos de milho das fases de maturidade fisiológica e colheita final.

\begin{tabular}{|c|c|c|c|c|c|}
\hline $\begin{array}{c}\text { Cepa } \\
\text { (maturidade fisiológica) }\end{array}$ & $\mathrm{FB} 1(\mu \mathrm{g} / \mathrm{g})$ & FB2 $(\mu \mathrm{g} / \mathrm{g})$ & $\begin{array}{c}\text { Cepa } \\
\text { (colheita final) }\end{array}$ & $\mathrm{FB} 1(\mu \mathrm{g} / \mathrm{g})$ & $\mathrm{FB} 2(\mu \mathrm{g} / \mathrm{g})$ \\
\hline 123 & 9,88 & 0,87 & 172 & 5,71 & 0,40 \\
\hline 124 & 4,6 & 0,57 & 173 & 1,10 & 0,19 \\
\hline 125 & 3,4 & 0,31 & 174 & 38,55 & 0,88 \\
\hline 126 & 10,78 & 0,32 & 175 & 4,46 & 0,93 \\
\hline 127 & 370,57 & 26,61 & 176 & 1,17 & 0,19 \\
\hline 128 & 1946,53 & 20,7 & 177 & 8,52 & 0,24 \\
\hline 129 & 150,87 & 17,7 & 178 & 9,31 & 0,99 \\
\hline 130 & 2754,44 & 289,38 & 179 & 418,84 & 28,82 \\
\hline 131 & 23,41 & 0,51 & 180 & 6,74 & 0,41 \\
\hline 132 & 9,82 & 0,34 & 181 & 15,41 & 1,08 \\
\hline 133 & 135,46 & 9,08 & 182 & 7,81 & 0,87 \\
\hline 134 & 3,36 & 0,21 & 183 & 1,11 & 0,18 \\
\hline 135 & 14,68 & 0,4 & 184 & 42,78 & 9,40 \\
\hline 136 & 6,73 & 0,35 & 185 & 47,14 & 7,01 \\
\hline 137 & 37,48 & 0,7 & 186 & 1,10 & 0,33 \\
\hline 138 & 7,65 & 0,66 & 187 & 111,68 & 1,93 \\
\hline 139 & 2,06 & 0,15 & 188 & 4,72 & 0,11 \\
\hline 140 & 120,5 & 2,23 & 189 & 20,47 & 1,43 \\
\hline 141 & 5,43 & 0,12 & 190 & 282,10 & 32,43 \\
\hline 142 & 0,60 & 0,09 & 191 & 152,85 & 32,43 \\
\hline 143 & 0,99 & 0,10 & 192 & 1,83 & 0,24 \\
\hline 144 & 0,35 & 0,05 & 193 & 124,67 & 3,76 \\
\hline 145 & 0,77 & 0,07 & 194 & 26,59 & 3,48 \\
\hline 146 & 679,85 & 36,97 & 195 & 20,36 & 0,25 \\
\hline 147 & 1,25 & 0,17 & 196 & 128,01 & 0,47 \\
\hline 148 & 580,75 & 11,76 & 197 & 205,32 & 4,44 \\
\hline 149 & 6,67 & 0,48 & 198 & 211,50 & 6,38 \\
\hline 150 & 4,98 & 0,19 & 199 & 292,34 & 43,28 \\
\hline 151 & 13,57 & 1,44 & 200 & 5,02 & 0,76 \\
\hline 152 & 2285,57 & 408,36 & 201 & 834,56 & 92,08 \\
\hline 153 & 4,80 & 0,45 & 202 & 67,13 & 0,25 \\
\hline 154 & 7654,32 & 456,78 & 203 & 15,79 & 3,12 \\
\hline 155 & 0,66 & 0,06 & 204 & 360,06 & 7,41 \\
\hline 156 & 0,77 & 0,09 & 205 & 16,04 & 5,70 \\
\hline 157 & 0,67 & 0,06 & 206 & 10,31 & 1,09 \\
\hline 158 & 85,54 & 3,93 & 207 & 120,97 & 13,46 \\
\hline 159 & 0,73 & 0,06 & 208 & 25,04 & 1,83 \\
\hline 160 & 1,96 & 0,17 & 209 & 2745,41 & 153,16 \\
\hline 161 & 1,0 & 0,10 & 210 & 226,45 & 7,65 \\
\hline 162 & 0,65 & 0,07 & 211 & 759,22 & 82,96 \\
\hline 163 & 426,89 & 15,05 & 212 & 9,95 & 0,81 \\
\hline 164 & 1,01 & 0,11 & 213 & 8,34 & 0,54 \\
\hline 165 & 1,74 & 0,31 & 214 & 101,70 & 11,24 \\
\hline 166 & 5,40 & 0,70 & 215 & 42,36 & 1,34 \\
\hline 167 & 2,64 & 0,30 & 216 & 26,36 & 1,75 \\
\hline 168 & 522,64 & 12,31 & 217 & 3,61 & 0,33 \\
\hline 169 & 112,34 & 58,21 & - & - & - \\
\hline 170 & 2581,14 & 725,71 & - & - & - \\
\hline 171 & 419,95 & 92,47 & - & - & - \\
\hline Média & 428,94 & 44,85 & Média & 164,58 & 12,35 \\
\hline Desvio Padrão & 1232,903 & 135,72 & Desvio Padrão & 424,230 & 28,484 \\
\hline
\end{tabular}

Limite de quantificação para $\mathrm{FB}_{1}$ e $\mathrm{FB}_{2}=0,015 \mu \mathrm{g} / \mathrm{g}$ 
5.6 Análise da expressão dos genes $F U M$ em grãos de milho Bt por qPCR.

\subsubsection{Ensaio SPUD para deteccão de inibidores nas amostras de ácido nucléico}

Para a padronização do Ensaio SPUD, a análise do Ct de amplificação do amplicon SPUD-A foi feita considerando o threshold de 0,055804 para todas as amostras e com curva de dissociação $(\mathrm{Tm})$ de $78,4\left(+/-0,5^{\circ} \mathrm{C}\right)$ (Figura 20).

Figura 20. Curva de dissociação e perfil de amplificação do amplicon SPUD A obtidas na padronização do Ensaio SPUD.

a. Curva de dissociação

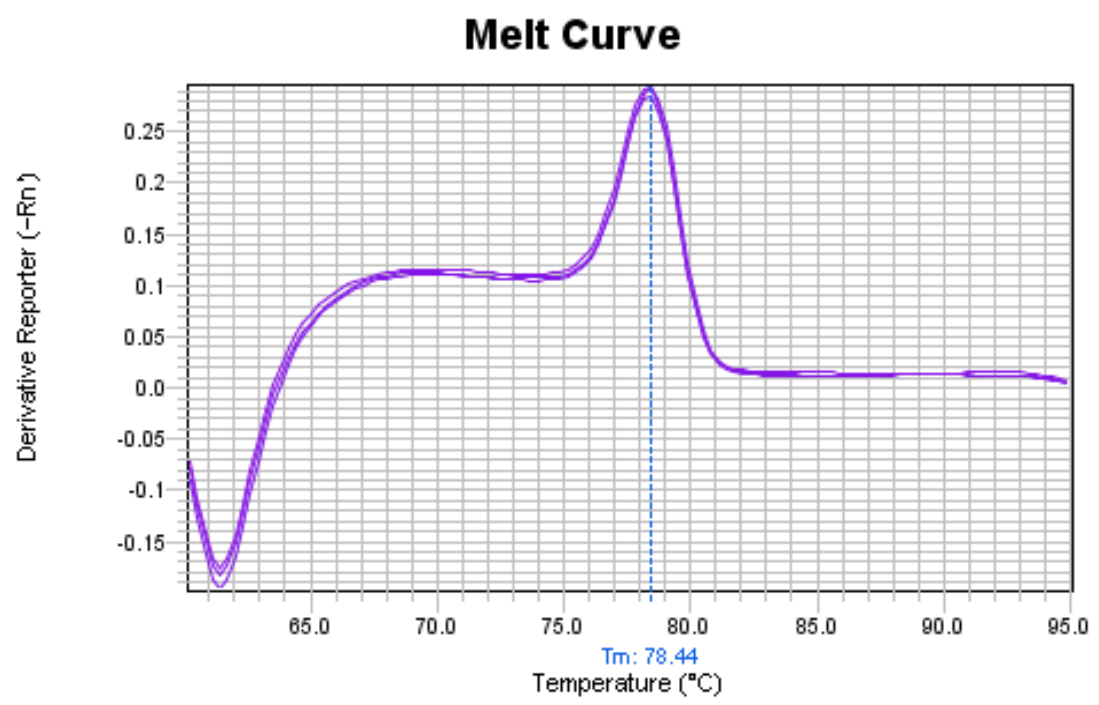

b. Perfil de amplificação

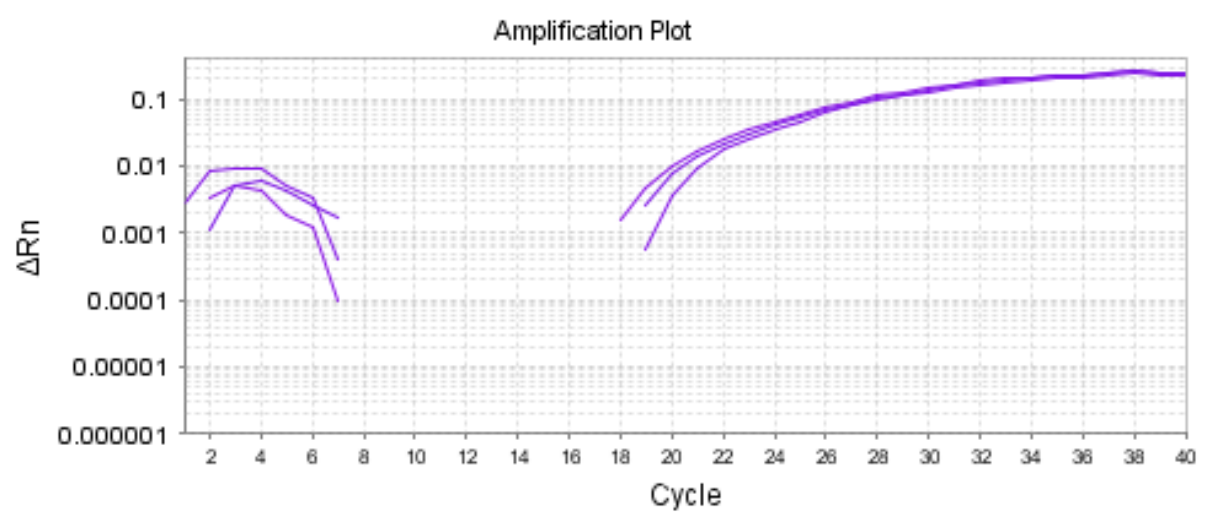

Aquelas amostras cujos Cts ficaram fora do limite de 23 a 25 e cujas curvas de dissociação também não ficou no limite estabelecido foram re-extraídas até demonstrarem-se apropriadas (Figura 21). 
Figura 21. Perfil de amplificação e curva de dissociação do amplicon SPUD A obtidas no Ensaio SPUD de três placas (A-B; C-D; E-F) contendo amostras de cDNA provenientes das 7 coletas realizadas. As placas A-B e C-D contém amostras sem inibidores e a placa E-F contém amostras com inibidores.
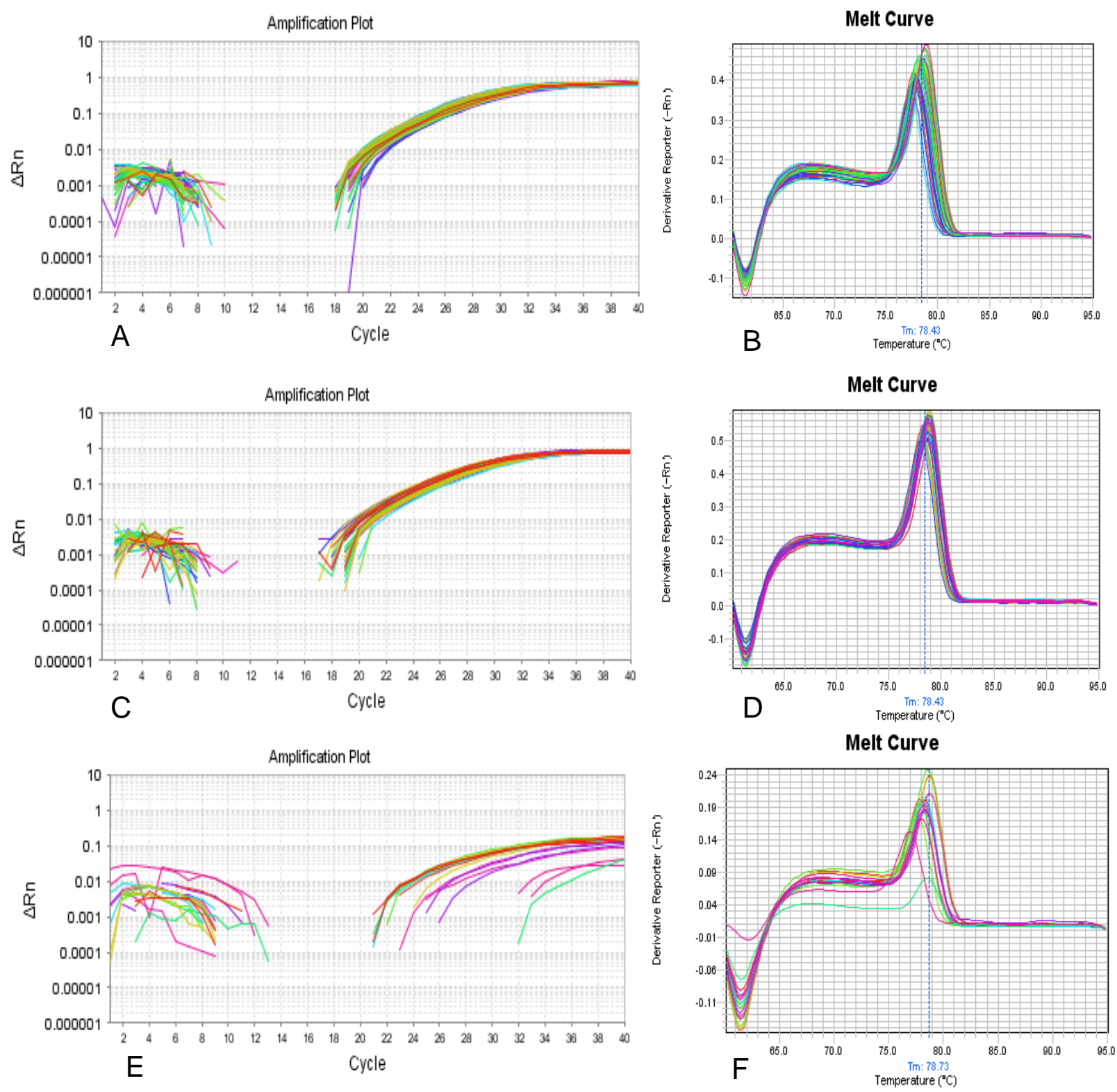

Todas as amostras de RNA foram analisadas pelo NanoDrop quanto à sua qualidade em relação à absorbância para 260/280nm. Aquelas cujas relações foram menores que 1,8 ou maiores que 2,1 foram re-extraídas.

Os kits de extração RNAid e RNAqueous (Ambion), bem como o Kit de DNAse Turbo DNA-Free (Ambion) e o kit de síntese de cDNA High Capacity Reverse Transcription Kit (Applied Biosystems), demonstraram-se através do ensaio de SPUD kits apropriados para a 
realização da PCR em tempo real das amostras de milho, uma vez que as amostras submetidas ao ensaio SPUD tiveram seus Cts entre os limites estabelecidos, com exceção de poucas amostras, que após uma segunda extração demonstraram-se adequadas.

\subsubsection{Análise por qPCR}

Os genes FUM1, FUM2, FUM6, FUM7, FUM8, FUM9, FUM10, FUM11,FUM13, FUM14, FUM15, FUM16, FUM17, FUM18, FUM19 e FUM21 foram amplificados em $33,8 \%$ (123) das 364 amostras de grãos de milho provenientes das 7 coletas realizadas (52 amostras por coleta), sendo 16 amostras da coleta 1 (fase florescimento), 17 amostras da coleta 2 (fase de grão leitoso), 30 amostras da coleta 3 (fase de grão pastoso), 16 amostras da coleta 4 (fase de grão farináceo), 12 da coleta 5 (fase de grão farináceo-duro), 12 da coleta 6 (fase de maturidade fisiológica) e 20 amostras da coleta 7 (colheita final) (Figura 22).

A Figura 23 mostra a expressão média dos diferentes genes entre as 123 amostras que amplificaram todo o cluster FUM.

Figura 22. Número de amostras que amplificaram todos os genes $F U M$ estudados em cada coleta.

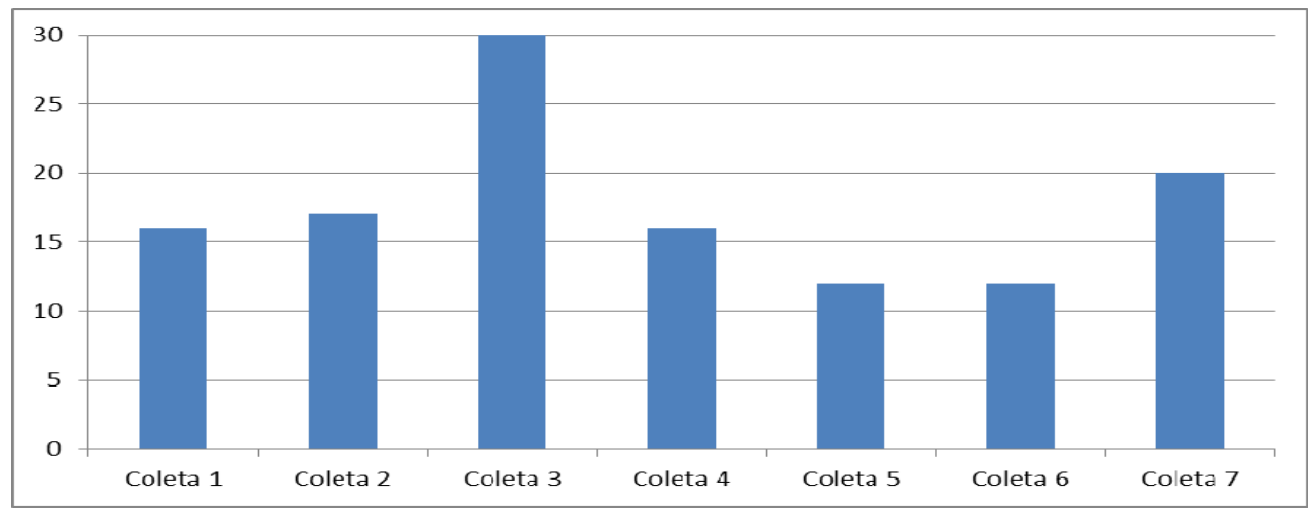


Figura 23. Expressão relativa média dos genes $F U M$ estudados em relação as 7 diferentes coletas.

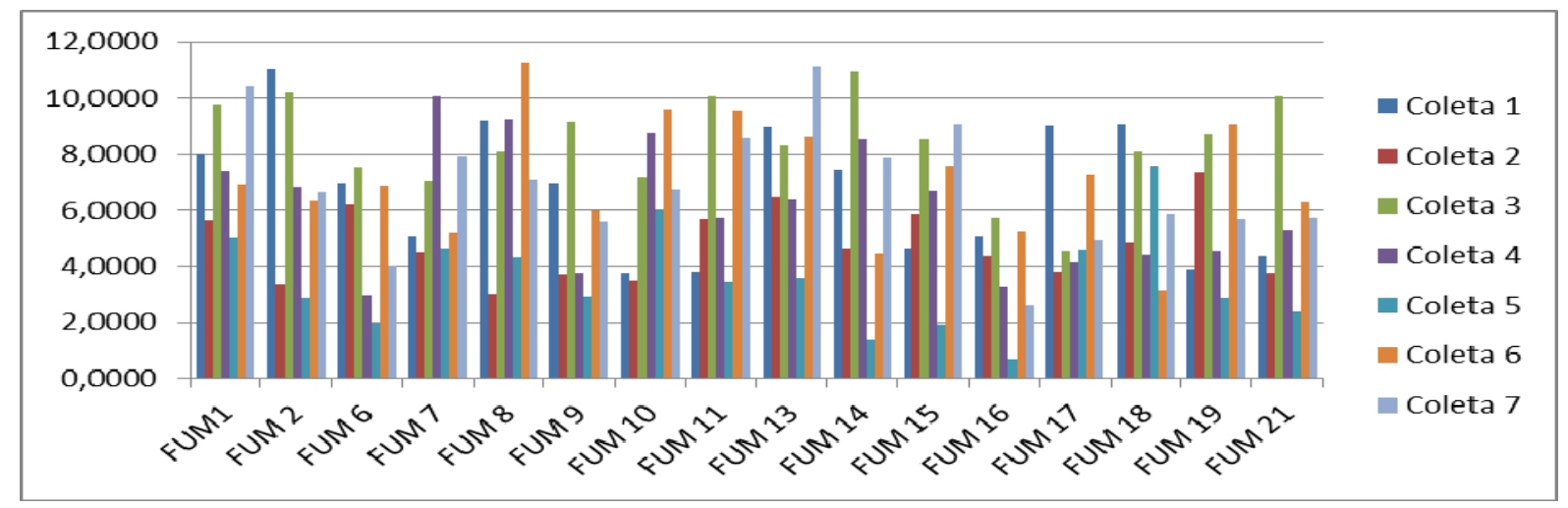

A expressão média dos genes em relação à amostra calibradora para os genes FUM1, FUM2, FUM6, FUM8, FUM10, FUM13, FUM14, FUM16, FUM17, FUM18 e FUM 21 diminuiu entre as coletas 1 e 2, porém, o oposto foi observado para os genes FUM7, FUM9, FUM11, FUM15 e FUM19. Já na coleta 3 foi observado um aumento da expressão média de todos os genes estudados. Na coleta 4 foi constatada a diminuição da expressão média dos genes estudados, com exceção dos genes FUM7, FUM8 e FUM10, nos quais foi observado o aumento da expressão média. Em relação à coleta 5, excetuando-se os genes FUM16 e FUM17, foi observada uma nova queda na expressão média em todos os genes. Já na coleta 6 foi constatado um novo aumento da expressão em todos os genes, com exceção do FUM18. $\mathrm{Na}$ coleta 7 foi observado aumento da expressão média dos genes FUM1, FUM2, FUM7, FUM13, FUM14, FUM15 e FUM18 e diminuição nos genes FUM6, FUM8, FUM9, FUM10, FUM11, FUM16,FUM17, FUM19 e FUM21 (Tabela 10 e Figuras 24 e 25).

Tabela 10. Expressão relativa média dos genes $F U M$ para as diferentes coletas e a frequência relativa de isolamento de $F$. verticillioides nas respectivas coletas.

\begin{tabular}{|c|c|c|c|c|c|c|c|c|c|c|c|c|c|c|c|c|c|}
\hline COLETA & $\begin{array}{c}\text { FUM } \\
1 \\
\end{array}$ & $\begin{array}{c}\text { FUM } \\
2 \\
\end{array}$ & $\begin{array}{c}\text { FUM } \\
6 \\
\end{array}$ & $\begin{array}{c}\text { FUM } \\
7 \\
\end{array}$ & $\begin{array}{c}\text { FUM } \\
8 \\
\end{array}$ & $\begin{array}{c}\text { FUM } \\
9 \\
\end{array}$ & $\begin{array}{c}\text { FUM } \\
10 \\
\end{array}$ & $\begin{array}{c}\text { FUM } \\
11 \\
\end{array}$ & $\begin{array}{c}\text { FUM } \\
13 \\
\end{array}$ & $\begin{array}{c}\text { FUM } \\
14 \\
\end{array}$ & $\begin{array}{c}\text { FUM } \\
15 \\
\end{array}$ & $\begin{array}{c}\text { FUM } \\
16 \\
\end{array}$ & $\begin{array}{c}\text { FUM } \\
17 \\
\end{array}$ & $\begin{array}{c}\text { FUM } \\
18 \\
\end{array}$ & $\begin{array}{c}\text { FUM } \\
19 \\
\end{array}$ & $\begin{array}{c}\text { FUM } \\
21 \\
\end{array}$ & $\begin{array}{c}\text { Freq. } \\
\text { F.v. } \\
(\%)^{*}\end{array}$ \\
\hline Coleta 1 & 7,98 & 11,00 & 6,97 & 5,08 & 9,16 & 6,98 & 3,76 & 3,81 & 9,00 & 7,44 & 4,67 & 5,10 & 9,05 & 9,11 & 3,92 & 4,35 & 9,60 \\
\hline Coleta 2 & 5,63 & 3,37 & 6,22 & 4,52 & 3,01 & 3,70 & 3,47 & 5,71 & 6,49 & 4,65 & 5,88 & 4,36 & 3,82 & 4,83 & 7,34 & 3,75 & 1,92 \\
\hline Coleta 3 & 9,75 & 10,23 & 7,52 & 7,04 & 8,11 & 9,13 & 7,19 & 10,09 & 8,34 & 10,96 & 8,51 & 5,75 & 4,56 & 8,10 & 8,69 & 10,06 & 59,62 \\
\hline Coleta 4 & 7,37 & 6,80 & 2,93 & 10,09 & 9,21 & 3,74 & 8,77 & 5,73 & 6,41 & 8,53 & 6,68 & 3,30 & 4,15 & 4,43 & 4,56 & 5,29 & 76,92 \\
\hline Coleta 5 & 5,02 & 2,85 & 1,98 & 4,64 & 4,33 & 2,91 & 5,96 & 3,44 & 3,57 & 1,42 & 1,92 & 0,72 & 4,61 & 7,58 & 2,85 & 2,40 & 96,15 \\
\hline Coleta 6 & 6,89 & 6,33 & 6,86 & 5,21 & 11,23 & 5,98 & 9,58 & 9,55 & 8,63 & 4,46 & 7,57 & 5,28 & 7,23 & 3,13 & 9,07 & 6,29 & 94,23 \\
\hline Coleta 7 & 10,42 & 6,62 & 4,03 & 7,91 & 7,13 & 5,60 & 6,72 & 8,55 & 11,10 & 7,88 & 9,07 & 2,61 & 4,95 & 5,88 & 5,70 & 5,72 & 96,15 \\
\hline
\end{tabular}


Figura 24. Média da expressão relativa entre as 123 amostras qe amplificaram os genes FUM.

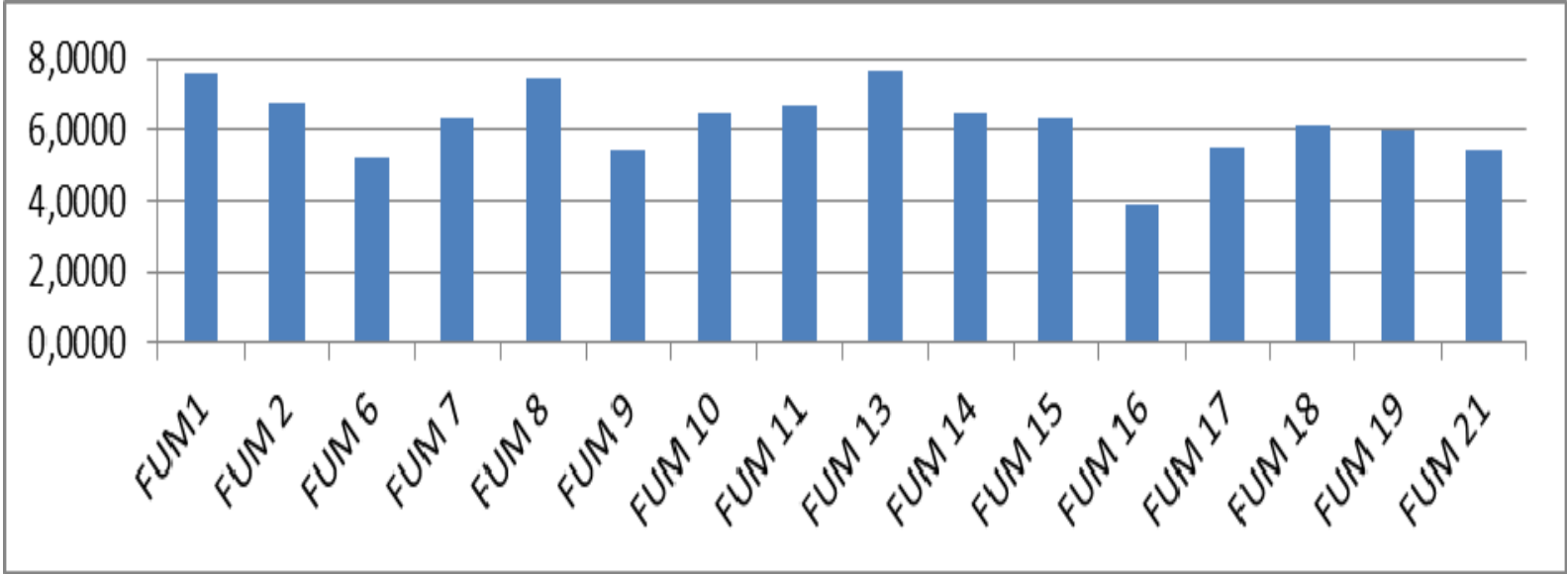

Figura 25. Variação na expressão relativa média dos genes $F U M$ nas 7 coletas realizadas.

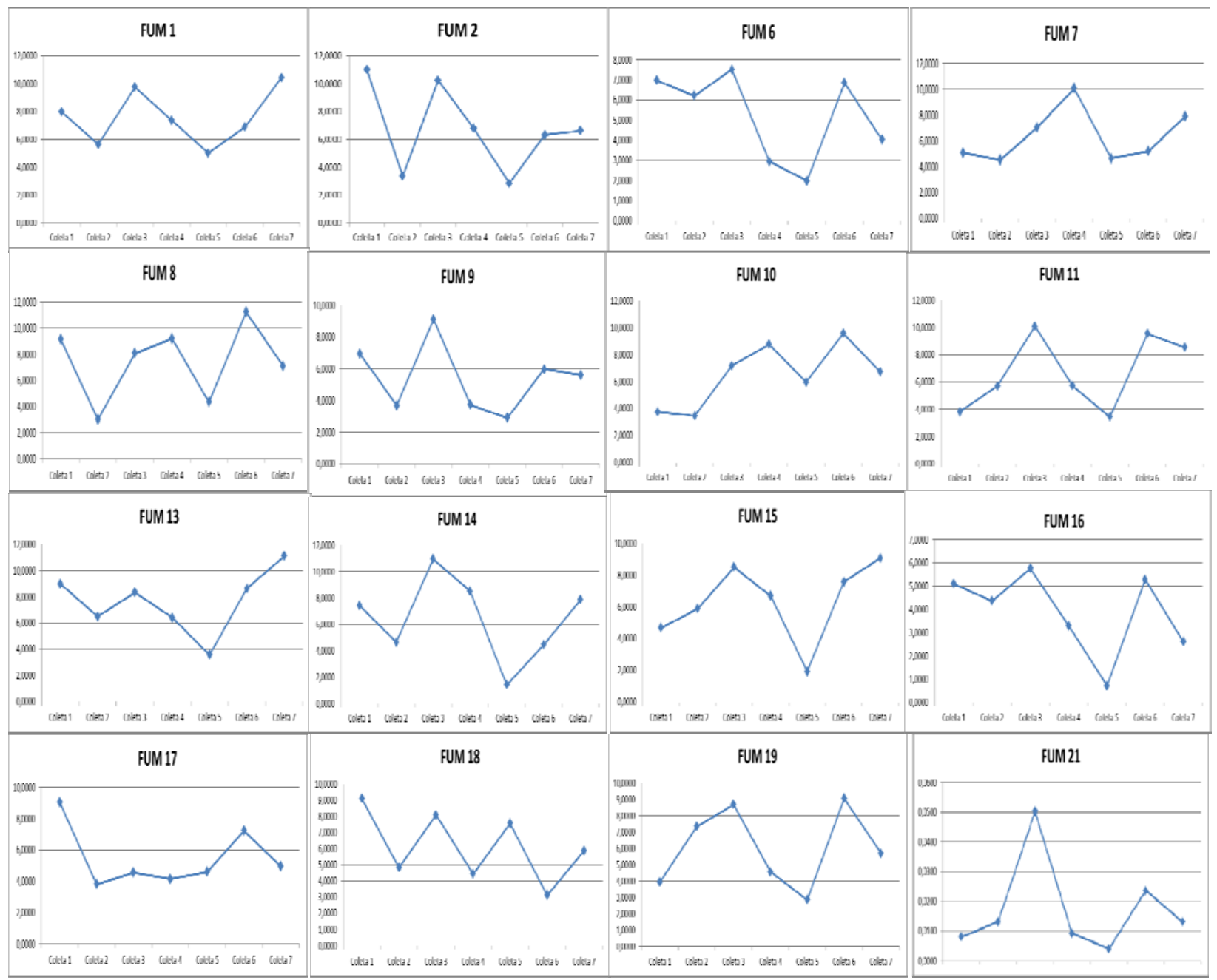


As expressões médias para todas as amostras em relação à amostra calibradora (aquela que menos expressou) foram de 7,58 vezes maior para o gene $F U M 1,6,74$ vezes maior para o gene FUM2, 5,22 vezes para o gene FUM6, 6,35 para o gene $F U M 7,7,45$ para o gene FUM8, 5,43 vezes para o gene FUM9, 6,49 para FUM10, 6,7 para FUM11, 7,65 para FUM13, 6,48 para FUM14, 6,33 para FUM15, 3,88 para $F U M 16,5,48$ para $F U M 17,6,15$ para $F U M 18,6,02$ para $F U M 19$ e 5,41 para FUM21. As expressões relativas das amostras de cada coleta estão nas Tabelas B.8 a B.14 (APÊNDICE B).

\subsection{Análises estatísticas}

\subsubsection{Fase 1}

\subsubsection{Análise do isolamento de $\underline{F \text {. verticillioides }}$}

A Tabela 11 apresenta os resultados do ajuste do isolamento de $F$. verticillioides e a Tabela 12 apresenta os valores-p das variáveis não incluídas no modelo. Pode-se notar que a proporção de grãos de milho transgênicos híbrido 2B710 HX que contém $F$. verticillioides varia de forma quadrática em função do tempo $(\mathrm{p}<0,0001)$. Porém, não há indícios de que a proporção de grãos de milho que contém $F$. verticillioides varie em função da atividade de água $(\mathrm{p}=0,747)$, da temperatura $(\mathrm{p}=0,354)$, da umidade $(\mathrm{p}=0,193)$ e da precipitação $(\mathrm{p}=$ $0,281)$.

Tabela 11. Estimativas e valores-p do ajuste do modelo de regressão beta binomial para a variável crescimento de $F$. verticillioides.

\begin{tabular}{cccrcrr}
\hline Parâmetro & Variável & Efeito & Estimativa & $\begin{array}{c}\text { Erro } \\
\text { padrão }\end{array}$ & Valor-p & $\begin{array}{r}\text { Exp. da } \\
\text { estimativa }\end{array}$ \\
\hline Média & Intercepto & & $-0,2609$ & 0,0939 & & \\
& Tempo & Linear & 0,1874 & 0,0162 & $<0,0001$ & 1,21 \\
& & Quadrático & $-0,0059$ & 0,0007 & $<0,0001$ & 0,99 \\
\hline
\end{tabular}


Tabela 12. Valores-p das variáveis não incluídas no modelo de regressão beta binomial para a variável crescimento de $F$. verticillioides.

\begin{tabular}{cr}
\hline Variável & Valor-p \\
\hline Atividade de água & 0,747 \\
Temperatura & 0,354 \\
Umidade & 0,193 \\
Precipitação & 0,281 \\
\hline
\end{tabular}

\subsubsection{Análise da contaminação dos grãos de milho por $F_{B}$}

A Tabela 13 apresenta os resultados do ajuste da produção de $F_{1}$ e a Tabela 14 apresenta os valores-p das variáveis não incluídas no modelo. Pode-se notar que a média da produção de $\mathrm{FB}_{1}$ em grãos de milho transgênicos híbrido 2B710 HX varia em função do tempo $(\mathrm{p}<0,0001)$ e do isolamento de $F$. verticillioides $(\mathrm{p}<0,0001)$. Porém, não há indícios de que a média da produção de $\mathrm{FB}_{1}$ varie em função da atividade de água $(\mathrm{p}=0,649)$, da temperatura $(p=0,199)$, da umidade $(p=0,161)$ e da precipitação $(p=0,232)$.

Tabela 13. Estimativas e valores-p do ajuste do modelo de regressão Gaussiana Inversa para a variável produção de $\mathrm{FB}_{1}$.

\begin{tabular}{cccrcrc}
\hline Parâmetro & Variável & Nível & Estimativa & $\begin{array}{c}\text { Erro } \\
\text { padrão }\end{array}$ & Valor-p & $\begin{array}{c}\text { Exp. da } \\
\text { estimativa }\end{array}$ \\
\hline Média & Intercepto & & $-1,8081$ & 0,0718 & \\
& Tempo & Grão pastoso & 0,7690 & 0,1904 & \\
& & Grão farináceo & $-0,6161$ & 0,1251 & 2,1577 \\
& & F. duro/M. fisiol. & $-1,0031$ & 0,1551 & $<, 0001$ & 0,5401 \\
& & Colheita & 1,0896 & 0,3205 & 0,3667 \\
& & & 0,0146 & $0,0023<0,0001$ & 2,9731 \\
& F. verticillioides & & 0,0147 \\
\hline Dispersão & Intercepto & & 0,0051 & $0,0011<0,0001$ & 1,0051 \\
& F. verticillioides & & & & \\
\hline
\end{tabular}

Tabela 14. Valores-p das variáveis não incluídas no modelo de regressão Gaussiana Inversa para a variável produção de $\mathrm{FB}_{1}$.

\begin{tabular}{cr}
\hline Variável & Valor-p \\
\hline Atividade de água & 0,649 \\
Temperatura & 0,199 \\
Umidade & 0,161 \\
Precipitação & 0,232 \\
\hline
\end{tabular}


Para a produção de $\mathrm{FB}_{1}$, a análise descritiva não sugeriu um comportamento bem definido do crescimento ou decrescimento da média da produção de $\mathrm{FB}_{1}$ a medida que o grão de milho vai se desenvolvendo. Em função disso, para essa variável foi necessário considerar um modelo inicial com a variável fase definida como variável qualitativa com 7 níveis e sem as variáveis climatológicas. Em seguida, comparou-se as fases em relação à média da produção de $\mathrm{FB}_{1}$, agrupou-se as fases equivalentes e posteriormente testou-se, um a um, os efeitos das variáveis climatológicas.

Pode-se notar na Tabela 13 que, mantida a porcentagem de isolamento de $F$. verticillioides constante, não há indícios de a produção de $\mathrm{FB}_{1}$, em média, seja diferente entre as fases de florescimento e grão leitoso e entre as fases de farináceo-duro e maturidade fisiológica. Observando-se a última coluna da Tabela 13, estima-se que, mantida a porcentagem de isolamento de $F$. verticillioides constante, a média da produção de $\mathrm{FB}_{1}$ na fase de grão pastoso e na fase de colheita são, respectivamente, 2,2 vezes e 3 vezes a média da produção de $\mathrm{FB}_{1}$ nas duas primeiras fases. Porém, mantida a porcentagem de isolamento de $F$. verticillioides constante, a produção de $\mathrm{FB}_{1}$ nas fases 5 e 6 , em média, é menor do que nas fase 1 e 2 . Observando ainda a terceira coluna da Tabela 13, pode-se notar que estima-se que a média da produção de $\mathrm{FB}_{1}$ seja moderada na fase de grão pastoso, alta na fase de colheita e baixa nas demais.

Em relação ao crescimento fúngico, estima-se que a cada aumento de um ponto percentual de isolamento de $F$. verticillioides, a produção de $\mathrm{FB}_{1}$ aumente, em média, 1,5\% (Tabela 13).

\subsubsection{Análise da contaminação dos grãos de milho por $\mathrm{FB}_{2}$}

A Tabela 15 apresenta os resultados do ajuste da produção de $\mathrm{FB}_{2}$ e a Tabela 16 apresenta os valores-p das variáveis não incluídas no modelo. Como a produção de $\mathrm{FB}_{2}$ é uma variável contínua com elevado número de zeros, ajustou-se em um único modelo a proporção de amostras que não contém $\mathrm{FB}_{2}$ e a média da produção de $\mathrm{FB}_{2}$, quando a amostra contém essa micotoxina. Pode-se notar que a média da produção de $\mathrm{FB}_{2}$ em grãos de milho transgênicos híbrido 2B710 HX quando a amostra contém essa micotoxina varia em função do tempo $(\mathrm{p}<0,0001)$ e do isolamento de F. verticillioides $(\mathrm{p}=0,0124)$. Porém, não há indícios de que a média da produção de $\mathrm{FB}_{2}$, quando a amostra contém essa micotoxina, varia em função da atividade de água $(\mathrm{p}=0,223)$, da temperatura $(\mathrm{p}=0,829)$, da umidade $(\mathrm{p}=$ $0,067)$ e da precipitação $(p=0,549)$. Pode-se notar ainda que a proporção de amostras que 
não contém $\mathrm{FB}_{2}$ em grãos de milho transgênicos híbrido 2B710 HX varia em função do tempo ( $\mathrm{p}<0,0001)$, do isolamento de $F$. verticillioides $(\mathrm{p}=0,0002)$ e da precipitação $(\mathrm{p}=0,0002)$. No entanto, não há indícios de que a proporção de amostras que não contém $\mathrm{FB}_{2}$ varie em função da atividade de água $(\mathrm{p}=0,444)$, da temperatura $(\mathrm{p}=0,747)$ e da umidade $(\mathrm{p}=0,365)$.

Tabela 15. Estimativas e valores-p do ajuste do modelo de regressão Gama inflacionado no zero para a variável produção de $\mathrm{FB}_{2}$.

\begin{tabular}{ccrrrr}
\hline Parâmetro & Variável & Estimativa & $\begin{array}{c}\text { Erro } \\
\text { padrão }\end{array}$ & Valor-p & $\begin{array}{r}\text { Exp. da } \\
\text { estimativa }\end{array}$ \\
\hline Média dos & Intercepto & $-5,1260$ & 0,4783 & & \\
valores & Tempo & 0,0701 & 0,0095 & $<0,0001$ & 1,0726 \\
positivos & F. verticillioides & 0,0117 & 0,0047 & 0,0124 & 1,0118 \\
\hline Probabilidade & Intercepto & 3,4695 & 0,6886 & & 32,1210 \\
de assumir o & Tempo & $-0,0533$ & 0,0133 & $<0,0001$ & 0,9481 \\
valor 0 & F. verticillioides & $-0,0262$ & 0,0074 & 0,0002 & 0,9742 \\
& Precipitação & 0,1683 & 0,0464 & 0,0002 & 1,1833 \\
\hline
\end{tabular}

Tabela 16. Valores-p das variáveis não incluídas no modelo de regressão Gama inflacionado no zero para a variável produção de $\mathrm{FB}_{2}$.

\begin{tabular}{ccr}
\hline Parâmetro & Variável & Valor-p \\
\hline Média dos & Atividade de água & 0,223 \\
valores & Temperatura & 0,829 \\
positivos & Umidade & 0,067 \\
& Precipitação & 0,549 \\
\hline Probabilidade & Atividade de água & 0,444 \\
de assumir o & Temperatura & 0,747 \\
valor 0 & Umidade & 0,365 \\
\hline
\end{tabular}

Observando-se a última coluna da Tabela 15, estima-se que, mantida a porcentagem de isolamento de $F$. verticillioides constante, a produção de $\mathrm{FB}_{2}$ aumente, em média, 7,3\% a cada dia. Estima-se também que, fixado um determinado dia, a produção de $\mathrm{FB}_{2}$ aumente, em média, $1,2 \%$ a cada aumento de um ponto percentual no isolamento de $F$. verticillioides.

Conclusões semelhantes podem ser obtidas para a proporção de amostras que não contém $\mathrm{FB}_{2}$. Estima-se que, mantidas a porcentagem de isolamento de $F$. verticillioides e a precipitação constantes, a chance de uma amostra não conter $\mathrm{FB}_{2}$ diminui 5,2\% por dia. Mantidas as demais variáveis constantes, estima-se também que a chance de uma amostra não 
conter $\mathrm{FB}_{2}$ diminui $2,6 \%$ a cada aumento de um ponto percentual no isolamento de $F$. verticillioides e aumente $18 \%$ a cada aumento de $1 \mathrm{~mm}$ na precipitação.

Estima-se que a média da produção de $\mathrm{FB}_{2}$ seja moderada na fase de colheita final e baixa nas demais.

\subsubsection{Fase 2}

\subsubsection{Análise do isolamento de $\underline{F}$. verticillioides}

A Tabela 17 apresenta os valores-p das variáveis de valores da expressão gênica do cluster FUM no ajuste de isolamento de $F$. verticillioides. Nota-se que a proporção de grãos de milho dos quais foram isolados $F$. verticillioides varia em função do valor de expressão gênica do gene $F U M 13$ (p=0,030). Porém, não há indícios de que esta proporção varie em função dos demais genes $F U M(\mathrm{p}>0,22$ em todos os casos).

Tabela 17. Valores-p das variáveis de valor da expressão dos genes $F U M$ no modelo de regressão beta binomial inflacionado no zero para a variável crescimento de $F$. verticillioides.

\begin{tabular}{cr}
\hline Variável & Valor-p \\
\hline FUM13 & 0,030 \\
\hline FUM1 & 0,412 \\
FUM2 & 0,782 \\
FUM6 & 0,762 \\
FUM7 & 0,530 \\
FUM8 & 0,810 \\
FUM9 & 0,762 \\
FUM10 & 0,294 \\
FUM11 & 0,828 \\
FUM14 & 0,868 \\
FUM15 & 0,755 \\
FUM16 & 0,612 \\
FUM17 & 0,470 \\
FUM18 & 0,229 \\
FUM19 & 0,625 \\
FUM21 & 0,716 \\
\hline
\end{tabular}




\subsubsection{Análise da contaminação dos grãos de milho por $F B_{1}$}

A Tabela 18 apresenta os valores-p das variáveis de valor de expressão dos genes $F U M$ no ajuste da produção de $\mathrm{FB}_{1}$. Nota-se que a média da contaminação por $\mathrm{FB}_{1}$ nos grãos de milho varia em função do valor da expressão gênica do $F U M 10(\mathrm{p}=0,007)$. Porém, não há indícios de que a média contaminação por $\mathrm{FB}_{1}$ nos grãos varie em função dos demais genes $F U M(\mathrm{p}>0,19$ em todos os casos).

Tabela 18, Valores-p das variáveis de valor da expressão dos genes $F U M$ no modelo de regressão Gaussiana Inversa para a variável produção de $\mathrm{FB}_{1}$.

\begin{tabular}{cr}
\hline Variável & Valor-p \\
\hline FUM10 & 0,007 \\
\hline FUM1 & 0,589 \\
FUM2 & 0,733 \\
FUM6 & 0,271 \\
FUM7 & 0,226 \\
FUM8 & 0,196 \\
FUM9 & 0,474 \\
FUM11 & 0,383 \\
FUM13 & 0,506 \\
FUM14 & 0,804 \\
FUM15 & 0,820 \\
FUM16 & 0,490 \\
FUM17 & 0,935 \\
FUM18 & 0,769 \\
FUM19 & 0,779 \\
FUM21 & 0,999 \\
\hline
\end{tabular}

\subsubsection{Análise da contaminação dos grãos de milho por $\mathrm{FB}_{2}$}

A Tabela 19 apresenta os valores-p das variáveis de valor da expressão gênica do cluster FUM no ajuste da contaminação por $\mathrm{FB}_{2}$. Nota-se que a média da contaminação por $\mathrm{FB}_{2}$ nos grãos de milho, quando contém esta micotoxina, varia em função da expressão do gene FUM $10(\mathrm{p}=0,0011)$. Porém, não há indícios que a média da contaminação por $\mathrm{FB}_{2}$, quando a amostra contém esta micotoxina, varie em função dos demais genes $F U M$ (p $>0,06$ em todos os casos). Nota-se ainda que a proporção de amostras que não contém $\mathrm{FB}_{2}$ varia em função da expressão do gene $F U M 9(\mathrm{p}=0,0002)$. No entanto, não há indícios de que a 
proporção de amostras que não contém $\mathrm{FB}_{2}$ varie em função dos demais genes $F U M(\mathrm{p}>0,09$ em todos os casos).

Tabela 19. Valores-p das variáveis de valor da expressão dos genes $F U M$ no modelo de regressão Gama inflacionado no zero para a variável produção de $\mathrm{FB}_{2}$.

\begin{tabular}{|c|c|c|c|}
\hline \multicolumn{4}{|c|}{ Parâmetro } \\
\hline $\begin{array}{l}\text { Médi } \\
\text { valores p }\end{array}$ & $\begin{array}{l}\text { dos } \\
\text { ostitivos }\end{array}$ & $\begin{array}{l}\text { Probablic } \\
\text { assumir }\end{array}$ & $\begin{array}{l}\text { lade de } \\
\text { valor } 0\end{array}$ \\
\hline Variável & Valor-p & Variável & Valor-p \\
\hline FUM10 & 0,0011 & FUM9 & 0,0002 \\
\hline FUM1 & 0,7200 & FUM1 & 0,8720 \\
\hline FUM2 & 0,2624 & FUM2 & 0,0959 \\
\hline FUM6 & 0,1972 & FUM6 & 0,1349 \\
\hline FUM7 & 0,3576 & FUM7 & 0,5398 \\
\hline FUM8 & 0,2132 & FUM8 & 0,5447 \\
\hline FUM9 & 0,5113 & FUM10 & 0,9186 \\
\hline FUM11 & 0,2559 & FUM11 & 0,8020 \\
\hline FUM13 & 0,9230 & FUM13 & 0,8871 \\
\hline FUM14 & 0,7702 & FUM14 & 0,2325 \\
\hline FUM15 & 0,0685 & FUM15 & 0,3110 \\
\hline FUM16 & 0,2100 & FUM16 & 0,1404 \\
\hline FUM17 & 0,7055 & FUM17 & 0,8775 \\
\hline FUM18 & 0,6356 & FUM18 & 0,7733 \\
\hline FUM19 & 0,1356 & FUM19 & 0,6475 \\
\hline FUM21 & 0,3949 & FUM21 & 0,2147 \\
\hline
\end{tabular}

\subsection{3 $\underline{\text { Fase } 3}$}

As tabelas 20 e 21 apresentam a distribuição de frequências da variável amplificou ou não todos os genes FUM segmentada, respectivamente, por fase de desenvolvimento do milho e por faixa de valor da variável porcentagem de isolamento de $F$. verticillioides. Nota-se que de forma descritiva, a probabilidade de amplificação de todos os genes FUM parece variar em função da fase de desenvolvimento do milho, já que a porcentagem de amostras em que todos os genes FUM forma amplificados foi consideravelmente maior na fase de grão pastoso do que nas demais. Porém, de forma descritiva, a probabilidade de amplificação de todos os genes $F U M$ não parece variara em função do isolamento de $F$. verticillioides, já que a porcentagem de amostras em que todos os genes FUM foram amplificados foi semelhante 
entre as amostras que tiveram pouca, moderada ou alta proporção de grãos contaminados com essa espécie fúngica.

Tabela 20. Distribuição de frequências da variável amplificou ou não todos os genes $F U M$ segmentada por fase de desenvolvimento do milho.

\begin{tabular}{crrrr}
\hline \multirow{2}{*}{ Fase } & \multicolumn{4}{c}{ Amplificou todos os genes FUM } \\
\cline { 2 - 5 } & \multicolumn{3}{c}{ Não } & \multicolumn{3}{c}{ Sim } \\
\cline { 2 - 5 } & $\#$ & $\%$ & $\#$ & $\%$ \\
\hline Florescimento & 36 & 69,2 & 16 & 30,8 \\
Grão leitoso & 35 & 67,3 & 17 & 32,7 \\
Grão pastoso & 23 & 44,2 & 29 & 55,8 \\
Grão farináceo & 36 & 69,2 & 16 & 30,8 \\
Farináceo-duro & 40 & 76,9 & 12 & 23,1 \\
Mat. fisiológica & 40 & 76,9 & 12 & 23,1 \\
Colheita & 32 & 61,5 & 20 & 38,5 \\
\hline
\end{tabular}

Tabela 21. Distribuição de frequências da variável amplificou ou não todos os genes $F U M$ segmentada por faixa de valor da variável crescimento de $F$. verticillioides.

\begin{tabular}{crrrr}
\hline \multirow{2}{*}{$\begin{array}{c}\text { Crescimento } \\
\text { de }\end{array}$} & \multicolumn{3}{c}{ Amplificou todos os genes FUM } \\
\cline { 2 - 5 } F.verticillioides & \multicolumn{2}{c}{ Não } & \multicolumn{3}{c}{ Sim } \\
\cline { 2 - 5 } 0 & $\#$ & $\%$ & $\#$ & $\%$ \\
\hline 0,1 a 20 & 95 & 68,8 & 43 & 31,2 \\
20,1 a 40 & 18 & 54,6 & 15 & 45,5 \\
40,1 a 60 & 28 & 62,2 & 17 & 37,8 \\
60,1 a 80 & 26 & 70,3 & 11 & 29,7 \\
80,1 a 99,9 & 39 & 65,0 & 21 & 35,0 \\
100 & 21 & 70,0 & 9 & 30,0 \\
& 15 & 71,4 & 6 & 28,6 \\
\hline
\end{tabular}

A Tabela 22 apresenta os valores-p do ajuste do modelo. Nota-se que a probabilidade de amplificação de todos os genes $F U M$ varia em função da fase de desenvolvimento do milho (p $=0,0106)$. Porém, não há indícios de que a probabilidade de amplificação de todos os genes FUM varia em função do isolamento de $F$. verticillioides $(\mathrm{p}=0,0899)$. 
Tabela 22. Valores-p das variáveis de interesse no modelo de regressão logística para a variável amplificou ou não todos os genes FUM.

\begin{tabular}{cc}
\hline Variável & Valor-p \\
\hline Fase & 0,0106 \\
F. Verticilliodes & 0,0899 \\
Interação & 0,3811 \\
\hline
\end{tabular}

Considerando o método de Benferroni, só são consideradas diferentes as fases para as quais o valor-p é inferior a 0,0024 (0,05 dividido por 21 comparações) na Tabela 23. Assim, a probabilidade de amplificação de todos os genes $F U M$ é maior na fase de grão pastoso do que nas fases de grão farináceo-duro e maturidade fisiológica ( $p=0,0009$ para ambas as comparações). Porém, não há indícios de que haja diferença entre as demais fases de desenvolvimento do milho em relação à probabilidade de amplificação de todos os genes FUM.

Tabela 23. Valores-p das comparações múltiplas no modelo de regressão logística para a variável amplificou ou não todos os genes FUM.

\begin{tabular}{cccccccc}
\hline Coleta & \multicolumn{7}{c}{ Coleta } \\
\cline { 2 - 7 } & 1 & 2 & 3 & 4 & 5 & 6 & 7 \\
\hline 1 & & & & & & \\
2 & 0,8332 & & & & & \\
3 & 0,0110 & 0,0190 & & & & \\
4 & 1,0000 & 0,8332 & 0,0110 & & & \\
5 & 0,3778 & 0,2761 & 0,0009 & 0,3778 & & \\
6 & 0,3778 & 0,2761 & 0,0009 & 0,3778 & 1,0000 & \\
7 & 0,4104 & 0,5392 & 0,0786 & 0,4104 & 0,0919 & 0,0919 & \\
\hline
\end{tabular}




\section{DISCUSSÃO}

Existem várias espécies fúngicas associadas à contaminação de cereais no campo, porém, os gêneros Aspergillus, Penicillium e Fusarium são os principais fungos envolvidos na contaminação de grãos de milho e na produção de micotoxinas. Tais microrganismos são provenientes da poeira, da água, das plantas infectadas, de insetos, do solo, de dejetos orgânicos de animais e de fertilizantes; entretanto, o ar e o solo, são as principais vias de dispersão utilizadas pelos fungos (ALMEIDA et al., 2002).

A presença de leveduras e de fungos filamentosos constatada nas 364 amostras de grãos de milho transgênico (2B710 HX), nas 7 fases de amadurecimento dos grãos, vem ao encontro de Almeida et al. (2002), em estudo realizado no Brasil. A elevada atividade de água das amostras (média de 0,96 a 0,99), também favoreceu o crescimento de leveduras.

Os menores percentuais de isolamento de Fusarium spp. foram constatados nas duas primeiras coletas, observando-se, a partir da terceira coleta percentuais acima de $60 \%$, com frequência máxima $(100 \%)$ na $6^{\mathrm{a}}$ coleta. Tais resultados podem ser explicados pelos elevados níveis de atividade de água detectados nas amostras. Segundo Lacey et al. (1991), a atividade de água máxima para o crescimento de F. verticillioides, espécie de Fusarium mais abundantemente encontrada em milho, é de 0,98 .

Diversos trabalhos desenvolvidos com milho convencional proveniente do Brasil, apontam o gênero Fusarium como o de maior frequência em grãos recém colhidos e armazenados (ALMEIDA et al., 2005; POZZI et al., 1995; ROCHA et al., 2009). Almeida et al. (2002) analisando a micobiota em diversos períodos de amadurecimento do grão de milho convencional, demonstraram $F$. verticillioides como fungo contaminante mais frequente.

Em 2002, Bakan et al. avaliaram a micobiota de grãos de milho Bt (expressam a toxina Cryla-(b)) e de grãos convencionais provenientes da França e da Espanha. Os resultados demonstraram $F$. verticillioides como a espécie mais frequente tanto no $\mathrm{Bt}$ como no convencional, porém, constatou-se uma massa fúngica de 4 a 18 vezes menor no milho $\mathrm{Bt}$ comparado com o isogênico. Barroso (2013) investigou a contaminação por Fusarium em 3 híbridos transgênicos $\mathrm{Bt}$ e em seus respectivos isogênicos, na fase de colheita final do agricultor, equivalente a C7 deste trabalho. No híbrido Bt 2B710 HX (expressa cry1F), mesmo híbrido deste estudo, Barroso encontrou $54,5 \%$ de contaminação, enquanto no convencional 2B710 a contaminação foi de 75,4\%, o mesmo aconteceu para o híbrido Bt 30F35YG (84\%) quando comparado com seu convencional 30F35 (92\%), porém uma relação inversa ocorreu com o híbrido Bt AG8088VTPRO (81,5\%) e o convencional AG8088 (60\%). 
Nessa investigação, os resultados indicam uma elevada contaminação por $F$. verticillioides. O estádio R3, fase de coleta do "milho verde", amplamente utilizado na culinária, a frequência de $F$. verticillioides foi de $36,54 \%$. Já na última coleta (fase de colheita final) a frequência do fungo foi de $96,15 \%$. Tais resultados são preocupantes, uma vez que nesta fase o fungo pode produzir altos níveis de fumonisinas.

Fatores abióticos também influenciam no crescimento fúngico e na produção de micotoxinas nos grãos. Dentre esses fatores, destacam-se a atividade de água e a temperatura (HURST, 2001). A temperatura ótima para o crescimento de $F$. verticillioides se encontra entre 22 a $28{ }^{\circ} \mathrm{C}$, enquanto a atividade de água mínima é de 0,87 . Para a produção de fumonisinas a Aa mínima é de 0,90 (CAHAGNIER; MELCION; RICHARD-MOLARD, 1995, CASA; REIS, 2003). Segundo Lacey et al. (1991) a umidade e a temperatura são fatores determinantes para o crescimento de microrganismos e para suas atividades metabólicas. Em nossa investigação, embora os valores médios de Aa e temperatura sejam considerados ótimos para o desenvolvimento de $F$. verticillioides, não se constatou, através da análise estatística, influência dos fatores abióticos (umidade e temperatura) na porcentagem de isolamento de $F$. verticillioides, nas diferentes fases de desenvolvimento do grão ( $\mathrm{p}>0,05$ para todos os fatores estudados). Tal fato pode ser atribuído a ausência de grandes variações nas médias de Aa, precipitação, temperatura e umidade do ar. A porcentagem de isolamento de F. verticillioides, neste trabalho, está relacionada com as características intrínsecas dos grãos nas diferentes fases de amadurecimento $(\mathrm{p}<0,0001)$.

O gene do fator de elongação 1- $\alpha$ codifica para uma parte essencial da proteína da maquinaria de translação e tem grande utilidade filogenética já que ele é altamente informativo em nível de espécie para Fusarium e até o momento nenhuma cópia não-ortóloga do gene foi descrita. Este gene é de cópia única e possui alto nível de polimorfismo entre as espécies relacionadas. Por esta razão este gene se tornou um marcador de escolha como ferramenta de identificação por um único lócus em Fusarium (GEISER et al., 2004). Neste trabalho, esse marcador demonstrou-se mais uma vez útil para identificação das espécies de Fusarium isoladas no milho.

Em relação à árvore filogenética obtida utilizando-se exons do gene TEF-1 $\alpha$ das 157 cepas de $F$. verticillioides provenientes das 7 diferentes coletas, a distribuição das cepas nos grupos demonstra, naquelas provenientes das duas primeiras coletas, uma tendência de agrupamento $(\mathrm{G} 1)$, porém as cepas provenientes das outras 5 coletas posteriores ficaram distribuídas, embora não uniformemente, entre os outros 5 grupos seguintes (Figura A.2APÊNDICE A). Claramente, há um forte componente clonal presente nesses isolados, evidente 
pelo simples fato que, baseado na sequência parcial do gene TEF-1 $\alpha$, o mesmo clone pôde ser isolado em diferentes amostras de diferentes coletas já que $F$. verticillioides, possui reprodução assexuada, com potencial recombinação não sexual entre os isolados altamente similares, o que justifica os resultados apresentados no cladograma.

A metodologia analítica para determinação das fumonisinas foi avaliada de acordo com os seguintes parâmetros: porcentagem de recuperação, limite de quantificação e limite de detecção. As curvas de calibração, utilizadas para a quantificação das fumonisinas $B_{1}$ e $B_{2}$, nas amostras de milho e nas análises do potencial toxigênico das cepas de $F$. verticillioides, demonstraram-se lineares. Os coeficientes de correlação para as curvas de calibração obtidas foram satisfatórios, uma vez que que foram maiores que 0,99 .

Segundo o European Commitee for Standardization (1999), as recuperações para fumonisinas devem encontrar-se entre 70 a $110 \%$ (DPR $\leq 20$ ), quando as concentrações variam de 0,5 a $5 \mu \mathrm{g} / \mathrm{g}$, e 60 a $120 \%$ com (DPR $\leq 30$ ), quando inferior a $0,500 \mu \mathrm{g} / \mathrm{g}$. Portanto, os resultados obtidos neste trabalho, para a otimização do método de análise de fumonisinas em grãos de milho, foram adequados.

Os resultados da pesquisa de fumonisinas no milho demonstram um aumento contínuo na média da produção de $\mathrm{FB}_{1}$ a partir da $\mathrm{C} 1$ até a $\mathrm{C} 3(0,15 ; 0,19$ e $0,41 \mu \mathrm{g} / \mathrm{g}$, respectivamente) seguida de uma queda contínua na produção entre C3 e C4 e C4 e C5 $(0,41 ; 0,12$ e $0,11 \mu \mathrm{g} / \mathrm{g}$, respectivamente) e novo aumento contínuo entre C5 e C6 e C6 e C7 (0,11;0,32 e 1,22 $\mu \mathrm{g} / \mathrm{g}$, respectivamente). Quanto à $\mathrm{FB}_{2}$, nas quatro primeiras coletas não foi possível traçar um perfil de aumento ou diminuição de produção, uma vez que praticamente não houve amostras nas quais foram detectadas fumonisina. A partir da C5 até C7 é observado o aumento contínuo do número de amostras das quais foi detectada $\mathrm{FB}_{2}$ e das médias encontradas entre essas $\operatorname{amostras}(0,19 ; 0,31$ e $0,85 \mu \mathrm{g} / \mathrm{g}$, respectivamente).

Em nosso trabalho a pesquisa de fumonisinas foi realizada em amostras coletadas desde o florescimento (C1) até 60 dias após o florescimento (C7). Almeida et al., 2002, estudando a contaminação por fumonisinas em diferentes coletas, entre 75 dias a 150 dias após o florescimento, (após maturidade dos grãos) de milho convencional em duas regiões distintas do estado de São Paulo, encontrou mais de 90\% das amostras contaminadas por $\mathrm{FB}_{1}$ com níveis entre 0,09 a $17,69 \mu \mathrm{g} / \mathrm{g}$ e mais de $60 \%$ de amostras com $\mathrm{FB}_{2}$ entre 0,05 a $5,24 \mu \mathrm{g} / \mathrm{g}$. Chulze et al. (1996), verificou a contaminação por $\mathrm{FB}_{1}$ e FB $\mathrm{FB}_{2}$ em grãos de milho convencional na Argentina entre os 45 dias após florescimento até o momento de colheita final (105 dias após florescimento) e encontrou níveis maiores de fumonisinas após 75 dias do florescimento. 
Alguns estudos sobre a ocorrência de $\mathrm{FB}_{1}$ e $\mathrm{FB}_{2}$ em milho convencional recém-colhido no Brasil apresentam amostras positivas em até 92,3\% e 81\%, respectivamente. Nesses estudos, as amostras revelaram médias de até 4,9 $\mu \mathrm{g} / \mathrm{g}$ para $\mathrm{FB}_{1}$ e de 3,9 $\mu \mathrm{g} / \mathrm{g}$ para $\mathrm{FB}_{2}$ (ALMEIDA et al., 2002; HASSEGAWA et al., 2008; HIROOKA et al., 1996; MALLMAN; SANTURIO; DILKIN, 2001; MORENO et al., 2009; ONO et al., 2001; ONO et al., 2004; ONO et al., 2008; ORSI et al., 2000; ROCHA et al., 2009; RODRIGUEZ-AMAYA; SABINO, 2002; VAN DER WESTHUIZEN et al., 2003).

Barroso (2013), estudando o mesmo híbrido (2B710 HX) e o seu respectivo isogênico, 60 dias após o florescimento, encontrou 95\% de amostras do milho $2 \mathrm{~B} 710 \mathrm{HX}$ com $\mathrm{FB}_{1}$ com níveis entre 0,02 a $5,11 \mu \mathrm{g} / \mathrm{g}$ e $50 \%$ com $\mathrm{FB}_{2}$ com níveis entre 0,02 e 3,35 $\mu \mathrm{g} / \mathrm{g}$, enquanto no seu respectivo convencional $\mathrm{FB}_{1}$ foi encontrado em 97,5\% com valores entre 0,02 a 3,35 $\mu \mathrm{g} / \mathrm{g}$, enquanto $\mathrm{FB}_{2}$ foi encontrada em 37,5\%, com níveis entre 0,02 a 2,08 $\mu \mathrm{g} / \mathrm{g}$. Neste mesmo trabalho, outros genótipos também foram analisados, porém em todos eles não houve diferença estatística entre a produção de fumonisinas entre o transgênico e seu respectivo convencional.

Como já foi dito anteriormente, no Brasil, em 2011, a recomendação para limites máximos tolerados de $\mathrm{FB}_{1}+\mathrm{FB}_{2}$ para milho de pipoca passou a ser de $2 \mu \mathrm{g} / \mathrm{g}$ e alimentos a base de milho para alimentação infantil de $0,2 \mu \mathrm{g} / \mathrm{g}$. A partir de 2012, outros alimentos foram adicionados à resolução, como farinha de milho, creme de milho, fubá, flocos, canjica e canjiquinha, cujo limite máximo tolerado é de $2,5 \mu \mathrm{g} / \mathrm{g}$. Também foram adicionados amido de milho e outros produtos a base de milho, cujo limite máximo tolerado é de $2 \mu \mathrm{g} / \mathrm{g}$ (BRASIL, 2011).

Publicado em 22 de fevereiro de 2011, no Diário Oficial da União, a Resolução - RDC $\mathrm{N}^{\mathrm{o}} 7$ estabelece que a partir de janeiro de 2014, o limite máximo preconizado para $\mathrm{FB}_{1}+\mathrm{FB}_{2}$ em milho em grão para posterior processamento será de $5 \mu \mathrm{g} / \mathrm{g}$. Essa mesma resolução, estabelece que, a partir de janeiro de 2016, o limite máximo tolerado para $\mathrm{FB}_{1}+\mathrm{FB}_{2} \mathrm{em}$ farinha de milho, creme de milho, fubá, flocos, canjica, canjiquinha será de 1,5 $\mu \mathrm{g} / \mathrm{g}$ e em amido de milho e outros produtos a base de milho será de $1 \mu \mathrm{g} / \mathrm{g}$ (BRASIL, 2011).

Neste estudo, encontramos $23,35 \%$ das amostras com níveis de $\mathrm{FB}_{1}+\mathrm{FB}_{2}$ acima de 0,2 $\mu \mathrm{g} / \mathrm{g}$ (máximo tolerado para alimentos a base milho para alimentação infantil), sendo 12,09\% (44 amostras) pertencentes à $\mathrm{C} 3$, estádio do milho verde. Foram encontradas $2,2 \%$ das amostras contaminadas com níveis entre 1 e $2,5 \mu \mathrm{g} / \mathrm{g}$, a maioria pertencente a $\mathrm{C} 7$, colheita final do agricultor. Amostras entre 2,5 e $5 \mu \mathrm{g} / \mathrm{g}$ de $\mathrm{FB}_{1}$, somaram 3,57\%, maioria também em C7 e 6 amostras (C7) continham acima de $5 \mu \mathrm{g} / \mathrm{g}$ de $\mathrm{FB}_{1}(1,65 \%)$. Quase todas as amostras 
que extrapolaram os valores tolerados, encontram-se nas C6 e C7, uma vez que foram nessas duas coletas que obtivemos maior número de amostras contaminadas com $\mathrm{FB}_{2}$.

Segundo Henningen et al. (2000), altos níveis de fumonisinas em milho estão associados à elevada umidade relativa do ar, enquanto que Gong et al. (2009) também associou a temperatura e o índice pluviométrico à altas concentrações de fumonisinas nos grãos de milho provenientes da China. Segundo a FDA (2001), todos esses dados meteorológicos, em diferentes áreas geográficas nos períodos pré e durante colheita, influenciam nos níveis de fumonisinas em milho. Neste trabalho, a contaminação dos grãos por fumonisinas $B_{1}$ e $B_{2}$ variou em função da fase de desenvolvimento $(p<0,0001)$ e da porcentagem de $F$. verticillioides $(\mathrm{p}<0,0001)$, porém não houve indícios de que a média de $\mathrm{FB}_{1}$ nos grãos variou em função dos fatores abióticos estudados $(\mathrm{p}>0,05)$. Já para a contaminação por $\mathrm{FB}_{2}$ houve indícios da influencia da precipitação apenas $(\mathrm{p}=0,0002)$. Assim, o estágio fisiológico do grão e a biomassa fúngica foram os fatores determinantes na produção de fumonisinas nos grãos.

Os perfis toxicológicos de cepas de $F$. verticillioides se refletem nas diferenças de contaminação por fumonisinas dos grãos, nas implicações para a saúde humana e animal, no comércio internacional, no controle biológico e na compreensão da biossíntese destas micotoxinas (PROCTOR et al., 2006). Logo, o conhecimento da potencial capacidade de biossíntese de fumonisinas por cepas de diferentes regiões geográficas auxilia na prevenção da contaminação por estas toxinas (COVARELLI et al., 2012).

Assim, quanto ao potencial toxigênico das cepas isoladas neste trabalho, 100\% delas foram capazes de produzir $\mathrm{FB}_{1}$ e $\mathrm{FB}_{2}$, esse resultado corrobora com os de Ross et al. (1990), Thiel et al. (1991) e Almeida et al. (2000), que também constataram 100\% de cepas produtoras em seus estudos. Os níveis de produção variaram de 0,35 a 8975,64 $\mu \mathrm{g} / \mathrm{g}$ para FB e de 0,06 a $725,71 \mu \mathrm{g} / \mathrm{g}$ para $\mathrm{FB}_{2}$.

Segundo Almeida et al. (2005), a presença desses fungos no alimento à base de milho pode levar a uma possível contaminação por essas toxinas e se esse alimento ainda for um bom substrato para a produção dessas toxinas, com um armazenamento sob fatores abióticos adequados, os riscos da contaminação por altos níveis de fumonisinas tendem a aumentar.

Existem diversos fatores que podem influenciar na sensibilidade e na acurácia da PCR quantitativa em tempo real, sendo que a qualidade das amostras é um dos mais importantes determinantes de sua reprodutibilidade (BUSTIN; NOLAN, 2004). Os agentes inibidores podem ser provenientes de reagentes utilizados na extração dos ácidos nucléicos ou podem ser componentes das amostras que são copurificados e estes podem gerar resultados falso 
negativos (NOLAN et al., 2006). Mesmo utilizando-se métodos de extração de RNA baseados em colunas, polifenóis e polissacarídeos presentes em amostras de plantas pode tornar essas amostras inadequadas para amplificação por PCR (GALLUP et al., 2010).

O procedimento mais comum para se verificar a presença desses inibidores é utilizando um gene de referência em paralelo com o gene de interesse e relacionar suas expressões, mas neste procedimento assume-se que os dois genes são inibidos com a mesma intensidade, o que nem sempre é verdadeiro. Porém, se a curva de calibração tiver sido construída por uma amostra que não continha inibidores, os níveis de RNA mensageiro (mRNA) dessas amostras que contém inibidores serão subestimados (STAHLBERG et al., 2005).

Assim, o Ensaio SPUD desenvolvido por Nolan et al. (2006) pode ser usado para testar a presença de inibidores em qualquer tipo de amostra com exceção de amostras provenientes de $S$. tuberosum, uma vez que a sequência SPUD-A amplificada no ensaio é proveniente da batata. O teste da presença de inibidores é necessário em todas as amostras, mesmo sendo provenientes da mesma fonte biológica, pois elas podem conter diferentes níveis de substâncias inibidoras (GALLUP et al., 2010). Neste trabalho, este ensaio demonstrou-se uma ferramenta extremamente rápida e útil para verificação da qualidade e da presença de inibidores nas amostras de mRNA provenientes dos grãos de milho nas diferentes fases de amadurecimento.

De acordo com alguns autores, os genes localizados no cluster $F U M$, responsáveis pela via biosintética das fumonisinas, são estritamente relacionados com a produção das mesmas, já que todos possuem funções estruturais e não de regulação dos genes (DESJARDINS, 2006). Além disso, a expressão de $F U M 1$ e $F U M 19$ possuem relação positiva com a produção de fumonisinas (JURADO et al., 2008; LÓPEZ-ERRASQUÍN et al., 2007; ROCHA et al., 2011).

Embora a maioria das cepas de $F$. verticillioides isoladas de milho produzam $\mathrm{FB}_{1}$, $\mathrm{FB}_{2}, \mathrm{FB}_{3}$ e $\mathrm{FB}_{4}$, cepas relativamente raras com fenótipos raros de produção já foram isolados de milho, tais como cepas que não produzem fumonisinas ou cepas que só produzem $\mathrm{FB}_{2} \mathrm{e}$ $\mathrm{FB}_{4}$ ou $\mathrm{FB}_{3}$ e $\mathrm{FB}_{4}$ (DESJARDINS; PLATTNER; PROCTOR, 1996). A análise genética molecular indica que o fenótipo de produção alterado pode ser resultado da mutação de genes do grupo $F U M$, como por exemplo a mutação em $F U M 1$, um gene responsável por uma policetídio-sintase do grupo (PROCTOR et al., 2006)

Nenhum estudo envolvendo a expressão de todos os genes responsáveis pela via biosintética das fumonisinas (cluster FUM) em grãos de milho Bt nas diferentes etapas de crescimento e amadurecimento do grão foi encontrado na literatura até o momento. Como os 
nossos resultados apontam, 33,8\% das amostras expressaram todo cluster FUM, sendo que das 16 amostras expressas na fase de florescimento, apenas 3 amostras também haviam sido isoladas cepas de $F$. verticillioides (A18, A47 e A52), porém 3 amostras das quais foram isoladas $F$. verticillioides, não foram expressos os genes $F U M$. Em relação à fase de grão leitoso, das 17 amostras passíveis de extração e amplificação dos genes $F U M$, apenas em uma (A18) o fungo $F$. verticillioides foi isolado pelos métodos clássicos. Na fase de grão pastoso, das 30 amostras que foi possível observar a expressão do cluster FUM, 18 amostras foram isoladas cepas de $F$. verticillioides e de 12 amostras não foram isoladas cepas, porém não foi observada expressão em 13 amostras das quais foram isoladas $F$. verticillioides. Já na fase de grão farináceo, dentre as 16 amostras nas quais foram observadas expressões dos genes estudados, de 15 amostras foram isoladas cepas de $F$. verticillioides e apenas de uma amostra não foi isolado, porém não foi observada a expressão dos genes $F U M$ em 26 amostras das quais foram isoladas cepas de $F$. verticillioides. Na fase de grão farináceo-duro, apenas em 12 amostras foi possível a observação da expressão dos genes $F U M, 11$ amostras das quais foram isoladas cepas de $F$. verticillioides e 1 única amostra da qual não se isolou nenhuma cepa, porém 30 amostras das quais não foram observadas expressão alguma, foi possível isolar cepas de $F$. verticillioides. Em relação à fase de maturidade fisiológica, das 12 amostras que observou-se a expressão dos genes estudados, de todas elas foram isoladas cepas de $F$. verticillioides, porém outras 38 amostras de grãos de milho nas quais não foi possível a observação da expressão dos genes $F U M$, foram isoladas cepas de $F$. verticillioides das mesmas. Já na fase de colheita final, das 20 amostras com expressão observada, de todas foram isoladas $F$. verticillioides, porém de outras 27 amostras também foram isoladas $F$. verticillioides mas não foram observadas as expressões dos genes FUM.

Em uma análise prévia é possível observar que nas 2 primeiras fases de amadurecimento a análise da expressão dos genes $F U M$ demonstrou-se ser mais eficaz para detectar a presença de $F$. verticillioides do que a metodologia clássica de isolamento de $F$. verticillioides e provável produção de fumonisinas nestas amostras, uma vez que nestas duas fases, em um número muito superior de amostras foram observadas expressões desses genes em relação ao número de amostras das quais foram isoladas cepas de $F$. verticillioides, demonstrando-se útil como metodologia complementar à metodologia clássica, já que nas duas primeiras fases, a alta atividade de água $(0,99)$ desses grãos facilita o crescimento de leveduras e dificulta o isolamento de $F$. verticillioides. A partir da terceira fase essa proporção passa a diminuir e da quarta fase em diante ela se inverte, demonstrando que com a diminuição da atividade de água dos grãos a metodologia clássica passa a ser mais eficiente 
para isolamento de $F$. verticillioides do que a verificação da sua presença apenas por expressão dos genes $F U M$ nos grãos de milho.

Rocha et al. (2011), estudaram a expressão dos genes FUM1 e FUM19 e a produção de $\mathrm{FB}_{1}$ e $\mathrm{FB}_{2}$ e encontraram uma correlação positiva entre a expressão desses genes com essas toxinas, confirmando também os obtidos por Jurado et al. (2010) e Lopez-Errasquín (2007). Todos estes autores estudaram a produção de fumonisinas in vitro. Assim, a técnica de qPCR demonstra ser uma boa ferramenta para estimar o nível de produção de fumonisina pelos isolados de F. verticillioides. Porém, não há na literatura estudos envolvendo todos os genes FUM em grãos de milho $\mathrm{Bt}$ nas diferentes etapas de crescimento e amadurecimento do grão.

Neste trabalho, como demonstraram as análises estatísticas da fase 2, não foi possível obter uma correlação positiva entre e expressão dos genes $F U M$ e a porcentagem de contaminação dos grãos por $F$. verticillioides ( $p>0,22$ para todos os genes, com exceção do FUM13), bem como entre os genes $F U M$ e os níveis de contaminação dos grãos de milho por $\mathrm{FB}_{1}$ e $\mathrm{FB}_{2}(\mathrm{p}>0,19$ e $\mathrm{p}>0,06$, respectivamente, para todos os genes, com exceção do FUM10). Já a fase 3 das análises estatísticas, demonstram que a probabilidade de amplificação de todos os genes $F U M$ varia em função da fase de desenvolvimento do milho (p $=0,016$ ), sendo maior a probabilidade na fase de grão pastoso. Porém, não houve indício de que a probabilidade de amplificação de todos os genes $F U M$ varie em função da porcentagem de isolamento de $F$. verticillioides $(\mathrm{p}=0,0899)$. Assim, novamente as características intrínsecas das fases de desenvolvimento do grão parecem estar de alguma maneira envolvidas na expressão dos genes $F U M$. Mais estudos envolvendo a composição dos grãos nas diferentes fases de amadurecimento e a expressão dos genes $F U M$ nestas fases são necessários para a elucidação dessa influencia. 


\section{CONCLUSÕES}

A tecnologia $\mathrm{Bt}$ 2B710HX não foi eficaz para controle da presença de $F$. verticillioides nas fases finais de amadurecimento do grãos, uma vez que a frequência de chegou $96,15 \%$;

$\checkmark \quad$ Foi encontrada $\mathrm{FB}_{1}$ em todas as amostras, desde o florescimento, porém, os níveis mais altos estavam nas amostras das duas últimas coletas (maturidade fisiológica e coleta 7);

$\mathrm{FB}_{2}$ foi encontrada em poucas amostras nas 5 primeiras coletas, aparecendo com maior frequência e maiores níveis nas duas últimas;

$\checkmark \quad \mathrm{O}$ isolamento de F. verticillioides e a contaminação por fumonisina nos grãos variam de acordo com a fase de amadurecimento do grão no híbrido 2B710 Hx. Em especial, o isolamento de $F$. verticillioides e contaminação por fumonisinas são, em média, consideravelmente maiores na fase final;

$\checkmark \quad$ Quanto maior a massa fúngica de $F$. verticillioides, maior a produção de $\mathrm{FB}_{1}$ e $\mathrm{FB}_{2}$ no grão;

$\checkmark \quad$ Neste estudo, encontramos $23,35 \%$ das amostras com níveis de $\mathrm{FB}_{1}+\mathrm{FB}_{2}$ acima de 0,2 $\mu \mathrm{g} / \mathrm{g}$ (máximo tolerado para alimentos a base milho para alimentação infantil), embora os níveis encontrados na última coleta estejam abaixo dos níveis encontrados na literatura em milho convencional;

$\checkmark \quad$ Não se constataram correlações positivas entre a porcentagem de $F$. verticillioides, produção de $\mathrm{FB}_{1}$ e $\mathrm{FB}_{2}$ e os fatores abióticos estudados neste trabalho;

$\checkmark \quad$ No cladograma formado com a as sequências parciais do gene TEF- $1 \alpha$ as cepas provenientes das 7 fases de amadurecimento dos grãos de milho Bt foram distribuídas nos 6 grupos formados, demonstrando um forte componente clonal deste gene nestas cepas; 
$\checkmark \quad$ Não se constataram correlações positivas entre a expressão relativa dos genes $F U M$ e os percentuais de isolamento de $F$. verticillioides e os níveis de contaminação por $\mathrm{FB}_{1}$ e $\mathrm{FB}_{2}$;

$\checkmark \quad$ Constatou-se correlação positiva entre a probabilidade de amplificação dos genes FUM e a fase de amadurecimento do grão, sendo a maior probabilidade alcançada na fase de grão pastoso;

$\checkmark \quad$ A expressão dos genes $F U M$ nas três primeiras fases, pode ser usada como ferramenta complementar (não única) para análise da presença de $F$. verticillioides, principalmente em amostras com altos níveis de atividade de água cujo isolamento por metodologias clássicas é difícil. 


\section{REFERÊNCIAS}

ABDOLLAHI, A.; BUCHANAN, R. L. Regulation of aflatoxin biosynthesis: induction of aflatoxin production by various carbohydrates. Journal of Food Science, v. 46, p. 633-635, 1981.

ALMEIDA, A. P. Potencial de contaminação do milho, com micotoxinas, da semeadura à colheita, nas regiões de Capão Bonito - SP e Ribeirão Preto - SP. 2001. Tese (Doutorado em Microbiologia) - Instituto de Ciências Biomédicas, Universidade de São Paulo, São Paulo, 2001.

ALMEIDA, A. P.; CORRÊA, B.; MALLOZZI, M. A. B.; SAWASAKI, E.; ORTEGA, E. M. Mycoflora and aflatoxin/fumonisina production by fungal isolates from freshly harvested corn hybrids. Journal of Brazilian Society for Microbiology, v. 31, p. 321-326, 2000.

ALMEIDA, A. P.; FONSECA, H.; FANCELLI, A. L.; DIREITO, G. M.; ORTEGA, E. M.; CORREAA, B. Mycoflora and fumonisin contamination in Brazilian corn from sowing to harvest. Journal of Agricutural and Food Chemistry, v. 50, n. 13, p. 3877-3882, 2002.

ALMEIDA, A. P.; SABINO, M.; FONSECA, H.; CORRÊA, B. Milho recém-colhido no Brasil: interação da microbiota fúngica, fatores abióticos e ocorrência de micotoxinas. Revista do Instituto Adolfo Lutz, v. 64, p. 1-9, 2005.

ALY, A. H.; DEBBAB, A.; KJER, J.; PROKSCH, P. Fungal endophytes from higher plants: a prolific source of phytochemicals and other bioactive natural products. Fungal Divers, v. 41, p. 1-16, 2010.

AUGUSTYNIAK, J.; DABERT, M.; WYPIJEWSKI, K. Transgenes in plants: protection against viruses and insects. Acta Physiologia Plantarum, v.19, p. 561-569, 1997.

BAKAN, B.; MELCION, D.; RICHARD-MOLARD, D.; CAHAGNIER, B. Fungal growth and Fusarium mycotoxin content in isogenic tradicional maize and genetic modified maize grown in France and Spain. Journal of Agricutural and Food Chemistry, v. 50, p. 728-731, 2002.

BARROSO, V. M. Micobiota e ocorrência de fumonisinas em diferentes genótipos de milho transgênico (Bt). 2013. Dissertação (Mestrado em Microbiologia) - Instituto de Ciências Biomédicas, Universidade de São Paulo, São Paulo, 2013.

BERJAK, P. Report of seed storage committee working group on the effects of storage fungi on seed viability. 1980-1983. Seed Scienceand Technology, v. 12, p. 233-253, 1984.

BOULDER, D. Insect pest control by copying nature using genetically engineered crops. Phytochemistry, v. 34, p. 1453-1466, 1993.

\footnotetext{
* De acordo com:

ASSOCIAÇÃO BRASILEIRA DE NORMAS TÉCNICAS. NBR 6023: informação e documentação: referências: elaboração. Rio de Janeiro, 2002.
} 
BRASIL. Ministério da Saúde. Agência Nacional de Vigilância Sanitária (Anvisa). Resolução RDC $\mathrm{n}^{0}$ 7, de 22 de fevereiro de 2011. Estabelecimento dos limites de tolerância para micotoxinas em alimentos. Diário Oficial da União, Seção 1 (n. 37), Brasília, 22 de fevereiro de 2011.

BROWN, D. W.; BUTCHKO, R. A. E.; BUSMAN, M.; PROCTOR, R. H. The Fusarium verticillioides FUM gene cluster encodes a $\mathrm{Zn}(\mathrm{II}) 2 \mathrm{Cys} 6$ protein that affects $F U M$ gene expression and fumonisin production. Eukaryotic Cell, v. 6, p. 1210-1218, 2007.

BUSTIN, S. A.; NOLAN, T. Pitfalls of quantitative real-time reverse-transcription polymerase chain reaction. Journal of Biomolecular Technology, v. 15, p. 155-166, 2004.

CAHAGNIER, B.; MELCION, D.; RICHARD-MOLARD, D. Growth of Fusarium moniliforme and its biosynthesis of fumonisin $\mathrm{B}_{1}$ on maize grain as a function of different water activities. Letters in Applied Microbiology, v. 20, p. 247-251, 1995.

CARNEIRO, A. A.; GUIMARÃES, C. T.; VALICENTE, F. H.; WAQUIL, J. M.; VASCONCELOS, M. J. V.; CARNEIRO, N. P.; MENDES, S. M. Milho Bt: Teoria e prática da produção de plantas transgênicas resistentes a insetos praga. Embrapa milho e sorgo. Sete Lagoas, 2009. 26 p. (Circular Técnica, 135).

CASA, R. T.; REIS, E. M. Doenças na cultura do milho. In: FANCELLI, A. L.; DOURADO, D. NETO. (Ed.). Milho: estratégias de manejo e alta produtividade. Piracicaba: Escola Superior da Agricultura "Luiz de Queiroz", Departamento da Produção Vegetal, 2003. p. 118.

CASTRO, A. P. Perspectivas da utilização do gene $b t$ para o controle de insetos-praga do arroz no Brasil. Embrapa arroz e feijão. Santo Antônio de Goiás, 2008. 23 p.

CENTER FOR ENVIRONMENTAL RISK ASSESSMENT. A Review of the environmental safety of the Cry1F protein. 2013. Available in: $<$ http://www.ilsi.org/ResearchFoundation/Publications/Crylf-monograph.pdf $>$. Accessed in: 28 apr. 2014.

CHRISTENSEN, C. M.; KAUFMANN, H. H. Deterioration of storage grains by fungi. Annual Review of Phytopathology, v. 3, p. 69-84, 1965.

CHULZE, S. N.; RAMIREZ, M. L.; FARNOCHI, M. C.; PASCALE, M.; VISCONTI, A.; MARCH, G. Fusarium and fumonisin occurrence in Argentinian corn at different ear maturity stages. Journal of Agricultural and Food Chemistry, v. 44, p. 2797-2801, 1996.

COMPANHIA NACIONAL DE ABASTECIMENTO (CONAB). Acompanhamento da Safra Brasileira de Grãos 2011/2012 - $\mathbf{8}^{\mathbf{0}}$ levantamento, 2012. Disponível em: $<$ http://www.cnpt.embrapa.br/conab/levantamento.pdf.> Acesso em: 24 abr. 2014.

COMPANHIA NACIONAL DE ABASTECIMENTO (CONAB). Acompanhamento da Safra Brasileira de Grãos 2013/2014 - $\mathbf{2}^{\mathbf{o}}$ levantamento, 2013. Disponível em: $<$ http://www.conab.gov.br/conteudos.php?a=1253\&t.> Acesso em: 24 abr. 2014. 
CONSELHO DE INFORMAÇÕES SOBRE BIOTECNOLOGIA. Guia do milho: tecnologia do campo à mesa. 2006. Available in $<$ http://www.cib.org.br/pdf/guia_do_milho_CIB.pdf $>$. Accessed in: 24 apr. 2014.

COVARELLI, L.; STIFANO, S.; BECCARI, G.; RAGGI, L.; LATTANZIO, V. M. T.; ALBERTINI, E. Characterization of Fusarium verticillioides strains isolated from maize in Italy: Fumonisin production, pathogenicity and genetic variability. Food Microbiology, v. 31, p. 17-24, 2012.

DEGOLA, F.; BERNI, E.; DALL'ASTA, C.; SPOTTI, E.; MARCHELLI, R.; FERRERO, I.; RESTIVO, F.M. A multiplex RT-PCR approach to detect aflatoxigenic strains of Aspergillus flavus. Journal of Applied Microbiology. v. 103, p. 409-441, 2007.

DELP, R. B.; STEWELL, L. J.; MAROIS, J. J. Evaluation of field sampling techniques for estimation of disease incidence. Phytopathology, v. 76, p. 1299-1305, 1986.

DESJARDINS, A. E.; PLATTNER, R. D.; PROCTOR, R. H. Linkage among genes responsible for fumonisin biosynthesis in Gibberella fujikuroi mating population A. Applied and Environmental Microbiology, v. 62, p. 2571-2576, 1996.

DESJARDINS, A. E. Fusarium mycotoxins: chemistry, genetics and biology. Minnesota: APS Press, 2006. 260 p.

DUVICK, J. Prospects for reducing fumonisin contamination of maize through genetic modification. Environmental Health Perspectives. v. 109, p. 337-342, 2001.

ENVIRONMENTAL PROTECTION AGENCY - US. 2005. Office of Pesticide Programs: biopesticide registration action document - Bacillus thuringiensis Cry1F Corn. Available in: $<$ bch.cbd.int/database/attachment/?id=10711>. Accessed in: 28 apr.2014.

EUROPEAN COMMITTEE FOR STANDARDIZATION. CEN/TC 275/wgs Food Analysis - Biotoxins- Criteria of Analytical Methods of Mycotoxins. CEN Report CR 13S0S, Berlin, Germany, 1999, 10p.

FANCELLI, A. J. Plantas alimentícias: guia para aula, estudos e discussão. Piracicaba: Esalq, 1986. 13 p.

FIUZA, L. M.; NIELSEN-LEROUX, C.; GOZE, E.; FRUTOS, R.; CHARLES, J. Binding of Bacillus thuringiensis Cryl toxins to the midgut brush border membrane vesicles of Chilo suppressalis (Lepidoptera:Pyralidea): evidence of shared binding sites. Applied and Environmental Microbiology, v. 62, p. 1544-1549, 1996.

FOOD AND DRUGS ADMINISTRATION (FDA). Background paper in support of fumonisin levels in corn and corn products intended for human consumption. US Food and Drug Administration, Center for Food Safety and Applied Nutrition. FDA, 2001. Available in: $<$ http://vm.cfsan.fda.gov/ dms/fumonbg1.html $>$ Accessed in: 10 feb. 2009.

GALLUP, J. M.; SOW, F. B.; VAN GEELEN, A.; ACKERMANN, M. R. SPUD qPCR assay confirms PREXCEL-Q software1s ability to avoid qPCR inhibition. Current Issues in Molecular Biology, v. 12, n. 3, p. 129-134, 2010. 
GAO, Y.; FENCIL, J. K.; XU, X.; SCHWEDLER, D. A.; GILBERT, R. J.; HERMAN, A. R. Purification and characterization of a chimeric Cry1F $\ddot{a}$-endotoxin expressed in transgenic cotton plants. Journal of Agricultural and Food Chemistry, v. 54, p. 829-835, 2006.

GEISER, D. M.; JIMENEZ-GASCO, M.; KANG, S.; MAKALOWSKA, N.; VEERARAGHAVAN, T. J.; WARD, N.; ZHANG, G. A.; KULDAU, G. A.; O'DONNELL, K. FUSARIUM-ID v.1.0: A DNA sequence database for identifying Fusarium. European Journal of Plant Pathology, v. 110, p. 473-479, 2004.

GELVIN, S. B. Agrobacterium-mediated plant transformation: the biology behind the "genejockeying” tool. Microb. Mol. Biol. Reviews, v. 67, n. 1, p. 16-37, 2003.

GIZINGER, D. G. Gene quantification using real-time quantitative PCR: an emerging technology hits the mainstream. Experimental Hematology, v. 30, p. 503-512, 2002.

GONG, H. Z.; JI, R.; LI, Y. X.; LI, B.; ZHAO, Y.; SUN, L.; YU, F.; YANG, J. Occurance of fumonisina in corn from the main corn-producing areas of China. Mycopathology, v. 167, p. 31-36, 2009.

HAMMOND, B. G.; CAMPBELl, K. W.; PILCHER, C. D.; DEGOOYER, T. A.; ROBINSON, A. E.; MC MILLEN, B. L.; SPANGLER, S. M.; RIORDAN, S. G.; RICE, L. G.; RICHARD, J.L. Lower fumonisin mycotoxin levels in the grain of Bt corn grown in the United States in 2000-2002. Journal of Agricutural and Food Chemistry, v. 52, p. 13901397, 2004.

HASSEGAWA, R. H.; FONSECA, H.; FANCELLI, A. L.; SILVA, V. N.; SCHAMMASS, E. A.; REIS, T. A.; CORREAA, B. Influence of macro - and micronutrient fertilization on fungal contamination and fumonisin production in corn grains. Food Control, v. 19, p. 36-43, 2008.

HENNIGEN, M. R.; VALENTE SOARES, L. M.; SANCHEZ, S.; DI BENEDETTO, N. M.; LONGHI, A.; EYHERABIDE, G.; TORROBA, J.; ZANELLI, M. Fumonisins in corn hybrids grown in Argentina for 2 consecutive seasons. In: DE KOE, W. J.; SAMSON, R. A.; VAN EGMOND, H. P.; GILBERT, J.; SABINO, M. (Ed.). Proceedings of the $\mathbf{1 0}^{\text {th }}$ International IUPAC Symposium on Mycotoxins and Phytotoxins. IUPAC: Guarujá, Brazil, 2000. p. 331-339.

HERRERO, S.; OPPERT, B.; FERRÉ, J. Different mechanisms of resistance to Bacillus thuringiensis toxins in the indianmeal moth. Applied and Environmental Microbiology, Washington, v. 67, p.1085-1089, 2001.

HIROOKA, E. Y.; YAMAGUCHI, M. M.; AOYAMA, S.; SUGIURA, Y.; UENO, Y. The natural occurrence of fumonisins in Brazilian corn kernels. Food Additives and Contaminants, v. 13, p. 173-183, 1996.

HOSMER, D. W.; LEMESHOW, S. Applied logistic regression. $2^{\text {nd }}$ ed. New York: John Wiley and Sons. 2000.

HURST, C. J. Manual of Environmental Microbiology. Washington, DC: American Society for Microbiology, 2001. 1158 p. 
IGNOFFO, C. M.; GREGORY, B. Effects of Bacillus thuringiensis b-exotoxina on larval maturation, adult longevity, fecundity, and egg viability in several species of lepidoptera. Environmental Entomology, v. 1, p. 269-271, 1972.

INTERNATIONAL AGENCY FOR RESEARCH ON CANCER (IARC). Some naturally occurring substances: food items and constituents, heterocyclic aromatic amines and mycotoxins. IARC. Monographs on the evaluation of carcinogenic risks to humans. Lyon: IARC, 1993. v.56, p. 445-446.

JAMES, C. Global status of commercialized Biotech/GM Crops: 2007. 2007. Disponível em: <http://www.isaaa.org/resources/publications/briefs/37/executivesummary/default.html $>$. Acesso em: 24 apr. 2014.

JOUANIN, L.; BONADÉ-BOTTINO, M.; GIRARD, C.; MORROT, G.; GIBAND, M. Transgenic plants for insect resistence - review. Plant Science, v. 131, p. 1-11, 1998.

JURADO, M.; MARÍN, P.; MAGAN, N.; GONZÁLEZ-JAÉN, M. T. Relationship between solute and matric potential stress, temperature, growth and Fuml gene expression in two Fusarium verticillioides strains from Spain. Applied and Environmental Microbiology, v. 74, p. 2032-2036, 2008.

JURADO, M.; MARÍN, P.; CALLEJA, C.; MORETTI, A.; VÁZQUEZ, C.; GONZÁLEZJAÉN, M. T. Genetic variability and fumonisina production by Fusarium proliferatum. Food Microbiology, v. 27, p. 50-57, 2010.

KHALDI, N.; WOLFE, K. H. Evolutionary origins of the fumonisin secondary metabolite gene cluster in Fusarium verticillioides and Aspergillus niger. International Journal of Evolutionary Biology, v. 2011, p. 7, 2011.

KRONSTAD, J. W.; SCHNEPF, H. E.; WHITELEY, H. R. Diversity of locations for Bacillus thuringiensis crystal protein genes. Journal of Bacteriology, v.154, p. 419-428, 1983.

LACEY, J. Airbone spores in pestures. Transactions of the British Mycological Society, v. 64, p. 1-17, 1975.

LACEY, J.; MAGAN, N. Fungi in cereal grain: their occurrence and water and temperature relations. In: CHELKOWSKI, J. (Ed.). Cereal grain: mycotoxins, fungi and quality in drying and storage. Amsterdam: Elsevier Science, 1991. p. 77-118.

LACEY, J.; RAMAKRISHMA, N.; HAMER, A.; MAGAN, N.; MARFLEET, C. Grain fungi. In: DILIP,K.; ARORA,D. K.; MUKERJI, K. G.; MARTH, E.H. (Eds.). Handbook of Applied Mycology: foods and feeds. New York: Marcel Dekker, 1991, p. 121-177.

LERAYER, A.; PATERNIANI, E.; SILVEIRA, J. M.; MENOSSI, M.; ODA, L.; DI CIERO, L. Avaliação de impactos do milho geneticamente modificado. 2011. Disponível em: $<$ http://cib.org.br/wp-content/uploads/2011/10/estudos_cientificos_ambiental_04.pdf $>$.Acesso em: 24 abr. 2014. 
LERECLUS, D. Génétique et biologie moléculaire de Bacillus thuringiensis. Bulletin de I.Institut Pasteur, v. 86, p. 337-371, 1988.

LESLIE, J. F. Introductorybiology of Fusarium moniliforme. In: JACKSON, L. S.; De VRIES, J. W.; BULlERMAN, L. B. (Ed.). Fumonisins in food. New York, Plenum Press, 1996. p. 153-164.

LESLIE, J. F.; SUMMERELL, B. A. The Fusarium laboratory manual. Iowa: Blackwell Publishing, 2006. 388 p.

LINO, C. M.; SILVA, L. J. G.; PENA, A. S. Fumonisinas: presença em alimentos, implicações na saúde e aspectos legislativos. Revista Portuguesa de Ciências Veterinárias, v. 99, p. 181-192, 2004.

LÓPEZ-ERRASQUÍN, E.; VÁZQUEZ, C.; JIMÉNEZ, M.; GONZÁLEZ-JAÉN, M. T. Realtime RT- PCR assay to quantify the expression of fum 1 and fum 19 genes from the fumonisinproducing Fusarim verticillioides. Journal of Microbiological Methods, v. 68, p. 312-317, 2007.

MAGNOLI, C. E.; SAENZ, M. A.; CHIACCHIERA, S. M.; DALCERO, A. M. Natural occurrence of Fusarium species and fumonisin-production by toxigenic strains isolated from poultry feeds in Argentina. Mycopathologia, v. 145, p. 35-41, 1999.

MALLMAN, C. A.; SANTURIO, J. M.; DILKIN, P. Fumonisin B $_{1}$ in cereals and feeds from southern Brazil. Arquivos do Instituto Biológico, v. 68, n. 1, p. 41-45, 2001.

MARASAS, W. F. O. Fumonisins: history, world-wide occurrence and impact. In: JACKSON, L. S.; De VRIES, J. W.; BULLERMAN, L. B. (Ed.). Fumonisins in food. New York, Plenum Press, 1996. p. 1-17.

MAYER, Z.; FÄRBER, P.; GEISEN,R. Monitoring the production of aflatoxin $\mathrm{B}_{1}$ in wheat by measuring the concentration of nor-1 mRNA. Applied and Environmental Microbiology, v. 69, n. 2, p. 1154-1158, 2003.

MORENO, E. C.; GARCIA, G. T.; ONO, M. A.; VIZONI, E.; KAWAMURA, O.; HIROOKA, E. Y.; ONO, E. Y. S. Co-occurrence of mycotoxins in corn samples from the Northern region of Paraná State, Brazil. Food Chemistry, v. 116, p. 220-226, 2009.

MUNKVOLD, G. P.; MCGEE, D. C.; CARLTON, W. M. Importance of different pathways for maize kernel infection by Fusarium moniliforme. Phytopathology, v. 87, p. 209-217, 1997.

MUNKVOLD, G. P.; HELlMICH, R. L.; RICE, L. G. Comparison of fumonisin concentration in kernels of transgenic Bt maize hybrids and nontransgenic hybrids. Plant Disease, v. 83, p. 130-138, 1999.

NELSON, P. E.; TOUSON, T. A.; MARASAS, W. F. O. Fusarium species. An illustrated manual for identification. Pennsylvania, University Press, 1983. 193 p. 
NELSON, P. E. Taxonomy and biology of Fusarium moniliforme. Mycopathologia, v. 117, p. 29-36, 1992.

NETER, J.; KUTNER, M. K.; NACHTSHEIM, C. J.; WASSERMAN, W. Applied linear statistical models. 4th ed. Irwin: Chicago, 1996.

NOLAN, T.; HANDS, R. E.; OGUNKOLADE, W.; BUSTIN, S. A. SPUD: A quantitative PCR assay for the detection of inhibitors in nucleic acid preparations. Analytical Biochemistry, v. 351, p. 308-310, 2006.

ONO E. Y.; ONO M. A.; FUNO, F. Y.; MEDINAL, A. E.; OLIVEIRA, T. C.; KAWAKURA, T. O.; UENO, Y.; HIROOKA E. Y. Evaluation of fumonisin-aflatoxin cooccurrence in Brazilian corn hybrids by ELISA. Food Additives and Contaminants, v. 18, n. 8, p. 719-729, 2001.

ONO, E. Y. S.; FUNGARO, M. H. P.; SOFIA, S. H.; FIGUEIRA, E. L. Z.; GERAGE, A. C.; ICHIONE, M.; SUGIURA, Y.; UENO, Y.; HIROOKA, E. Y. Trends of fumonisin contamination and animal intoxication through monitoring 1991 to 1997 corn crop in the State of Paraná, Brazil. Mycopathologia, v. 158, p. 451-455, 2004.

ONO, E. Y. S.; SILVA, M.; HASHIMOTO, E. H.; VIZONI, E.; KAWAMURA, O.; SUGIURA, Y.; HIROOKA, E. Y. Mycotoxicological quality evaluation of corn samples used by processing industries in the Northern region of Paraná State, Brazil. Food Additives and Contaminants, v. 25, p. 1-8, 2008.

ORSI, R. B.; CORREAA, B.; POZZI, C. R.; SCHAMMASS, E.; NOGUEIRA, J. R.; DIAS, S. M. C.; MALOZZI, M. Mycoflora and occurrence of fumonisins in freshly harvest and stored hybrid maize. Journal of Stored Products Research, v. 36, p. 75-87, 2000.

PAES, M. C. D. Aspectos físicos, químicos e tecnológicos do grão de milho. Embrapa milho e sorgo. Sete Lagoas, 2006. 6 p. (Circular Técnica, 75).

PAPST, C.; UTZ, A. E.; MELCHINGER, A. E.; EDER, J.; MAGG, T.; KLEIN, D.; BOHN, M. Mycotoxins produced by Fusarium spp. in isogenic Bt vs. non Bt maize hybrids under European corn borer pressure. Agronomy Journal, v. 97, p. 219-224, 2005.

PFAFFL, M. W. A new mathematical model for relative quantification in real time RT-PCR. Nucleic Acids Research, v. 29, p. 2002-2007, 2001.

PITT, J. I.; HOCKING, A. D. Fungi and food spoilage. $2^{\text {nd }}$ ed. Gaithersburg: Aspen Pub., Inc., 1997. 593 p.

PITT, J. I.; HOCKING, A. D. Fungi and food spoilage. $3^{\text {rd }}$ ed. Gaithersburg: Aspen Pub., Inc., 2009. 593 p.

POZZI, C. R.; CORRÊA, B.; GAMBALE, W.; PAULA, C. R.; CHACON-RECHE, N. O.; MEIRELLES, M. C. A. Post-harvest and stored corn in Brazil: mycoflora interection, abiotic factors and mycotoxins occurrence. Food Additives and Contaminants, v. 12, p. 313-319, 1995. 
PROCTOR, R. H.; DESJARDINS, A. E.; PLATTNER, R. D.; HOHN, T. M. A polyketide synthase gene required for biosynthesis of fumonisina mycotoxins in Gibberella fujikuroi mating population A. Fungal Genetics and Biology, v. 27, p. 100-112, 1999.

PROCTOR, R. H.; DAREN, W. B.; PLATTNER, R. D.; DESJARDINS, A. E. Co-expression of 15 contiguous genes delineates a fumonsin biosynthetic gene in Gibberella moniliformis. Fungal Genetics and Biology, v. 38, p. 237-249, 2003.

PROCTOR, R. H.; PLATTNER, R. D.; DESJARDINS, A. E.; BUSMAN, M.; BUTCHKO, R. A. E. Fumonisin production in the maize pathogen Fusarium verticillioides: Genetic basis of naturally occurring chemical variation. Journal of Agricultural and Food Chemistry, v. 54, p. 2424-2430, 2006.

RIGBY, R. A.; STASINOPOULOS, D. M. Generalized additive models for location, scale and shape. Journal of the Royal Statistical Society: Series C (Applied Statistics), v. 54, p. 507-554, 2005.

RITCHIE, S. W.; HANWAY, J. J.; BENSON, G.O. Como a planta do milho se desenvolve. In: Arquivo do Agrônomo, n.15 - Encarte do Informações agronômicas, n. 103, setembro de 2003.

ROCHA, L. O.; NAKAI, V. K.; BRAGHINI, R.; REIS, T. A.; KOBASHIGAWA, E.; CORREA, B. Mycoflora and co-occurrence of fumonisins and aflatoxins in freshly harvested corn in different regions of Brazil. International Journal of Molecular Science, v. 10, p. 5090-5193, 2009.

ROCHA, L. O.; REIS, G. M.; NASCIMENTO, V. N.; BRAGHINI, R.; TEIXEIRA, M. M. G.; CORREAA, B. Molecular characterization and fumonisin production by Fusarium verticillioides isolated from corn grains of different geographic origins in Brazil. International Journal of Food Microbiology, v. 145, p. 9-21, 2011.

ROCHA, L. O.; TRALAMAZZA, S. M.; REIS, G. M.; RABINOVITCH, L.; BARBOSA, C. B.; CORREAA, B. Multi-method approach for characterizing the interaction between Fusarium verticillioides and Bacillus thuringiensis Subsp. Kurstaki. Plos One, v. 9, p. 1-10, 2014.

RODRIGUEZ-AMAYA, D. B.; SABINO, M. Mycotoxin research in Brazil: the last decade in review. Brazilian Journal of Microbiology, v. 33, p. 1-11, 2002.

ROSS, P. F.; NELSON, P. E.; RICHARD, J. L.; PLATTNER, R. D.; RICE, L. G.; OSWEILLER, G. D.; WILSON, T. M. Production of fumonisin by Fusarium verticillioide and Fusarium proliferatum isolates associated with equine leukoencephalomalacia and pulmonary edema syndrome swine. Applied and Environmental Microbiology, v. 56, p. 3224-3226, 1990.

ROSS, R. F.; RICE, L. G.; PLATTNER, R. D.; OSWEILER, G. D.; WILSON, T. M.; OWENS, D. L.; NELSON, H. A.; RICHARD, J. L. Concentrations of fumonisin $\mathrm{B}_{1}$ in feeds associated with animal health problem. Mycopathologia, v. 114, p. 129-135, 1991. 
ROSSETTO, C. A. V.; SILVA, O. F.; ARAÚJO, A. E. S. Influência da calagem, da época de colheita e da secagem na incidência de fungos e aflatoxinas em grãos de amendoim armazenados. Ciência Rural, v. 35, n. 2, p. 309-315, 2005.

SANFORD, J.; KLEIN, T.; WOLF, E.; ALLEN, N. Delivery of substances into cells and tissues using particle bombardment process. J. Part Sci. Techn., v. 5, p. 27-37, 1987.

SCHMIDT-HEYDT, M.; ABDEL-HADI, A.; MAGAN, N.; GEISEN, R. Complex regulation of the aflatoxin biosynthesis gene cluster of Aspergillus flavus in relation to various combinations of water activity and temperature. International Journal of Food Microbiology, v. 135, p. 231-237, 2009.

SCHMITTGEN, T. D.; LIVAK, K. J. Analyzing real-time PCR data by the comparative Ct method. Nature Protocols, v. 3, p. 1101-1108, 2008.

SILLIKER, J. H.; ELLIOTT, R. P. Ecologia microbiana de los alimentos. Zaragoza: Acribia, 1980. v. 1, p. 74-96.

STAHLBERG, A.; ZORIC, N.; AMAN, P.; KUBISTA, M. Quantitative real-time PCR for cancer detection: the lymphoma case. Expert Review of Molecular Diognostics, v. 5, p. 221 $230,2005$.

SYDENHAM, E. W.; SHEPHARD, G. S.; THIEL, P. G.; SNIJMAN, P. W.; STOCKENSTRON, S. Liquid chromatographic determination of fumonisina $\mathrm{B}_{1}, \mathrm{~B}_{2}$ and $\mathrm{B}_{3}$ in corn: AOAC - IUPAC collaborative study. Journal of the Association of Official Agricultural Chemists, v. 79, p. 688-696, 1996.

THIEL, P. G.; MARASAS, W. F. O.; SYDENHAM, G. S.; GELDERBLOM, W. C. A.; NIEUWENHUIS, J. J. Survey of fumonisins production by Fusarium species. Applied and Environmental Microbiology, v. 57, p. 1089-1983, 1991.

TURNER, P. C.; NIKIEMA, P.; WILD, C. P. Fumonisin contamination of food: progress in development of biomarkers to better assess human health risks. Mutation Research, v. 443, p. 81-93, 1999.

VAN DERWESTHUIZEN, L. V.; SHEPHARD, G. S.; SCUSSEL, V. M.; COSTA, L. L.; VISMER, H. F.; RHEEDER, J. P.; MARASAS, W. F. O. Fumonisin contamination and Fusarium incidence in corn from Santa Catarina, Brazil. Journal Agricultural and Food Chemistry, v. 51, p. 5574-5578, 2003.

VISCONTI, A.; SOLFRIZZO, M.; GIROLAMO, A. Determination of fumonisins $\mathrm{B}_{1}$ and $\mathrm{B}_{2}$ in corn and corn flakes by liquid chromatography with immunoaffinity column cleanup: collaborative study. Food Chemical Contaminants, v. 84, n. 6, p. 1828-1837, 2001.

WAQUIL, J. M.; VILELLA, F. M. F.; SIEGFRIED, B.D.; FOSTER, J. E. Atividade biológica das toxinas do Bt, Cry 1 A (b), e Cry $1 \mathrm{~F}$ em Spodoptera frugiperda (Smith) (Lepdoptera: Noctuidae). Revista Brasileira de Milho e Sorgo, v. 3, n. 2, p. 161-171, 2004.

WARFIELD, C. Y.; DAVIS, R. M. Importance of the husk covering on the susceptibility of corn hybrids to Fusarium ear rot. Plant Disease, v. 80, p. 208-210, 1996. 
WAŚKIEWICZ, A, BESZTERDA, M, GOLIŃSKI, P. Occurrence of fumonisins in food - an interdisciplinary approach to the problem. Food Control, v. 26, p. 491-499, 2012.

ZAHA, A. Biologia molecular básica. Porto Alegre: Mercado Aberto, 1996. 336 p. 


\section{APÊNDICE A}

Figura A.1. Curvas de dissociação obtidas para os genes $F U M$, para a verificação da especificidade dos produtos de amplificação gerados pela reação de qPCR.

\section{a. FUM1}

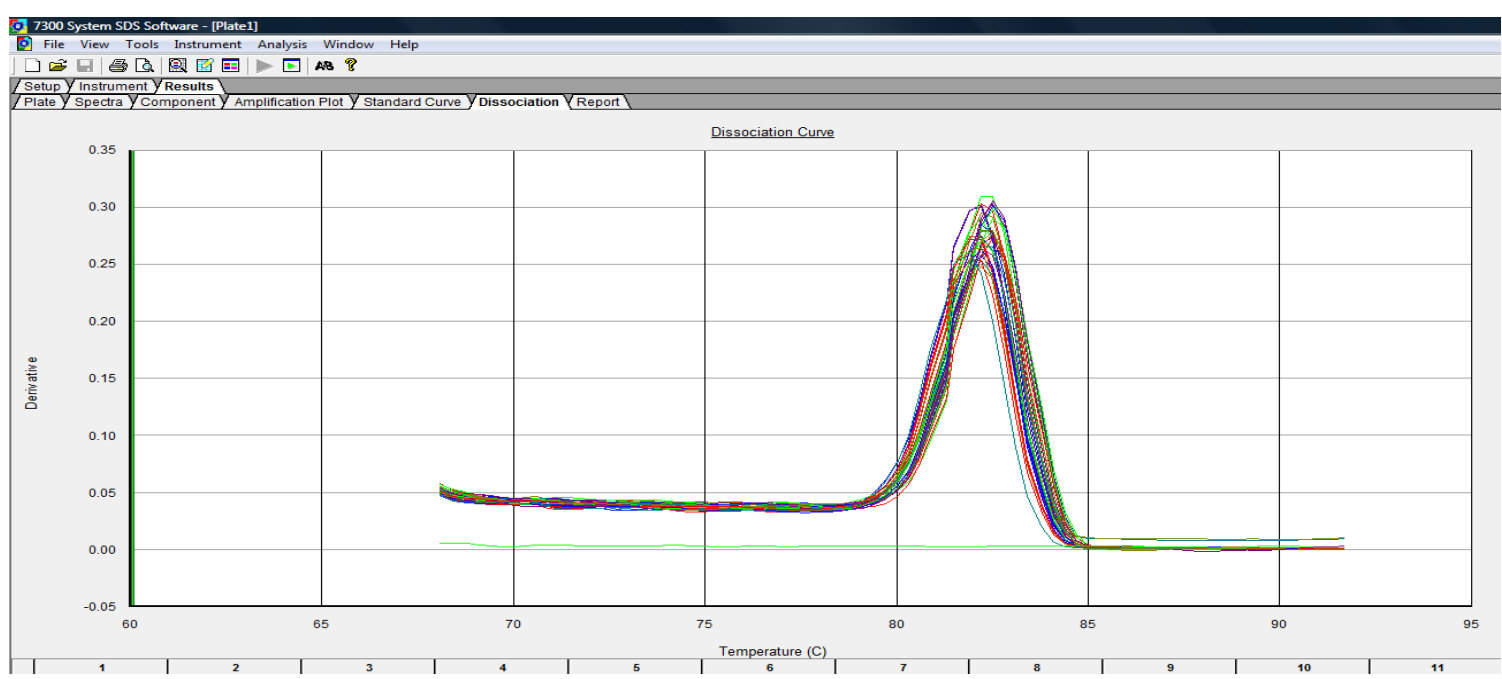

* Teste realizado no equipamento 7500 Real time PCR (Applied Biosystems) 
b. FUM2, FUM6, FUM7, FUM8 e FUM9
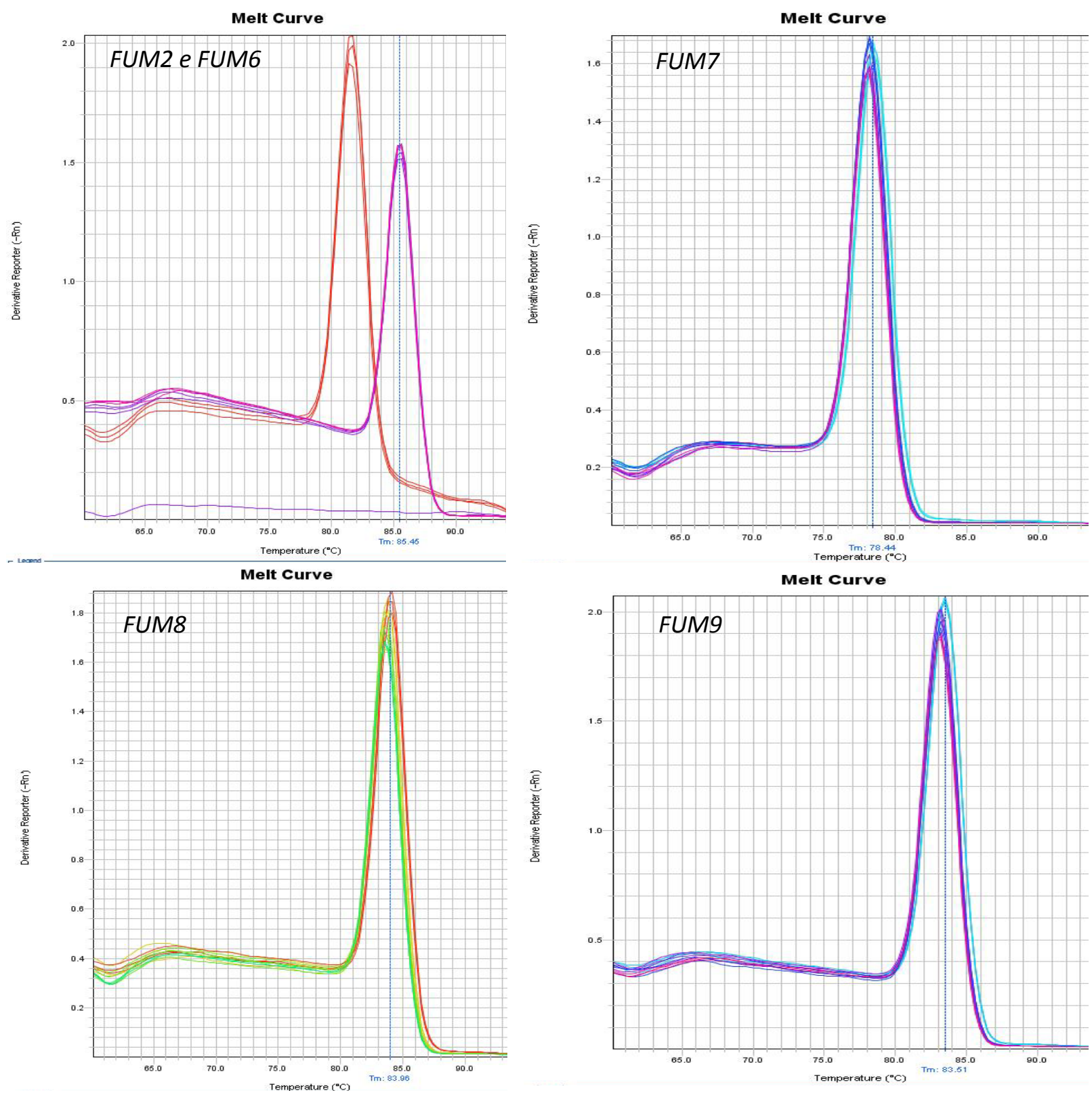
c. FUM10, FUM11, FUM13, FUM14
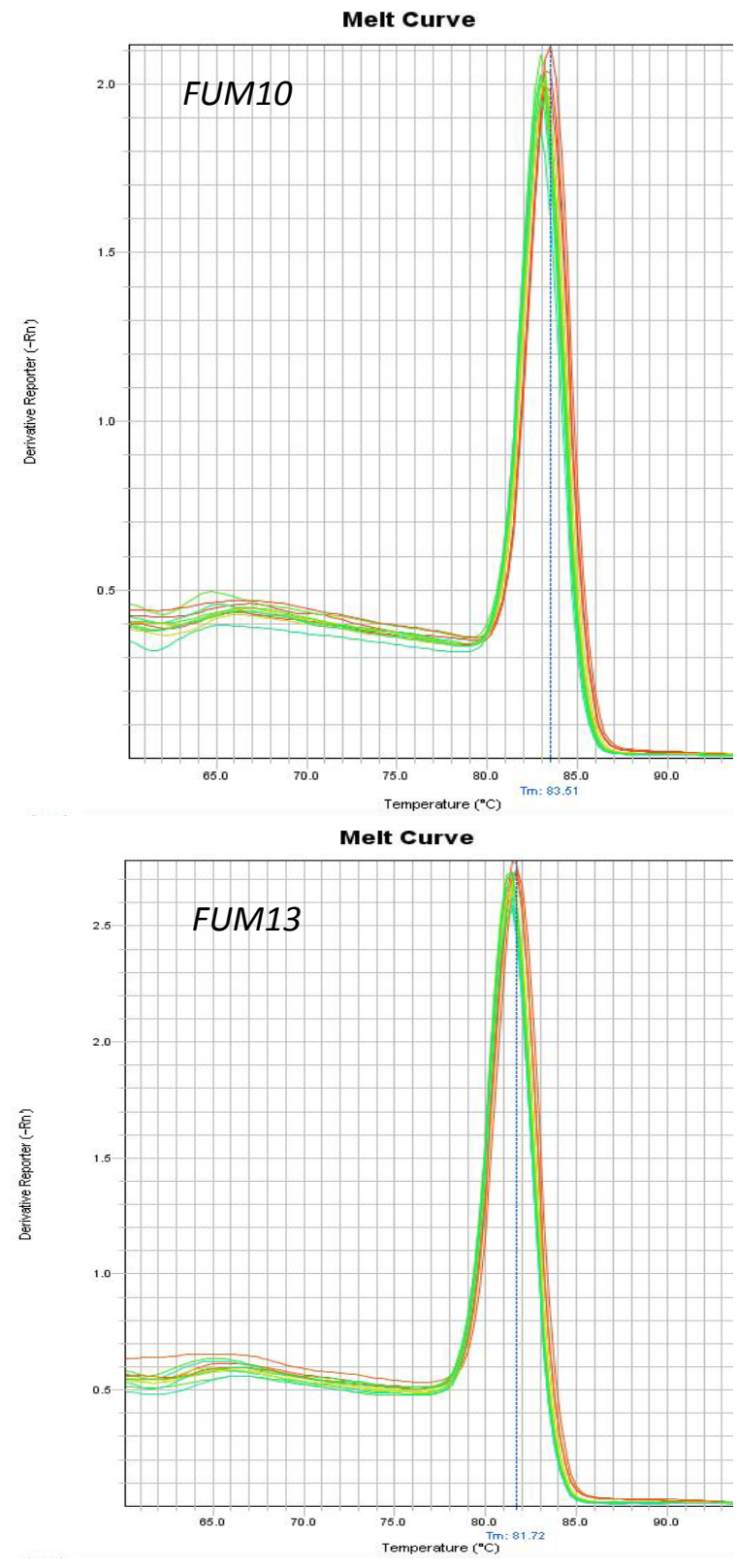
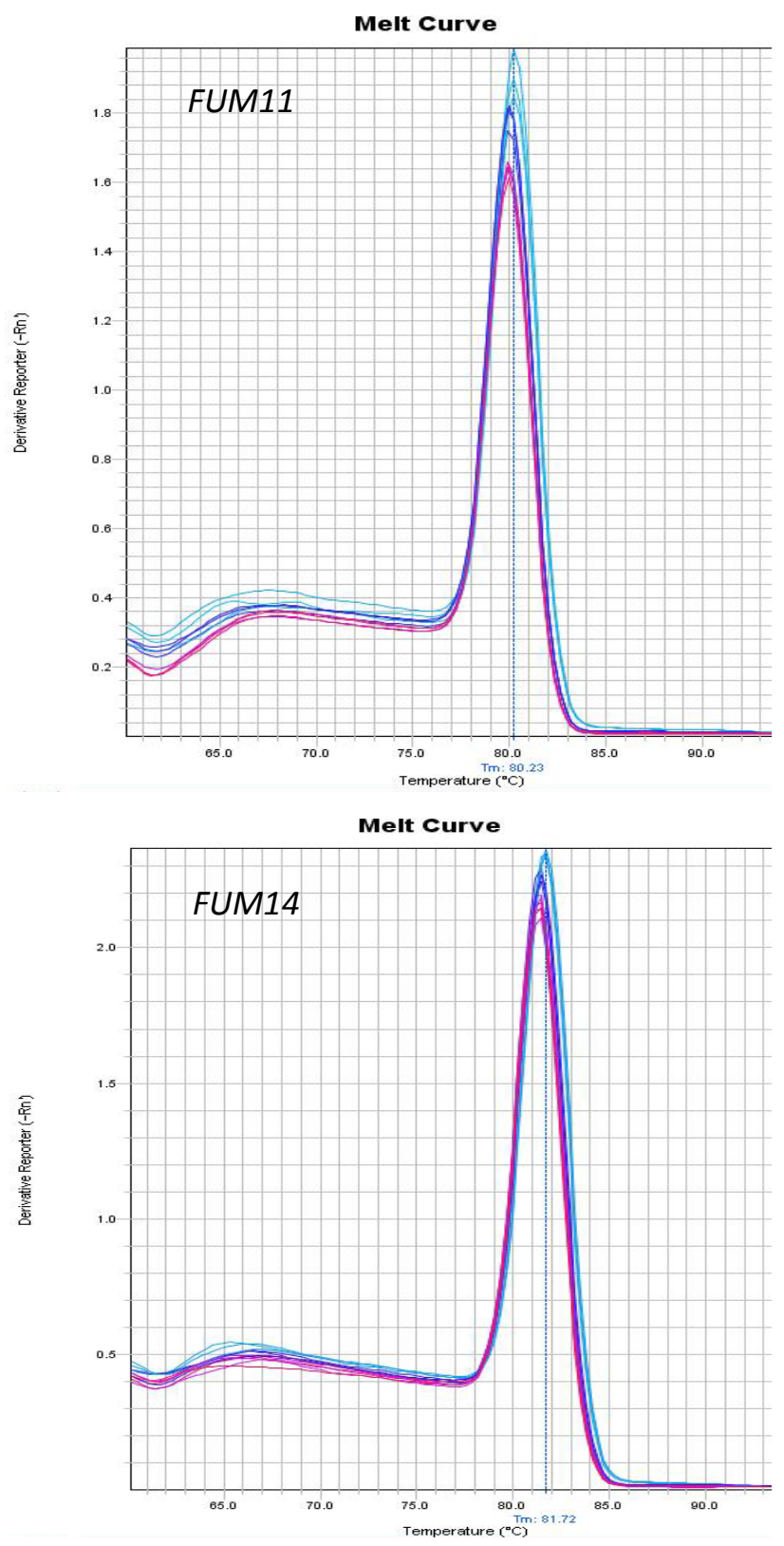
d. FIM15, FUM16, FUM17 e FUM18
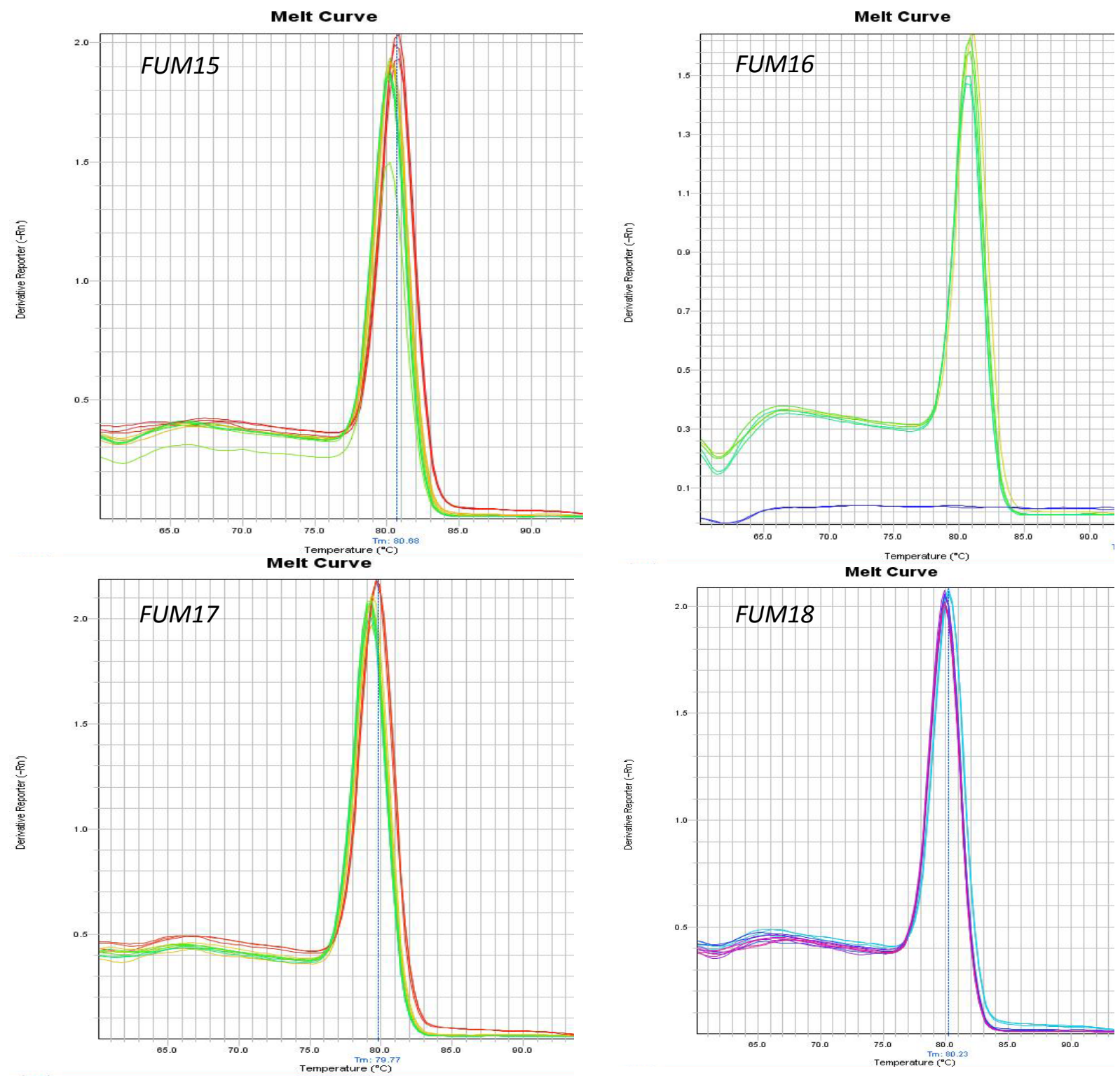
e. FUM19 e FUM21
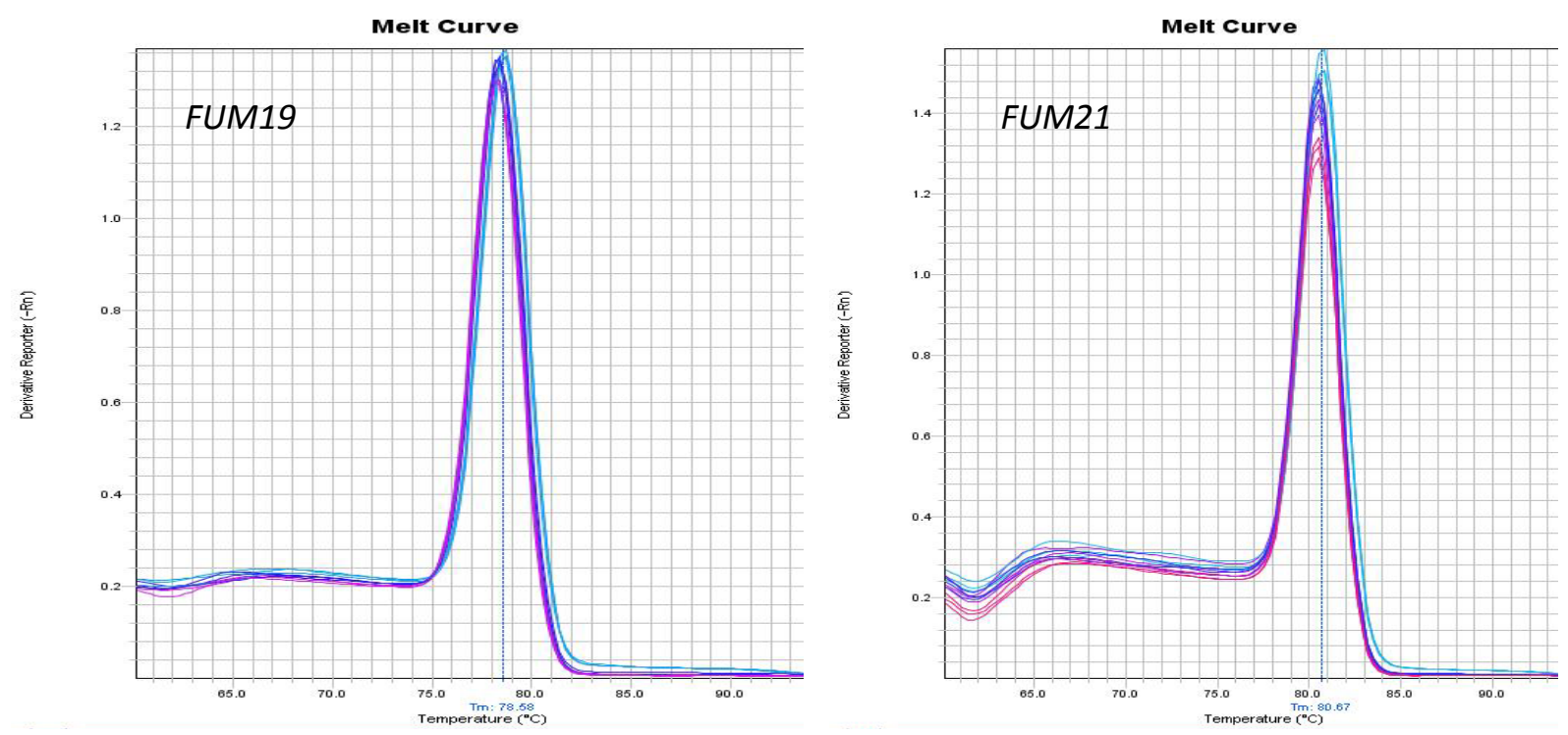

f. Tubulina $(T U B)$

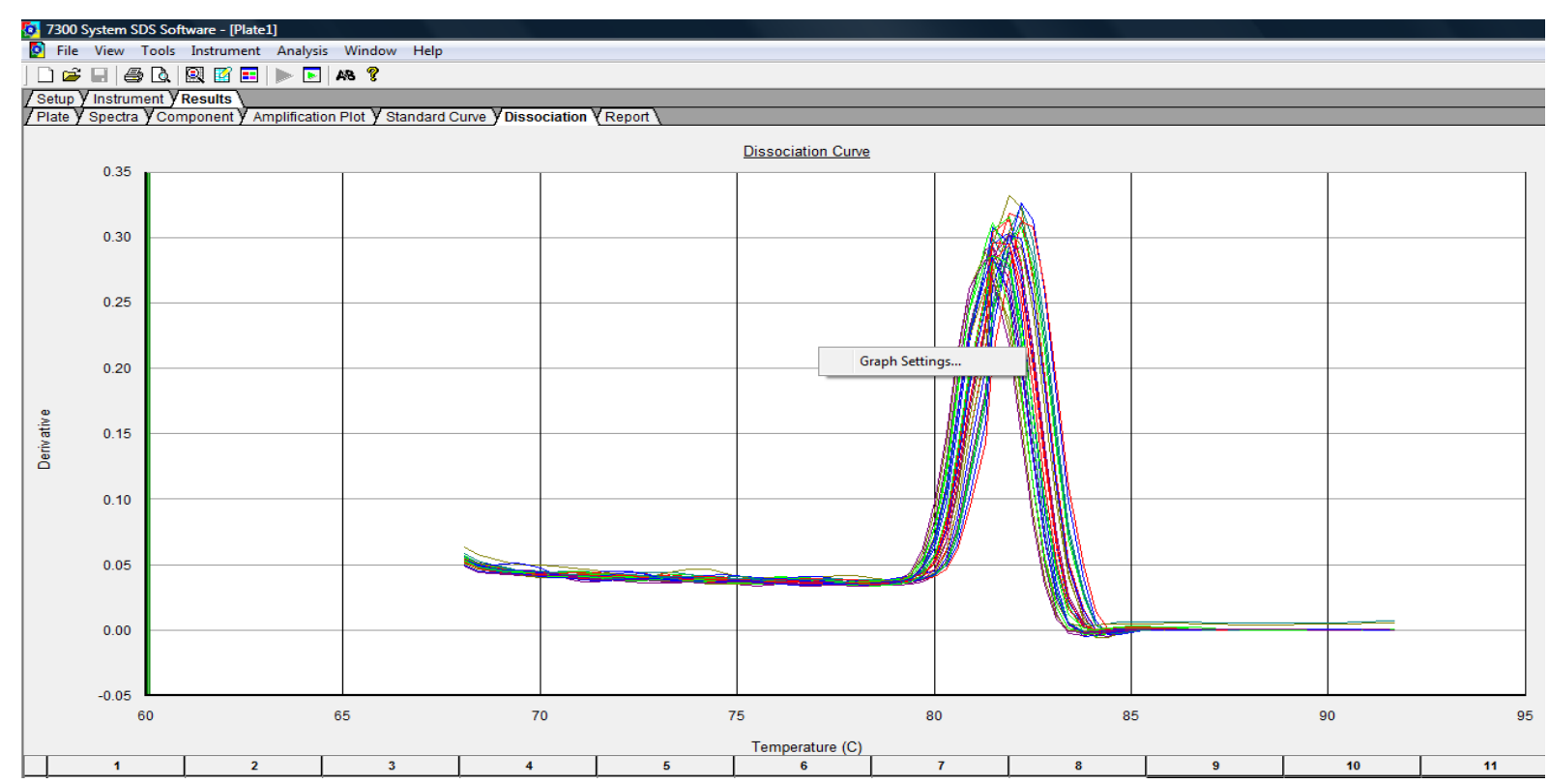

* Teste realizado no equipamento 7500 Real time PCR (Applied Biosystems)

Figura A.2. Cladograma não enraizado inferido utilizando-se a sequência parcial do gene do fator de elongação 1- $\alpha$ das cepas ioladas de grãos de milho das 7 coletas de estudo, pelo PAUP 4.0b10, baseado no método de distância com algoritmo neighbor-joining. A análise não paramétrica de bootstrap foi realizada para 100 réplicas, cujos valores em porcentagem, estão descritos nos ramos. Os números indicam os números das amostras e as coletas das quais as mesmas foram provenientes, a saber $\mathrm{C} 1$ (fase de florescimento), $\mathrm{C} 2$ (fase de grão leitoso), C3 (fase de grão pastoso), C4 (fase de grão farináceo), C5 (fase de grão farináceo-duro), C6 (fase de maturidade fisiológica) e C7 (colheita final). 


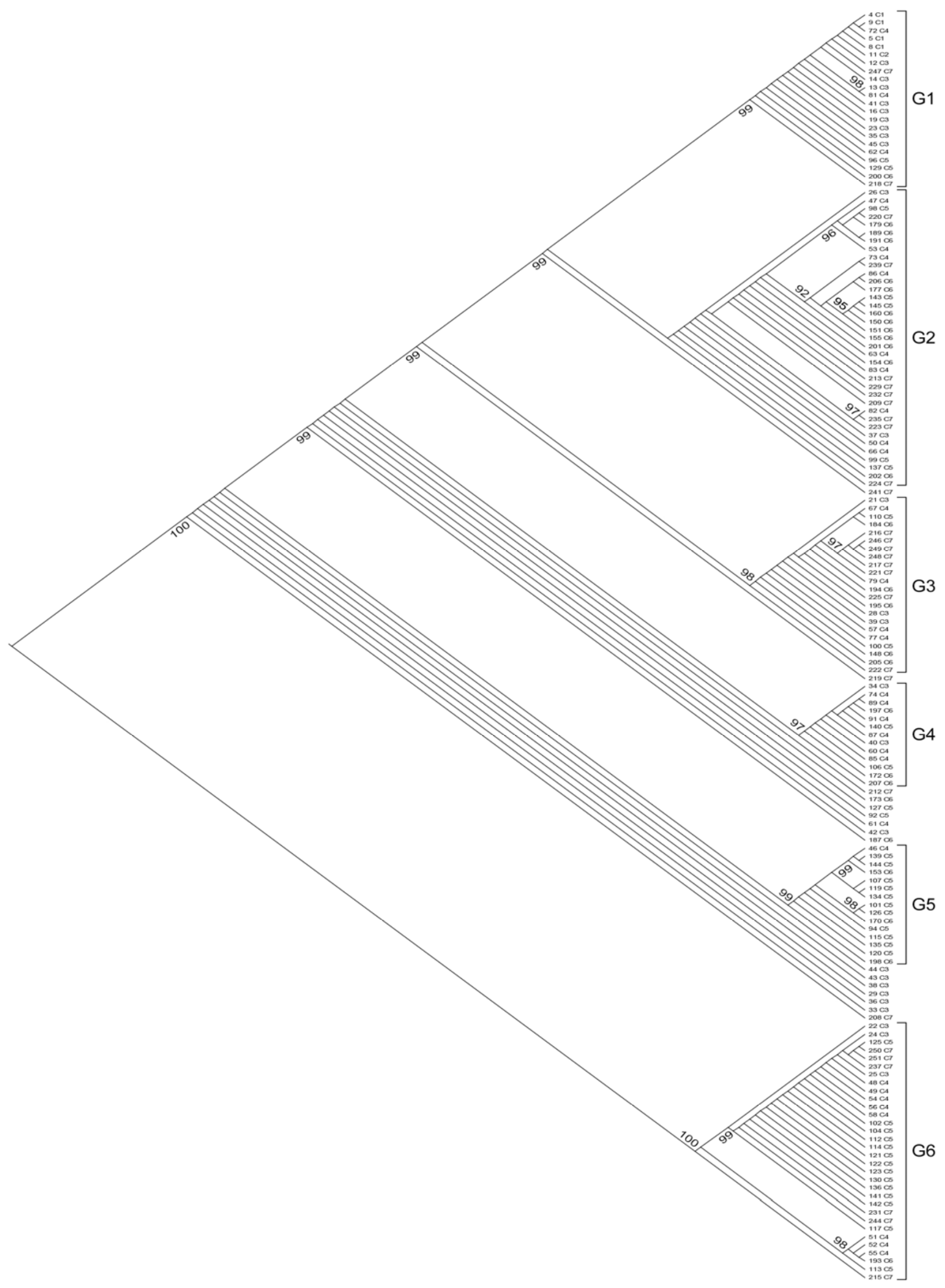


APÊNDICE B 


\begin{tabular}{|c|c|c|c|c|c|c|c|c|c|c|c|c|c|c|c|c|c|c|}
\hline \multicolumn{2}{|c|}{ Coleta $1^{*}$} & \multicolumn{17}{|c|}{ Tabela B. 1- Porcentagem de Contaminação Fúngica } \\
\hline Amostras & $\mathrm{Aa}$ & \begin{tabular}{|c|} 
Acremonium \\
spp.
\end{tabular} & $\begin{array}{l}\text { Rhizopus } \\
\text { spp. }\end{array}$ & FNE & Leveduras & $\begin{array}{c}\text { Penicilium } \\
\text { spp. }\end{array}$ & \begin{tabular}{|c|} 
Aspergillus \\
spp. \\
\end{tabular} & \begin{tabular}{|c|} 
Fusarium \\
verticillioides
\end{tabular} & $\begin{array}{c}\text { Fusarium } \\
\text { anthophilum }\end{array}$ & $\begin{array}{c}\text { Fusarium } \\
\text { subglutinans }\end{array}$ & $\begin{array}{l}\text { Geotrichum } \\
\text { spp. }\end{array}$ & $\begin{array}{c}\text { Curvularia } \\
\text { spp. }\end{array}$ & \begin{tabular}{c|} 
Trichoderma \\
spp.
\end{tabular} & $\begin{array}{c}\text { Cladosporium } \\
\text { spp. }\end{array}$ & $\begin{array}{c}\text { Nigrospora } \\
\text { spp. }\end{array}$ & $\begin{array}{c}\text { Neurospora } \\
\text { spp. }\end{array}$ & \begin{tabular}{|c|}
$\begin{array}{c}\text { Alternaria } \\
\text { spp. }\end{array}$ \\
\end{tabular} & $\begin{array}{c}\text { Mucor } \\
\text { spp. }\end{array}$ \\
\hline A1 & 0,99 & 9,09 & 9,09 & 9,09 & 97 & 0 & 0 & 0 & 0 & 0 & 0 & 0 & 0 & 0 & 0 & 0 & 0 & 0 \\
\hline $\mathrm{A} 2$ & 0,99 & 0 & 0 & 0 & 63,64 & 3,03 & 9,09 & 0 & 0 & 21,21 & 0 & 0 & 0 & 0 & 0 & 0 & 0 & 0 \\
\hline $\mathrm{A} 3$ & 0,99 & 0 & 0 & 0 & 69,7 & 6,06 & 0 & 0 & 0 & 0 & 9,09 & 0 & 0 & 0 & 0 & 0 & 0 & 0 \\
\hline A4 & 0,99 & 0 & 21,21 & 0 & 66,7 & 3,03 & 0 & 0 & 0 & 0 & 0 & 12,12 & 0 & 0 & 0 & 0 & 0 & 0 \\
\hline A5 & 0,99 & 9,09 & 0 & 0 & 81,82 & 0 & 6,06 & 0 & 0 & 0 & 0 & 0 & 0 & 0 & 0 & 0 & 0 & 0 \\
\hline A6 & 0,99 & 3,03 & 0 & 15,15 & 75,76 & 9,09 & 0 & 0 & 0 & 0 & 0 & 0 & 0 & 0 & 0 & 0 & 0 & 0 \\
\hline A7 & 0,99 & 0 & 0 & 0 & 100 & 0 & 0 & 0 & 0 & 0 & 0 & 0 & 3,03 & 0 & 0 & 0 & 0 & 0 \\
\hline $\mathrm{A} 8$ & 0,99 & 0 & 0 & 0 & 81,82 & 6,06 & 0 & 0 & 0 & 21,21 & 0 & 0 & 0 & 0 & 0 & 0 & 0 & 0 \\
\hline A9 & 0,99 & 0 & 0 & 6,06 & 100 & 0 & 0 & 0 & 0 & 0 & 0 & 0 & 0 & 0 & 0 & 0 & 0 & 0 \\
\hline A10 & 0,99 & 0 & 15,15 & 0 & 100 & 3,03 & 0 & 9,09 & 0 & 0 & 0 & 0 & 0 & 3,03 & 0 & 0 & 0 & 0 \\
\hline A11 & 0,99 & 0 & 0 & 0 & 72,73 & 0 & 3,03 & 0 & 0 & 0 & 21,21 & 0 & 0 & 0 & 0 & 0 & 0 & 0 \\
\hline $\mathrm{A} 12$ & 0,99 & 0 & 0 & 0 & 87,88 & 6,06 & 0 & 0 & 0 & 0 & 3,03 & 0 & 0 & 3,03 & 21,21 & 0 & 0 & 0 \\
\hline $\mathrm{A} 13$ & 0,99 & 0 & 0 & 0 & 87,88 & 6,06 & 9,09 & 0 & 0 & 0 & 6,06 & 0 & 0 & 0 & 0 & 0 & 0 & 0 \\
\hline A14 & 0,99 & 0 & 0 & 0 & 27,27 & 9,09 & 0 & 0 & 15,15 & 0 & 0 & 0 & 0 & 0 & 0 & 0 & 0 & 0 \\
\hline A15 & 0,99 & 0 & 18,18 & 0 & 9,09 & 15,15 & 0 & 0 & 0 & 0 & 3,03 & 0 & 0 & 0 & 0 & 0 & 0 & 0 \\
\hline A16 & 0,99 & 15,15 & 0 & 3,03 & 60,61 & 0 & 0 & 0 & 0 & 0 & 3,03 & 0 & 0 & 0 & 0 & 0 & 0 & 0 \\
\hline A17 & 0,99 & 0 & 0 & 0 & 51,52 & 0 & 0 & 0 & 0 & 0 & 0 & 0 & 0 & 0 & 0 & 0 & 0 & 0 \\
\hline A18 & 0,99 & 0 & 0 & 3,03 & 45,46 & 3,03 & 0 & 6,06 & 0 & 0 & 0 & 0 & 0 & 0 & 0 & 0 & 0 & 0 \\
\hline A19 & 0,99 & 0 & 0 & 0 & 87,88 & 15,15 & 0 & 0 & 0 & 0 & 0 & 0 & 0 & 0 & 0 & 0 & 3,03 & 0 \\
\hline A20 & 0,99 & 0 & 0 & 0 & 30,3 & 9,09 & 0 & 0 & 0 & 0 & 0 & 0 & 0 & 0 & 0 & 0 & 0 & 0 \\
\hline A21 & 0,99 & 0 & 0 & 3,03 & 45,46 & 0 & 0 & 0 & 0 & 0 & 0 & 0 & 0 & 0 & 0 & 6,06 & 0 & 0 \\
\hline A22 & 0,99 & 0 & 0 & 0 & 54,55 & 0 & 0 & 0 & 0 & 0 & 0 & 0 & 0 & 0 & 0 & 0 & 0 & 0 \\
\hline A23 & 0,99 & 0 & 0 & 0 & 27,27 & 0 & 0 & 0 & 0 & 0 & 0 & 0 & 0 & 0 & 0 & 0 & 0 & 0 \\
\hline A24 & 0,99 & 0 & 0 & 12,12 & 12,12 & 12,12 & 0 & 0 & 0 & 0 & 0 & 0 & 0 & 0 & 0 & 0 & 0 & 0 \\
\hline A25 & 0,99 & 0 & 0 & 0 & 33,33 & 9,09 & 0 & 0 & 0 & 0 & 18,18 & 0 & 0 & 0 & 0 & 0 & 0 & 0 \\
\hline A26 & 0,99 & 0 & 0 & 0 & 42,42 & 3,03 & 0 & 0 & 0 & 0 & 0 & 0 & 0 & 0 & 0 & 3,03 & 0 & 0 \\
\hline A27 & 0,99 & 0 & 0 & 0 & 100 & 9,09 & 0 & 0 & 0 & 0 & 0 & 0 & 3,03 & 0 & 0 & 0 & 0 & 0 \\
\hline A28 & 0,99 & 0 & 0 & 6,06 & 69,7 & 0 & 0 & 0 & 0 & 0 & 0 & 0 & 0 & 0 & 0 & 0 & 0 & 0 \\
\hline A29 & 0,99 & 0 & 0 & 0 & 93,94 & 0 & 0 & 0 & 0 & 0 & 0 & 0 & 0 & 0 & 3,03 & 0 & 0 & 3,03 \\
\hline
\end{tabular}




\begin{tabular}{|c|c|c|c|c|c|c|c|c|c|c|c|c|c|c|c|c|c|c|}
\hline \multicolumn{2}{|c|}{ Coleta $1 *$} & \multicolumn{17}{|c|}{ Continuação -Tabela B.1- Porcentagem Contaminação Fúngica } \\
\hline Amostras & $\mathrm{Aa}$ & $\begin{array}{c}\text { Acremonium } \\
\text { spp. }\end{array}$ & $\begin{array}{c}\text { Rhizopus } \\
\text { spp. }\end{array}$ & FNE & Leveduras & \begin{tabular}{c|} 
Penicilium \\
spp.
\end{tabular} & \begin{tabular}{|c|} 
Aspergillus \\
spp.
\end{tabular} & $\begin{array}{c}\text { Fusarium } \\
\text { verticillioides }\end{array}$ & $\begin{array}{c}\text { Fusarium } \\
\text { anthophilum }\end{array}$ & \begin{tabular}{c|c}
$\begin{array}{c}\text { Fusarium } \\
\text { subglutinans }\end{array}$ \\
\end{tabular} & $\begin{array}{c}\text { Geotrichum } \\
\text { spp. }\end{array}$ & \begin{tabular}{c|}
$\begin{array}{c}\text { Curvularia } \\
\text { spp. }\end{array}$ \\
\end{tabular} & $\begin{array}{c}\text { Trichoderma } \\
\text { spp. }\end{array}$ & $\begin{array}{c}\text { Cladosporium } \\
\text { spp. }\end{array}$ & $\begin{array}{c}\text { Nigrospora } \\
\text { spp. }\end{array}$ & $\begin{array}{c}\text { Neurospora } \\
\text { spp. }\end{array}$ & \begin{tabular}{|c|}
$\begin{array}{c}\text { Alternaria } \\
\text { spp. }\end{array}$ \\
\end{tabular} & $\begin{array}{l}\text { Mucor } \\
\text { spp. }\end{array}$ \\
\hline A30 & 0,99 & 6,06 & 0 & 3,03 & 100 & 0 & 0 & 0 & 0 & 0 & 0 & 0 & 0 & 0 & 0 & 0 & 0 & 0 \\
\hline A31 & 0,99 & 0 & 0 & 3,03 & 93,94 & 0 & 0 & 0 & 0 & 0 & 0 & 0 & 0 & 0 & 0 & 0 & 0 & 0 \\
\hline A32 & 0,99 & 0 & 0 & 0 & 81,82 & 0 & 3,03 & 0 & 0 & 0 & 0 & 0 & 0 & 3,03 & 0 & 0 & 0 & 0 \\
\hline A33 & 0,99 & 0 & 0 & 3,03 & 97 & 3,03 & 0 & 0 & 0 & 0 & 6,06 & 0 & 0 & 3,03 & 0 & 0 & 0 & 0 \\
\hline A34 & 0,99 & 0 & 0 & 12,12 & 48,49 & 0 & 0 & 0 & 0 & 0 & 0 & 0 & 0 & 3,03 & 0 & 0 & 0 & 0 \\
\hline A35 & 0,99 & 0 & 0 & 3,03 & 84,85 & 3,03 & 3,03 & 0 & 0 & 0 & 0 & 0 & 0 & 0 & 0 & 0 & 0 & 0 \\
\hline A36 & 0,99 & 0 & 0 & 0 & 100 & 0 & 0 & 0 & 0 & 0 & 15,15 & 0 & 0 & 0 & 0 & 3,03 & 0 & 0 \\
\hline A37 & 0,99 & 0 & 0 & 0 & 100 & 0 & 0 & 0 & 0 & 0 & 3,03 & 0 & 0 & 3,03 & 0 & 0 & 0 & 0 \\
\hline A38 & 0,99 & 0 & 0 & 0 & 100 & 0 & 0 & 0 & 0 & 0 & 0 & 0 & 0 & 6,06 & 0 & 0 & 0 & 0 \\
\hline A39 & 0,99 & 0 & 0 & 0 & 90,91 & 12,12 & 0 & 0 & 0 & 0 & 0 & 0 & 0 & 0 & 0 & 9,09 & 0 & 0 \\
\hline A40 & 0,99 & 0 & 0 & 6,06 & 100 & 0 & 0 & 0 & 0 & 0 & 0 & 0 & 0 & 0 & 0 & 6,06 & 0 & 0 \\
\hline A41 & 0,99 & 0 & 0 & 3,03 & 97 & 6,06 & 0 & 0 & 0 & 0 & 3,03 & 0 & 0 & 0 & 0 & 0 & 0 & 0 \\
\hline A42 & 0,99 & 0 & 0 & 0 & 100 & 3,03 & 0 & 0 & 0 & 0 & 0 & 0 & 0 & 3,03 & 0 & 9,09 & 0 & 3,03 \\
\hline A43 & 0,99 & 0 & 0 & 0 & 93,94 & 3,03 & 0 & 0 & 0 & 0 & 15,15 & 0 & 0 & 3,03 & 0 & 0 & 0 & 0 \\
\hline A44 & 0,99 & 0 & 0 & 0 & 93,94 & 0 & 0 & 0 & 0 & 0 & 9,09 & 0 & 0 & 0 & 0 & 0 & 0 & 0 \\
\hline A45 & 0,99 & 0 & 0 & 3,03 & 84,85 & 0 & 3,03 & 0 & 0 & 0 & 0 & 0 & 0 & 0 & 0 & 0 & 0 & 0 \\
\hline A46 & 0,99 & 0 & 0 & 0 & 100 & 6,06 & 0 & 0 & 0 & 0 & 6,06 & 0 & 0 & 3,03 & 0 & 0 & 0 & 6,06 \\
\hline A47 & 0,99 & 0 & 0 & 0 & 97 & 6,06 & 0 & 12,12 & 0 & 0 & 0 & 0 & 0 & 0 & 0 & 0 & 0 & 0 \\
\hline A48 & 0,99 & 0 & 6,06 & 15,15 & 100 & 0 & 0 & 0 & 0 & 0 & 0 & 0 & 0 & 0 & 0 & 0 & 0 & 0 \\
\hline A49 & 0,99 & 0 & 0 & 0 & 97 & 0 & 0 & 9,09 & 0 & 0 & 0 & 0 & 0 & 0 & 0 & 0 & 0 & 3,03 \\
\hline A50 & 0,99 & 0 & 0 & 0 & 97 & 6,06 & 0 & 0 & 0 & 0 & 24,24 & 0 & 0 & 0 & 0 & 0 & 0 & 0 \\
\hline A51 & 0,99 & 0 & 0 & 15,15 & 100 & 15,15 & 0 & 0 & 0 & 0 & 0 & 0 & 0 & 3,03 & 0 & 0 & 0 & 0 \\
\hline A52 & 0,99 & 0 & 0 & 0 & 100 & 12,12 & 0 & 18,18 & 0 & 0 & 0 & 0 & 0 & 9,09 & 0 & 0 & 0 & 0 \\
\hline Média & 0,99 & 0,82 & 1,34 & 2,39 & 77,56 & 3,9 & 0,7 & 1,05 & 0,29 & 0,82 & 2,8 & 0,23 & 0,12 & 0,87 & 0,47 & 0,7 & 0,06 & 0,29 \\
\hline $\begin{array}{l}\text { Desvio } \\
\text { Padrão }\end{array}$ & 0 & 2,82 & 4,51 & 4,34 & 26,33 & 4,7 & 2,05 & 3,49 & 2,01 & 4,12 & 5,84 & 1,68 & 0,59 & 1,83 & 2,96 & 2,13 & 0,42 & 1,08 \\
\hline
\end{tabular}




\begin{tabular}{|c|c|c|c|c|c|c|c|c|c|c|c|c|c|c|c|c|c|}
\hline \multicolumn{2}{|c|}{ Coleta $2^{*}$} & \multicolumn{16}{|c|}{ Tabela B. 2- Porcentagem Contaminação Fúngica } \\
\hline Amostras & $\mathrm{Aa}$ & $\begin{array}{c}\text { Acremonium } \\
\text { spp. }\end{array}$ & \begin{tabular}{|c|} 
Rhizopus \\
spp.
\end{tabular} & FNE & Levedura & \begin{tabular}{c|} 
Penicillium \\
spp.
\end{tabular} & $\begin{array}{c}\text { Aspergillus } \\
\text { spp. }\end{array}$ & $\begin{array}{c}\text { Fusarium } \\
\text { verticillioides }\end{array}$ & $\begin{array}{c}\text { Fusarium } \\
\text { anthophilum }\end{array}$ & $\begin{array}{c}\text { Geotrichum } \\
\text { spp. }\end{array}$ & $\begin{array}{c}\text { Curvularia } \\
\text { spp. }\end{array}$ & $\begin{array}{c}\text { Trichoderma } \\
\text { spp. }\end{array}$ & $\begin{array}{c}\text { Cladosporium } \\
\text { spp. }\end{array}$ & $\begin{array}{c}\text { Nigrospora } \\
\text { spp. }\end{array}$ & \begin{tabular}{|c|} 
Neurospora \\
spp.
\end{tabular} & $\begin{array}{c}\text { Alternaria } \\
\text { spp. }\end{array}$ & $\begin{array}{l}\text { Mucor } \\
\text { spp. }\end{array}$ \\
\hline A1 & 0,98 & 0 & 6,06 & 0 & 100 & 3,03 & 0 & 0 & 0 & 9,09 & 0 & 0 & 3,03 & 0 & 0 & 3,03 & 0 \\
\hline $\mathrm{A} 2$ & 0,98 & 0 & 0 & 6,06 & 96,97 & 3,03 & 3,03 & 0 & 0 & 9,09 & 0 & 0 & 0 & 0 & 0 & 0 & 0 \\
\hline $\mathrm{A} 3$ & 0,98 & 0 & 9,09 & 0 & 100 & 0 & 3,03 & 0 & 12,12 & 3,03 & 0 & 0 & 0 & 0 & 0 & 0 & 0 \\
\hline A4 & 0,98 & 0 & 27,27 & 9,09 & 100 & 0 & 0 & 0 & 0 & 0 & 0 & 0 & 0 & 0 & 0 & 0 & 0 \\
\hline A5 & 0,98 & 0 & 0 & 0 & 96,97 & 12,12 & 9,09 & 0 & 0 & 3,03 & 0 & 0 & 0 & 0 & 0 & 0 & 0 \\
\hline A6 & 0,99 & 0 & 0 & 0 & 69,7 & 0 & 0 & 0 & 0 & 0 & 0 & 0 & 0 & 0 & 0 & 0 & 0 \\
\hline A7 & 0,99 & 0 & 0 & 0 & 87,88 & 0 & 0 & 0 & 0 & 6,06 & 0 & 0 & 0 & 0 & 0 & 0 & 3,03 \\
\hline $\mathrm{A} 8$ & 0,99 & 0 & 3,03 & 0 & 87,88 & 3,03 & 0 & 0 & 0 & 0 & 0 & 0 & 0 & 0 & 0 & 12,12 & 0 \\
\hline A9 & 0,98 & 0 & 0 & 0 & 87,88 & 0 & 0 & 0 & 0 & 30,3 & 0 & 3,03 & 0 & 0 & 0 & 0 & 0 \\
\hline A10 & 0,99 & 0 & 3,03 & 9,09 & 75,76 & 3,03 & 0 & 0 & 0 & 6,06 & 0 & 0 & 0 & 0 & 0 & 0 & 0 \\
\hline A11 & 0,98 & 0 & 0 & 0 & 81,82 & 0 & 0 & 0 & 0 & 3,03 & 0 & 0 & 0 & 0 & 0 & 0 & 12,12 \\
\hline $\mathrm{A} 12$ & 0,99 & 0 & 3,03 & 12,12 & 96,97 & 3,03 & 0 & 0 & 0 & 3,03 & 0 & 0 & 3,03 & 0 & 0 & 3,03 & 0 \\
\hline A13 & 0,99 & 0 & 3,03 & 12,12 & 100 & 0 & 0 & 0 & 0 & 3,03 & 0 & 0 & 6,06 & 0 & 0 & 0 & 0 \\
\hline A14 & 0,98 & 0 & 0 & 6,06 & 69,7 & 0 & 0 & 0 & 0 & 0 & 0 & 0 & 0 & 0 & 6,06 & 0 & 0 \\
\hline A15 & 0,99 & 0 & 0 & 0 & 84,85 & 0 & 12,12 & 0 & 0 & 15,15 & 0 & 0 & 0 & 0 & 0 & 0 & 0 \\
\hline A16 & 0,98 & 0 & 0 & 0 & 100 & 0 & 0 & 0 & 0 & 9,09 & 0 & 0 & 0 & 3,03 & 0 & 0 & 0 \\
\hline A17 & 0,98 & 0 & 0 & 0 & 84,85 & 0 & 6,06 & 0 & 0 & 3,03 & 0 & 0 & 0 & 0 & 0 & 0 & 0 \\
\hline A18 & 0,98 & 0 & 0 & 0 & 75,76 & 0 & 3,03 & 12,12 & 0 & 0 & 0 & 0 & 0 & 0 & 0 & 0 & 0 \\
\hline A19 & 0,99 & 0 & 0 & 0 & 69,7 & 0 & 15,15 & 0 & 0 & 9,09 & 0 & 0 & 3,03 & 0 & 0 & 0 & 0 \\
\hline $\mathrm{A} 20$ & 0,98 & 0 & 0 & 0 & 100 & 0 & 9,09 & 0 & 0 & 0 & 0 & 0 & 0 & 0 & 0 & 0 & 6,06 \\
\hline A21 & 0,98 & 0 & 0 & 0 & 66,67 & 0 & 3,03 & 0 & 0 & 9,09 & 0 & 0 & 0 & 0 & 0 & 0 & 0 \\
\hline $\mathrm{A} 22$ & 0,99 & 0 & 3,03 & 0 & 100 & 0 & 0 & 0 & 0 & 3,03 & 0 & 0 & 3,03 & 0 & 0 & 3,03 & 0 \\
\hline A23 & 0,98 & 0 & 66,67 & 3,03 & 96,97 & 3,03 & 0 & 0 & 0 & 12,12 & 0 & 0 & 0 & 0 & 0 & 0 & 3,03 \\
\hline A24 & 0,98 & 0 & 0 & 3,03 & 39,39 & 0 & 0 & 0 & 0 & 9,09 & 0 & 0 & 0 & 0 & 0 & 0 & 0 \\
\hline A25 & 0,98 & 0 & 0 & 0 & 63,64 & 0 & 0 & 0 & 0 & 6,06 & 0 & 0 & 3,03 & 0 & 0 & 0 & 12,12 \\
\hline A26 & 0,99 & 0 & 0 & 9,09 & 100 & 3,03 & 0 & 0 & 0 & 27,27 & 0 & 6,06 & 3,03 & 0 & 0 & 0 & 0 \\
\hline A28 & 0,99 & 0 & 6,06 & 0 & 24,24 & 0 & 0 & 0 & 0 & 6,06 & 0 & 0 & 0 & 0 & 0 & 0 & 0 \\
\hline
\end{tabular}




\begin{tabular}{|c|c|c|c|c|c|c|c|c|c|c|c|c|c|c|c|c|c|}
\hline \multicolumn{2}{|c|}{ Coleta $2^{*}$} & \multicolumn{16}{|c|}{ Continuação - Tabela B.2- Porcentagem Contaminação Fúngica } \\
\hline Amostras & $\mathrm{Aa}$ & $\begin{array}{c}\text { Acremonium } \\
\text { spp. }\end{array}$ & $\begin{array}{c}\begin{array}{c}\text { Rhizopus } \\
\text { spp. }\end{array} \\
\end{array}$ & FNE & Levedura & \begin{tabular}{|c} 
Penicillium \\
spp.
\end{tabular} & $\begin{array}{l}\text { Aspergillus } \\
\text { spp. }\end{array}$ & $\begin{array}{c}\text { Fusarium } \\
\text { verticillioides }\end{array}$ & $\begin{array}{c}\text { Fusarium } \\
\text { anthophilum }\end{array}$ & $\begin{array}{c}\text { Geotrichum } \\
\text { spp. }\end{array}$ & $\begin{array}{c}\text { Curvularia } \\
\text { spp. }\end{array}$ & $\begin{array}{c}\text { Trichoderma } \\
\text { spp. }\end{array}$ & $\begin{array}{c}\text { Cladosporium } \\
\text { spp. }\end{array}$ & $\begin{array}{c}\text { Nigrospora } \\
\text { spp. }\end{array}$ & $\begin{array}{c}\text { Neurospora } \\
\text { spp. }\end{array}$ & $\begin{array}{c}\text { Alternaria } \\
\text { spp. }\end{array}$ & $\begin{array}{c}\text { Mucor } \\
\text { spp. }\end{array}$ \\
\hline A29 & 0,98 & 0 & 0 & 0 & 42,42 & 3,03 & 0 & 0 & 0 & 12,12 & 0 & 0 & 0 & 0 & 12,12 & 0 & 0 \\
\hline A30 & 0,99 & 0 & 0 & 0 & 66,67 & 0 & 0 & 0 & 0 & 6,06 & 0 & 0 & 0 & 0 & 0 & 0 & 3,03 \\
\hline A31 & 0,99 & 0 & 0 & 0 & 27,27 & 0 & 0 & 0 & 0 & 6,06 & 3,03 & 0 & 0 & 0 & 0 & 0 & 0 \\
\hline A32 & 0,99 & 0 & 0 & 0 & 39,39 & 0 & 0 & 0 & 0 & 21,21 & 0 & 0 & 0 & 0 & 0 & 0 & 0 \\
\hline A33 & 0,98 & 0 & 0 & 0 & 24,24 & 0 & 3,03 & 0 & 0 & 27,27 & 0 & 0 & 0 & 0 & 0 & 0 & 0 \\
\hline A34 & 0,99 & 0 & 0 & 12,12 & 66,67 & 0 & 0 & 0 & 0 & 3,03 & 0 & 0 & 0 & 0 & 3,03 & 0 & 0 \\
\hline A35 & 0,98 & 0 & 0 & 0 & 45,46 & 0 & 0 & 0 & 0 & 0 & 0 & 0 & 0 & 0 & 0 & 0 & 6,06 \\
\hline A36 & 0,98 & 3,03 & 0 & 0 & 30,3 & 0 & 0 & 0 & 0 & 9,09 & 0 & 0 & 0 & 0 & 0 & 6,06 & 0 \\
\hline A37 & 0,98 & 0 & 0 & 0 & 48,49 & 3,03 & 0 & 0 & 0 & 6,06 & 0 & 0 & 0 & 0 & 0 & 0 & 0 \\
\hline A38 & 0,98 & 0 & 0 & 3,03 & 84,85 & 0 & 0 & 0 & 0 & 0 & 0 & 0 & 0 & 0 & 0 & 0 & 0 \\
\hline A39 & 0,99 & 0 & 9,09 & 0 & 81,82 & 3,03 & 0 & 0 & 0 & 3,03 & 0 & 0 & 0 & 0 & 0 & 0 & 3,03 \\
\hline $\mathrm{A} 40$ & 0,98 & 0 & 0 & 0 & 63,64 & 0 & 0 & 0 & 0 & 9,09 & 0 & 0 & 3,03 & 0 & 0 & 0 & 9,09 \\
\hline A41 & 0,98 & 0 & 3,03 & 18,18 & 66,67 & 0 & 3,03 & 0 & 0 & 0 & 0 & 0 & 0 & 0 & 0 & 0 & 0 \\
\hline $\mathrm{A} 42$ & 0,99 & 0 & 0 & 12,12 & 96,97 & 12,12 & 0 & 0 & 0 & 6,06 & 0 & 0 & 0 & 0 & 0 & 0 & 0 \\
\hline $\mathrm{A} 43$ & 0,99 & 0 & 0 & 0 & 63,64 & 6,06 & 0 & 0 & 0 & 3,03 & 0 & 3,03 & 0 & 0 & 0 & 0 & 0 \\
\hline A44 & 0,98 & 0 & 0 & 0 & 100 & 0 & 0 & 0 & 0 & 18,18 & 0 & 0 & 0 & 0 & 0 & 0 & 0 \\
\hline A45 & 0,99 & 0 & 0 & 0 & 100 & 0 & 0 & 0 & 0 & 18,18 & 0 & 0 & 0 & 0 & 0 & 0 & 0 \\
\hline A46 & 0,99 & 0 & 0 & 6,06 & 75,76 & 0 & 0 & 0 & 0 & 3,03 & 0 & 0 & 0 & 0 & 0 & 0 & 0 \\
\hline A47 & 0,98 & 0 & 0 & 0 & 75,76 & 0 & 0 & 0 & 0 & 24,24 & 0 & 0 & 0 & 0 & 0 & 0 & 0 \\
\hline $\mathrm{A} 48$ & 0,98 & 0 & 0 & 0 & 69,7 & 3,03 & 0 & 0 & 0 & 6,06 & 0 & 0 & 0 & 0 & 0 & 0 & 0 \\
\hline A49 & 0,97 & 0 & 12,12 & 0 & 33,33 & 0 & 0 & 0 & 0 & 18,18 & 0 & 0 & 0 & 0 & 0 & 0 & 0 \\
\hline A50 & 0,98 & 0 & 0 & 0 & 60,60 & 0 & 3,03 & 0 & 0 & 3,03 & 0 & 0 & 3,03 & 0 & 9,09 & 0 & 0 \\
\hline A51 & 0,98 & 0 & 0 & 0 & 96,97 & 0 & 0 & 0 & 0 & 0 & 0 & 0 & 6,06 & 0 & 0 & 6,06 & 9,09 \\
\hline A52 & 0,98 & 0 & 3,03 & 0 & 66,67 & 0 & 0 & 0 & 0 & 6,06 & 0 & 0 & 0 & 0 & 0 & 0 & 3,03 \\
\hline Média & 0,98 & 0,06 & 3,03 & 2,33 & 72,84 & 1,22 & 1,4 & 0,23 & 0,23 & 7,58 & 0,06 & 0,23 & 0,7 & 0,06 & 0,58 & 0,64 & 1,34 \\
\hline $\begin{array}{l}\text { Desvio } \\
\text { padrão }\end{array}$ & 0,01 & 0,42 & 10,06 & \begin{tabular}{|l|}
4,48 \\
\end{tabular} & 25,19 & 2,63 & 3,26 & 1,68 & 1,68 & 7,81 & 0,42 & 1,01 & 1,54 & 0,42 & 2,25 & 2,11 & 3,08 \\
\hline
\end{tabular}

FNE - Fungos não esporulado

*Coleta 2 - Fase R2 (grão leitoso - 1 semana após a Coleta 1) 


\begin{tabular}{|c|c|c|c|c|c|c|c|c|c|c|c|c|c|c|c|c|}
\hline \multicolumn{2}{|c|}{ Coleta $3 *$} & \multicolumn{15}{|c|}{ Tabela B.3- Porcentagem Contaminação Fúngica } \\
\hline Amostras & $\mathrm{Aa}$ & $\begin{array}{c}\text { Acremonium } \\
\text { spp. }\end{array}$ & $\begin{array}{c}\text { Rhizopus } \\
\text { spp. }\end{array}$ & FNE & Levedura & $\begin{array}{c}\text { Penicillium } \\
\text { spp. }\end{array}$ & $\begin{array}{c}\text { Aspergillus } \\
\text { spp. }\end{array}$ & $\begin{array}{c}\text { Fusarium } \\
\text { verticillioides }\end{array}$ & $\begin{array}{c}\text { Fusarium } \\
\text { anthophilum }\end{array}$ & \begin{tabular}{|c} 
Geotrichum \\
spp.
\end{tabular} & $\begin{array}{c}\text { Trichoderma } \\
\text { spp. }\end{array}$ & $\begin{array}{c}\text { Cladosporium } \\
\text { spp. }\end{array}$ & \begin{tabular}{|c} 
Nigrospora \\
spp.
\end{tabular} & $\begin{array}{c}\text { Neurospora } \\
\text { spp. }\end{array}$ & $\begin{array}{c}\text { Alternaria } \\
\text { spp. }\end{array}$ & $\begin{array}{c}\text { Mucor } \\
\text { spp. }\end{array}$ \\
\hline $\mathrm{A} 1$ & 0,98 & 0 & 0 & 0 & 100 & 0 & 0 & 6,06 & 0 & 0 & 0 & 0 & 0 & 0 & 0 & 0 \\
\hline $\mathrm{A} 2$ & 0,98 & 0 & 0 & 0 & 72,72 & 9,09 & 0 & 9,09 & 0 & 0 & 0 & 0 & 0 & 0 & 0 & 0 \\
\hline A3 & 0,98 & 0 & 0 & 0 & 60,61 & 6,06 & 0 & 15,15 & 0 & 0 & 0 & 0 & 0 & 0 & 0 & 0 \\
\hline A4 & 0,98 & 0 & 0 & 3,03 & 100 & 0 & 0 & 0 & 0 & 0 & 0 & 0 & 0 & 0 & 0 & 0 \\
\hline A5 & 0,98 & 0 & 0 & 15,15 & 97 & 6,06 & 0 & 0 & 0 & 0 & 0 & 0 & 0 & 0 & 0 & 0 \\
\hline A6 & 0,98 & 0 & 0 & 0 & 100 & 0 & 6,06 & 0 & 30,30 & 0 & 0 & 0 & 0 & 0 & 0 & 0 \\
\hline A7 & 0,97 & 0 & 0 & 0 & 100 & 0 & 0 & 21,21 & 0 & 0 & 0 & 0 & 0 & 0 & 0 & 0 \\
\hline A8 & 0,97 & 36,36 & 0 & 0 & 87,88 & 3,03 & 0 & 0 & 0 & 0 & 0 & 3,03 & 0 & 0 & 0 & 0 \\
\hline A9 & 0,98 & 0 & 0 & 0 & 36,36 & 6,06 & 0 & 0 & 0 & 0 & 0 & 3,03 & 0 & 0 & 0 & 0 \\
\hline $\mathrm{A} 10$ & 0,97 & 0 & 0 & 0 & 69,7 & 3,03 & 0 & 36,36 & 0 & 0 & 0 & 3,03 & 0 & 0 & 0 & 0 \\
\hline A11 & 0,97 & 0 & 0 & 0 & 39,39 & 9,09 & 0 & 0 & 57,58 & 0 & 0 & 9,09 & 0 & 0 & 0 & 0 \\
\hline $\mathrm{A} 12$ & 0,97 & 0 & 0 & 0 & 54,55 & 51,52 & 0 & 0 & 0 & 0 & 0 & 3,03 & 0 & 0 & 0 & 0 \\
\hline A13 & 0,97 & 0 & 0 & 0 & 48,49 & 6,06 & 0 & 15,15 & 0 & 0 & 0 & 0 & 0 & 0 & 0 & 0 \\
\hline A14 & 0,97 & 0 & 0 & 0 & 100 & 3,03 & 0 & 42,42 & 0 & 0 & 0 & 3,03 & 0 & 3,03 & 0 & 0 \\
\hline A15 & 0,97 & 0 & 0 & 0 & 100 & 9,09 & 0 & 3,03 & 0 & 12,12 & 0 & 0 & 0 & 0 & 0 & 0 \\
\hline A16 & 0,97 & 0 & 0 & 0 & 48,49 & 0 & 0 & 12,12 & 0 & 0 & 0 & 3,03 & 0 & 0 & 0 & 0 \\
\hline A17 & 0,97 & 3,03 & 0 & 0 & 57,58 & 3,03 & 0 & 0 & 0 & 0 & 0 & 3,03 & 0 & 0 & 0 & 0 \\
\hline A18 & 0,97 & 0 & 0 & 0 & 27,27 & 0 & 0 & 42,42 & 0 & 3,03 & 0 & 0 & 0 & 0 & 0 & 0 \\
\hline A19 & 0,97 & 0 & 0 & 0 & 81,82 & 6,06 & 0 & 6,06 & 0 & 3,03 & 0 & 0 & 0 & 0 & 0 & 0 \\
\hline A20 & 0,97 & 3,03 & 0 & 0 & 36,36 & 27,27 & 0 & 0 & 0 & 0 & 0 & 3,03 & 0 & 0 & 0 & 0 \\
\hline A21 & 0,96 & 3,03 & 0 & 0 & 51,52 & 0 & 0 & 0 & 0 & 0 & 0 & 0 & 0 & 0 & 0 & 0 \\
\hline $\mathrm{A} 22$ & 0,97 & 0 & 0 & 9,09 & 39,39 & 0 & 0 & 0 & 0 & 0 & 3,03 & 12,12 & 0 & 0 & 0 & 0 \\
\hline A23 & 0,96 & 0 & 0 & 0 & 45,46 & 3,03 & 0 & 33,33 & 0 & 0 & 3,03 & 6,06 & 0 & 0 & 3,03 & 6,06 \\
\hline A24 & 0,97 & 0 & 0 & 0 & 81,82 & 27,27 & 0 & 9,09 & 0 & 0 & 0 & 3,03 & 0 & 0 & 0 & 0 \\
\hline A25 & 0,98 & 0 & 0 & 0 & 69,7 & 6,06 & 0 & 3,03 & 0 & 0 & 3,03 & 0 & 0 & 0 & 0 & 0 \\
\hline A26 & 0,97 & 0 & 15,15 & 6,06 & 39,39 & 6,06 & 0 & 0 & 0 & 0 & 0 & 0 & 0 & 0 & 0 & 0 \\
\hline A27 & 0,97 & 0 & 0 & 0 & 33,33 & 0 & 0 & 36,36 & 0 & 9,09 & 0 & 0 & 0 & 0 & 0 & 0 \\
\hline A28 & 0,98 & 0 & 0 & 12,12 & 57,58 & 0 & 0 & 0 & 0 & 0 & 0 & 3,03 & 0 & 0 & 0 & 0 \\
\hline
\end{tabular}




\begin{tabular}{|c|c|c|c|c|c|c|c|c|c|c|c|c|c|c|c|c|}
\hline \multicolumn{2}{|c|}{ Coleta 3* } & \multicolumn{15}{|c|}{ Continuação - Tabela B.3- Porcentagem Contaminação Fúngica } \\
\hline Amostras & Aw & $\begin{array}{c}\text { Acremonium } \\
\text { spp. }\end{array}$ & \begin{tabular}{c|} 
Rhizopus \\
spp.
\end{tabular} & FNE & Levedura & $\begin{array}{c}\text { Penicillium } \\
\text { spp. }\end{array}$ & $\begin{array}{c}\text { Aspergillus } \\
\text { spp. }\end{array}$ & $\begin{array}{c}\text { Fusarium } \\
\text { verticillioides }\end{array}$ & $\begin{array}{c}\text { Fusarium } \\
\text { anthophilum }\end{array}$ & \begin{tabular}{|c|}
$\begin{array}{c}\text { Geotrichum } \\
\text { spp. }\end{array}$ \\
\end{tabular} & \begin{tabular}{|c|}
$\begin{array}{c}\text { Trichoderma } \\
\text { spp. }\end{array}$ \\
\end{tabular} & \begin{tabular}{|c|}
$\begin{array}{c}\text { Cladosporium } \\
\text { spp. }\end{array}$ \\
\end{tabular} & \begin{tabular}{|c|}
$\begin{array}{c}\text { Nigrospora } \\
\text { spp. }\end{array}$ \\
\end{tabular} & \begin{tabular}{|c|} 
Neurospora \\
spp.
\end{tabular} & \begin{tabular}{|c|} 
Alternaria \\
spp.
\end{tabular} & $\begin{array}{c}\text { Mucor } \\
\text { spp. }\end{array}$ \\
\hline A29 & 0,98 & 30,3 & 0 & 0 & 36,36 & 0 & 3,03 & 0 & 0 & 0 & 0 & 3,03 & 0 & 0 & 0 & 0 \\
\hline $\mathrm{A} 30$ & 0,97 & 0 & 0 & 0 & 84,85 & 0 & 0 & 27,27 & 0 & 0 & 0 & 0 & 0 & 0 & 0 & 0 \\
\hline A31 & 0,97 & 21,21 & 0 & 3,03 & 36,36 & 3,03 & 0 & 0 & 0 & 0 & 0 & 6,06 & 0 & 0 & 0 & 0 \\
\hline A32 & 0,97 & 0 & 0 & 33,33 & 24,24 & 0 & 0 & 0 & 0 & 0 & 0 & 3,03 & 0 & 0 & 0 & 0 \\
\hline A33 & 0,97 & 0 & 0 & 0 & 24,24 & 0 & 0 & 45,46 & 0 & 0 & 0 & 0 & 0 & 0 & 0 & 0 \\
\hline A34 & 0,96 & 0 & 0 & 6,06 & 72,72 & 0 & 0 & 27,27 & 0 & 0 & 0 & 0 & 0 & 0 & 0 & 0 \\
\hline A35 & 0,97 & 0 & 3,03 & 0 & 72,72 & 0 & 3,03 & 24,24 & 0 & 0 & 0 & 3,03 & 0 & 0 & 0 & 0 \\
\hline A36 & 0,96 & 0 & 0 & 0 & 39,39 & 3,03 & 0 & 0 & 0 & 21,21 & 0 & 3,03 & 0 & 0 & 0 & 0 \\
\hline A37 & 0,96 & 0 & 3,03 & 0 & 81,82 & 0 & 15,15 & 3.03 & 0 & 3,03 & 3,03 & 0 & 0 & 0 & 0 & 0 \\
\hline A38 & 0,97 & 0 & 0 & 0 & 45,46 & 0 & 0 & 0 & 0 & 18,18 & 0 & 0 & 0 & 0 & 0 & 0 \\
\hline A39 & 0,96 & 0 & 0 & 0 & 42,42 & 0 & 0 & 21,21 & 0 & 0 & 0 & 0 & 0 & 0 & 0 & 0 \\
\hline A40 & 0,97 & 0 & 0 & 0 & 81,82 & 0 & 0 & 0 & 0 & 30,3 & 3,03 & 3,03 & 0 & 0 & 0 & 0 \\
\hline A41 & 0,97 & 0 & 3,03 & 6,06 & 48,49 & 0 & 0 & 0 & 0 & 15,15 & 0 & 18,18 & 0 & 0 & 0 & 0 \\
\hline $\mathrm{A} 42$ & 0,97 & 3,03 & 9,09 & 0 & 81,82 & 3,03 & 0 & 75,76 & 0 & 0 & 9,09 & 6,06 & 0 & 0 & 0 & 0 \\
\hline A43 & 0,97 & 0 & 0 & 0 & 66,67 & 3,03 & 0 & 60,61 & 0 & 0 & 0 & 0 & 0 & 0 & 0 & 0 \\
\hline A44 & 0,97 & 0 & 0 & 0 & 81,82 & 12,12 & 0 & 60,61 & 0 & 0 & 0 & 9,09 & 0 & 0 & 0 & 0 \\
\hline A45 & 0,97 & 0 & 9,09 & 0 & 66,67 & 0 & 0 & 0 & 0 & 60,61 & 0 & 0 & 0 & 0 & 0 & 0 \\
\hline A46 & 0,97 & 0 & 9,09 & 3,03 & 84,85 & 0 & 0 & 81,82 & 0 & 0 & 3,03 & 9,09 & 3,03 & 0 & 0 & 0 \\
\hline A47 & 0,96 & 0 & 3,03 & 9,09 & 54,55 & 0 & 0 & 72,72 & 0 & 0 & 0 & 0 & 0 & 0 & 0 & 0 \\
\hline $\mathrm{A} 48$ & 0,97 & 0 & 0 & 0 & 54,55 & 0 & 0 & 63,63 & 0 & 0 & 0 & 9,09 & 0 & 0 & 0 & 0 \\
\hline A49 & 0,96 & 0 & 0 & 0 & 51,52 & 0 & 0 & 51,52 & 0 & 0 & 0 & 3,03 & 0 & 0 & 0 & 0 \\
\hline A50 & 0,96 & 0 & 0 & 0 & 97 & 0 & 0 & 30,3 & 0 & 0 & 0 & 3,03 & 0 & 0 & 0 & 0 \\
\hline A51 & 0,97 & 0 & 33,33 & 0 & 57,58 & 0 & 0 & 30,3 & 0 & 0 & 0 & 0 & 0 & 0 & 0 & 0 \\
\hline A52 & 0,96 & 0 & 0 & 0 & 48,49 & 0 & 0 & 57,58 & 0 & 0 & 0 & 12,12 & 0 & 0 & 0 & 0 \\
\hline Média & 0,97 & 1,92 & 1,69 & 2,04 & 62,94 & 4,14 & 0,53 & 19,70 & 1,70 & 3,38 & 0,53 & 2,86 & 0,06 & 0,06 & 0,06 & 0,12 \\
\hline $\begin{array}{l}\text { Desvio } \\
\text { padrão }\end{array}$ & 0,01 & 7,05 & 5,38 & 5,56 & 23,14 & 8,84 & 2,3 & 24,37 & 8,95 & 10,16 & 1,56 & 3,95 & 0,42 & 0,42 & 0,42 & 0,84 \\
\hline
\end{tabular}

Aa - Atividade de água

*Coleta 3 - Fase R3 (grão pastoso - 1 semana após Coleta 2) 


\begin{tabular}{|c|c|c|c|c|c|c|c|c|c|c|c|c|c|c|c|c|}
\hline \multicolumn{2}{|c|}{ Coleta $4 *$} & \multicolumn{15}{|c|}{ Tabela B. 4- Porcentagem Contaminação Fúngica } \\
\hline Amostra & $\mathrm{Aa}$ & $\begin{array}{c}\text { Acremonium } \\
\text { spp. }\end{array}$ & $\begin{array}{c}\text { Rhizopus } \\
\text { spp. } \\
\end{array}$ & FNE & Levedura & \begin{tabular}{|c|}
$\begin{array}{c}\text { Penicillium } \\
\text { spp. }\end{array}$ \\
\end{tabular} & \begin{tabular}{|c|}
$\begin{array}{c}\text { Aspergillus } \\
\text { spp. }\end{array}$ \\
\end{tabular} & $\begin{array}{c}\text { Fusarium } \\
\text { verticillioides }\end{array}$ & $\begin{array}{c}\text { Fusarium } \\
\text { sunglutinans }\end{array}$ & $\begin{array}{c}\text { Fusarium } \\
\text { graminearum }\end{array}$ & $\begin{array}{c}\text { Geotrichum } \\
\text { spp }\end{array}$ & $\begin{array}{c}\text { Trichoderma } \\
\text { spp. }\end{array}$ & \begin{tabular}{|c|}
$\begin{array}{c}\text { Cladosporium } \\
\text { spp. }\end{array}$ \\
\end{tabular} & \begin{tabular}{|c|} 
Nigrospora \\
spp
\end{tabular} & $\begin{array}{c}\text { Neurospora } \\
\text { spp. }\end{array}$ & $\begin{array}{c}\text { Mucor } \\
\text { spp. }\end{array}$ \\
\hline A1 & 0,98 & 0 & 0 & 0 & 100 & 0 & 0 & 75,76 & 0 & 0 & 3,03 & 0 & 6,06 & 0 & 0 & 0 \\
\hline A2 & 0,98 & 0 & 0 & 0 & 15,15 & 3,03 & 0 & 57,58 & 0 & 0 & 0 & 6,06 & 3,03 & 0 & 0 & 0 \\
\hline A3 & 0,97 & 0 & 0 & 0 & 27,27 & 0 & 0 & 15,15 & 0 & 0 & 0 & 0 & 3,03 & 0 & 0 & 0 \\
\hline A4 & 0,97 & 0 & 0 & 0 & 54,55 & 0 & 0 & 39,4 & 0 & 0 & 0 & 0 & 12,12 & 0 & 0 & 0 \\
\hline A5 & 0,97 & 0 & 0 & 0 & 27,27 & 0 & 0 & 45,45 & 0 & 0 & 3,03 & 6,06 & 6,06 & 0 & 0 & 0 \\
\hline A6 & 0,97 & 0 & 0 & 0 & 81,82 & 0 & 0 & 66,67 & 0 & 0 & 0 & 0 & 0 & 0 & 0 & 0 \\
\hline A7 & 0,97 & 0 & 0 & 0 & 6,06 & 0 & 0 & 72,73 & 0 & 0 & 0 & 3,03 & 0 & 0 & 0 & 0 \\
\hline A8 & 0,97 & 0 & 0 & 0 & 27,27 & 3,03 & 0 & 27,27 & 0 & 0 & 0 & 0 & 0 & 0 & 6,06 & 0 \\
\hline A9 & 0,97 & 0 & 0 & 0 & 3,03 & 9,09 & 0 & 6,06 & 0 & 0 & 0 & 0 & 6,06 & 0 & 0 & 0 \\
\hline A10 & 0,97 & 0 & 0 & 0 & 78,79 & 0 & 0 & 0 & 0 & 0 & 39,4 & 0 & 3,03 & 0 & 0 & 0 \\
\hline A11 & 0,96 & 0 & 0 & 0 & 36,36 & 0 & 0 & 3,03 & 0 & 0 & 9,09 & 0 & 0 & 0 & 0 & 0 \\
\hline A12 & 0,96 & 0 & 0 & 0 & 88,88 & 0 & 0 & 0 & 0 & 0 & 9,09 & 6,06 & 0 & 0 & 0 & 0 \\
\hline A13 & 0,96 & 0 & 0 & 0 & 3,03 & 0 & 0 & 30,30 & 0 & 0 & 0 & 3,03 & 3,03 & 0 & 0 & 3,03 \\
\hline A14 & 0,96 & 0 & 0 & 6,06 & 72,73 & 0 & 0 & 3,03 & 0 & 0 & 0 & 3,03 & 9,09 & 0 & 0 & 0 \\
\hline A15 & 0,96 & 0 & 0 & 0 & 75,76 & 0 & 0 & 18,18 & 0 & 0 & 0 & 6,06 & 0 & 0 & 0 & 0 \\
\hline A16 & 0,96 & 0 & 0 & 0 & 30,30 & 0 & 0 & 33,33 & 0 & 0 & 0 & 0 & 6,06 & 0 & 0 & 0 \\
\hline A17 & 0,95 & 0 & 3,03 & 0 & 78,79 & 3,03 & 3,03 & 30,30 & 0 & 0 & 3,03 & 0 & 12,12 & 0 & 0 & 0 \\
\hline A18 & 0,96 & 0 & 0 & 0 & 48,49 & 0 & 0 & 42,42 & 0 & 0 & 0 & 3,03 & 0 & 0 & 0 & 0 \\
\hline A19 & 0,96 & 0 & 0 & 12,12 & 60,6 & 3,03 & 0 & 27,27 & 0 & 0 & 3,03 & 0 & 6,06 & 0 & 0 & 0 \\
\hline $\mathrm{A} 20$ & 0,97 & 0 & 0 & 0 & 60,6 & 0 & 0 & 0 & 0 & 0 & 0 & 3,03 & 0 & 0 & 0 & 0 \\
\hline A21 & 0,96 & 0 & 0 & 0 & 48,49 & 0 & 0 & 57,58 & 0 & 0 & 0 & 0 & 3,03 & 0 & 0 & 0 \\
\hline $\mathrm{A} 22$ & 0,95 & 0 & 0 & 0 & 45,46 & 18,18 & 0 & 0 & 0 & 0 & 0 & 3,03 & 0 & 0 & 6,06 & 0 \\
\hline A23 & 0,96 & 0 & 0 & 0 & 45,46 & 0 & 0 & 24,24 & 0 & 0 & 0 & 0 & 3,03 & 0 & 0 & 0 \\
\hline A24 & 0,95 & 0 & 0 & 0 & 75,76 & 0 & 0 & 45,46 & 0 & 0 & 9,09 & 0 & 0 & 0 & 0 & 0 \\
\hline A25 & 0,96 & 0 & 0 & 0 & 24,24 & 0 & 0 & 18,18 & 0 & 0 & 0 & 0 & 12,12 & 0 & 0 & 0 \\
\hline A26 & 0,95 & 0 & 0 & 0 & 57,58 & 3,03 & 0 & 66,67 & 0 & 0 & 0 & 0 & 3,03 & 0 & 0 & 0 \\
\hline A27 & 0,96 & 0 & 12,12 & 0 & 21,21 & 0 & 0 & 42,42 & 0 & 0 & 0 & 0 & 6,06 & 0 & 0 & 0 \\
\hline A28 & 0,96 & 0 & 0 & 3,03 & 36,36 & 0 & 0 & 18,18 & 0 & 0 & 0 & 0 & 6,06 & 0 & 0 & 0 \\
\hline
\end{tabular}




\begin{tabular}{|c|c|c|c|c|c|c|c|c|c|c|c|c|c|c|c|c|}
\hline \multicolumn{2}{|c|}{ Coleta 4* } & \multicolumn{15}{|c|}{ Continuação - Tabela B.4- Porcentagem Contaminação Fúngica } \\
\hline Amostra & Аa & $\begin{array}{c}\text { Acremonium } \\
\text { spp. }\end{array}$ & $\begin{array}{c}\text { Rhizopus } \\
\text { spp. }\end{array}$ & FNE & Levedura & \begin{tabular}{|c|}
$\begin{array}{c}\text { Penicillium } \\
\text { spp. }\end{array}$ \\
\end{tabular} & \begin{tabular}{|c|}
$\begin{array}{c}\text { Aspergillus } \\
\text { spp. }\end{array}$ \\
\end{tabular} & $\begin{array}{c}\text { Fusarium } \\
\text { verticillioides }\end{array}$ & $\begin{array}{c}\text { Fusarium } \\
\text { subglutinans }\end{array}$ & $\begin{array}{c}\text { Fusarium } \\
\text { graminearum }\end{array}$ & \begin{tabular}{|c|} 
Geotrichum \\
Spp
\end{tabular} & $\begin{array}{c}\text { Trichoderma } \\
\text { spp. }\end{array}$ & \begin{tabular}{|c|}
$\begin{array}{c}\text { Cladosporium } \\
\text { spp. }\end{array}$ \\
\end{tabular} & \begin{tabular}{|c|} 
Nigrospora \\
spp
\end{tabular} & $\begin{array}{c}\text { Neurospora } \\
\text { spp. }\end{array}$ & $\begin{array}{c}\text { Mucor } \\
\text { spp. }\end{array}$ \\
\hline A29 & 0,96 & 0 & 0 & 0 & 66,67 & 6,06 & 0 & 12,12 & 0 & 0 & 6,06 & 0 & 9,09 & 0 & 0 & 0 \\
\hline $\mathrm{A} 30$ & 0,95 & 0 & 0 & 0 & 57,58 & 0 & 0 & 0 & 0 & 0 & 12,12 & 0 & 3,03 & 0 & 0 & 0 \\
\hline A31 & 0,95 & 0 & 0 & 3,03 & 57,58 & 3,03 & 0 & 0 & 0 & 0 & 0 & 0 & 3,03 & 0 & 0 & 0 \\
\hline A32 & 0,95 & 0 & 0 & 6,06 & 33,33 & 0 & 6,06 & 0 & 0 & 3,03 & 3,03 & 0 & 3,03 & 0 & 0 & 0 \\
\hline A33 & 0,95 & 6,06 & 0 & 0 & 36,36 & 3,03 & 0 & 0 & 0 & 0 & 0 & 3,03 & 3,03 & 0 & 0 & 0 \\
\hline A34 & 0,96 & 0 & 0 & 3,03 & 45,46 & 0 & 0 & 0 & 0 & 0 & 6,06 & 0 & 3,03 & 0 & 0 & 0 \\
\hline A35 & 0,94 & 0 & 0 & 0 & 63,63 & 0 & 0 & 27,27 & 0 & 0 & 0 & 0 & 3,03 & 3,03 & 0 & 0 \\
\hline A36 & 0,95 & 0 & 0 & 0 & 36,36 & 0 & 0 & 33,33 & 0 & 0 & 3,03 & 0 & 9,09 & 0 & 0 & 0 \\
\hline A37 & 0,95 & 0 & 0 & 0 & 30,30 & 21,21 & 3,03 & 0 & 0 & 0 & 0 & 0 & 3,03 & 0 & 0 & 0 \\
\hline A38 & 0,95 & 0 & 0 & 3,03 & 24,24 & 0 & 21,21 & 24,24 & 0 & 0 & 0 & 6,06 & 3,03 & 0 & 0 & 0 \\
\hline A39 & 0,94 & 0 & 0 & 0 & 27,27 & 0 & 0 & 3,03 & 0 & 0 & 0 & 0 & 3,03 & 0 & 0 & 0 \\
\hline A40 & 0,95 & 0 & 0 & 0 & 30,30 & 0 & 0 & 0 & 0 & 0 & 0 & 0 & 0 & 0 & 0 & 0 \\
\hline A41 & 0,95 & 0 & 0 & 0 & 33,33 & 0 & 0 & 0 & 15,15 & 0 & 6,06 & 9,09 & 0 & 0 & 0 & 0 \\
\hline $\mathrm{A} 42$ & 0,96 & 0 & 0 & 0 & 45,46 & 0 & 0 & 48,49 & 0 & 0 & 0 & 3,03 & 3,03 & 0 & 0 & 0 \\
\hline A43 & 0,96 & 0 & 12,12 & 0 & 51,52 & 0 & 0 & 66,67 & 0 & 0 & 0 & 0 & 0 & 0 & 0 & 0 \\
\hline A44 & 0,95 & 0 & 0 & 0 & 12,12 & 3,03 & 0 & 81,82 & 0 & 0 & 0 & 12,12 & 3,03 & 0 & 0 & 0 \\
\hline A45 & 0,95 & 0 & 12,12 & 0 & 30,30 & 0 & 0 & 48,49 & 0 & 0 & 0 & 0 & 3,03 & 0 & 0 & 0 \\
\hline A46 & 0,95 & 0 & 0 & 0 & 30,30 & 0 & 0 & 33,33 & 0 & 0 & 3,03 & 0 & 0 & 0 & 0 & 0 \\
\hline A47 & 0,95 & 0 & 0 & 0 & 21,21 & 3,03 & 18,18 & 78,79 & 0 & 0 & 0 & 0 & 0 & 0 & 0 & 0 \\
\hline A48 & 0,95 & 0 & 0 & 0 & 90,9 & 0 & 0 & 96,97 & 0 & 0 & 0 & 0 & 6,06 & 0 & 0 & 0 \\
\hline A49 & 0,94 & 0 & 0 & 0 & 27,27 & 0 & 0 & 75,75 & 0 & 0 & 0 & 0 & 0 & 0 & 0 & 0 \\
\hline A50 & 0,95 & 0 & 0 & 0 & 48,49 & 0 & 0 & 51,52 & 0 & 0 & 0 & 0 & 3,03 & 0 & 0 & 0 \\
\hline A51 & 0,94 & 0 & 0 & 0 & 27,27 & 9,09 & 0 & 72,73 & 0 & 0 & 0 & 3,03 & 6,06 & 0 & 0 & 0 \\
\hline A52 & 0,94 & 0 & 0 & 3,03 & 45,46 & 3,03 & 0 & 78,79 & 0 & 0 & 0 & 0 & 0 & 0 & 0 & 0 \\
\hline Média & 0,96 & 0,12 & 0,76 & 0,76 & 44,29 & 1,81 & 0,99 & 32,69 & 0,29 & 0,06 & 2,27 & 1,52 & 3,44 & 0,06 & 0,23 & 0,06 \\
\hline $\begin{array}{l}\text { Desvio } \\
\text { padrão }\end{array}$ & 0,01 & 0,84 & 2,87 & 2,15 & 23,36 & 4,21 & 3,92 & 28,56 & 2,1 & 0,42 & 6,03 & 2,72 & 3,4 & 0,42 & 1,18 & 0,42 \\
\hline
\end{tabular}




\begin{tabular}{|c|c|c|c|c|c|c|c|c|c|c|c|c|c|c|c|}
\hline \multicolumn{2}{|c|}{ Coleta $5^{*}$} & \multicolumn{14}{|c|}{ Tabela B.5- Porcentagem Contaminação Fúngica } \\
\hline Amostras & $\mathrm{Aa}$ & $\begin{array}{l}\text { Acremonium } \\
\text { spp. }\end{array}$ & $\begin{array}{c}\text { Rhizopus } \\
\text { spp. }\end{array}$ & FNE & Levedura & $\begin{array}{c}\text { Penicillium } \\
\text { spp. }\end{array}$ & $\begin{array}{c}\text { Aspergillus } \\
\text { spp. }\end{array}$ & \begin{tabular}{c|c|} 
Fusarium \\
verticillioides
\end{tabular} & \begin{tabular}{|c|}
$\begin{array}{c}\text { Fusarium } \\
\text { proliferatum }\end{array}$ \\
\end{tabular} & $\begin{array}{c}\text { Fusarium } \\
\text { graminearum }\end{array}$ & \begin{tabular}{|c|} 
Fusarium \\
oxysparum
\end{tabular} & $\begin{array}{c}\text { Geotrichum } \\
\text { spp. }\end{array}$ & \begin{tabular}{|c} 
Trichoderma \\
spp.
\end{tabular} & $\begin{array}{c}\text { Cladosporium } \\
\text { spp. }\end{array}$ & $\begin{array}{c}\text { Neurospora } \\
\text { spp. }\end{array}$ \\
\hline A1 & 0,98 & 0 & 0 & 0 & 24,24 & 0 & 0 & 93,94 & 0 & 0 & 0 & 0 & 0 & 3,03 & 0 \\
\hline $\mathrm{A} 2$ & 0,98 & 0 & 0 & 3,03 & 39,39 & 0 & 0 & 57,58 & 0 & 0 & 0 & 0 & 0 & 0 & 0 \\
\hline A3 & 0,97 & 0 & 0 & 0 & 51,52 & 0 & 0 & 87,88 & 0 & 0 & 0 & 0 & 0 & 3,03 & 0 \\
\hline A4 & 0,98 & 0 & 0 & 0 & 6,06 & 0 & 0 & 84,85 & 0 & 0 & 0 & 0 & 0 & 6,06 & 0 \\
\hline A5 & 0,97 & 0 & 0 & 0 & 39,39 & 0 & 0 & 96,97 & 0 & 0 & 0 & 0 & 0 & 12,12 & 0 \\
\hline A6 & 0,98 & 0 & 0 & 0 & 60,6 & 0 & 0 & 84,85 & 0 & 0 & 0 & 0 & 0 & 6,06 & 0 \\
\hline A7 & 0,98 & 0 & 0 & 6,06 & 72,73 & 0 & 0 & 87,88 & 0 & 0 & 0 & 9,09 & 0 & 6,06 & 0 \\
\hline A8 & 0,97 & 0 & 0 & 0 & 36,36 & 0 & 0 & 75,76 & 0 & 0 & 0 & 0 & 0 & 9,09 & 0 \\
\hline A9 & 0,97 & 0 & 0 & 0 & 100 & 0 & 0 & 69,7 & 0 & 0 & 0 & 0 & 3,03 & 6,06 & 0 \\
\hline A10 & 0,98 & 0 & 0 & 0 & 84,85 & 0 & 0 & 100 & 0 & 0 & 0 & 0 & 0 & 0 & 0 \\
\hline A11 & 0,98 & 0 & 0 & 0 & 69,7 & 3,03 & 0 & 96,7 & 0 & 0 & 0 & 0 & 0 & 0 & 0 \\
\hline $\mathrm{A} 12$ & 0,97 & 0 & 0 & 0 & 18,18 & 0 & 0 & 100 & 0 & 0 & 0 & 0 & 0 & 0 & 0 \\
\hline A13 & 0,97 & 0 & 0 & 0 & 96,97 & 3,03 & 0 & 96,97 & 0 & 0 & 0 & 0 & 0 & 3,03 & 0 \\
\hline A14 & 0,98 & 0 & 6,06 & 0 & 24,24 & 0 & 0 & 0 & 0 & 0 & 0 & 0 & 0 & 0 & 0 \\
\hline A15 & 0,98 & 0 & 0 & 0 & 33,33 & 0 & 0 & 51,51 & 0 & 6,06 & 0 & 3,03 & 0 & 0 & 0 \\
\hline A16 & 0,98 & 0 & 0 & 0 & 6,06 & 0 & 0 & 42,420 & 0 & 0 & 0 & 0 & 0 & 0 & 0 \\
\hline A17 & 0,96 & 0 & 0 & 0 & 15,15 & 0 & 0 & 66,67 & 0 & 0 & 0 & 0 & 0 & 0 & 0 \\
\hline A18 & 0,95 & 0 & 0 & 0 & 69,7 & 0 & 0 & 27,27 & 0 & 0 & 0 & 6,06 & 0 & 0 & 0 \\
\hline A19 & 0,97 & 0 & 0 & 0 & 0 & 0 & 0 & 42,42 & 0 & 0 & 0 & 0 & 3,03 & 9,09 & 0 \\
\hline A20 & 0,97 & 0 & 0 & 0 & 15,15 & 0 & 0 & 39,39 & 0 & 0 & 0 & 0 & 0 & 12,12 & 0 \\
\hline A21 & 0,97 & 0 & 0 & 6,06 & 9,09 & 0 & 0 & 36,36 & 0 & 0 & 0 & 0 & 3,03 & 0 & 0 \\
\hline A22 & 0,93 & 0 & 0 & 3,03 & 63,64 & 0 & 0 & 66,66 & 0 & 0 & 0 & 0 & 0 & 18,18 & 0 \\
\hline A23 & 0,97 & 0 & 0 & 6,06 & 93,94 & 0 & 0 & 75,76 & 0 & 0 & 0 & 0 & 0 & 9,09 & 0 \\
\hline A24 & 0,96 & 0 & 0 & 3,03 & 90,91 & 0 & 0 & 57,58 & 0 & 0 & 0 & 0 & 0 & 0 & 0 \\
\hline $\mathrm{A} 25$ & 0,98 & 0 & 0 & 0 & 9,09 & 0 & 0 & 60,6 & 0 & 0 & 0 & 0 & 0 & 3,03 & 0 \\
\hline A26 & 0,98 & 0 & 0 & 0 & 0 & 0 & 6,06 & 30,30 & 3,03 & 0 & 0 & 0 & 0 & 0 & 33,33 \\
\hline A27 & 0,97 & 0 & 0 & 0 & 72,73 & 0 & 0 & 57,58 & 0 & 0 & 0 & 0 & 0 & 3,03 & 0 \\
\hline & & & & & & & & & & & & & & & \\
\hline
\end{tabular}




\begin{tabular}{|c|c|c|c|c|c|c|c|c|c|c|c|c|c|c|c|}
\hline \multicolumn{2}{|c|}{ Coleta 5* } & \multicolumn{14}{|c|}{ Continuação - Tabela B. 5- Porcentagem Contaminação Fúngica } \\
\hline Amostras & $\mathrm{Aa}$ & $\begin{array}{c}\text { Acremonium } \\
\text { spp. }\end{array}$ & $\begin{array}{l}\text { Rhizopus } \\
\text { spp. }\end{array}$ & FNE & Levedura & $\begin{array}{l}\text { Penicillium } \\
\text { spp. }\end{array}$ & $\begin{array}{c}\text { Aspergillus } \\
\text { spp. }\end{array}$ & $\begin{array}{c}\text { Fusarium } \\
\text { verticillioides }\end{array}$ & $\begin{array}{c}\text { Fusarium } \\
\text { proliferatum }\end{array}$ & $\begin{array}{c}\text { Fusarium } \\
\text { graminearum }\end{array}$ & \begin{tabular}{|l|}
$\begin{array}{c}\text { Fusarium } \\
\text { oxusporum }\end{array}$ \\
\end{tabular} & $\begin{array}{l}\text { Geotrichum } \\
\text { spp. }\end{array}$ & $\begin{array}{c}\text { Trichoderma } \\
\text { spp. }\end{array}$ & $\begin{array}{c}\text { Cladosporium } \\
\text { spp. }\end{array}$ & $\begin{array}{c}\text { Neurospora } \\
\text { spp. }\end{array}$ \\
\hline A28 & 0,98 & 0 & 0 & 0 & 45,46 & 0 & 0 & 51,52 & 0 & 0 & 0 & 0 & 0 & 6,06 & 0 \\
\hline A29 & 0,98 & 3,03 & 0 & 9,09 & 15,15 & 3,03 & 0 & 39,39 & 0 & 0 & 0 & 0 & 0 & 0 & 0 \\
\hline $\mathrm{A} 30$ & 0,98 & 0 & 0 & 0 & 3,03 & 0 & 0 & 69,7 & 0 & 0 & 0 & 0 & 0 & 0 & 0 \\
\hline A31 & 0,97 & 0 & 0 & 0 & 0 & 3,03 & 0 & 30,30 & 0 & 0 & 0 & 0 & 0 & 0 & 0 \\
\hline A32 & 0,97 & 0 & 0 & 0 & 0 & 3,03 & 0 & 69,7 & 0 & 0 & 0 & 0 & 0 & 3,03 & 0 \\
\hline A33 & 0,98 & 0 & 0 & 0 & 21,21 & 3,03 & 0 & 42,42 & 0 & 0 & 0 & 0 & 0 & 9,09 & 0 \\
\hline A34 & 0,98 & 0 & 0 & 0 & 27,27 & 0 & 0 & 60,6 & 0 & 0 & 0 & 0 & 0 & 0 & 0 \\
\hline A35 & 0,98 & 0 & 0 & 0 & 72,73 & 0 & 0 & 75,76 & 0 & 0 & 0 & 0 & 0 & 12,12 & 0 \\
\hline A36 & 0,98 & 0 & 0 & 0 & 21,21 & 3,03 & 0 & 75,76 & 0 & 0 & 0 & 0 & 0 & 6,06 & 0 \\
\hline $\mathrm{A} 37$ & 0,98 & 0 & 3,03 & 3,03 & 42,42 & 3,03 & 3,03 & 27,27 & 0 & 0 & 0 & 0 & 0 & 3,03 & 0 \\
\hline A38 & 0,98 & 0 & 0 & 0 & 12,12 & 15,15 & 0 & 0 & 0 & 0 & 30,30 & 0 & 0 & 0 & 0 \\
\hline A39 & 0,95 & 0 & 0 & 0 & 51,52 & 0 & 0 & 36,36 & 0 & 0 & 0 & 0 & 0 & 6,06 & 0 \\
\hline A40 & 0,98 & 0 & 0 & 0 & 6,06 & 3,03 & 0 & 78,79 & 0 & 0 & 0 & 0 & 0 & 3,03 & 0 \\
\hline A41 & 0,98 & 0 & 0 & 0 & 3,03 & 3,03 & 0 & 18,18 & 0 & 0 & 0 & 0 & 6,06 & 3,03 & 0 \\
\hline $\mathrm{A} 42$ & 0,98 & 0 & 0 & 0 & 9,09 & 3,03 & 0 & 96,97 & 0 & 0 & 0 & 0 & 0 & 6,06 & 0 \\
\hline A43 & 0,97 & 0 & 0 & 3,03 & 33,33 & 0 & 0 & 60,60 & 0 & 0 & 0 & 0 & 3,03 & 0 & 0 \\
\hline A44 & 0,98 & 0 & 0 & 0 & 3,03 & 0 & 0 & 75,76 & 0 & 0 & 0 & 0 & 0 & 6,06 & 0 \\
\hline $\mathrm{A} 45$ & 0,98 & 0 & 0 & 3,03 & 0 & 6,06 & 0 & 24,24 & 0 & 0 & 0 & 0 & 0 & 3,03 & 0 \\
\hline A46 & \begin{tabular}{|l|}
0,98 \\
\end{tabular} & 0 & 0 & 0 & 15,15 & 0 & 0 & 69,7 & 0 & 0 & 0 & 0 & 3,03 & 0 & 0 \\
\hline A47 & 0,98 & 0 & 0 & 0 & 9,09 & 0 & 0 & 60,6 & 0 & 0 & 0 & 0 & 0 & 9,09 & 0 \\
\hline A48 & 0,98 & 3,03 & 0 & 0 & 48,49 & 0 & 0 & 51,52 & 0 & 0 & 0 & 0 & 0 & 3,03 & 0 \\
\hline A49 & 0,98 & 0 & 0 & 0 & 9,09 & 0 & 0 & 100 & 0 & 0 & 0 & 0 & 0 & 3,03 & 0 \\
\hline A50 & 0,98 & 0 & 0 & 0 & 24,24 & 0 & 0 & 100 & 0 & 0 & 0 & 0 & 0 & 9,09 & 0 \\
\hline A51 & 0,98 & 0 & 0 & 0 & 0 & 0 & 0 & 93,94 & 0 & 0 & 0 & 0 & 0 & 0 & 0 \\
\hline A52 & 0,98 & 0 & 0 & 0 & 12,12 & 0 & 0 & 87,78 & 0 & 0 & 0 & 0 & 0 & 3,03 & 0 \\
\hline Média & 0,97 & 0,12 & 0,18 & 0,87 & 32,46 & 1,05 & 0,18 & 63,17 & 0,06 & 0,12 & 0,6 & 0,35 & 0,41 & 3,9 & 0,64 \\
\hline $\begin{array}{l}\text { Desvio } \\
\text { padrão }\end{array}$ & 0,01 & 0,59 & 0,93 & 2,02 & 30 & 2,47 & 0,93 & 26,76 & 0 & 0,84 & 0 & 1,55 & 1,2 & 4,26 & 4,62 \\
\hline
\end{tabular}




\begin{tabular}{|c|c|c|c|c|c|c|c|c|c|c|c|c|c|c|c|}
\hline \multicolumn{2}{|c|}{ Coleta 6* } & \multicolumn{14}{|c|}{ Tabela B.6- Porcentagem Contaminação Fúngica } \\
\hline Amostras & $\mathrm{Aa}$ & $\begin{array}{c}\text { Acremonium } \\
\text { spp. }\end{array}$ & FNE & Levedura & $\begin{array}{c}\text { Penicillium } \\
\text { spp. }\end{array}$ & $\begin{array}{c}\text { Aspergillus } \\
\text { spp. }\end{array}$ & $\begin{array}{c}\text { Fusarium } \\
\text { verticillioides }\end{array}$ & $\begin{array}{c}\text { Fusarium } \\
\text { proliferatum }\end{array}$ & $\begin{array}{c}\text { Fusarium } \\
\text { anthophilum }\end{array}$ & $\begin{array}{c}\text { Fusarium } \\
\text { subglutinans }\end{array}$ & $\begin{array}{l}\text { Geotrichum } \\
\text { spp. }\end{array}$ & $\begin{array}{c}\text { Trichoderma } \\
\text { spp. }\end{array}$ & $\begin{array}{c}\text { Cladosporium } \\
\text { spp. }\end{array}$ & $\begin{array}{c}\text { Neurospora } \\
\text { spp. }\end{array}$ & $\begin{array}{c}\text { Mucor } \\
\text { spp. }\end{array}$ \\
\hline A1 & 0,96 & 0 & 0 & 0 & 21,21 & 0 & 100 & 0 & 0 & 0 & 0 & 0 & 42,42 & 0 & 3,03 \\
\hline A3 & 0,95 & 0 & 51,52 & 78,79 & 30,3 & 0 & 60,6 & 0 & 0 & 0 & 0 & 0 & 51,52 & 0 & 0 \\
\hline A4 & 0,96 & 3,03 & 3,03 & 36,36 & 78,79 & 3,03 & 78,79 & 0 & 0 & 0 & 0 & 0 & 30,3 & 0 & 0 \\
\hline A5 & 0,96 & 3,03 & 39,39 & 0 & 15,15 & 0 & 39,39 & 0 & 0 & 0 & 0 & 0 & 48,49 & 0 & 0 \\
\hline A6 & 0,96 & 0 & 0 & 81,82 & 45,46 & 3,03 & 84,85 & 0 & 0 & 0 & 0 & 3,03 & 12,12 & 0 & 0 \\
\hline A7 & 0,96 & 0 & 0 & 36,36 & 21,21 & 0 & 96,97 & 0 & 0 & 0 & 3,03 & 0 & 36,36 & 0 & 0 \\
\hline A8 & 0,96 & 0 & 9,09 & 0 & 12,12 & 0 & 75,76 & 0 & 0 & 0 & 0 & 0 & 39,39 & 33,33 & 0 \\
\hline A9 & 0,95 & 0 & 0 & 39,39 & 9,09 & 0 & 72,73 & 0 & 0 & 0 & 0 & 3,03 & 90,91 & 39,39 & 0 \\
\hline A10 & 0,96 & 0 & 21,21 & 42,42 & 6,06 & 0 & 75,76 & 0 & 0 & 0 & 0 & 0 & 18,18 & 0 & 6,06 \\
\hline A11 & 0,95 & 0 & 0 & 81,82 & 6,06 & 0 & 100 & 0 & 0 & 0 & 0 & 0 & 18,18 & 0 & 0 \\
\hline $\mathrm{A} 12$ & 0,96 & 0 & 33,33 & 21,21 & 6,06 & 3,03 & 30,3 & 0 & 0 & 0 & 0 & 3,03 & 0 & 0 & 0 \\
\hline A14 & 0,98 & 0 & 0 & 15,15 & 6,06 & 6,06 & 24,24 & 0 & 0 & 0 & 0 & 0 & 12,12 & 0 & 0 \\
\hline A15 & 0,98 & 0 & 30,3 & 66,67 & 18,18 & 0 & 45,46 & 0 & 0 & 0 & 0 & 0 & 45,46 & 0 & 0 \\
\hline A16 & 0,98 & 0 & 9,09 & 78,79 & 0 & 0 & 87,88 & 0 & 0 & 0 & 0 & 0 & 48,49 & 0 & 0 \\
\hline A17 & 0,98 & 0 & 0 & 75,76 & 18,18 & 6,06 & 63,64 & 0 & 0 & 0 & 0 & 3,03 & 42,42 & 0 & 0 \\
\hline $\mathrm{A} 18$ & 0,97 & 0 & 24,24 & 6,06 & 15,15 & 0 & 60,6 & 0 & 0 & 0 & 0 & 0 & 63,64 & 0 & 0 \\
\hline A19 & 0,96 & 0 & 15,15 & 30,3 & 15,15 & 0 & 63,64 & 0 & 0 & 0 & 0 & 0 & 30,3 & 0 & 0 \\
\hline $\mathrm{A} 20$ & 0,98 & 0 & 12,12 & 6,06 & 30,3 & 0 & 78,79 & 0 & 0 & 0 & 0 & 0 & 27,27 & 0 & 0 \\
\hline $\mathrm{A} 21$ & 0,98 & 0 & 9,09 & 15,15 & 15,15 & 0 & 66,67 & 0 & 0 & 0 & 0 & 3,03 & 75,76 & 0 & 0 \\
\hline A22 & 0,98 & 0 & 24,24 & 15,15 & 27,27 & 3,03 & 78,79 & 0 & 0 & 0 & 0 & 0 & 78,79 & 0 & 0 \\
\hline A23 & 0,97 & 0 & 0 & 9,09 & 9,09 & 0 & 21,21 & 0 & 0 & 0 & 0 & 6,06 & 36,36 & 0 & 0 \\
\hline A24 & 0,97 & 0 & 9,09 & 0 & 12,12 & 0 & 0 & 0 & 75,76 & 0 & 3,03 & 3,03 & 6,06 & 0 & 0 \\
\hline A25 & 0,97 & 0 & 21,21 & 3,03 & 9,09 & 0 & 78,79 & 0 & 0 & 0 & 0 & 0 & 69,7 & 6,06 & 0 \\
\hline A26 & 0,97 & 0 & 0 & 0 & 0 & 0 & 100 & 0 & 0 & 0 & 0 & 0 & 21,21 & 0 & 0 \\
\hline
\end{tabular}




\begin{tabular}{|c|c|c|c|c|c|c|c|c|c|c|c|c|c|c|c|}
\hline \multicolumn{2}{|c|}{ Coleta 6* } & \multicolumn{14}{|c|}{ Continuação - Tabela B. 6- Porcentagem Contaminação Fúngica } \\
\hline Amostras & $\mathrm{Aa}$ & $\begin{array}{c}\text { Acremonium } \\
\text { spp. }\end{array}$ & FNE & Levedura & $\begin{array}{c}\text { Penicillium } \\
\text { spp. }\end{array}$ & $\begin{array}{c}\text { Aspergillus } \\
\text { spp. }\end{array}$ & $\begin{array}{c}\text { Fusarium } \\
\text { verticillioides }\end{array}$ & $\begin{array}{c}\text { Fusarium } \\
\text { proliferatum }\end{array}$ & $\begin{array}{c}\text { Fusarium } \\
\text { anthophilum }\end{array}$ & $\begin{array}{c}\text { Fusarium } \\
\text { subglutinans }\end{array}$ & $\begin{array}{c}\text { Geotrichum } \\
\text { spp. }\end{array}$ & $\begin{array}{c}\text { Trichoderma } \\
\text { spp. }\end{array}$ & $\begin{array}{c}\text { Cladosporium } \\
\text { spp. }\end{array}$ & $\begin{array}{c}\text { Neurospora } \\
\text { spp. }\end{array}$ & $\begin{array}{c}\text { Mucor } \\
\text { spp. }\end{array}$ \\
\hline $\mathrm{A} 28$ & 0,95 & 0 & 21,21 & 0 & 9,09 & 0 & 87,88 & 0 & 0 & 0 & 3,03 & 0 & 0 & 0 & 0 \\
\hline A30 & 0,95 & 0 & 18,18 & 39,39 & 15,15 & 0 & 78,79 & 0 & 0 & 0 & 0 & 0 & 0 & 0 & 0 \\
\hline A31 & 0,95 & 0 & 30,3 & 33,33 & 0 & 9,09 & 54,55 & 0 & 0 & 0 & 0 & 0 & 0 & 0 & 0 \\
\hline A32 & 0,95 & 0 & 24,24 & 27,27 & 30,3 & 3,03 & 66,67 & 0 & 0 & 0 & 0 & 0 & 0 & 0 & 0 \\
\hline A33 & 0,96 & 0 & 27,27 & 15,15 & 0 & 3,03 & 0 & 0 & 0 & 39,39 & 0 & 0 & 0 & 0 & 0 \\
\hline A34 & 0,98 & 0 & 15,15 & 0 & 12,12 & 0 & 0 & 84,85 & 0 & 0 & 0 & 0 & 0 & 0 & 0 \\
\hline A35 & 0,96 & 0 & 0 & 0 & 12,12 & 3,03 & 100 & 0 & 0 & 0 & 0 & 0 & 0 & 0 & 0 \\
\hline A36 & 0,96 & 0 & 0 & 0 & 27,27 & 12,12 & 72,73 & 0 & 0 & 0 & 0 & 3,03 & 0 & 0 & 0 \\
\hline A37 & 0,97 & 0 & 9,09 & 27,27 & 0 & 6,06 & 84,85 & 0 & 0 & 0 & 0 & 0 & 0 & 0 & 0 \\
\hline A38 & 0,96 & 0 & 15,15 & 75,76 & 21,21 & 0 & 81,82 & 0 & 0 & 0 & 0 & 0 & 0 & 0 & 0 \\
\hline A39 & 0,96 & 0 & 0 & 27,27 & 6,06 & 0 & 100 & 0 & 0 & 0 & 0 & 0 & 0 & 0 & 0 \\
\hline A41 & 0,95 & 0 & 21,21 & 12,12 & 6,06 & 3,03 & 72,73 & 0 & 0 & 0 & 0 & 0 & 27,27 & 0 & 0 \\
\hline A42 & 0,95 & 0 & 0 & 0 & 9,09 & 0 & 100 & 0 & 0 & 0 & 0 & 0 & 54,55 & 0 & 0 \\
\hline A43 & 0,94 & 0 & 0 & 9,09 & 81,82 & 0 & 57,58 & 0 & 0 & 0 & 0 & 0 & 66,67 & 0 & 0 \\
\hline A44 & 0,95 & 0 & 12,12 & 18,18 & 15,15 & 0 & 93,94 & 0 & 0 & 0 & 0 & 0 & 24,24 & 0 & 0 \\
\hline A45 & 0,93 & 0 & 33,33 & 0 & 36,36 & 6,06 & 33,33 & 0 & 0 & 0 & 0 & 0 & 66,67 & 0 & 3,03 \\
\hline A46 & 0,94 & 0 & 18,18 & 6,06 & 18,18 & 6,06 & 84,85 & 0 & 0 & 0 & 0 & 0 & 60,6 & 3,03 & 0 \\
\hline $\mathrm{A} 47$ & 0,92 & 0 & 9,09 & 0 & 15,15 & 0 & 100 & 0 & 0 & 0 & 0 & 0 & 93,94 & 0 & 0 \\
\hline A48 & 0,94 & 0 & 30,3 & 0 & 15,15 & 0 & 57,58 & 0 & 0 & 0 & 0 & 0 & 57,58 & 0 & 0 \\
\hline A49 & 0,94 & 0 & 18,18 & 30,3 & 6,06 & 0 & 100 & 0 & 0 & 0 & 0 & 3,03 & 75,76 & 0 & 0 \\
\hline A50 & 0,95 & 0 & 12,12 & 15,15 & 0 & 0 & 100 & 0 & 0 & 0 & 0 & 3,03 & 24,24 & 0 & 0 \\
\hline A51 & 0,92 & 0 & 9,09 & 0 & 15,15 & 0 & 100 & 0 & 0 & 0 & 0 & 0 & 96,97 & 0 & 0 \\
\hline A52 & 0,94 & 0 & 6,06 & 6,06 & 0 & 9,09 & 96,97 & 0 & 0 & 0 & 0 & 0 & 69,7 & 0 & 0 \\
\hline Média & 0,96 & 0,12 & 14,1 & 22,49 & 17,08 & 1,92 & 70,98 & 1,63 & 1,46 & 0,76 & 0,18 & 0,7 & 33,92 & 1,57 & 0,23 \\
\hline
\end{tabular}




\begin{tabular}{|c|c|c|c|c|c|c|c|c|c|c|c|}
\hline \multicolumn{2}{|c|}{ Coleta 7* } & \multicolumn{10}{|c|}{ Tabela B.7- Porcentagem Contaminação Fúngica } \\
\hline Amostras & $\mathrm{Aa}$ & $\begin{array}{c}\text { Acremonium } \\
\text { spp. }\end{array}$ & FNE & Levedura & $\begin{array}{c}\text { Penicillium } \\
\text { spp. }\end{array}$ & $\begin{array}{c}\text { Aspergillus } \\
\text { spp. }\end{array}$ & $\begin{array}{c}\text { Fusarium } \\
\text { verticillioides }\end{array}$ & Trichoderma spp. & Cladosporium spp. & Nigrospora spp & $\begin{array}{c}\text { Neurospora } \\
\text { spp. }\end{array}$ \\
\hline A1 & 0,97 & 0 & 0 & 42,42 & 78,79 & 0 & 93,94 & 0 & 0 & 0 & 0 \\
\hline $\mathrm{A} 2$ & 0,97 & 0 & 0 & 24,24 & 100 & 0 & 45,46 & 0 & 0 & 0 & 0 \\
\hline A3 & 0,97 & 0 & 0 & 0 & 63,64 & 0 & 30,3 & 0 & 0 & 0 & 0 \\
\hline A4 & 0,97 & 0 & 0 & 18,18 & 60,61 & 0 & 60,61 & 0 & 0 & 0 & 0 \\
\hline A5 & 0,96 & 0 & 0 & 6,06 & 90,91 & 0 & 18,18 & 0 & 0 & 0 & 0 \\
\hline A6 & 0,95 & 0 & 0 & 0 & 81,82 & 0 & 66,67 & 0 & 0 & 0 & 0 \\
\hline A7 & 0,96 & 0 & 0 & 0 & 27,27 & 0 & 100 & 0 & 0 & 0 & 66,67 \\
\hline A8 & 0,96 & 0 & 0 & 0 & 90,91 & 0 & 30,3 & 90,91 & 0 & 0 & 0 \\
\hline A9 & 0,97 & 0 & 0 & 21,21 & 100 & 0 & 100 & 0 & 0 & 0 & 0 \\
\hline $\mathrm{A} 10$ & 0,96 & 0 & 21,21 & 9,09 & 51,52 & 0 & 30,3 & 0 & 0 & 0 & 0 \\
\hline A11 & 0,95 & 0 & 21,21 & 9,09 & 15,15 & 0 & 51,52 & 9,09 & 0 & 0 & 0 \\
\hline A12 & 0,97 & 0 & 0 & 0 & 90,91 & 0 & 75,76 & 75,76 & 0 & 0 & 0 \\
\hline A13 & 0,96 & 0 & 0 & 0 & 84,85 & 0 & 39,39 & 0 & 0 & 0 & 0 \\
\hline A14 & 0,95 & 0 & 0 & 0 & 72,73 & 0 & 27,27 & 0 & 21,21 & 6,06 & 0 \\
\hline A15 & 0,96 & 0 & 0 & 0 & 6,06 & 0 & 66,67 & 12,12 & 0 & 9,09 & 0 \\
\hline A16 & 0,96 & 0 & 0 & 0 & 81,82 & 0 & 78,79 & 0 & 0 & 0 & 0 \\
\hline A17 & 0,96 & 0 & 0 & 0 & 75,76 & 0 & 39,39 & 0 & 0 & 9,09 & 0 \\
\hline $\mathrm{A} 18$ & 0,95 & 0 & 0 & 0 & 48,49 & 0 & 57,58 & 0 & 0 & 0 & 0 \\
\hline A19 & 0,96 & 0 & 0 & 9,09 & 75,76 & 0 & 69,7 & 0 & 0 & 0 & 0 \\
\hline $\mathrm{A} 20$ & 0,96 & 0 & 0 & 18,18 & 84,85 & 0 & 84,85 & 0 & 0 & 0 & 0 \\
\hline $\mathrm{A} 21$ & 0,95 & 0 & 0 & 18,18 & 69,7 & 3,03 & 45,46 & 0 & 0 & 0 & 0 \\
\hline A22 & 0,96 & 0 & 0 & 3,03 & 100 & 0 & 42,42 & 0 & 0 & 0 & 0 \\
\hline A23 & 0,95 & 0 & 0 & 9,09 & 9,09 & 0 & 100 & 0 & 0 & 0 & 0 \\
\hline A24 & 0,95 & 0 & 0 & 12,12 & 12,12 & 0 & 48,49 & 33,33 & 0 & 0 & 0 \\
\hline A25 & 0,96 & 0 & 0 & 0 & 75,76 & 0 & 0 & 51,52 & 0 & 0 & 0 \\
\hline A26 & 0,89 & 0 & 0 & 0 & 100 & 0 & 0 & 0 & 0 & 0 & 0 \\
\hline
\end{tabular}




\begin{tabular}{|c|c|c|c|c|c|c|c|c|c|c|c|}
\hline \multicolumn{2}{|c|}{ Coleta $7 *$} & \multicolumn{10}{|c|}{ Continuação - Tabela B.7- Porcentagem Contaminação Fúngica } \\
\hline Amostras & $\mathrm{Aa}$ & $\begin{array}{c}\text { Acremonium } \\
\text { spp. }\end{array}$ & FNE & Levedura & $\begin{array}{c}\text { Penicillium } \\
\text { spp. }\end{array}$ & $\begin{array}{c}\text { Aspergillus } \\
\text { spp. }\end{array}$ & $\begin{array}{c}\text { Fusarium } \\
\text { verticillioides }\end{array}$ & Trichoderma spp. & Cladosporium spp. & Nigrospora spp & $\begin{array}{c}\text { Neurospora } \\
\text { spp. }\end{array}$ \\
\hline A27 & 0,95 & 0 & 0 & 0 & 96,97 & 0 & 18,18 & 0 & 0 & 0 & 0 \\
\hline A28 & 0,96 & 0 & 0 & 0 & 54,55 & 0 & 60,61 & 0 & 0 & 0 & 0 \\
\hline A29 & 0,96 & 0 & 0 & 0 & 3,03 & 0 & 100 & 0 & 0 & 0 & 0 \\
\hline $\mathrm{A} 30$ & 0,94 & 0 & 0 & 0 & 51,52 & 0 & 54,55 & 0 & 0 & 0 & 0 \\
\hline A31 & 0,95 & 0 & 0 & 0 & 57,58 & 0 & 45,46 & 0 & 0 & 0 & 0 \\
\hline A32 & 0,95 & 0 & 0 & 0 & 75,76 & 0 & 30,3 & 24,24 & 0 & 0 & 0 \\
\hline A33 & 0,95 & 0 & 0 & 6,06 & 45,46 & 0 & 90,91 & 3,03 & 0 & 0 & 0 \\
\hline A34 & 0,96 & 0 & 0 & 0 & 100 & 3,03 & 12,12 & 24,24 & 0 & 0 & 0 \\
\hline A35 & 0,95 & 0 & 9,09 & 0 & 60,61 & 0 & 36,36 & 3,03 & 0 & 0 & 0 \\
\hline A36 & 0,95 & 0 & 0 & 12,12 & 69,7 & 0 & 27,27 & 36,36 & 0 & 0 & 0 \\
\hline A37 & 0,95 & 0 & 0 & 0 & 54,55 & 0 & 100 & 0 & 3,03 & 0 & 0 \\
\hline A38 & 0,95 & 0 & 0 & 0 & 36,36 & 0 & 90,91 & 0 & 0 & 0 & 33,33 \\
\hline A39 & 0,95 & 0 & 0 & 15,15 & 87,88 & 0 & 30,3 & 0 & 0 & 0 & 0 \\
\hline $\mathrm{A} 40$ & 0,96 & 0 & 0 & 0 & 93,94 & 0 & 6,06 & 3,03 & 3,03 & 0 & 0 \\
\hline A41 & 0,95 & 0 & 0 & 0 & 33,33 & 0 & 96,97 & 0 & 0 & 0 & 0 \\
\hline $\mathrm{A} 42$ & 0,95 & 0 & 0 & 0 & 66,67 & 0 & 18,18 & 6,06 & 0 & 0 & 0 \\
\hline $\mathrm{A} 43$ & 0,96 & 0 & 0 & 0 & 60,61 & 0 & 60,61 & 0 & 0 & 0 & 0 \\
\hline A44 & 0,97 & 0 & 0 & 0 & 100 & 0 & 12,12 & 66,67 & 0 & 9,09 & 0 \\
\hline A45 & 0,96 & 0 & 0 & 15,15 & 84,85 & 0 & 72,73 & 0 & 0 & 0 & 0 \\
\hline A46 & 0,96 & 0 & 0 & 24,24 & 45,46 & 0 & 42,42 & 0 & 0 & 0 & 0 \\
\hline A47 & 0,93 & 0 & 0 & 0 & 48,49 & 0 & 72,73 & 0 & 3,03 & 0 & 0 \\
\hline A48 & 0,94 & 3,03 & 0 & 12,12 & 100 & 0 & 42,42 & 0 & 0 & 0 & 0 \\
\hline A49 & 0,96 & 0 & 0 & 0 & 60,61 & 0 & 100 & 9,09 & 0 & 0 & 0 \\
\hline A50 & 0,96 & 0 & 9,09 & 0 & 57,58 & 0 & 18,18 & 24,24 & 0 & 6,06 & 0 \\
\hline A51 & 0,96 & 0 & 0 & 9,09 & 63,64 & 0 & 63,64 & 0 & 0 & 0 & 0 \\
\hline A52 & 0,95 & 0 & 0 & 0 & 15,15 & 0 & 100 & 3,03 & 0 & 3,03 & 0 \\
\hline Média & 0,96 & 0,06 & 1,17 & 5,65 & 64,86 & 0,12 & 53,96 & 9,15 & 0,58 & 0,82 & 1,92 \\
\hline $\begin{array}{l}\text { Desvio } \\
\text { padrão }\end{array}$ & 0,01 & 0,42 & 4,42 & 9,02 & 27,66 & 0,59 & 30,33 & 20,45 & 3 & 2,41 & 10,26 \\
\hline
\end{tabular}


Tabela B.8. Expressão gênica relativa das amostras da coleta 1 que expressaram todo o cluster FUM estudado em relação à amostra calibradora (linha assinalada em cinza) e a porcentagem de contaminação por $F$. verticillioides nas respectivas amostras.

\begin{tabular}{|c|c|c|c|c|c|c|c|c|c|c|c|c|c|c|c|c|c|}
\hline Coleta 1 & $\begin{array}{c}\text { FUM } \\
1\end{array}$ & $\begin{array}{c}\text { FUM } \\
2\end{array}$ & $\begin{array}{c}\text { FUM } \\
6\end{array}$ & $\begin{array}{c}\text { FUM } \\
7\end{array}$ & $\begin{array}{c}\text { FUM } \\
8\end{array}$ & $\begin{array}{c}\text { FUM } \\
9\end{array}$ & $\begin{array}{c}\text { FUM } \\
10\end{array}$ & $\begin{array}{c}\text { FUM } \\
11\end{array}$ & $\begin{array}{c}\text { FUM } \\
13\end{array}$ & $\begin{array}{c}\text { FUM } \\
14\end{array}$ & $\begin{array}{c}\text { FUM } \\
15\end{array}$ & $\begin{array}{c}\text { FUM } \\
16\end{array}$ & $\begin{array}{c}\text { FUM } \\
17\end{array}$ & $\begin{array}{c}\text { FUM } \\
18\end{array}$ & $\begin{array}{c}\text { FUM } \\
19\end{array}$ & $\begin{array}{c}\text { FUM } \\
21\end{array}$ & $\begin{array}{c}\text { Cont. } \\
\text { F.v. }(\%)^{*}\end{array}$ \\
\hline $\mathrm{A} 2$ & 9,63 & 10,4 & 6,91 & 8,39 & 25,4 & 8,86 & 7,99 & 10,62 & 28,21 & 7,25 & 3,78 & 2,49 & 15,87 & 24,05 & 3,97 & 4,53 & 0 \\
\hline $\mathrm{A} 12$ & 0,49 & 0,61 & 0,39 & 0,3 & 0,71 & 0,81 & 0,27 & 0,17 & 0,83 & 0,12 & 0,15 & 0,17 & 0,54 & 0,12 & 0,13 & 0,11 & 0 \\
\hline A18 & 28,01 & 60,9 & 37,74 & 19,27 & 18 & 23,89 & 16,43 & 15,22 & 31,52 & 15,76 & 11,3 & 10,69 & 28,01 & 50,5 & 15,98 & 13,91 & 6,06 \\
\hline A19 & 0,42 & 0,78 & 0,71 & 0,6 & 0,44 & 0,56 & 0,27 & 0,2 & 1,07 & 0,25 & 0,27 & 0,35 & 0,43 & 0,14 & 0,27 & 0,3 & 0 \\
\hline A26 & 5,97 & 7,35 & 4,59 & 2 & 3,63 & 2,25 & 2,38 & 3,6 & 10,11 & 0,61 & 2,86 & 3,16 & 3,75 & 6,22 & 3,36 & 2,48 & 0 \\
\hline A29 & 1,0 & 1,0 & 1,0 & 1,0 & 1,0 & 1,0 & 1,0 & 1,0 & 1,0 & 1,0 & 1,0 & 1,0 & 1,0 & 1,0 & 1,0 & 1,0 & 0 \\
\hline A31 & 3,31 & 4,53 & 4,28 & 1,57 & 2,26 & 2,69 & 1,29 & 1,56 & 2,67 & 1,3 & 1,52 & 4,49 & 1,92 & 0,53 & 1,39 & 1,53 & 0 \\
\hline A34 & 24,39 & 20,9 & 10,54 & 13,07 & 34,7 & 16,31 & 7,45 & 8,44 & 16,77 & 15,54 & 9,77 & 16,2 & 23,56 & 28,01 & 9,77 & 8,74 & 0 \\
\hline A36 & 24,56 & 16,2 & 9,05 & 13,25 & 30,4 & 11,46 & 4,82 & 4,82 & 13,07 & 10,4 & 8,21 & 12,36 & 15,01 & 19,95 & 7,88 & 6,96 & 0 \\
\hline A37 & 0,45 & 0,81 & 0,58 & 0,76 & 0,44 & 0,28 & 0,26 & 0,3 & 0,61 & 0,5 & 0,38 & 0,48 & 0,46 & 0,87 & 0,17 & 0,25 & 0 \\
\hline A39 & 6,01 & 11 & 3,99 & 2,88 & 7,45 & 6,72 & 0,07 & 4,49 & 10,99 & 3,45 & 3,18 & 9,05 & 4,46 & 7 & 1,71 & 4,28 & 0 \\
\hline A44 & 15,98 & 30 & 21,68 & 10,25 & 12,3 & 31,74 & 11,7 & 7,3 & 15,65 & 57,6 & 23,89 & 11,54 & 39,89 & 0,16 & 16,2 & 21,23 & 0 \\
\hline A45 & 4,37 & 5,38 & 5,77 & 4,72 & 5,65 & 3,11 & 3,91 & 1,67 & 6,18 & 4,75 & 6,53 & 5,27 & 6,44 & 2,97 & 0,29 & 2,79 & 0 \\
\hline A47 & 2,33 & 4,82 & 2 & 3,07 & 3,24 & 1,67 & 1,84 & 1,34 & 3,75 & 0,22 & 1,39 & 2,79 & 3,13 & 3,5 & 0,91 & 1,03 & 12,12 \\
\hline A48 & 0,44 & 0,55 & 0,31 & 0,27 & 0,39 & 0,27 & 0,12 & 0,15 & 0,49 & 0,26 & 0,53 & 0,52 & 0,37 & 0,21 & 0,08 & 0,23 & 0 \\
\hline A52 & 1,2 & 1,58 & 2,9 & 0,74 & 1,33 & 0,9 & 1,25 & 0,96 & 1,93 & 0,96 & 0,81 & 1,9 & 0,8 & 1,36 & 0,51 & 1,1 & 18,18 \\
\hline
\end{tabular}

*Porcentagem de grãos em uma amostra dos quais foram isolados $F$. verticillioides 
Tabela B.9. Expressão gênica relativa das amostras da coleta 2 que expressaram todo o cluster FUM estudado em relação à amostra calibradora (linha assinalada em cinza) e a porcentagem de contaminação por $F$. verticillioides nas respectivas amostras.

\begin{tabular}{|c|c|c|c|c|c|c|c|c|c|c|c|c|c|c|c|c|c|}
\hline Coleta 2 & $\begin{array}{c}\text { FUM } \\
1\end{array}$ & $\begin{array}{c}\text { FUM } \\
2\end{array}$ & $\begin{array}{c}\text { FUM } \\
6\end{array}$ & $\begin{array}{c}\text { FUM } \\
7\end{array}$ & $\begin{array}{c}\text { FUM } \\
8\end{array}$ & $\begin{array}{c}\text { FUM } \\
9\end{array}$ & $\begin{array}{c}\text { FUM } \\
10\end{array}$ & $\begin{array}{c}\text { FUM } \\
11\end{array}$ & $\begin{array}{c}\text { FUM } \\
13\end{array}$ & $\begin{array}{c}\text { FUM } \\
14\end{array}$ & $\begin{array}{c}\text { FUM } \\
15\end{array}$ & $\begin{array}{c}\text { FUM } \\
16\end{array}$ & $\begin{array}{c}\text { FUM } \\
17\end{array}$ & $\begin{array}{c}\text { FUM } \\
18\end{array}$ & $\begin{array}{c}\text { FUM } \\
19\end{array}$ & $\begin{array}{c}\text { FUM } \\
21\end{array}$ & $\begin{array}{l}\text { Cont. } \\
\text { F.v. (\%) }\end{array}$ \\
\hline A5 & 4,43 & 3,29 & 4,85 & 9,05 & 1,83 & 2,46 & 4,72 & 6,14 & 5,09 & 4,95 & 9,9 & 4,46 & 5,27 & 4,19 & 3,18 & 4,43 & 0 \\
\hline A7 & 3,41 & 2,16 & 3,11 & 4,85 & 1,49 & 2,55 & 3,6 & 3,63 & 3,73 & 5,97 & 7,88 & 4,95 & 3,68 & 5,09 & 0,74 & 3,53 & 0 \\
\hline A9 & 3,5 & 2,6 & 5,61 & 0,22 & 2,17 & 2,33 & 5,69 & 6,63 & 7,99 & 6,27 & 12,89 & 6,22 & 2,14 & 4,56 & 3,7 & 7,88 & 0 \\
\hline A15 & 3,7 & 3,58 & 13,53 & 6,14 & 3,55 & 6,01 & 2,88 & 6,27 & 9,63 & 5,16 & 5,09 & 8,68 & 3,13 & 7,15 & 15,22 & 7,93 & 0 \\
\hline A16 & 2,71 & 4,05 & 5,2 & 3,81 & 1,78 & 3,2 & 4,56 & 4,78 & 5,02 & 4,69 & 9,44 & 5,93 & 3,34 & 6,53 & 3,83 & 7,3 & 0 \\
\hline A17 & 5,09 & 4,22 & 3,86 & 1,66 & 2,49 & 1,31 & 2,43 & 6,14 & 2,48 & 8,33 & 6,72 & 5,85 & 1,13 & 2,17 & 3,7 & 3,09 & 0 \\
\hline A18 & 0,14 & 0,1 & 0,28 & 0,26 & 0,11 & 0,11 & 0,24 & 0,24 & 0,21 & 0,48 & 0,13 & 0,16 & 0,18 & 0,13 & 0,11 & 0,11 & 12,12 \\
\hline A24 & 3,34 & 2,75 & 7,35 & 6,49 & 3,2 & 6,91 & 3,07 & 8,99 & 5,34 & 7,72 & 8,27 & 3,36 & 3,18 & 7 & 12,98 & 2,99 & 0 \\
\hline A28 & 46,79 & 23,1 & 52,28 & 23,72 & 24,6 & 22,13 & 17,73 & 29,41 & 48,44 & 10,69 & 25,07 & 20,23 & 29 & 27,63 & 56,03 & 10,69 & 0 \\
\hline A30 & 0,59 & 0,32 & 0,47 & 0,64 & 0,18 & 0,51 & 0,34 & 1,75 & 0,73 & 0,11 & 1,38 & 0,93 & 0,8 & 0,55 & 1,47 & 0,54 & 0 \\
\hline A32 & 1,46 & 1,85 & 1,45 & 4,05 & 0,85 & 1,27 & 2,16 & 3,55 & 1,76 & 6,81 & 1,27 & 1,2 & 1,03 & 1,88 & 4,37 & 1,63 & 0 \\
\hline A34 & 5,97 & 4,43 & 1,86 & 5,2 & 2,14 & 3,13 & 3,75 & 5,97 & 3,99 & 4,88 & 2,13 & 3,24 & 3,31 & 4,28 & 5,23 & 2,86 & 0 \\
\hline A35 & 1,27 & 0,67 & 0,83 & 0,88 & 0,94 & 1,8 & 0,96 & 1,75 & 4,46 & 2,77 & 1,68 & 1,26 & 0,11 & 1,24 & 2,22 & 1,57 & 0 \\
\hline A48 & 0,82 & 0,49 & 0,43 & 0,59 & 0,28 & 0,54 & 0,41 & 0,38 & 0,5 & 2,56 & 0,63 & 0,41 & 0,6 & 0,64 & 1,11 & 0,41 & 0 \\
\hline A50 & 1,0 & 1,0 & 1,0 & 1,0 & 1,0 & 1,0 & 1,0 & 1,0 & 1,0 & 1,0 & 1,0 & 1,0 & 1,0 & 1,0 & 1,0 & 1,0 & 0 \\
\hline A51 & 0,22 & 0,21 & 0,1 & 0,14 & 0,12 & 0,31 & 0,13 & 0,2 & 0,45 & 0,57 & 0,28 & 0,1 & 0,14 & 0,19 & 0,12 & 0,29 & 0 \\
\hline A52 & 12,19 & 3,41 & 4,46 & 8,99 & 5,42 & 8,16 & 6,22 & 11,14 & 10,47 & 6,91 & 7,1 & 7,05 & 7,77 & 8,68 & 10,69 & 8,39 & 0 \\
\hline
\end{tabular}

*Porcentagem de grãos em uma amostra dos quais foram isolados $F$. verticillioides 
Tabela B.10. Expressão gênica relativa das amostras da coleta 3 que expressaram todo o cluster FUM estudado em relação à amostra calibradora (linha assinalada em cinza) e a porcentagem de contaminação por $F$. verticillioides nas respectivas amostras.

\begin{tabular}{|c|c|c|c|c|c|c|c|c|c|c|c|c|c|c|c|c|c|}
\hline Coleta 3 & $\begin{array}{c}\text { FUM } \\
1\end{array}$ & $\begin{array}{c}\text { FUM } \\
2\end{array}$ & $\begin{array}{c}\text { FUM } \\
6\end{array}$ & $\begin{array}{c}\text { FUM } \\
7\end{array}$ & $\begin{array}{c}\text { FUM } \\
8\end{array}$ & $\begin{array}{c}\text { FUM } \\
9\end{array}$ & $\begin{array}{l}\text { FUM } \\
10\end{array}$ & $\begin{array}{c}\text { FUM } \\
11\end{array}$ & $\begin{array}{c}\text { FUM } \\
13\end{array}$ & $\begin{array}{c}\text { FUM } \\
14\end{array}$ & $\begin{array}{l}\text { FUM } \\
15\end{array}$ & $\begin{array}{l}\text { FUM } \\
16\end{array}$ & $\begin{array}{c}\text { FUM } \\
17\end{array}$ & $\begin{array}{c}\text { FUM } \\
18\end{array}$ & $\begin{array}{c}\text { FUM } \\
19\end{array}$ & $\begin{array}{c}\text { FUM } \\
21\end{array}$ & $\begin{array}{l}\text { Cont. } \\
\text { F.v. (\%) }\end{array}$ \\
\hline $\mathrm{A} 1$ & 0,17 & 0,25 & 0,14 & 0,16 & 0,13 & 0,16 & 0,11 & 0,17 & 0,14 & 0,47 & 0,25 & 0,11 & 0,14 & 0,27 & 0,33 & 0,12 & 6,06 \\
\hline A3 & 0,16 & 0,24 & 0,17 & 0,1 & 0,11 & 0,32 & 0,23 & 0,1 & 0,14 & 0,1 & 0,16 & 0,14 & 0,13 & 0,22 & 0,16 & 0,16 & 15,15 \\
\hline A4 & 2,65 & 6,36 & 3,58 & 2,14 & 1,15 & 2,81 & 4,19 & 3,16 & 1,59 & 0,61 & 1,47 & 0,98 & 2,04 & 2,73 & 3,07 & 0,83 & 0 \\
\hline A5 & 6,31 & 6,1 & 5,16 & 3,18 & 2,97 & 4,28 & 1,97 & 2,39 & 4,69 & 5,46 & 2,82 & 2,88 & 3,45 & 3,05 & 3,83 & 2,88 & 0 \\
\hline A6 & 1,13 & 2,01 & 1,26 & 0,69 & 0,76 & 1,31 & 1,47 & 0,64 & 0,86 & 0,98 & 1,03 & 0,86 & 0,96 & 1,24 & 1,17 & 5,89 & 0 \\
\hline A7 & 3,18 & 5,61 & 2,84 & 2,03 & 2,19 & 2,46 & 2,16 & 2,64 & 1,62 & 4,28 & 2,29 & 0,99 & 1,06 & 2,58 & 2,07 & 1,78 & 21,21 \\
\hline A10 & 1,0 & 1,0 & 1,0 & 1,0 & 1,0 & 1,0 & 1,0 & 1,0 & 1,0 & 1,0 & 1,0 & 1,0 & 1,0 & 1,0 & 1,0 & 1,0 & 36,36 \\
\hline A13 & 35,21 & 26,5 & 29 & 15,01 & 20,1 & 18,48 & 16,31 & 25,78 & 11,86 & 0,18 & 10,25 & 14,01 & 19,67 & 18,87 & 16,09 & 19 & 15,15 \\
\hline A18 & 0,3 & 0,27 & 0,28 & 0,36 & 0,17 & 0,61 & 0,35 & 0,4 & 0,34 & 0,23 & 0,21 & 0,27 & 0,22 & 0,13 & 0,48 & 0,3 & 42,42 \\
\hline A19 & 19,81 & 26,7 & 18,1 & 25,78 & 30,2 & 23,56 & 14,7 & 31,3 & 14,91 & 35,21 & 20,09 & 9,77 & 10,11 & 27,82 & 23,89 & 20,23 & 6,06 \\
\hline A20 & 1,35 & 2,65 & 1,46 & 1,69 & 1,24 & 1,5 & 0,75 & 1,9 & 0,97 & 1,71 & 0,93 & 0,91 & 0,83 & 1,03 & 1,18 & 1,2 & 0 \\
\hline$A 21$ & 0,13 & 0,29 & 0,18 & 0,17 & 0,15 & 0,11 & 0,12 & 0,19 & 0,14 & 0,21 & 0,14 & 0,1 & 0,1 & 0,19 & 0,15 & 0,12 & 0 \\
\hline$A 22$ & 32,18 & 14,1 & 21,53 & 24,05 & 15,5 & 9,18 & 13,81 & 31,08 & 11,62 & 24,9 & 11,62 & 12,45 & 0,27 & 10,62 & 26,14 & 13,72 & 0 \\
\hline A23 & 2,07 & 1,23 & 0,87 & 1,61 & 2,77 & 2,9 & 5,02 & 6,49 & 23,56 & 24,05 & 1,27 & 1,24 & 3,89 & 13,53 & 17,01 & 3,27 & 33,33 \\
\hline A26 & 25,42 & 27,6 & 14,4 & 21,68 & 17,2 & 33,08 & 31,96 & 21,53 & 27,06 & 31,3 & 27,25 & 16,2 & 9,77 & 14,81 & 34,01 & 59,63 & 0 \\
\hline A28 & 49,8 & 65,3 & 66,63 & 35,95 & 76 & 36,2 & 46,14 & 98,91 & 51,91 & 84,34 & 82,03 & 40,45 & 26,69 & 75,48 & 24,56 & 51,56 & 0 \\
\hline A31 & 3,81 & 3,94 & 3,05 & 1,8 & 4,28 & 6,53 & 5,13 & 7,1 & 2,48 & 5,38 & 5,02 & 3,34 & 2,92 & 3,11 & 6,1 & 3,29 & 0 \\
\hline A35 & 2,26 & 4,78 & 1,57 & 2,05 & 1,31 & 2,82 & 1,45 & 1,98 & 2,04 & 3,01 & 3,16 & 1,75 & 1,84 & 1,83 & 2,75 & 1,52 & 24,24 \\
\hline A36 & 0,63 & 0,65 & 0,3 & 0,36 & 0,35 & 0,78 & 0,62 & 0,49 & 0,61 & 0,85 & 0,54 & 0,32 & 0,34 & 0,4 & 0,71 & 0,44 & 0 \\
\hline A37 & 16,66 & 21,4 & 13,25 & 15,43 & 11,9 & 17,36 & 14,6 & 17,61 & 15,01 & 25,25 & 17,61 & 11,07 & 12,62 & 10,47 & 16,2 & 15,54 & 3,03 \\
\hline A40 & 0,47 & 0,52 & 0,13 & 0,16 & 0,2 & 0,38 & 0,26 & 0,25 & 0,26 & 0,47 & 0,2 & 0,16 & 0,25 & 0,26 & 0,31 & 31,08 & 0 \\
\hline A41 & 4,78 & 5,85 & 2,39 & 2,65 & 3,53 & 9,05 & 3,86 & 4,65 & 3,13 & 8,33 & 5,53 & 3,5 & 5,65 & 4,62 & 4,99 & 4,72 & 0 \\
\hline A42 & 18,87 & 17,6 & 8,33 & 14,2 & 13,1 & 33,08 & 13,25 & 10,76 & 13,34 & 25,96 & 18,1 & 10,76 & 8,39 & 11,62 & 16,89 & 20,51 & 75,76 \\
\hline A43 & 32,86 & 33,8 & 15,12 & 17,13 & 15,2 & 32,63 & 13,53 & 9,44 & 36,2 & 0,28 & 17,61 & 15,01 & 13,07 & 18,61 & 24,73 & 21,38 & 60,61 \\
\hline A44 & 13,72 & 12,1 & 6,58 & 8,68 & 10,6 & 12,89 & 12,03 & 10,84 & 9,7 & 11,54 & 8,74 & 10,69 & 5,31 & 9,11 & 7,93 & 7,51 & 60,61 \\
\hline A46 & 0,65 & 1,05 & 0,48 & 0,59 & 0,5 & 0,79 & 0,6 & 0,56 & 0,56 & 1,49 & 1 & 1,18 & 0,39 & 0,77 & 0,96 & 0,66 & 81,82 \\
\hline A49 & 0,21 & 0,28 & 0,13 & 0,23 & 0,63 & 0,5 & 0,26 & 0,31 & 0,41 & 0,74 & 0,43 & 0,14 & 0,45 & 0,48 & 0,4 & 0,19 & 51,52 \\
\hline A50 & 17,36 & 19,3 & 8,21 & 12,8 & 10,5 & 19,54 & 10,25 & 11,54 & 14,5 & 30,66 & 14,91 & 12,71 & 5,69 & 8,68 & 24,05 & 13,62 & 30,3 \\
\hline A51 & 0,26 & 0,28 & 0,15 & 0,19 & 0,16 & 0,3 & 0,15 & 0,26 & 0,24 & 0,55 & 0,23 & 0,14 & 0,16 & 0,13 & 0,28 & 0,38 & 30,3 \\
\hline A52 & 0,12 & 0,26 & 0,17 & 0,16 & 0,14 & 0,11 & 0,17 & 0,17 & 0,13 & 0,33 & 0,21 & 0,31 & 0,17 & 0,14 & 0,1 & 0,15 & 57,58 \\
\hline
\end{tabular}

*Porcentagem de grãos em uma amostra dos quais foram isolados $F$. verticillioides 
Tabela B.11. Expressão gênica relativa das amostras da coleta 4 que expressaram todo o cluster FUM estudado em relação à amostra calibradora (linha assinalada em cinza) e a porcentagem de contaminação por $F$. verticillioides nas respectivas amostras.

\begin{tabular}{|c|c|c|c|c|c|c|c|c|c|c|c|c|c|c|c|c|c|}
\hline Coleta 4 & $\begin{array}{c}\text { FUM } \\
1\end{array}$ & $\begin{array}{c}\text { FUM } \\
2\end{array}$ & $\begin{array}{c}\text { FUM } \\
6\end{array}$ & $\begin{array}{c}\text { FUM } \\
7\end{array}$ & $\begin{array}{c}\text { FUM } \\
8\end{array}$ & $\begin{array}{c}\text { FUM } \\
9\end{array}$ & $\begin{array}{c}\text { FUM } \\
10\end{array}$ & $\begin{array}{c}\text { FUM } \\
11\end{array}$ & $\begin{array}{c}\text { FUM } \\
13\end{array}$ & $\begin{array}{c}\text { FUM } \\
14\end{array}$ & $\begin{array}{c}\text { FUM } \\
15\end{array}$ & $\begin{array}{c}\text { FUM } \\
16\end{array}$ & $\begin{array}{c}\text { FUM } \\
17\end{array}$ & $\begin{array}{c}\text { FUM } \\
18\end{array}$ & $\begin{array}{c}\text { FUM } \\
19\end{array}$ & $\begin{array}{c}\text { FUM } \\
21\end{array}$ & $\begin{array}{l}\text { Cont. } \\
\text { F.v. (\%) }\end{array}$ \\
\hline A3 & 2,25 & 1,84 & 1,09 & 2,6 & 2,49 & 1,02 & 2,19 & 1,32 & 2,94 & 0,43 & 2,77 & 1,2 & 2,16 & 0,81 & 1,09 & 1,41 & 15,15 \\
\hline A4 & 4,56 & 4,34 & 2,16 & 5,13 & 5,97 & 1,92 & 4,92 & 2,51 & 3,38 & 0,18 & 5,31 & 1,85 & 2,69 & 2,16 & 1,52 & 2,25 & 39,4 \\
\hline A14 & 0,67 & 0,75 & 0,61 & 0,98 & 0,87 & 0,8 & 1,29 & 0,11 & 0,75 & 1,19 & 1,25 & 0,47 & 0,82 & 0,38 & 0,87 & 0,86 & 3,03 \\
\hline A15 & 8,21 & 8,1 & 4,19 & 9,05 & 7,66 & 2,49 & 10,47 & 6,67 & 4,99 & 14,7 & 10,33 & 17,49 & 6,67 & 2,79 & 5,31 & 8,56 & 18,18 \\
\hline A16 & 0,34 & 0,4 & 0,68 & 1,12 & 0,5 & 0,4 & 0,68 & 0,29 & 0,5 & 1,02 & 0,38 & 0,39 & 0,33 & 0,48 & 0,43 & 0,4 & 33,33 \\
\hline A18 & 16,09 & 11 & 11,3 & 19,4 & 21,4 & 11,3 & 19,13 & 9,18 & 17,98 & 25,78 & 20,09 & 8,16 & 12,89 & 8,74 & 7,88 & 8,04 & 42,42 \\
\hline A22 & 18,1 & 17 & 11,54 & 13,16 & 19,7 & 13,44 & 14,6 & 14,81 & 15,01 & 30,44 & 18,61 & 8,04 & 10,25 & 16,09 & 16,2 & 11,62 & 0 \\
\hline A28 & 3,89 & 4,14 & 2,77 & 6,49 & 6,91 & 1,38 & 5,89 & 3,34 & 3,73 & 11,7 & 5,77 & 3,97 & 0,17 & 5,09 & 3,99 & 4,49 & 18,18 \\
\hline A43 & 1,0 & 1,0 & 1,0 & 1,0 & 1,0 & 1,0 & 1,0 & 1,0 & 1,0 & 1,0 & 1,0 & 1,0 & 1,0 & 1,0 & 1,0 & 1,0 & 66,67 \\
\hline A44 & 17,01 & 9,7 & 8,1 & 20,94 & 22,4 & 9,84 & 15,65 & 10,33 & 13,53 & 43,96 & 20,37 & 7,93 & 14,91 & 9,18 & 16,2 & 20,94 & 81,82 \\
\hline A46 & 0,12 & 0,11 & 0,14 & 0,2 & 0,19 & 0,11 & 0,24 & 0,1 & 0,2 & 0,32 & 0,45 & 0,15 & 0,11 & 0,16 & 0,19 & 0,17 & 33,33 \\
\hline A47 & 0,1 & 0,1 & 0,18 & 0,19 & 0,16 & 0,1 & 0,23 & 0,1 & 0,11 & 0,13 & 0,14 & 0,12 & 0,15 & 0,14 & 0,1 & 0,11 & 78,79 \\
\hline A49 & 28,8 & 25,6 & 1,67 & 32,63 & 37,2 & 15,33 & 27,63 & 21,08 & 25,07 & 0,1 & 9,37 & 1,45 & 4,62 & 12,89 & 8,5 & 16,66 & 75,75 \\
\hline A50 & 0,73 & 0,95 & 0,76 & 0,77 & 1,18 & 0,89 & 1,74 & 0,99 & 0,94 & 2,03 & 0,94 & 0,49 & 0,91 & 0,52 & 0,88 & 0,16 & 51,52 \\
\hline A51 & 2,1 & 1,79 & 0,98 & 2,48 & 2,28 & 0,54 & 3,11 & 1,55 & 1,5 & 4,19 & 1,97 & 0,91 & 1,12 & 0,67 & 0,96 & 1,22 & 72,73 \\
\hline A52 & 14,81 & 22,9 & 0,7 & 46,14 & 18,4 & 0,21 & 32,4 & 19,13 & 11,78 & 0,16 & 9,11 & 0,16 & 8,44 & 10,76 & 8,8 & 7,72 & 78,79 \\
\hline
\end{tabular}

*Porcentagem de grãos em uma amostra dos quais foram isolados $F$. verticillioides

Tabela B.12. Expressão gênica relativa das amostras da coleta 5 que expressaram todo o cluster FUM estudado em relação à amostra calibradora (linha assinalada em cinza) e a porcentagem de contaminação por $F$. verticillioides nas respectivas amostras.

\begin{tabular}{|c|c|c|c|c|c|c|c|c|c|c|c|c|c|c|c|c|c|}
\hline coleta 5 & $\begin{array}{c}\text { FUM } \\
1\end{array}$ & $\begin{array}{c}\text { FUM } \\
2\end{array}$ & $\begin{array}{c}\text { FUM } \\
6\end{array}$ & $\begin{array}{c}\text { FUM } \\
7\end{array}$ & $\begin{array}{c}\text { FUM } \\
8\end{array}$ & $\begin{array}{c}\text { FUM } \\
9\end{array}$ & $\begin{array}{c}\text { FUM } \\
10\end{array}$ & $\begin{array}{c}\text { FUM } \\
11\end{array}$ & $\begin{array}{c}\text { FUM } \\
13\end{array}$ & $\begin{array}{c}\text { FUM } \\
14\end{array}$ & $\begin{array}{c}\text { FUM } \\
15\end{array}$ & $\begin{array}{c}\text { FUM } \\
16\end{array}$ & $\begin{array}{c}\text { FUM } \\
17\end{array}$ & $\begin{array}{c}\text { FUM } \\
18\end{array}$ & $\begin{array}{c}\text { FUM } \\
19\end{array}$ & $\begin{array}{c}\text { FUM } \\
21\end{array}$ & $\begin{array}{c}\text { Cont. } \\
\text { F.v. (\%) }\end{array}$ \\
\hline $\mathrm{A} 1$ & 1,0 & 1,0 & 1,0 & 1,0 & 1,0 & 1,0 & 1,0 & 1,0 & 1,0 & 1,0 & 1,0 & 1,0 & 1,0 & 1,0 & 1,0 & 1,0 & 93,94 \\
\hline A8 & 2,73 & 1,47 & 1,2 & 2,46 & 1,26 & 2,62 & 1,88 & 1,88 & 2,16 & 5,06 & 0,24 & 1,09 & 1,73 & 1,38 & 1,76 & 2,62 & 75,76 \\
\hline A11 & 4,05 & 3,38 & 1,6 & 3,34 & 3,2 & 6,1 & 5,89 & 2,75 & 2,62 & 4,75 & 2,55 & 0,98 & 4,72 & 4,05 & 3,58 & 3,91 & 96,7 \\
\hline A15 & 0,11 & 0,1 & 0,11 & 0,14 & 0,1 & 0,16 & 0,17 & 0,13 & 0,1 & 0,17 & 0,12 & 0,11 & 0,16 & 0,14 & 0,12 & 0,12 & 51,51 \\
\hline A16 & 1,51 & 1,38 & 0,71 & 1,4 & 0,82 & 1,04 & 1,58 & 1,16 & 1,59 & 2,62 & 1,06 & 0,49 & 1,75 & 1,26 & 0,1 & 0,76 & 42,42 \\
\hline A18 & 0,5 & 0,36 & 0,16 & 0,4 & 0,26 & 0,12 & 0,59 & 0,3 & 0,23 & 0,61 & 0,18 & 0,18 & 0,35 & 0,33 & 0,33 & 0,24 & 27,27 \\
\hline A25 & 32,63 & 15,1 & 14,2 & 26,32 & 24,6 & 12,71 & 37,22 & 22,6 & 23,23 & 0,18 & 8,56 & 2,71 & 28,4 & 25,42 & 17,24 & 10,18 & 60,6 \\
\hline A29 & 12,28 & 8,39 & 3,89 & 13,34 & 9,37 & 6,49 & 13,62 & 7,56 & 7,99 & 1,62 & 5,61 & 1,29 & 12,45 & 5,93 & 8,04 & 5,57 & 39,39 \\
\hline A38 & 2,79 & 1,74 & 0,25 & 4,69 & 9,11 & 3,07 & 5,77 & 3,2 & 2,01 & 0,21 & 1,5 & 0,24 & 2,43 & 49,46 & 0,1 & 1,34 & 0 \\
\hline A39 & 0,1 & 0,13 & 0,12 & 0,24 & 0,19 & 0,29 & 0,21 & 0,11 & 0,13 & 0,13 & 0,14 & 0,12 & 0,28 & 0,2 & 0,31 & 0,26 & 36,36 \\
\hline A47 & 2,77 & 1,35 & 1,05 & 2,67 & 2,38 & 1,62 & 2,53 & 1,36 & 1,76 & 0,16 & 2,2 & 0,89 & 1,89 & 1,85 & 1,75 & 2,64 & 60,6 \\
\hline A52 & 0,69 & 0,68 & 0,38 & 0,63 & 0,66 & 0,66 & 1,94 & 0,15 & 0,91 & 1,45 & 0,73 & 0,4 & 1,06 & 0,82 & 0,78 & 1,09 & 87,78 \\
\hline
\end{tabular}

*Porcentagem de grãos em uma amostra dos quais foram isolados $F$. verticillioides 
Tabela B.13. Expressão gênica relativa das amostras da coleta 6 que expressaram todo o cluster FUM estudado em relação à amostra calibradora (linha assinalada em cinza) e a porcentagem de contaminação por $F$. verticillioides nas respectivas amostras.

\begin{tabular}{|c|c|c|c|c|c|c|c|c|c|c|c|c|c|c|c|c|c|}
\hline Coleta 6 & $\begin{array}{c}\text { FUM } \\
1\end{array}$ & $\begin{array}{c}\text { FUM } \\
2\end{array}$ & $\begin{array}{c}\text { FUM } \\
6\end{array}$ & $\begin{array}{c}\text { FUM } \\
7\end{array}$ & $\begin{array}{c}\text { FUM } \\
8\end{array}$ & $\begin{array}{c}\text { FUM } \\
9\end{array}$ & $\begin{array}{c}\text { FUM } \\
10\end{array}$ & $\begin{array}{c}\text { FUM } \\
11\end{array}$ & $\begin{array}{c}\text { FUM } \\
13\end{array}$ & $\begin{array}{c}\text { FUM } \\
14\end{array}$ & $\begin{array}{c}\text { FUM } \\
15\end{array}$ & $\begin{array}{c}\text { FUM } \\
16\end{array}$ & $\begin{array}{c}\text { FUM } \\
17\end{array}$ & $\begin{array}{c}\text { FUM } \\
18\end{array}$ & $\begin{array}{c}\text { FUM } \\
19\end{array}$ & $\begin{array}{c}\text { FUM } \\
21\end{array}$ & $\begin{array}{c}\text { Cont. } \\
\text { F.v. (\%) }\end{array}$ \\
\hline A5 & 1,31 & 0,85 & 0,42 & 0,98 & 0,87 & 1,19 & 0,96 & 0,78 & 0,84 & 1,98 & 1,11 & 0,41 & 1,4 & 0,34 & 1,05 & 0,98 & 39,39 \\
\hline A16 & 1,0 & 1,0 & 1,0 & 1,0 & 1,0 & 1,0 & 1,0 & 1,0 & 1,0 & 1,0 & 1,0 & 1,0 & 1,0 & 1,0 & 1,0 & 1,0 & 87,88 \\
\hline A17 & 1,27 & 1,03 & 0,6 & 0,87 & 1,3 & 1,19 & 1,26 & 1,67 & 0,97 & 1,85 & 1,76 & 0,61 & 1,41 & 1,15 & 1,36 & 1,18 & 63,64 \\
\hline A20 & 2,79 & 1,2 & 0,51 & 2,38 & 3,07 & 0,1 & 2,65 & 2,44 & 1,66 & 4,62 & 2,94 & 0,81 & 1,76 & 1,15 & 1,21 & 1,06 & 78,79 \\
\hline A23 & 4,75 & 3,13 & 2,25 & 3,83 & 5,09 & 5,57 & 3,68 & 3,18 & 3,24 & 7,3 & 2,94 & 2,53 & 4,85 & 3,38 & 4,92 & 4,53 & 21,21 \\
\hline A25 & 23,72 & 20,9 & 19 & 35,21 & 48,1 & 5,57 & 27,63 & 43,05 & 34,97 & 0,86 & 15,65 & 20,09 & 25,42 & 10,84 & 20,65 & 15,76 & 78,79 \\
\hline A26 & 20,23 & 32,9 & 48,1 & 0,38 & 54,9 & 9,5 & 53,37 & 38,8 & 36,2 & 10,62 & 40,45 & 29,82 & 32,86 & 13,53 & 57,21 & 26,14 & 100 \\
\hline A39 & 15,33 & 6,44 & 6,05 & 8,1 & 8,74 & 34,25 & 14,2 & 14,6 & 11,7 & 0,21 & 10,69 & 2,1 & 4,05 & 3,29 & 9,24 & 14,1 & 100 \\
\hline A41 & 0,21 & 0,14 & 0,15 & 0,19 & 0,25 & 0,31 & 0,11 & 0,2 & 0,3 & 0,29 & 0,34 & 0,2 & 0,22 & 0,11 & 0,23 & 0,24 & 72,73 \\
\hline A48 & 0,12 & 0,13 & 0,11 & 0,1 & 0,1 & 0,18 & 0,1 & 0,16 & 0,11 & 0,19 & 0,18 & 0,12 & 0,2 & 0,11 & 0,15 & 0,13 & 57,58 \\
\hline A50 & 0,19 & 0,1 & 0,11 & 0,14 & 0,19 & 0,12 & 0,1 & 0,12 & 0,13 & 0,29 & 0,12 & 0,14 & 0,2 & 0,1 & 0,17 & 0,1 & 100 \\
\hline A52 & 12,71 & 9,05 & 4,95 & 10,25 & 12,1 & 13,62 & 10,84 & 9,44 & 13,34 & 25,25 & 14,6 & 6,49 & 14,3 & 3,43 & 12,54 & 11,22 & 96,97 \\
\hline
\end{tabular}

*Porcentagem de grãos em uma amostra dos quais foram isolados $F$. verticillioides

Tabela B.14. Expressão gênica relativa das amostras da coleta 7 que expressaram todo o cluster FUM estudado em relação à amostra calibradora (linha assinalada em cinza) e a porcentagem de contaminação por $F$. verticillioides nas respectivas amostras.

\begin{tabular}{|c|c|c|c|c|c|c|c|c|c|c|c|c|c|c|c|c|c|}
\hline Coleta 7 & $\begin{array}{c}\text { FUM } \\
1\end{array}$ & $\begin{array}{c}\text { FUM } \\
2\end{array}$ & $\begin{array}{c}\text { FUM } \\
6\end{array}$ & $\begin{array}{c}\text { FUM } \\
7\end{array}$ & $\begin{array}{c}\text { FUM } \\
8\end{array}$ & $\begin{array}{c}\text { FUM } \\
9\end{array}$ & $\begin{array}{c}\text { FUM } \\
10\end{array}$ & $\begin{array}{c}\text { FUM } \\
11\end{array}$ & $\begin{array}{c}\text { FUM } \\
13\end{array}$ & $\begin{array}{c}\text { FUM } \\
14\end{array}$ & $\begin{array}{c}\text { FUM } \\
15\end{array}$ & $\begin{array}{c}\text { FUM } \\
16\end{array}$ & $\begin{array}{c}\text { FUM } \\
17\end{array}$ & $\begin{array}{c}\text { FUM } \\
18\end{array}$ & $\begin{array}{c}\text { FUM } \\
19\end{array}$ & $\begin{array}{c}\text { FUM } \\
21\end{array}$ & $\begin{array}{c}\text { Cont. } \\
\text { F.v. (\%) }\end{array}$ \\
\hline A4 & 0,11 & 0,25 & 1,73 & 0,12 & 0,15 & 0,13 & 0,15 & 0,12 & 0,11 & 0,16 & 0,13 & 0,11 & 0,1 & 0,19 & 0,16 & 0,12 & 60,61 \\
\hline A6 & 0,35 & 0,21 & 0,71 & 0,3 & 0,38 & 0,37 & 0,23 & 0,29 & 0,35 & 0,42 & 0,39 & 0,33 & 0,33 & 0,59 & 0,5 & 0,26 & 66,67 \\
\hline A7 & 0,16 & 0,21 & 1,97 & 0,13 & 0,14 & 0,19 & 0,11 & 0,12 & 0,11 & 0,21 & 0,12 & 0,11 & 0,13 & 0,23 & 0,17 & 0,08 & 100 \\
\hline A8 & 0,79 & 0,47 & 0,45 & 0,68 & 0,53 & 0,77 & 0,6 & 0,1 & 0,65 & 1,28 & 0,71 & 0,37 & 0,48 & 0,35 & 0,76 & 0,43 & 30,3 \\
\hline A9 & 11,54 & 7,2 & 0,61 & 5,73 & 6,31 & 0,5 & 10,54 & 9,37 & 27,25 & 22,44 & 7,4 & 0,13 & 8,74 & 8,21 & 5,27 & 2,6 & 100 \\
\hline A10 & 0,31 & 0,18 & 1,19 & 0,26 & 0,23 & 0,24 & 0,24 & 0,17 & 0,2 & 0,7 & 0,25 & 0,25 & 0,26 & 0,42 & 0,38 & 0,24 & 30,3 \\
\hline A16 & 0,76 & 0,5 & 0,43 & 0,44 & 0,64 & 0,97 & 0,75 & 0,55 & 0,75 & 1,15 & 0,6 & 0,4 & 0,47 & 0,86 & 0,75 & 0,59 & 78,79 \\
\hline A18 & 14,3 & 10,3 & 5,93 & 6,81 & 11,8 & 5,23 & 7,93 & 8,8 & 7,61 & 0,35 & 12,54 & 5,23 & 10,99 & 6,96 & 14,3 & 7,61 & 57,58 \\
\hline A28 & 64,36 & 63,5 & 42,76 & 59,63 & 75 & 58,41 & 50,5 & 75,48 & 46,46 & 0,17 & 78,69 & 30,66 & 38,27 & 58,41 & 18,87 & 38,53 & 60,61 \\
\hline A29 & 58,81 & 2,88 & 4,46 & 39,62 & 14,7 & 4,4 & 26,5 & 41,3 & 108,2 & 65,71 & 24,39 & 0,14 & 0,54 & 11,7 & 16,77 & 32,4 & 100 \\
\hline A30 & 6,58 & 4,75 & 3,86 & 5,57 & 4,69 & 4,25 & 5,73 & 4,05 & 3,53 & 0,15 & 4,85 & 3,11 & 3,99 & 3,03 & 7,1 & 2,94 & 54,55 \\
\hline A33 & 8,93 & 9,84 & 4,65 & 8,5 & 8,39 & 13,16 & 6,86 & 7,3 & 9,5 & 26,5 & 7,93 & 4,05 & 9,9 & 7,4 & 15,01 & 7,99 & 90,91 \\
\hline A35 & 0,16 & 0,28 & 0,64 & 0,14 & 0,21 & 0,14 & 0,14 & 0,2 & 0,22 & 0,56 & 0,23 & 0,14 & 0,16 & 0,12 & 0,21 & 0,15 & 36,36 \\
\hline A36 & 0,19 & 0,25 & 0,51 & 0,13 & 0,17 & 0,2 & 0,14 & 0,17 & 0,12 & 0,39 & 0,18 & 0,16 & 0,14 & 0,23 & 0,07 & 0,14 & 27,27 \\
\hline A38 & 5,57 & 4,02 & 0,76 & 1,34 & 1,55 & 4,53 & 2,17 & 1,06 & 2,23 & 0,11 & 7,25 & 0,1 & 6,63 & 1,73 & 0,16 & 1,14 & 90,91 \\
\hline A42 & 20,23 & 13,7 & 1,34 & 16,66 & 0,86 & 0,45 & 7,2 & 9,63 & 3,24 & 0,29 & 21,68 & 0,29 & 7,2 & 0,74 & 12,89 & 6,36 & 18,18 \\
\hline A44 & 9,9 & 10,2 & 5,97 & 8,1 & 11,9 & 17,49 & 11,3 & 9,18 & 7,51 & 27,25 & 10,84 & 4,46 & 7,56 & 11,22 & 14,3 & 9,31 & 12,12 \\
\hline A47 & 1,0 & 1,0 & 1,0 & 1,0 & 1,0 & 1,0 & 1,0 & 1,0 & 1,0 & 1,0 & 1,0 & 1,0 & 1,0 & 1,0 & 1,0 & 1,0 & 72,73 \\
\hline A48 & 0,4 & 0,35 & 0,42 & 0,28 & 0,29 & 0,46 & 0,27 & 0,24 & 0,23 & 0,52 & 0,18 & 0,26 & 0,25 & 0,39 & 0,36 & 0,29 & 42,42 \\
\hline A51 & 4,92 & 3,22 & 2,03 & 3,55 & 4,59 & 0,1 & 2,97 & 2,67 & 3,65 & 9,05 & 2,97 & 1,73 & 2,84 & 4,82 & 5,93 & 3,2 & 63,64 \\
\hline
\end{tabular}

*Porcentagem de grãos em uma amostra dos quais foram isolados $F$. verticillioides 